Kelly Sabino

\title{
Arsenal \\ um bando de ideias sobre arte na educação
}

Universidade de São Paulo

Faculdade de Educação

2015 

Kelly Sabino

\section{Arsenal \\ um bando de ideias sobre arte na educação}

Dissertação apresentada à Faculdade de Educação como requisito
parcial para obtenção de título de Mestre em Educação.

Área de Concentração: Filosofia e Educação

Orientação: Prof. Dr. Celso F. Favaretto

Universidade de São Paulo

Faculdade de Educação

2015 
Autorizo a reprodução e divulgação total ou parcial deste trabalho por qualquer meio convencional ou eletrônico, para fins de estudo e pesquisa, desde que citada a fonte.

Catalogação na Publicação

Serviço de Biblioteca e Documentação

Faculdade de Educação da Universidade de São Paulo

Sabino, Kelly

Arsenal: um bando de ideias sobre arte na educação / Kelly Sabino; orientação Celso F. Favaretto. São Paulo: s. n, 2015. 248 p. ; ils.

em Educação.

Dissertação (Mestrado - Programa de Pós-Graduação

Área de Concentração: Filosofia e Educação) - - Faculdade de Educação da Universidade de São Paulo.

1. Arte 2. Educação 3. Criação 4. Docência 5. Arte contemporânea 6. Deleuze, Gilles I. Favaretto, Celso F., orient. 
SABINO, Kelly Cristine. Arsenal: um bando de ideias sobre arte na educação. Dissertação (Mestrado). Programa de Pós-Graduação em Educação, Linha de Pesquisa Filosofia e Educação, da Faculdade de Educação da Universidade de São Paulo, 2015.

Aprovada em:

Banca Examinadora:

Prof. Dr. Instituição

Julgamento: Assinatura:

Prof. Dr. Instituição

Julgamento: Assinatura:

Prof. Dr. Instituição

Julgamento: Assinatura: 

Para Dora e Gil, pelas vidas que brotam a cada olhar Para Rica, pela cumplicidade 



\section{Agradecimentos}

À Rose e Valdir, por todo amor e prontidão.

Ao Prof. Celso, pela confiança, compromisso e generosidade.

Ao Prof. Julio, pelas poucas e certeiras palavras.

Ao Rica, por todos os gestos e afetos, pela parceria de tantas criações.

À minha amiga e especial revisora dessas palavras Marcela Vieira.

Aos meus amigos da Escola de Aplicação, com quem posso remoçar em esperanças: Adriana Sesti, Adriana Oliveira, Ana Lúcia Cruz, Claudia Viégas, Ernani Nagy, Jussara Vaz, Kamila Rumi, Léo Roque, Lindy Moretti, Maíra Batistoni, Milena Bushatsky, Patrícia Martins, Roberto Ravena, Sahsha Dellatorre.

Às minhas amigas-irmãs: Ana Luiza Guarnieri, Bruna Lima, Diana Sampaio, Florence Rodrigues, Isabela Valent, Julia Santos, Julia Pupo. Às minhas irmãs-amigas: Karla Sabino, Flávia Sabino.

À minha família expandida: Joviano Leite, Ruth Sabino, Barbara Mollan, Renata Saito, Flávio Galvão, Paula Saito, Pedro Saito, Raoni Garcia, Rodrigo Carneiro.

Aos amigos, alunos, professores que, em bandos, me turbilhonaram com movimentos, afetos, pensamentos, vida e arte: Damyler Cunha, Fabiana Deus, Denise Passos, Janete Salim, Ana Paula Chaves, Daniel Araújo, Daniel Favaretto, Cayo Honorato, Viviane Pinto, Theo Craveiro, Bruno Nadai, Raoni Paniago, Viviane Domingues, Diogo de Moraes, Fábio Zanoni, Jorge Menna Barreto, Marcelo D'Salete, Danilo Moreno, Paulo Leal, Paula Sanches, Erika Miaciro, Reinaldo, Anderson, Christiana Moraes, Mariangela Serri, Sumaya Mattar. 

SABINO, Kelly Cristine. Arsenal: um bando de ideias sobre arte na educação. Dissertação (Mestrado). Orientação de Celso Fernando Favaretto; Revisão Marcela Vieira e Ricardo Mollan Saito. Programa de Pós-Graduação em Educação, Linha de Pesquisa Filosofia e Educação, da Faculdade de Educação da Universidade de São Paulo, 2015.

\section{RESUMO}

Arsenal é um depósito de ideias advindas da sala de aula, da arte dita contemporânea e da filosofia de Deleuze e Guattari. Composto como um abecedário, trata-se de um dicionário nascido do embate entre o campo da arte-educação, aquilo que dizem os alunos e alguns artistas, misturado e transformado à moda da filosofia da diferença. A arte contemporânea interessa a esta pesquisa pelo embaralhamento que ela causa nas formas canonizadas e estáveis de se entender e receber arte, por intuir que tais operações artísticas podem contribuir para inserções da arte no ambiente escolar por meio da invenção e da potência. As experiências de mergulho na vida-aula, mais do que relatos do "bem-sucedido", operam como disparos daquilo que gera o desconforto e o desentendimento, por entender com Barthes que "a escritura começa onde a fala torna-se impossível". É, portanto, na negociação entre-margens da pesquisa e da prática que se situa este trabalho, acondicionando uma necessidade de encontros: arte, educação, filosofia e os tantos atravessamentos trazidos pela sala de aula. Com este Arsenal busca-se identificar uma suposta "cultura escolar em torno da arte", tensionando a posição por ela ocupada na educação, ao mesmo tempo que propondo-se a inscrevê-la no cotidiano escolar, para além do binômio metodologia-conhecimento. Arsenal apresenta em vinte e três verbetes maneiras de encarar a sala de aula, a arte, os alunos e a escola como raridades, ao modo de Foucault, para que as coisas e as palavras não estejam diretamente relacionadas a verdades inquestionáveis, travando um embate por uma educação com mais vitalidade, onde a diferença e a criação possam brotar naquele espaço tão árido e pisoteado chamado escola.

Palavras-chave: arte; educação; Deleuze; criação; docência; arte contemporânea; 

SABINO, Kelly Cristine. Arsenal: a bunch of ideas on art in education. Under the tutorship of Celso Fernando Favaretto; Reviewed by Marcela Vieira and Ricardo Mollan Saito. Thesis (MS). Postgraduate Program in Education, Research Line Philosophy and Education, Faculty of Education, University of São Paulo, in 2015.

\begin{abstract}
Arsenal is a repository of ideas collected from the classroom, from so called contemporary art and from Deleuze and Guattari's philosophy. Compiled as an alphabet, it is a dictionary born of the clash between the field of art education and what students and some artists say, mixed and transformed in the fashion of the philosophy of difference. Contemporary art is of interest to this research because of the scrambling it causes to the canonized and stable ways of understanding and receiving art, in the belief that such operations can contribute to art inserts in the school environment through invention and power. Life experiences gathered in the classroom, rather than stories of success", operate as shots of what generates discomfort and misunderstanding, understanding with Barthes that "writing begins where speech becomes impossible." It is therefore in the negotiation between the margins of research and practice that this work is situated, accomodating a need for a place where art, education, philosophy and so many crossings brought to the classroom meet. Arsenal seeks to identify an alleged "school culture around the arts", tensing the position this culture holds in education, while proposing to inscribe it into everyday school life, to a point beyond the methodology-knowledge binomial. Arsenal presents through twenty-three entries ways to see the classroom, art, students and the school as rarities, in the Foucault mode, so that things and words are not directly related to unquestionable truths, waging a struggle for an education with more vitality and allowing difference and creation to spring up in that arid and trampled place called school.
\end{abstract}

Keywords: art; education; Deleuze; creation; teaching; contemporary art; 



\section{ÍWDICE}

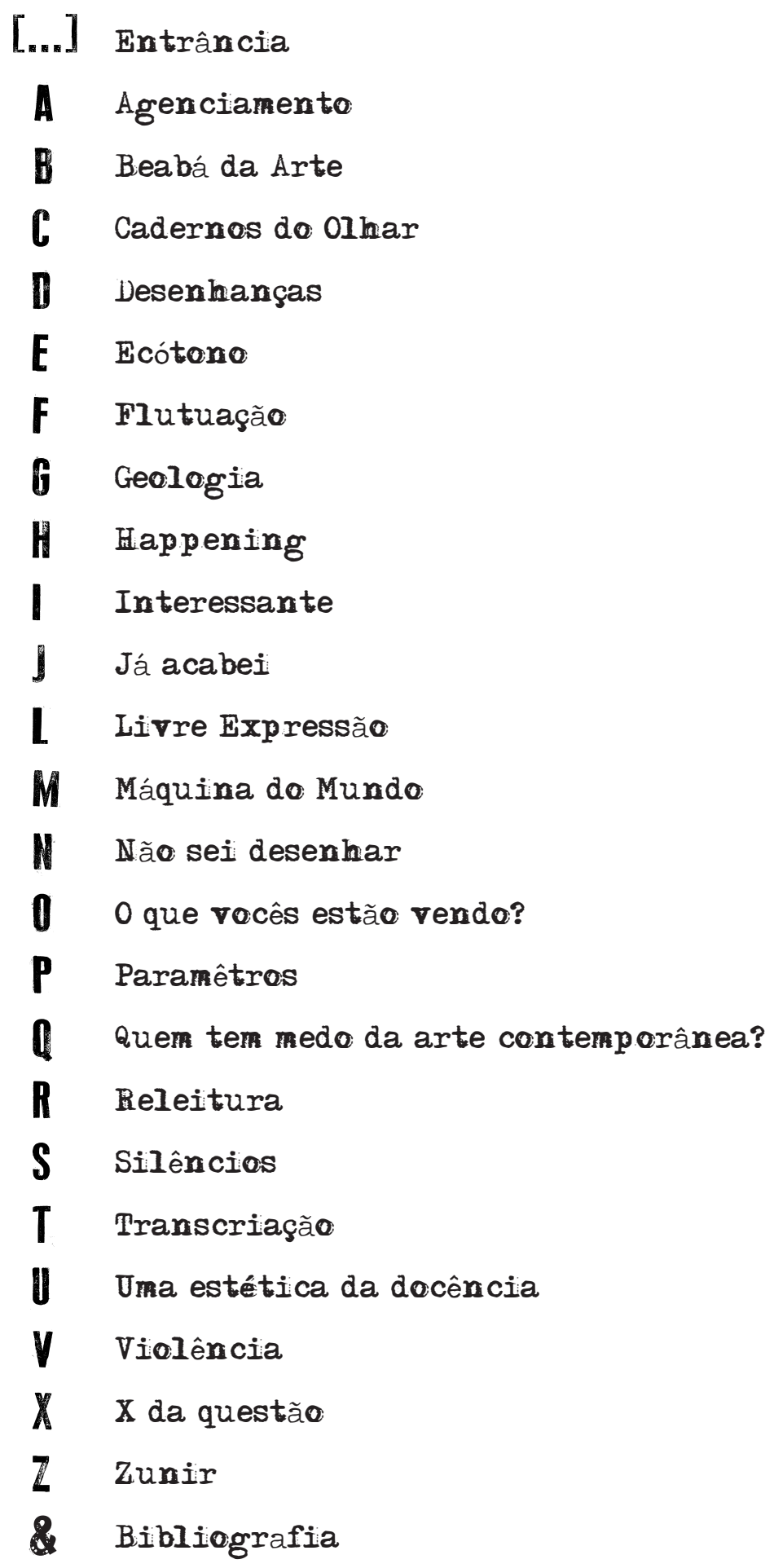

99

29

37

45

51

59

69

79

91

99

107

115

125

135

143

153

i63

171

181

191

201

211

219

227

239 


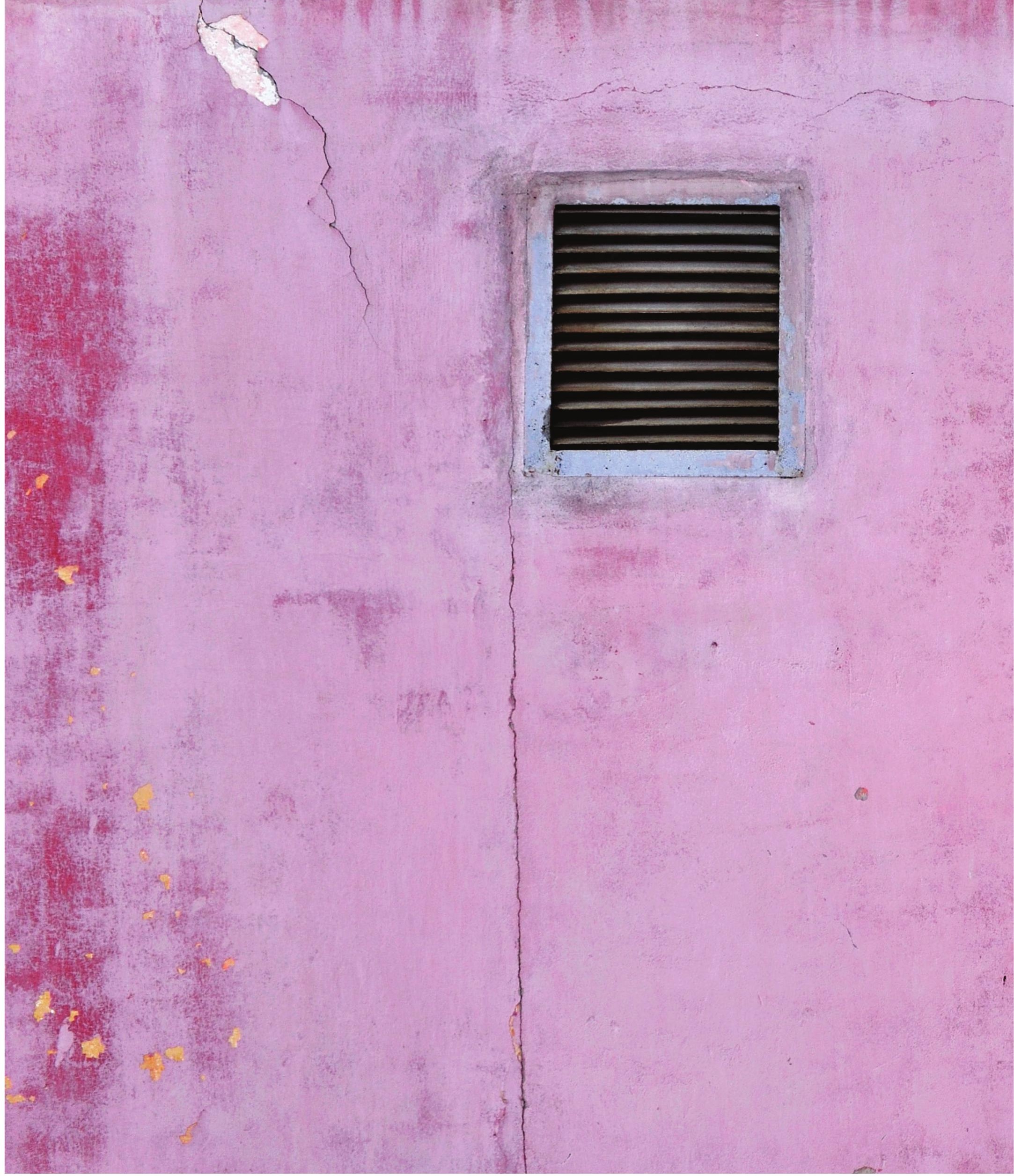




"Nada de ideias justas, apenas ideias. Apenas ideias, é o encontro, o devir, o roubo e as núpcias, esse "entre-dois" das solidões.

Ser um "bando": os bandos vivem os piores

perigos, reformar os juízes, tribunais, escolas, famílias e conjugalidades, mas o que há de bom em um bando, em princípio, é que cada um cuida de seu próprio negócio encontrando ao mesmo tempo os outros; cada um tira

seu proveito, e que um devir se delineia, um bloco, que já não é de ninguém, mas está "entre" todo mundo, se põe em movimento como um barquinho que crianças largam e perdem e que outros roubam."

Gilles Deleuze

"Não, liberdade eu não queria. Apenas uma saída; à direita, à esquerda, para onde quer que fosse; eu não fazia outras exigências; a saída podia também ser apenas um engano; a exigência era pequena, o engano não seria maior. Ir em frente, ir em frente! Só não ficar parado com os braços levantados, comprimido contra a parede de um

caixote."

Franz Kafka 

Um papel em branco: "O que faz com que eu me mova da margem esquerda à margem direita da página?"1 Vito Acconci, escritor nova-iorquino que deixou a poesia para tornar-se um expoente nome da performance e da arte nas décadas de 1960/70, via o papel como um espaço a ser atravessado. Sua preocupação com a literalidade desse campo foi o que o obrigou a deixar a literatura - ele não imaginava ser possível escrever mais sobre árvores, casas ou pessoas, era preciso que as coisas se tornassem concretas.

No caso desta pesquisa, a negociação está no entre as margens da prática e da reflexão, pois, na insuficiência do papel - assim como crê Acconci -, mergulho na vida-aula e é por faltar respiros que volto à suspensão do estado de palavras, da brancura da folha e do silêncio imprescindíveis à reflexão. "A escritura começa onde a fala torna-se impossível"

Este trabalho se trata, sobretudo, de um experimento irrigado pelo que é vivido em sala, pelo desconforto e pelo desentendimento. Ele é menos uma busca por uma verdade incontornável, e mais uma procura por saciar a ávida necessidade de encontros: arte, educação, filosofia e os tantos atravessamentos que a sala de aula me traz. Esse local de pleno convívio com a matéria-vida que pulsa em cada par de olhos. A que e a quem serve tal pesquisa? Ou, ainda, parafraseando Groys: "Quais esperanças estão ligadas a este projeto?". 3

Ainda que eu não saiba exatamente a resposta, sei que, no limite, busco uma solidão, seja ela reconciliada ou solidária, importante lição do professor, como nos apresenta Deleuze na letra "P" de seu Abecedário; seja a solidão sancionada que, como acredita Groys, procura inevitavelmente um outro, um redirecionamento dos fluxos que circulam em uma pesquisa. Há, sobretudo, a esperança de que o projeto-pesquisa lançado à própria sorte povoe o sertão que existe no hiato entre aquilo que é pressentimento-dúvida e a coisa-normatizada-cotidiano, abrindo, quem sabe, uma "minúscula fenda por onde aquilo que dizemos nos escapa." ${ }^{4}$

\section{Movimento uma matéria}

Sou professora de arte. Diariamente, recebo um molho de chaves e uma sala de aula repleta de olhares examinadores a me perguntar: A que vim? O que "vai ter" hoje? Questões cheias de expectativas. Mútuas.

Em um primeiro momento silencio os gritos surdos dos alunos e imediatamente sou sugada pela espiral da aula e por todas as matérias que nela se movimentam e que não cessam de ultrapassar definitivamente aquilo que se denomina componente curricular "Arte".

Aula é movimento, nos diz mais uma vez Deleuze acerca do contexto do professor. Movimento para além da disciplina arte, ou seja, tudo o que desconheço sobre os diversos elementos colocados ali naquele espaço-tempo centrípeto, pois há muitas camadas em

\footnotetext{
1 ACCONCI, Vito. In: OBRIST, H. U. Hans Ulrich Obrist interviews. 1. Ed. Thomas Boutoux. Ed. Charta, 2003. p. 45 (trad. aut.).

2 BARTHES, R. Escritores, intelectuais, professores. In ensaios. Lisboa: Presenç, 1975. p. 25.

3 GROYS, Boris. A solidão do projeto. tradução Roberto Winter. Disponível em: http://projetosnatemporada.org/ eventos/arte-projeto/groys/solidao-do-projeto/ Acesso em 07/03/2014.

$4 \quad$ FOUCAULT, Michel. Ordem do Discurso. São Paulo: Edições Loyola, 2004. p. 4.
} 
uma aula. Barthes fala que na primeira relação com a sala de aula acreditamos que ensinar é compartilhar um saber, porém "vem em seguida outra, que se ensina o que não se sabe: isso se chama pesquisar". Entretanto, é possível ir além, na "idade de uma outra experiência, a de desaprender, de deixar trabalhar o remanejamento imprevisível que o esquecimento impõe à sedimentação dos saberes, das culturas, das crenças que atravessamos." ${ }^{5}$

Trata-se de questões referentes ao tempo, à experiência, àquilo que não se sabe, mas que quer ser partilhado, que surge da necessidade de habitar outros lugares entre arte e educação. Questões que talvez me levem a confirmar que minha solidão não é só minha; por mais penosa e irrevogável que ela seja, não é privada, e isso ocorre tão somente porque "um criador não é um ser que trabalha pelo prazer. Um criador só faz aquilo de que tem absoluta necessidade. ${ }^{\prime 6} \mathrm{Na}$ solidão, deve haver algo disso que diz respeito a um outro e se endereça a ele. Questão de encontro, ainda que se desconheça seu fim, pois "quando se sabe de antemão onde se vai terminar ou se vai chegar, há uma dimensão da experiência que falta, aquela que consiste precisamente em escrever um livro arriscado de não chegar à parte final." 7

Pois, então, para além da busca pela partilha de uma solidão povoada de inquietações, existe algo da ordem da necessidade, que faz com que todo pesquisador seja capaz de seguir na branquidão do papel - motivo pelo qual a escritura se faz imprescindível. Barthes diria que "porque a escrita descentra a fala, o indivíduo, a pessoa, realiza um trabalho cuja origem é indiscernível"; $;$ e é dessa busca pelo incompossível fruto da escritura que parte essa pesquisa: da vontade de juntar, engendrar formas, frutos dos tantos encontros povoados por uma filosofia, uma arte e uma educação. A ideia, aqui, é traçar um plano, como um organismo formal, dotado de órgãos que lhe confiram uma "anatomia própria" tal como insistia Paul Klee. ${ }^{9}$ Plano a partir do qual e dentro do qual se inscrevem as regras do jogo que é posto. Ou então seguir com Kandinsky, que preferia o termo "composição", algo que se baseia "em ressonâncias múltiplas captadas nas tensões que se estabelecem entre os elementos e o plano original." ${ }^{10}$

Esta pesquisa guarda a ideia de uma composição-plano que traz em si, circunscrito, o desejo de experimentar o que, da arte contemporânea, pode interessar a uma prática de docência em arte a fim de favorecer a invenção na sala de aula.

De que modo as práticas artísticas contemporâneas podem ajudar a inscrever a arte na educação? E como, nós, professores, podemos, a partir de indícios e procedimentos advindos da arte contemporânea, fomentar nossas práticas educativas?

É notável, no contexto contemporâneo, a existência de práticas artísticas que tenham em comum a capacidade de disparar, afetar, remodelar e redistribuir as formas de compreensão a respeito do quê, quando e por quê algo pode ser chamado de arte, ao invés de propor

\footnotetext{
5 BARTHES, Roland. Aula. Trad. Leyla Perrone-Moisés. São Paulo: Cultrix, 1988. p. 45

DELEUZE, Gilles. $O$ ato de criação. Trad. José Marcos Macedo. Em: Folha de São Paulo, Caderno Mais!, 27 de unho de 1999. p. 3

FOUCAULT. Michel. Estética da existência. Disponível em: www.filoesco.unb.br/foucault. Acesso em 13/06/2014. p. 1. BARTHES, Roland. Inéditos, vol. 1 - teoria. S. Paulo: Martins Fontes, 2004. p. 101-2.

KLEE, Paul. In: MANTERO, Ana. Contraponto. Klee e Kandinsky - Diálogos em terra fértil. Revista Philosophica. Disponível: http://www.centrodefilosofia.com/uploads//pdfs/philosophica/19_20/14.pdf. Acesso em 15/04/2014. p. 3.

10 KANDINSKY, Wassily. In: MANTERO, op. cit., p. 4
} 
reafirmações das formas canônicas a respeito do tema. Tais operações podem contribuir muito para as inserções da arte no ambiente escolar por meio da chave da invenção e da potência.

Ainda que sejam muitas as questões a serem investigadas por essa pesquisa, seu objetivo é tensionar a posição que a arte ocupa na educação. Através da escrita e da prática docente, pretende-se propor outros modos de inscrever a arte no cotidiano escolar que não seja pelo binômio metodologia-conhecimento. Seguindo o rastro foucaultiano, a intenção é "abandonar essas sínteses fabricadas, esses agrupamentos que são aceitos antes de qualquer exame, essas ligações cuja validade é admitida de saída; (...) aceitar ter relações apenas, em primeira instância, com uma população de acontecimentos dispersos." ${ }^{11}$

É preciso encarar a sala de aula, a arte, os alunos e a escola como raridades, ainda ao modo de Foucault, para que as coisas e as palavras não estejam diretamente relacionadas a verdades inquestionáveis: "fatos e coisas ditas são raros porque há um vazio em torno deles, já que são possibilidades, múltiplas." ${ }^{12}$

\section{0 procedimento}

"O conflito entre a escritura e a vida, reduzido a tal simplicidade, não pode oferecer nenhum princípio seguro de explicação, inclusive se explicação for aqui apenas o desdobramento de afirmações que se requerem umas às outras para pôr-se à prova, sem limitar-se."13

Nosso procedimento consiste em um experimento que opera em interlocução com referências bibliográficas advindas de áreas pouco confrontadas, ao menos no campo de discussão da arte-educação. Através de contágios entre pensamentos artísticos contemporâneos, filosóficos e da sala de aula, pretende-se propor um outro plano de pensamento, conectando a arte à educação.

Tal experimento, no entanto, ocorrerá no campo da escrita. Ainda que ele seja atravessado pelo vivido em sala de aula, não se trata de um relato pessoal, pois "escrever não é impor uma forma de expressão a uma matéria vivida, mas trata-se de um procedimento informe, de um processo inacabado, de uma passagem de Vida que atravessa o vivível e o vivido." ${ }^{14}$

Por ser alimentado pela experiência de sala de aula, esta pesquisa toma como base, para compor-se em escritura, uma proposta de sala de aula, a qual dei o nome de Caderno do olhar.

Pouco tempo após ter me deparado com as forças, jargões e concepções que envolviam

\footnotetext{
11 FOUCAULT, Michel. Arqueologia das Ciências e História dos Sistemas de Pensamento. Ditos \& Escritos. Vol. II. Rio de janeiro: Forense-Universitária. 2005. p. 65

12 FISCHER, Rosa. Foucault revoluciona a educação? FISCHER, Rosa Maria Bueno. Foucault revoluciona a pesquisa em educação?. Perspectiva, v. 21, n. 2, p. 371-389, 2003. p. 374.

13 BLANCHOT, Maurice. apud. INFORSATO, Erika Alvarez. Desobramento: constelações clínicas e políticas do comum. 2011. Tese de Doutorado. Universidade de São Paulo. p. 15.

14 CORAZZA, Sandra Mara. Contribuições de Deleuze e Guattari para as pesquisas em educação. Revista Digital do LAV, n. 8, p. 125-144, 2012. Disponível em: http://cascavel.cpd.ufsm.br/revistas/ojs-2.2.2/index.php/revislav/article/ view/5298/3225. Acesso em 10/07/2015. p. 15.
} 
as concepções dos meus alunos em torno da aula de arte e, movida pela liberdade em desenhar o currículo que a Escola de Aplicação da FEUSP me apresentava, deparei-me com um duplo desafio: elencar prioridades, escolher "conteúdos", desenvolver propostas de trabalho sem prescrições ou restrições de antemão.

A prática, inicialmente, configurou-se como um angustiante "salto no vazio", pois qualquer coisa é matéria para a arte - da perspectiva que adoto, entendendo que o trabalho docente em arte pode se configurar como uma espécie de trabalho artístico. 0 termo "artístico", neste caso, ainda que seja adjetivo, não diz respeito propriamente ao campo da arte, pois está operando acima e abaixo desse definição. Lembro das palavras de Zordan, que diz que algo pode "ser artístico por natureza e nunca por classificação, pertencimento, reconhecimento de campo". 0 autor indica, nesses casos, que o "ser artístico busca uma qualidade de humores apaixonados que interessam para criação, pesquisa e produção." ${ }^{15}$

O trabalho docente, sob esta perspectiva, é um trabalho de humores artísticos, pois lida, fundamentalmente, com a criação. Foi preciso algum tempo para maturar essa ideia, que, a princípio, se configurava mais com um medo relativo ao esquecimento da prática. Como se fosse possível, ao se tornar professor, esquecer o ser artista. Esta crença, porém, está infelizmente muito bem estabelecida nas mais variadas salas de aula, pois parece que uma aura de fracasso envolve aqueles que escolheram ou foram escolhidos pela educação.

Eu, por minha vez, escolhi fortemente a docência com a condição de não esquecer a criação. Procurei com rigor e atenção uma ou mais vitalidades dentro da escola que pudessem legitimar um espaço de criação que extrapolasse a sala de aula. E posso agora dizer que elas existem e resistem à burocratização e à pedagogização da infância e da adolescência.

Para fomentar a minha prática, recorri mais aos escritos de artistas do que à literatura da área, pois foi com os artistas com quem travei maior possibilidade de diálogo. Quando Marcel Duchamp, em seu célebre e curto texto $O$ ato criador $^{16}$, fala do coeficiente artístico como o resultado do conflito entre a intenção e a realização de uma obra (e como, ainda assim, isso representa apenas um dos pólos da criação, pois o outro é ocupado pelo espectador), penso na possível correspondência desse coeficiente com o trabalho pedagógico e o ato de ensinar. Do que é pensado ao que chega na sala de aula, inúmeros são os atravessamentos que ocorrem, transformando a matéria em movimento.

Não é raro os artistas se munirem de cadernos, anotações, pastas, objetos colecionados que ficam à deriva de uma oportunidade para serem empregados, ou para que alimentem, de alguma forma, a criação. Pois foi assim que encarei a docência, como a constituição de um arquivo formado da junção daquilo que me mobiliza como professor com aquilo que afeta os alunos. A coleção é de vivências, incidências, acasos, problemas de percursos, proposições. Nada disso se sobrepõe, mas se compõem, misturando-se, transformando-se a cada ano, a cada turma.

15 ZORDAN, Paola. Disparos e excessos de arquivos. Anais ANPAP 2011. Disponível em: http://www.anpap.org.br/ anais/2011/pdf/cpa/paola_zordan.pdf. Acesso em 12/06/2015. p. 4245.

16 DUCHAMP, Marcel. O Ato Criador. In: BATTCOCK, Gregory. A nova Arte. São Paulo. Perspectiva: 2004. 
Não apenas os escritos de artistas me alimentavam mas também um interesse particular numa filosofia; com ela, a ideia de uma docência artística cabia bem. A partir das lições emancipadoras que o pensador francês Jacques Rancière traz na figura do mestre ignorante ${ }^{17}$ Jacotot, cuja maior subversão está na inflexão do saber como poder e embrutecimento para uma partilha daquilo que se ignora, a partir do encontro com uma filosofia dos afetos de Spinoza e de um pensamento baseado na diferença de Deleuze, encontrei caminhos de articulação entre aquilo que intuía e o que o cotidiano concretizava em mim como professora na sala de aula.

Efeito dessas tramas e, sobretudo, do embate com o cotidiano escolar, especialmente do primeiro entrave que me assolou em chão de aula - a noção de aula de arte como algo espontâneo e desinteressado -, criei, ainda que sem tanta consciência disso, uma espécie de inventário como procedimento de trabalho com as turmas do $6^{\circ}$ ano.

Os Cadernos do olhar pretendiam criar uma sistemática de registro ativo dos conteúdos movimentados na aula, relacionando sua técnica (forma) com o que havia sido tratado (conteúdo). O registro de cada aluno deveria ser assumidamente diferente, único, desde o texto elaborado até o projeto visual da página.

Além disso, com os Cadernos do Olhar busquei abrir uma brecha para uma escrita criativa nas aulas de artes visuais e sintetizar, nesse fio condutor, todo um processo de aprendizagem vivido pelo aluno.

Estava ali naquela proposta a gênese do que me proponho aqui: uma espécie de dicionário trivial e despretensioso nascido do embate entre o campo da arte-educação e aquilo que dizem os alunos e alguns artistas, misturado e transformado à moda da filosofia da diferença. Sem perder de vista, entretanto, a visualidade do campo da escrita, intersecção entre desenho (design) e palavra.

Assim como no Caderno do olhar, serão apresentados vinte e três verbetes (com exceção das letras usadas para palavras estrangeiras: $\mathrm{K}, \mathrm{W}$ e Y), ora fabulados, ora acadêmicos. Todos os verbetes são frutos do contato entre prática docente, filosofia da diferença e arte contemporânea. O objetivo é "trazer para essa escrita sons de aulas, blocos de escolas sem lembranças, vidas presentes e ativadas, precipitadas, multiplicadas em suas conexões", dando-lhes "um máximo de extensão polívoca." ${ }^{18}$

Trata-se de um experimento atravessado por inúmeras inspirações em diálogo com aquilo que denominarei "suposta cultura escolar em torno da arte". Junto a ela, circulam o Dicionário de ideias feitas ${ }^{19} \mathrm{e}$ o inacabado Bouvard e Pécuchet ${ }^{20}$, de Flaubert, porém, longe de querer ser "uma enciclopédia da estupidez humana", nesta pesquisa eles inspiram apropriações, como as faz o autor - dos chavões e sensos-comuns -, neste caso, que rondam a arte na escola.

o Dicionário de ideias feitas opera como guia de opiniões, tão pertinentes e evidentes 
no cotidiano escolar. O mesmo efeito se apresenta em Bouvard e Pécuchet, através de uma ácida crítica à leitura enciclopédica, pois "os livros que devem aproximá-los do que eles devem ser os afastam, prescrevendo-lhes o que devem fazer - estupidez e virtude, santidade e tolice daqueles que tentam com zelo fazer isso mesmo que eles já são, transformar em atos as ideias que eles obtiveram e cuja natureza se esforçam silenciosamente para encontrar, por toda a sua existência, em uma cega obstinação." ${ }^{21}$ Algo disso, ainda que satiricamente, diz muito sobre o que circula na educação.

Já das aspirações poéticas, esta pesquisa toma de empréstimo o Alfabeto de Paul Valéry, no qual cada letra corresponde a uma hora do dia. Proponho, assim, uma experimentação da escrita, também espelhada no método Valéry-Deleuze da pesquisadora Sandra Mara Corazza, fruto de elementos conceituais do pensamento em prosa de Valéry, junto ao pensamento da diferença de Deleuze, "buscando o rigor e a consistência, sem perder a sensibilidade". ${ }^{22}$ Assim, é apresentado um aporte instigando a reflexão sobre o informe na educação, tendo em vista que estes são sempre ficções a produzir o efeito de real (verdade) no mundo.

Essa pesquisa também deve muitos aos abecedários de Gilles Deleuze, compilados nos Mil Platôs, (1980) escrito com Félix Guattari, nos quais se apresentam, por meio da arbitrariedade da ordem alfabética, um apanhado de conceitos rizomaticamente ligados uns aos outros, sem hierarquia.

Portanto, para essa pesquisa, a filosofia da diferença será o personagem conceitual agente de enunciação -, que floresce o plano de imanência (solo sobre o qual é possível criar o impensado do pensamento). Segundo Deleuze e Guattari, o personagem conceitual seria aquela figura que, por mais borrada ou inominada que seja, opera como uma sombra no trabalho, uma espécie de heterônimo do autor.

Escolhi algumas práticas artísticas contemporâneas que funcionarão também à moda deleuziana, como as figuras estéticas, cuja intenção é sempre romper com os afetos e perceptos ordinários. O critério de escolha foi bastante simples: busquei, nos discursos dos artistas selecionados, algo que enunciasse um vestígio, suas operações e procedimentos artísticos capazes de mobilizar o impensado; neste caso (das figuras estéticas) - o impercebido. Do contágio com esse material também foram propostos experimentos em sala de aula, nos quais o pensamento artístico não servia como um conteúdo a ser ensinado, mas como uma provocação à invenção, operando, consequentemente, uma fissura no conforto instaurado daquilo que é conhecido como aula.

Ou seja, trata-se de uma dupla experimentação: arte contemporânea e filosofia da diferença juntas e misturadas até o ponto de nos confundirem: "o plano de composição da arte e o plano de imanência da filosofia podem deslizar um no outro, a tal ponto que certas extensões

21 FOUCAULT. Michel. 1964 - Posfácio a Flaubert (A Tentação de Santo Antão). In:

literatura e pintura, cinema e música." Rio de Janeiro: Forense Universitária, 2009. p. 95.

22 CORAZZA, Sandra Mara. Método Valéry-Deleuze: um drama na comédia intelectual da educação. IN: ___ . 0 que se transcria em educação? Porto Alegre: UFRGS, 2013 p. 4 
de um sejam ocupadas por entidades do outro."23

Por fim, acrescentei falas provindas do coro confuso dos alunos e da escola, escancarando ideias preconcebidas: ao centro, o naipe de sopranos estridentes da arte-educação; ao fundo, a voz rouca de uma filosofia que se contrapõe à melodia de normatização da arte na escola; e, ainda, impressões que me escapam sussurradas no volume mínimo e transbordando as mais variadas formas de pensamentos traduzidas em palavras. As facetas de alguns discursos, visto à moda barthesiana dos Fragmentos de um Discurso Amoroso - como palavras destituídas de seus sujeitos - foram "levadas a própria sorte", em um dis-cursus parecido ao ato de correr para todo lado. Essas palavras devem ser ouvidas naquilo que se torna repetição constituinte da aula de arte.

A intenção com este trabalho é, sobretudo, encontrar dispositivos, as linhas emaranhadas de um novelo como

um conjunto decididamente heterogêneo que engloba discursos, instituições, organizações arquitetônicas, decisões regulamentares, leis, medidas administrativas, enunciados científicos, proposições filosóficas, morais, filantrópicas. Em suma, o dito e o não dito são os elementos do dispositivo. 0 dispositivo é a rede que se pode tecer entre estes elementos. ${ }^{24}$

Com isso, busca-se identificar, na articulação entre os diversos discursos, uma suposta verdade da arte, criada no interior dessa rede, como um dispositivo que "tem sempre uma função estratégica concreta e se inscreve sempre em uma relação de poder." ${ }^{25}$ Portanto, além de entender as forças que operam na relações entre os termos arte e educação, que parecem, por ora, consonantes, será preciso colocar em xeque a hegemonia desses discursos.

Entretanto, operar nas nuanças e minúcias apontadas pelos diversos discursos em torno da disciplina "Arte" seria por si só um trabalho de fôlego, e a intenção aqui é parte genealógica, parte experimental. Por saber disso, como questão de método, buscar-se-á entender essa suposta cultura escolar em torno da arte, a partir da análise das metanarrativas advindas da fala dos alunos, da literatura da arte-educação e dos documentos oficiais. A intenção, por fim, é encontrar as linhas de enunciação e curvas de visibilidade que preenchem a disciplina "Arte" com conceitos e finalidades. Pois, segundo Deleuze são as linhas de enunciação, curvas de visibilidade e linhas de força que constituem o dispositivo, e não o contrário.

Dessa grande mistura, constitui-se um abecedário que evidencia em forma de verbetes o que localizo como as principais linhas que compõe essa pesquisa: uma primeira, que se reporta a alguns saberes específicos da arte-educação, e, especialmente, ao modo como eles resvalam e reverberam na minha prática; uma segunda linha, que se refere ao desejo de atualizar tanto a escola quanto o lugar da arte nesta instituição como potencializadores da vida - dessa grande

23 DELEUZE, Gilles; GUATTARI, Félix. O que é a filosofia? trad. Bento Prado Jr. e Alberto Alonso Muñoz. São Paulo: Editora 34, 1992. p. 89

24 FOUCAULT, M. Microfísica do Poder. org., intr., revisão técnica de Roberto Machado, Rio de Janeiro: Graal, 1993. p.. 244. 25 AGAMBEN, Giorgio., op. cit. p. 2. 
linha, nascem verbetes que apresentam algumas proposições de sala de aula. E, finalmente, uma terceira linha, que talvez funcione como uma costura de todas, pois é fruto do encontro da filosofia da diferença como suporte para tais atualizações com o encantamento que algumas práticas artísticas contemporâneas exercem em mim, como se cada experiência fosse capaz de me reconduzir à sala de aula, à escola e à educação com mais vitalidade e vontade de fazer diferença brotar naquelas terras, por vezes abandonadas. 



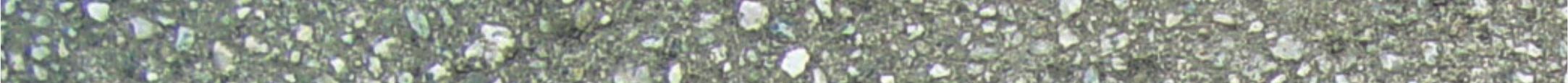

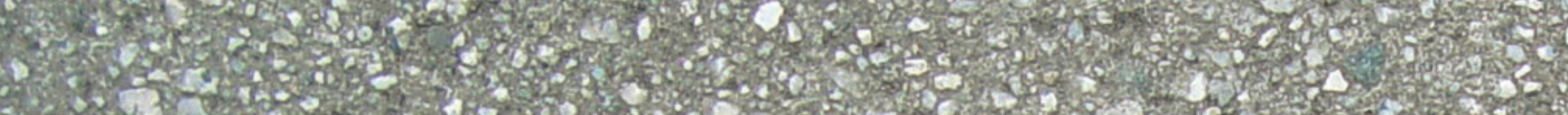

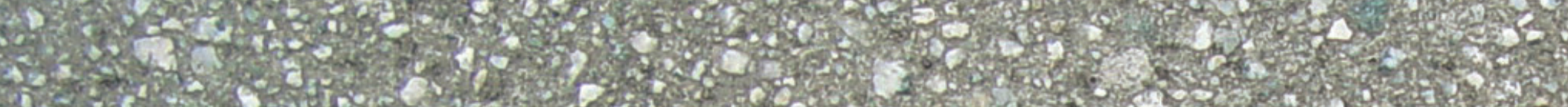

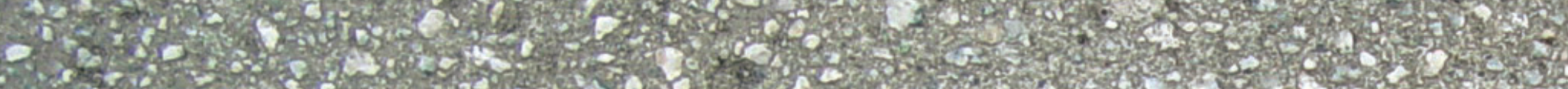

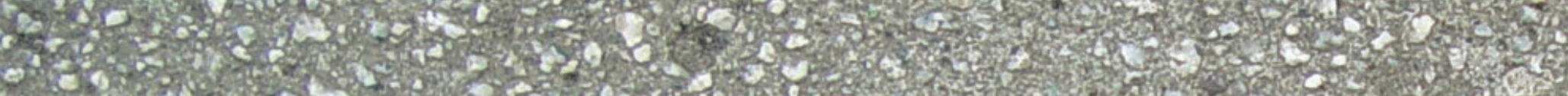

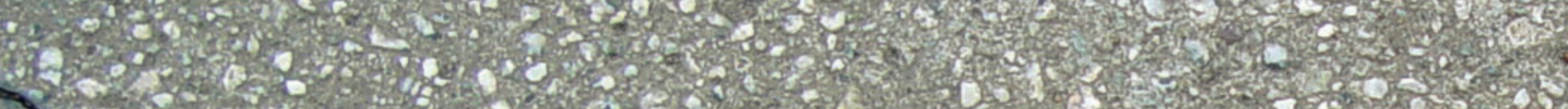

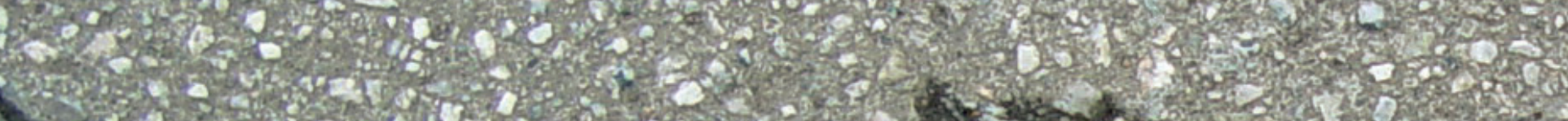

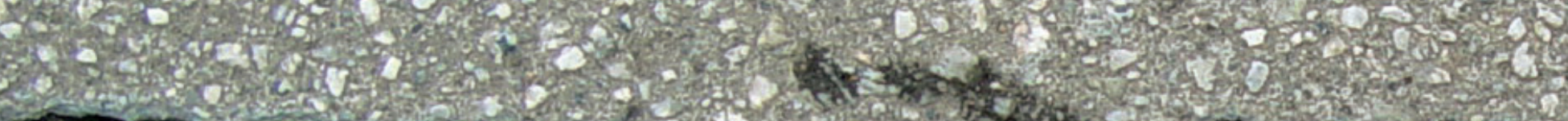

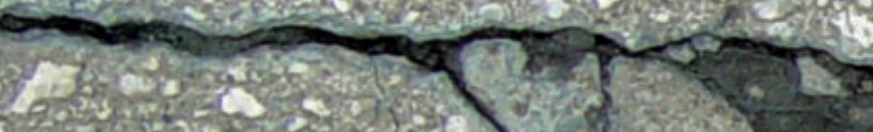

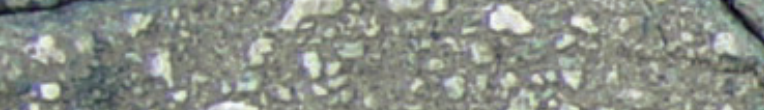

1.

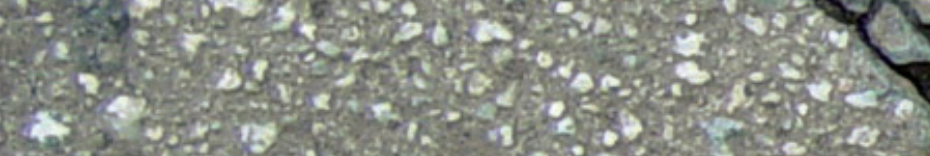

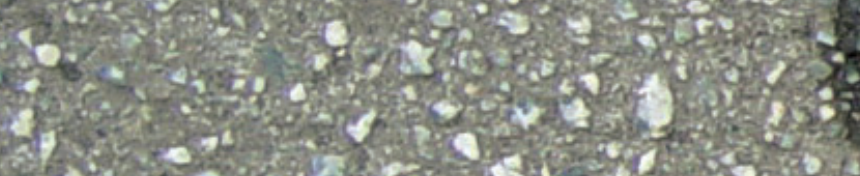

s:

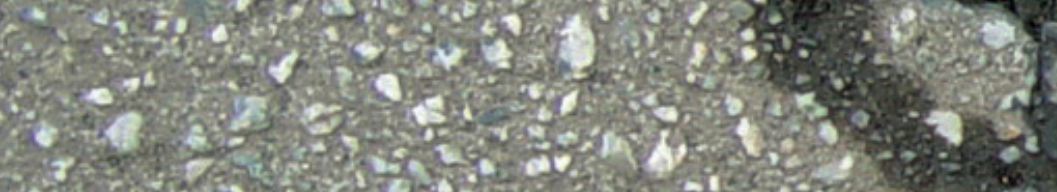
1.

F.

19.

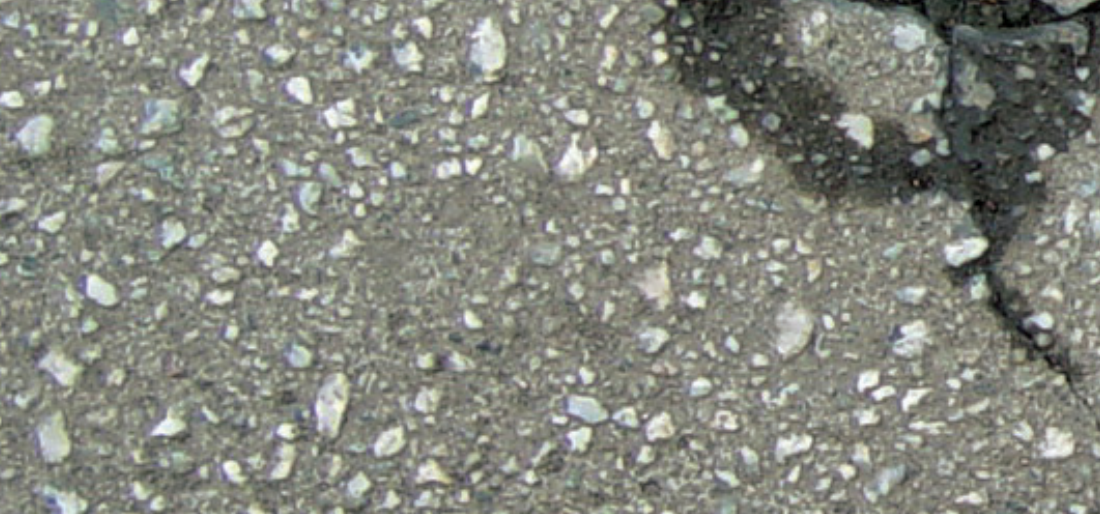

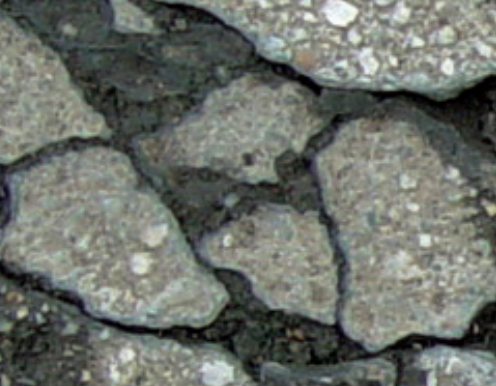

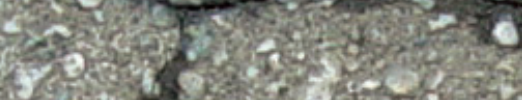

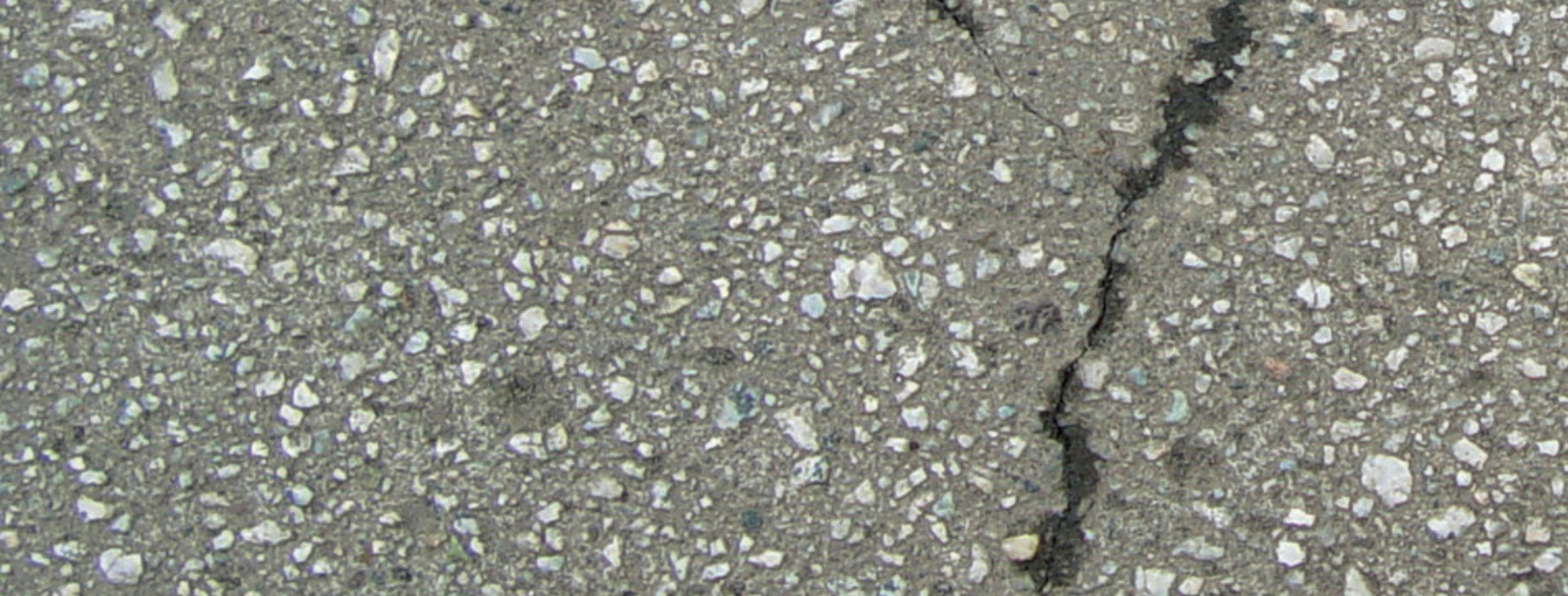

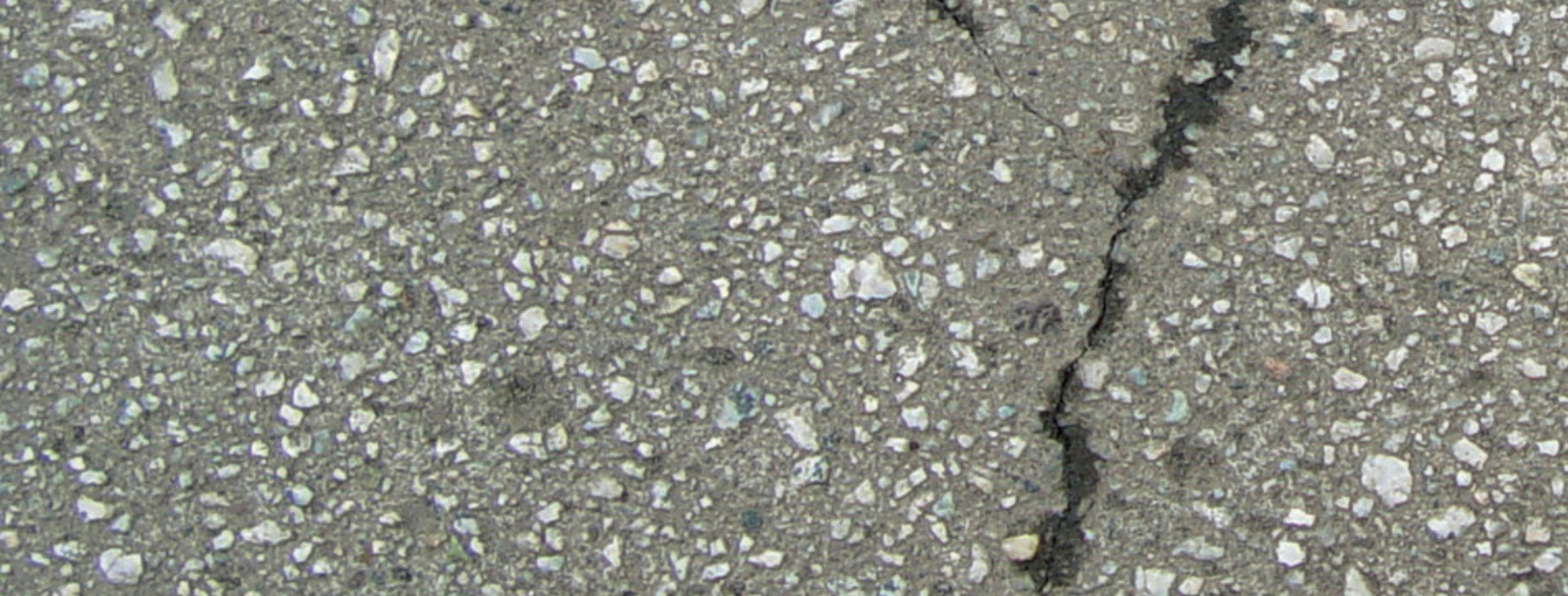

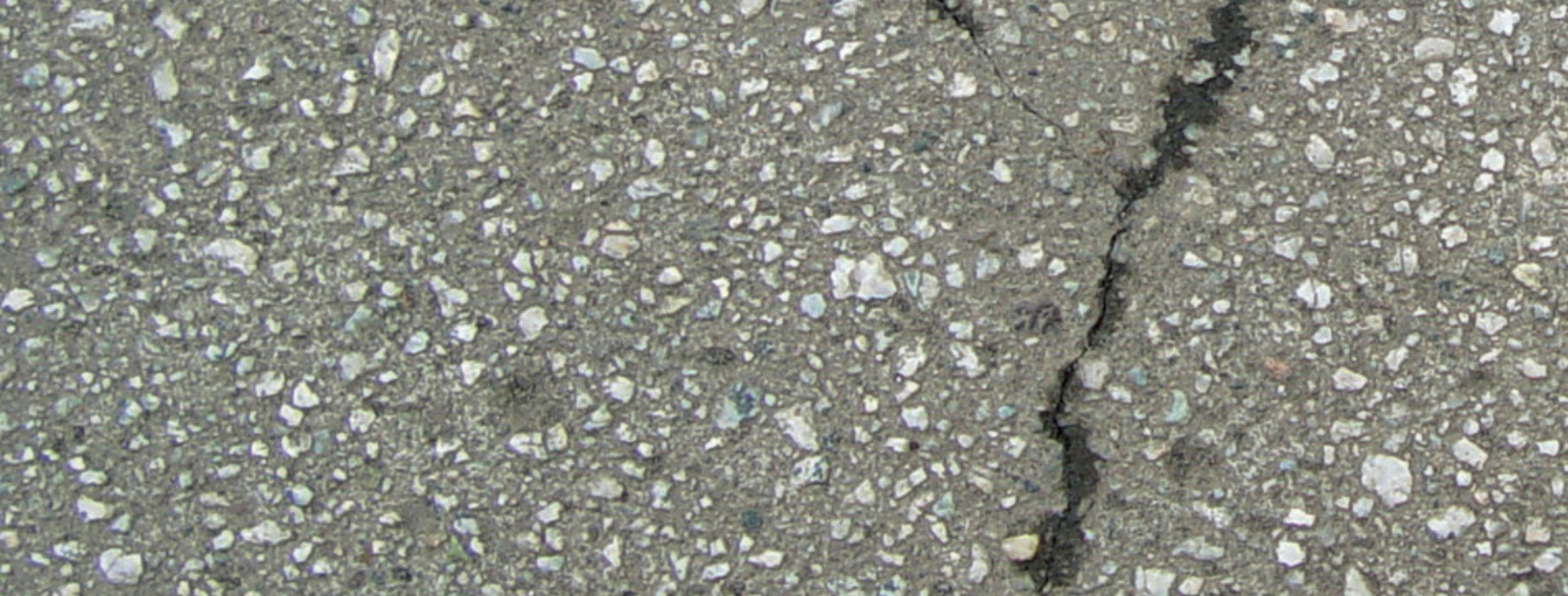

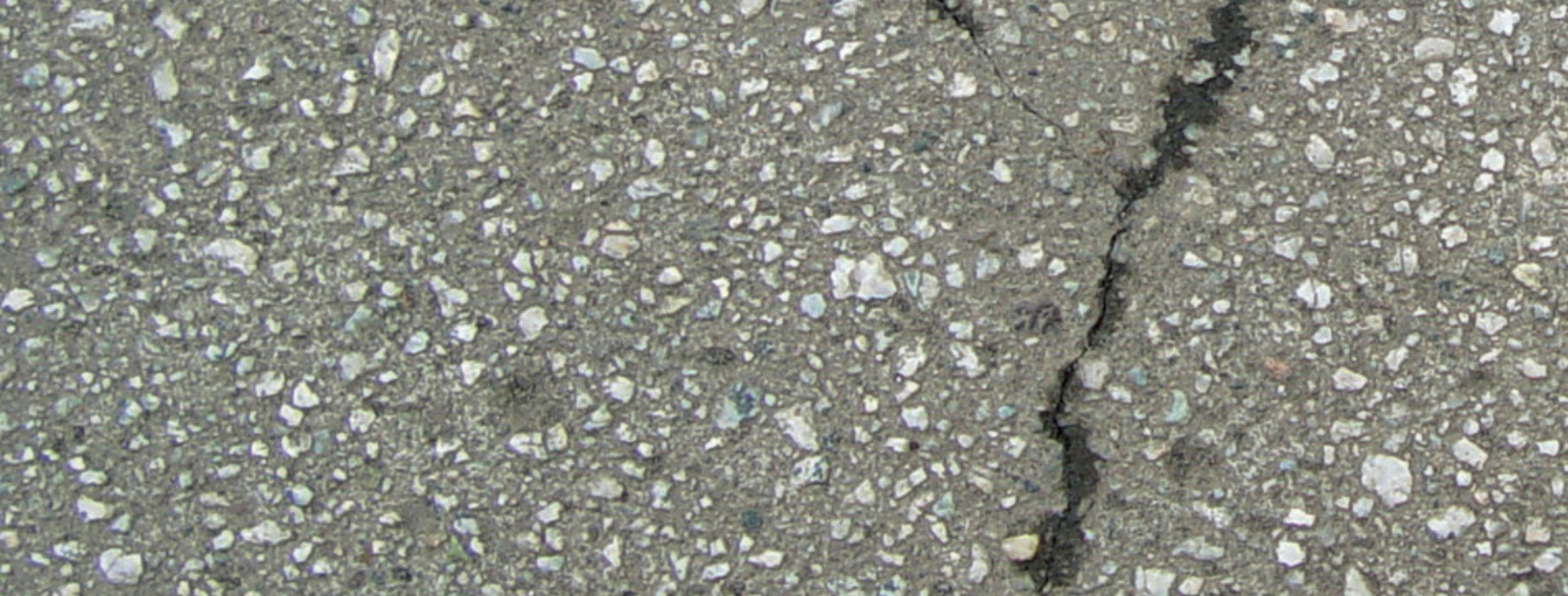

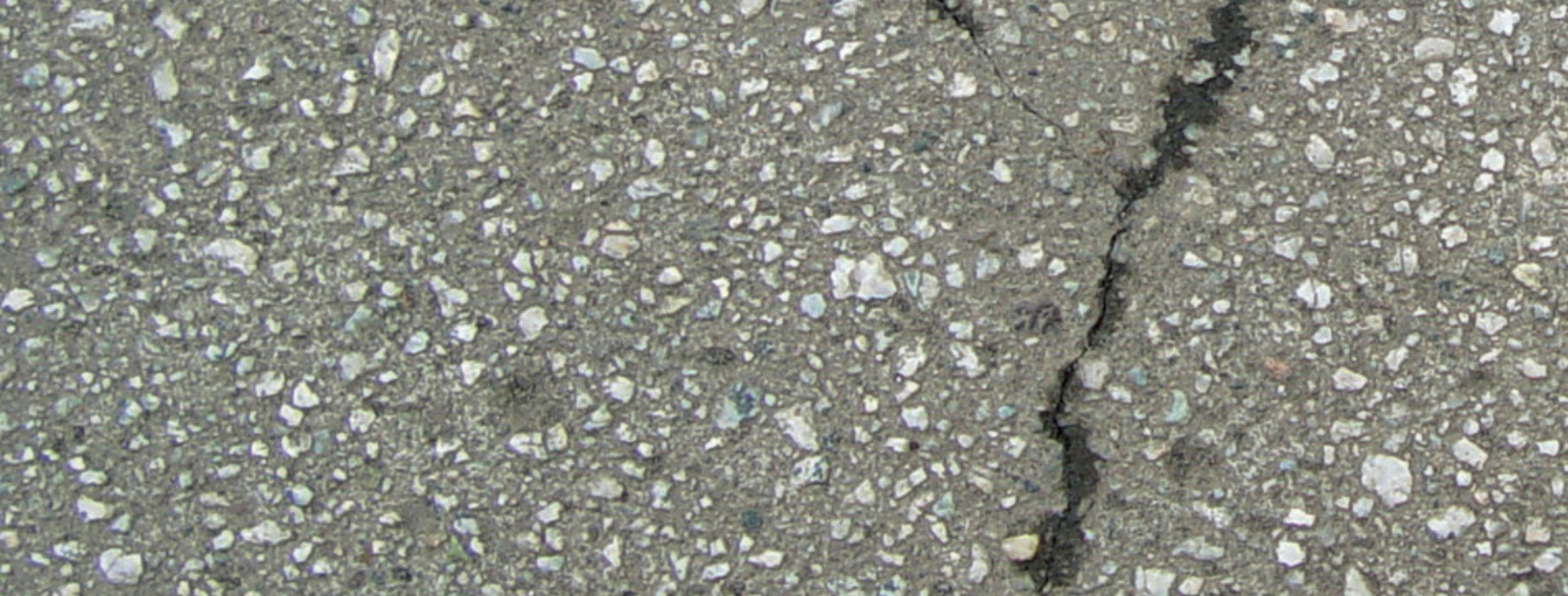

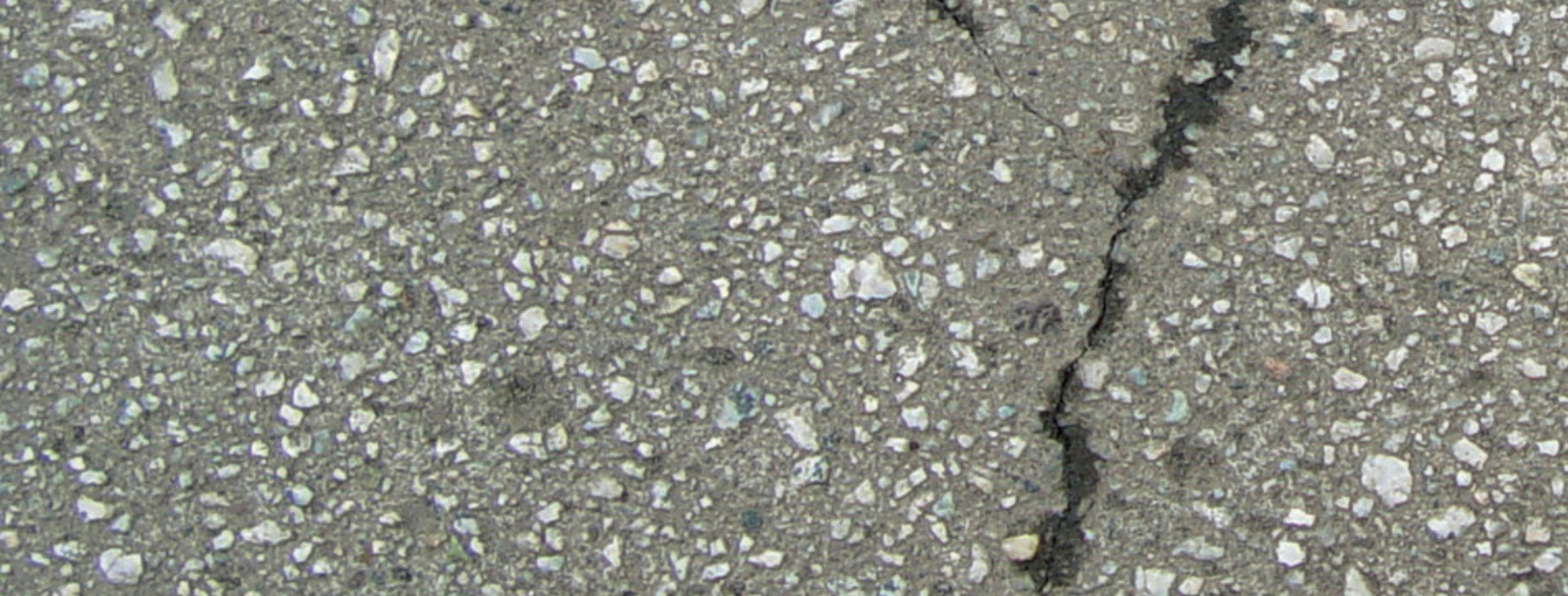

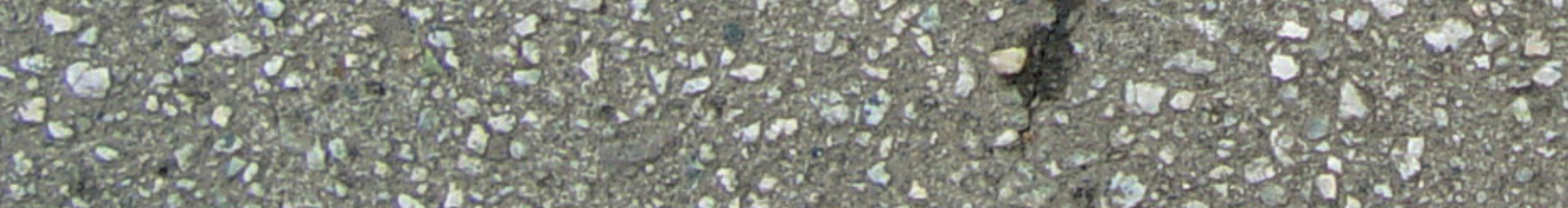

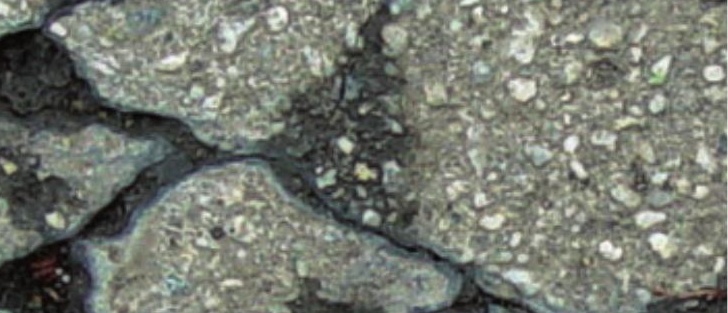

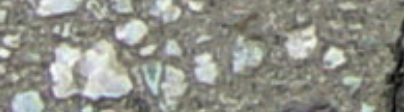

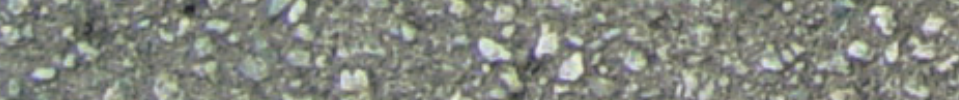

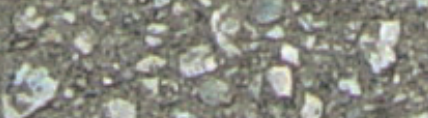

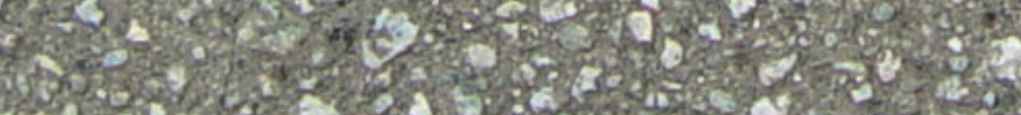

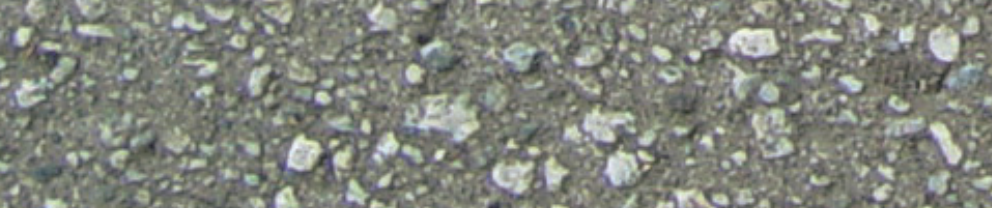

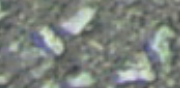

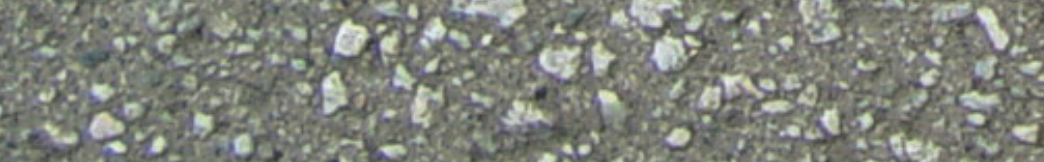




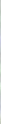

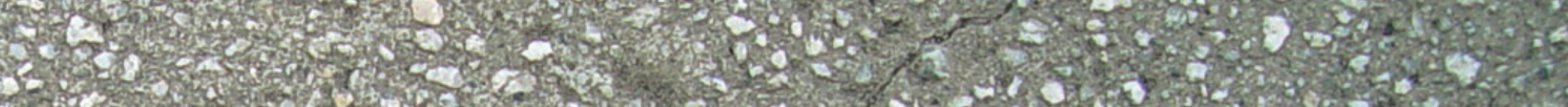

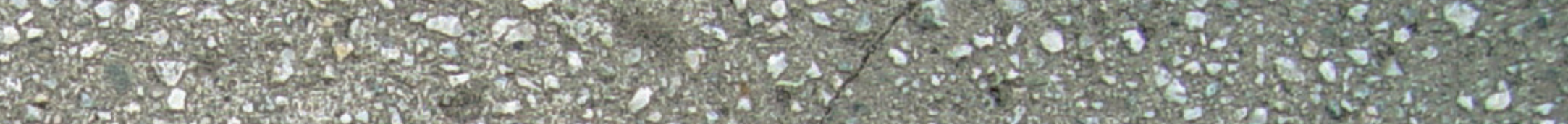

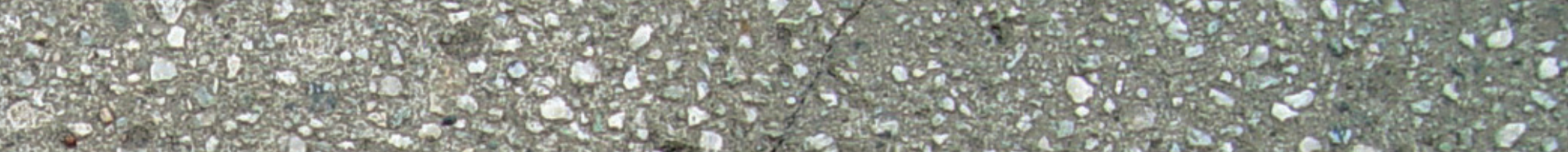

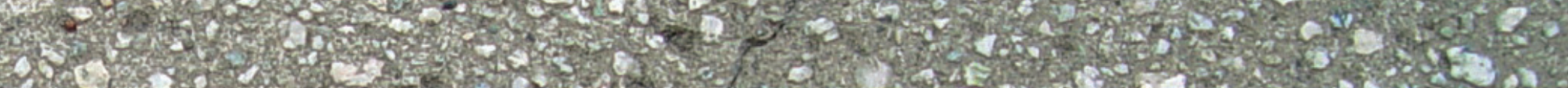

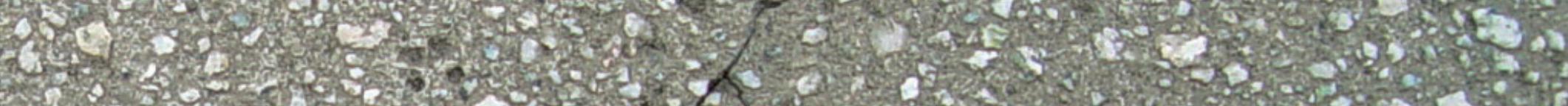

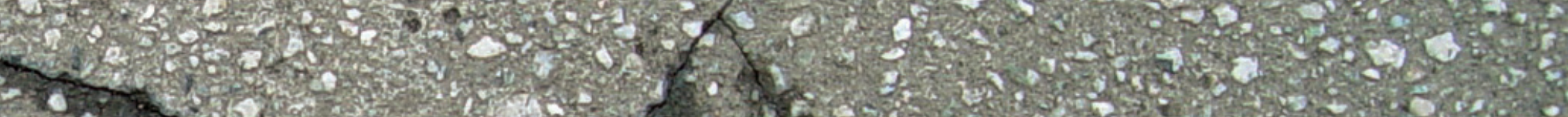

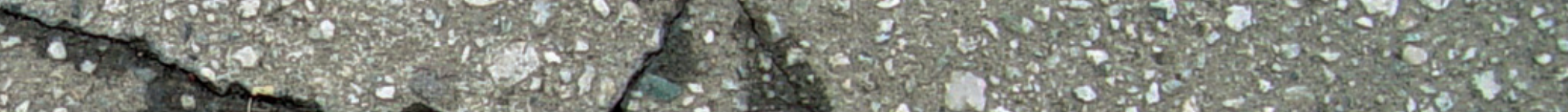

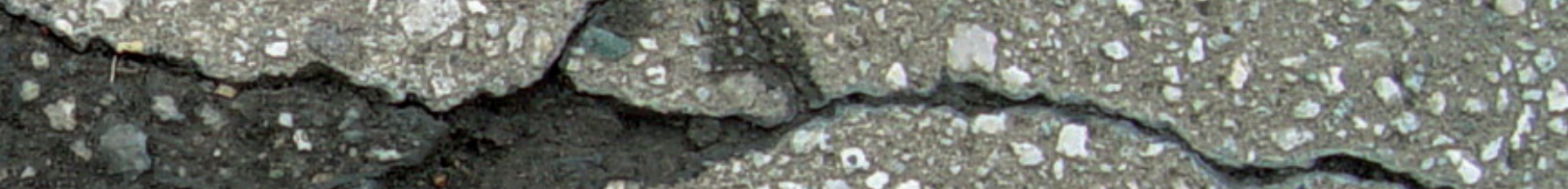

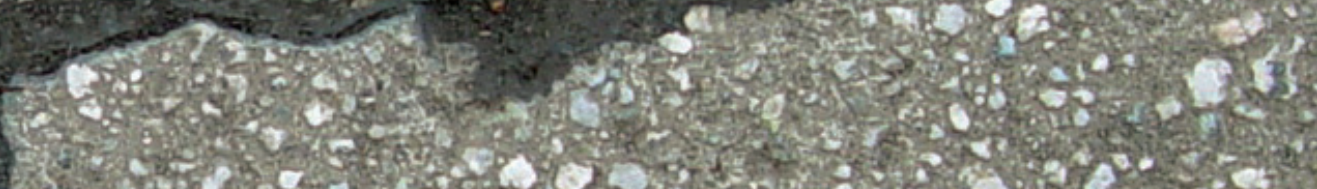

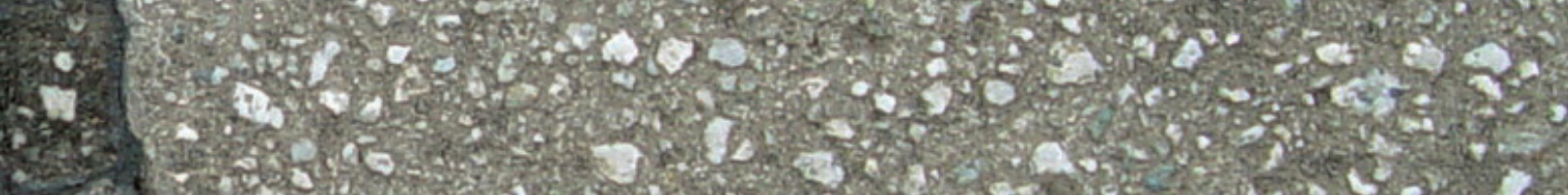

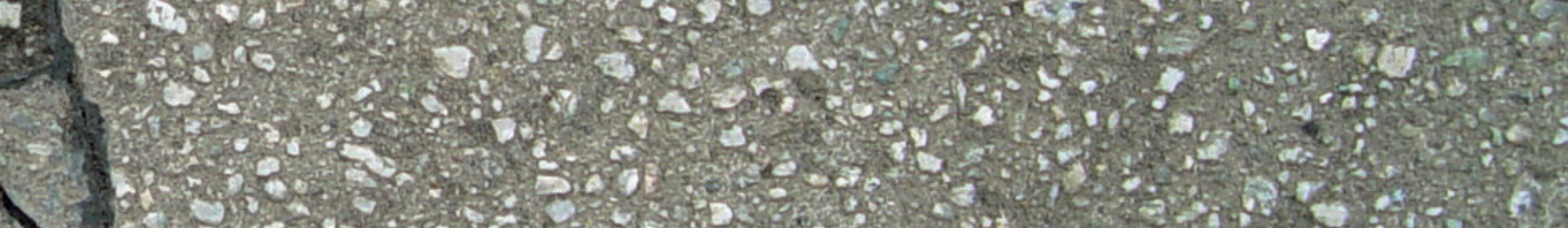

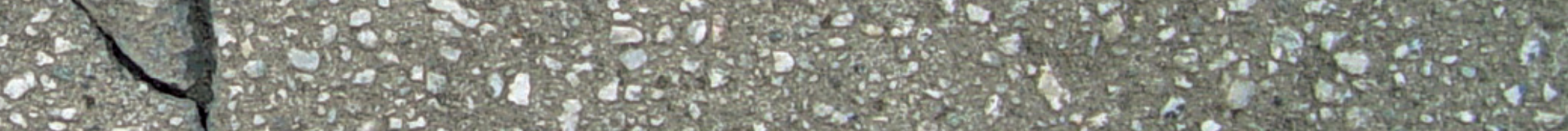

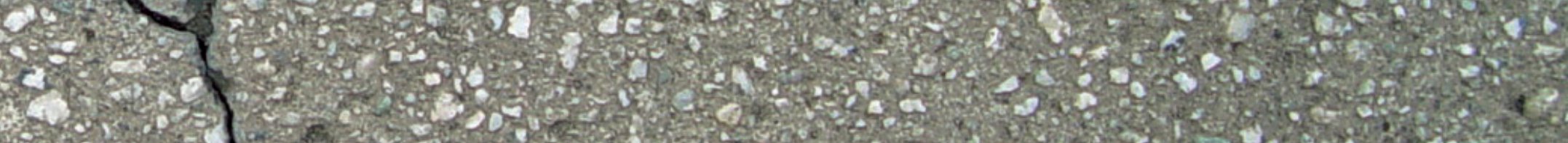

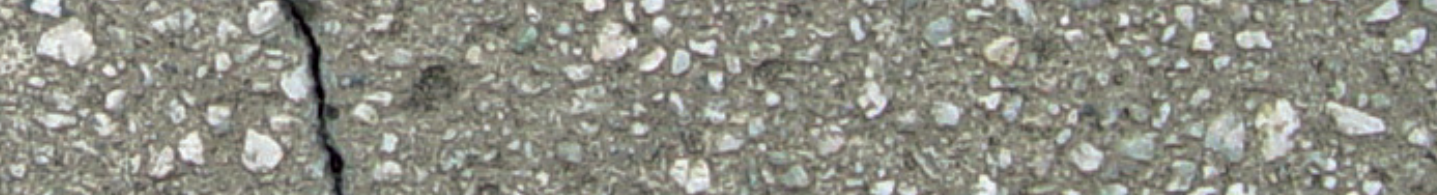

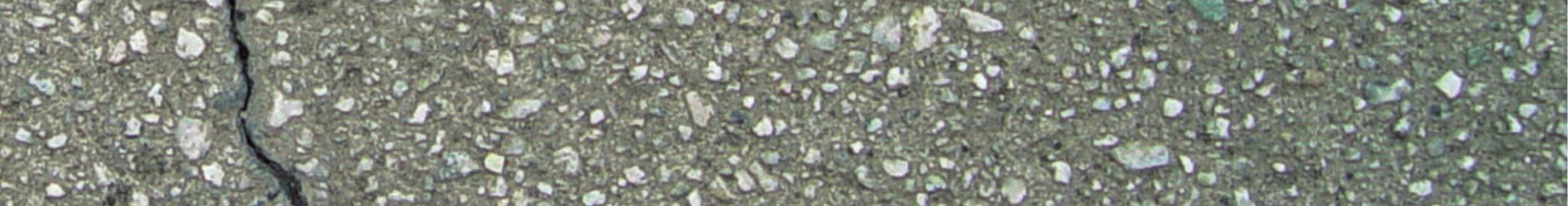

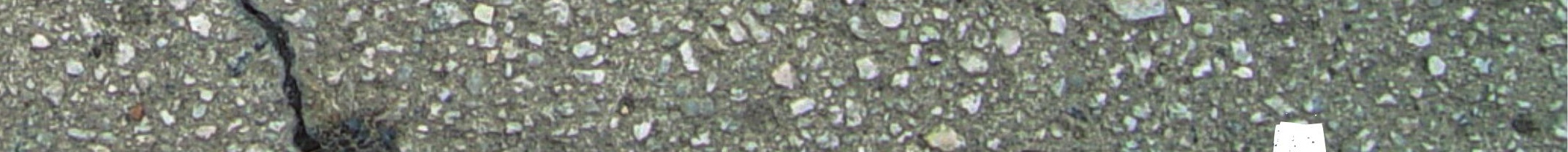

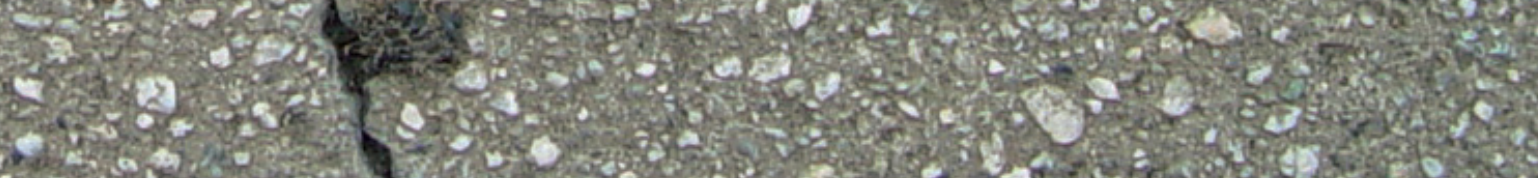

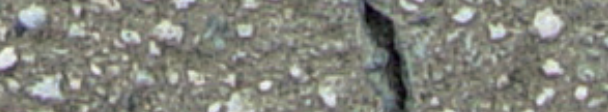

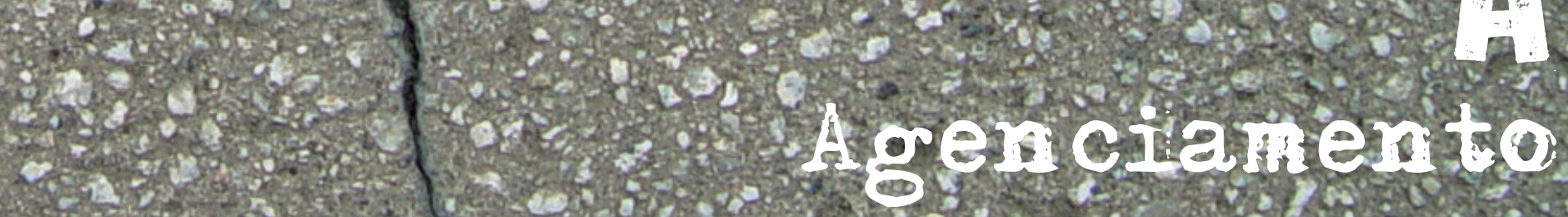

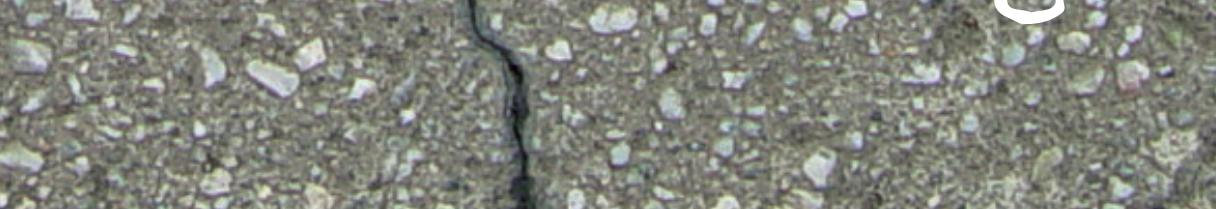



"Educação é "patchwork", colcha de retalhos sem avesso nem direito.

É criação, composição, invenção". ${ }^{1}$

O conceito de agenciamento de Deleuze e Guattari opera um duplo ataque ao bom senso: aos fundamentos que tornam possível pensar em sujeitos dotados de uma natureza humana dada, a priori, e também à ideia de um conhecimento puro e universal.

A destituição de uma suposta interioridade unitária e constituinte dos desejos proposta pelos pensadores acima é, portanto, premissa de um trabalho que pretende se desenvolver com base na criação de novas possibilidades de modos de vida. Ou seja, a partir de trabalhos potencializadores de experiências e das capacidades criadoras de todo homem, sobretudo no campo da educação.

Esse conceito pode ser compreendido por uma dupla chave: agenciamento maquínico e agenciamento coletivo de enunciação. Para Deleuze e Guattari, o agenciamento opera por dois eixos, ou traços, sendo que cada um deles se compõe de dois segmentos, um de conteúdo e outro de expressão. O primeiro, horizontal, é o "agenciamento maquínico de corpos, de ações e de paixões, mistura de corpos reagindo uns sobre os outros"; o outro, o agenciamento coletivo de enunciação refere-se a atos e enunciados, "transformações incorpóreas atribuindo-se aos corpos". Analisando esses eixos, os autores dizem que "segundo um eixo vertical orientado, o agenciamento tem ao mesmo tempo lados territoriais ou reterritorializados, que o estabilizam, e pontas de desterritorialização que o impelem."

Assim, o agenciamento está diretamente relacionado ao modo de produção do real, incidindo, por um lado, sobre os corpos e as paixões e, por outro, sobre as transformações maiores - de enunciações, remetendo a um regime coletivo e territorializante. Os agenciamentos se ligam duplamente às instituições territorializadas, como o casamento, o judiciário, a escola, e também aos campos de desejos desterritorializadores - como os devires. Eles agem em um vínculo duplo, com um enunciado feito por dois pólos de um mesmo conceito: na manutenção dessas instituições e em sua desconstrução por meio de incorpóreos que nelas intervêm.

O agenciamento é sempre composto por expressão e conteúdo. Trata-se, sobretudo, de misturas, transformações incorpóreas. O conteúdo seria como uma lição das coisas, a trama dos corpos. Já as expressões são os expressos, os incorpóreos, lições dos signos, palavras. Para Deleuze e Guattari, foram os estóicos que primeiro teorizaram a respeito dessa independência entre conteúdo e expressão, pois eles distinguiam as ações e as paixões dos corpos.

Por meio do conceito de agenciamento, Deleuze e Guattari elaboram uma crítica à

1 DELEUZE, G. GUATTARI, F. Mil platôs: capitalismo e esquizofrenia. Vol. 4. tradução de Suely Rolnik. São Paulo: Ed. 34, 2002. p. 182

2 DELEUZE.G; GUATTARI, F. Mil platôs: capitalismo e esquizofrenia., vol. 2. tradução de Ana Lúcia de Oliveira e Lúcia Cláudia Leão. São Paulo: Ed. 34, 1995. p. 18. 
linguística como um modelo linear e arborescente, elaborado a partir de fatores linguísticos herméticos, e desconsiderando qualquer fator não-linguístico como variável. Por exemplo, um punhal que corta a carne, são expressos (expressões) que passam pela linguagem, que são atributos da mesma, mas que no entanto, modificam o corpo. Assim, "não se pode nem mesmo dizer que o corpo, ou estado de coisas, seja o 'referente' dos signos." ${ }^{3}$

Os expressos vão intervir no conteúdo e isso será feito com um movimento de desterritorialização que arrebata, simultaneamente, tanto as formas de expressão quanto as de conteúdo. Há, portanto, dois tipos de agenciamentos, um maquínico, que age sobre os corpos, e o agenciamento coletivo de enunciação, que se dá no nível da língua.

Outro exemplo trazido por Deleuze e Guattari é o agenciamento feudal, composto por agenciamentos maquínicos (conteúdo/corpo) e formados pelos corpos do suserano, do vassalo, pelas armas e pelo agenciamento coletivo de enunciação (expressos e transformações incorpóreas), como o cavaleirismo, a relação de submissão, os brasões, a obediência, a ideia de amor, etc.

O principal erro que se atribui ao conceito de agenciamento é a suposição de que o conteúdo determina a expressão. Muito pelo contrário, o agenciamento é formado pela mistura dos corpos, "compreendendo todas as atrações e repulsões, as simpatias e antipatias, as alterações, as alianças, as penetrações e expansões que afetam os corpos de todos os tipos, uns em relação aos outros." ${ }^{4}$

Dessa forma, cada indivíduo é atravessado por esses grandes agenciamentos maquínicos e coletivos de caráter reprodutor, constituídos por máquinas abstratas, cuja função tende a reduzir o campo de experimentação. Com a função de comandar esses grandes agenciamentos, em forma de máquina abstrata de poder, encontra-se a escola.

O pensador brasileiro Luiz Fuganti faz uma importante leitura do conceito de agenciamento proposto por Deleuze e Guattari para pensar a educação. Segundo Fuganti, os grandes agenciamentos maquínicos operam diretamente no aparato educativo, constituindo a "ideia de uma forma humana espiritual superior à natureza emerge como ilusão de consciência, a qual pressupõe um plano de realidade separado como origem da representação do real e que legitimaria o corte homem/natureza, cultura/natureza (...)". ${ }^{5}$

Para Fuganti, a natureza, ao contrário desse tipo de pensamento binário, não é um dado, mas uma fábrica, tudo nela é incessantemente fabricado, tudo está em movimento, o que ela produz é o real. Portanto, tudo se encontra dentro da natureza, não há uma natureza humana anterior, pronta: ela também está diuturnamente produzindo-se a si mesma.

Assim funcionam os agenciamentos, ultrapassando o modo de pensar da tradição, destituindo, por um lado, a noção de natureza humana como um dado, e, por outro, desconstituindo as verdades universais e puras, como a linguagem, a subjetividades e o conhecimento.

Assim, a educação - lugar por excelência de transmissão e perpetuação desses valores ligados a "uma prática moral cada vez mais desinteressada", e transmissora de "um conhecimento

Idem, ibidem, p. 21

Idem, idibem.

FUGANTI, Luis. Agenciamento. In: AQUINO, J. G. CORAZZA, S. M. (orgs.). Abecedário: Educação da diferença.

Campinas: Papirus, 2009. p. 20 
racional e científico cada vez mais universal, apesar de cada vez mais especializado"6 - torna-se um espaço privilegiado, onde, por meio de agenciamentos de poder, os agenciamentos maquínicos não param de reproduzir corpos eficientes. É aí também que os agenciamentos coletivos de enunciação não cessam de se misturar aos corpos, produzindo modos de subjetividades considerados normais, através da soltura e captura dos desejos.

Não obstante, um agenciamento é sempre constituído por um campo do desejo recaindo sobre aquilo que o constitui; o indivíduo, por sua vez, não é uma forma pronta crescendo no mundo (cenário, conjunto de dados) aos quais ele se contentaria em reagir. $O$ indivíduo só se constitui ao se agenciar.

Dessa forma, precisamos nos questionar sobre os tipos de agenciamentos de poder que operamos na educação. Se, desde a modernidade, a produção do real parece estar presa à ideia de consciência unitária e identitária, a um conhecimento racional oriundo de uma verdade científica, o que fazemos, em educação, além de reproduzir e transmitir esses agenciamentos que nos separam da nossa própria potência de produzir real? Ou seja, o que fazemos, em educação, para nos criar a nós mesmos e aos nossos modos de vida?

A educação seria, portanto, o espaço de destaque para que os agenciamentos operem pequenas desterritorializações que prontamente se reterritorializam em outras coisas, modulando, assim, a decodificação do desejo. O agenciamento é pensado como aquilo que mistura, repele, liga, conecta, intervém, e, principalmente, é a máquina que nos faz devir o que somos e o no que nos transformamos a cada momento.

Isso posto, não seria então desejável que a educação, ao invés de operar pela cristalização de modos de vida (abafando a potência da invenção de impensados e informes) trabalhasse a favor da potência e da afirmação? Guattari, a este respeito, diz que, em educação, "a única finalidade aceitável das atividades humanas é a produção de uma subjetividade que enriqueça de modo contínuo sua relação com o mundo".7

Seguindo este trilho, encontra-se esta pesquisa - um agenciamento -operando com a mistura de traços e de desejos que se aproximam e se repelem. Em seu eixo horizontal movimenta enunciados que modificam, através de afetos, o corpus da "arte" e da "educação' durante esta pesquisa, já no eixo vertical, opera com os territórios "arte" e "educação" numa tentativa fugidia de desterritorizá-los, haja visto que não há desterritorialização que não implique numa reterritorialização.

É, portanto, como um agenciamento, que essa dissertação (tese, artigo, livro, etc.), seu conteúdo e sua expressão pretendem desterritorializar e reterretorializar incessantemente, pois

um livro não tem objeto nem sujeito; é feito de matérias diferentemente formadas, de datas e velocidades muito diferentes. Desde que se atribui um livro a um sujeito negligencia-se este trabalho das matérias e a exterioridade

$\begin{array}{ll}6 & \text { Idem, idibem. } \\ 7 & \text { GUATTARI, Félix. As Três Ecologias. Trad. Maria Cristina F. Bittencourt. Campinas: Papirus, 1992. Félix Guattari, (1992, p.33) }\end{array}$ 
de suas correlações. (...). Num livro, como em qualquer outra coisa, há linhas de articulação ou segmentaridade, estratos, territorialidades, mas também linhas de fuga, movimentos de desterritorializações e desestratificação. As velocidades comparadas de escoamento, conforme estas linhas, acarretam fenômenos de retardamento relativo, de viscosidade ou, ao contrário, de precipitação e de ruptura. Tudo isto, as linhas e as velocidades mensuráveis, constitui um agenciamento. ${ }^{8}$

Desta maneira, a opção pela constituição de verbetes enuncia um agenciamento entre arte, educação, filosofia, sala de aula e tantas outras linhas, e portanto, como opera em movimento, refuta a ideia de algo acabado. Trata-se sempre de um work in progress sem o desejo de fixar verdades no que se segue; o que está em jogo são parte de movimentos, afetos, composições e arranjos, feitas nas velocidades possíveis recortadas por um espaço-tempo intenso de uma pesquisa.

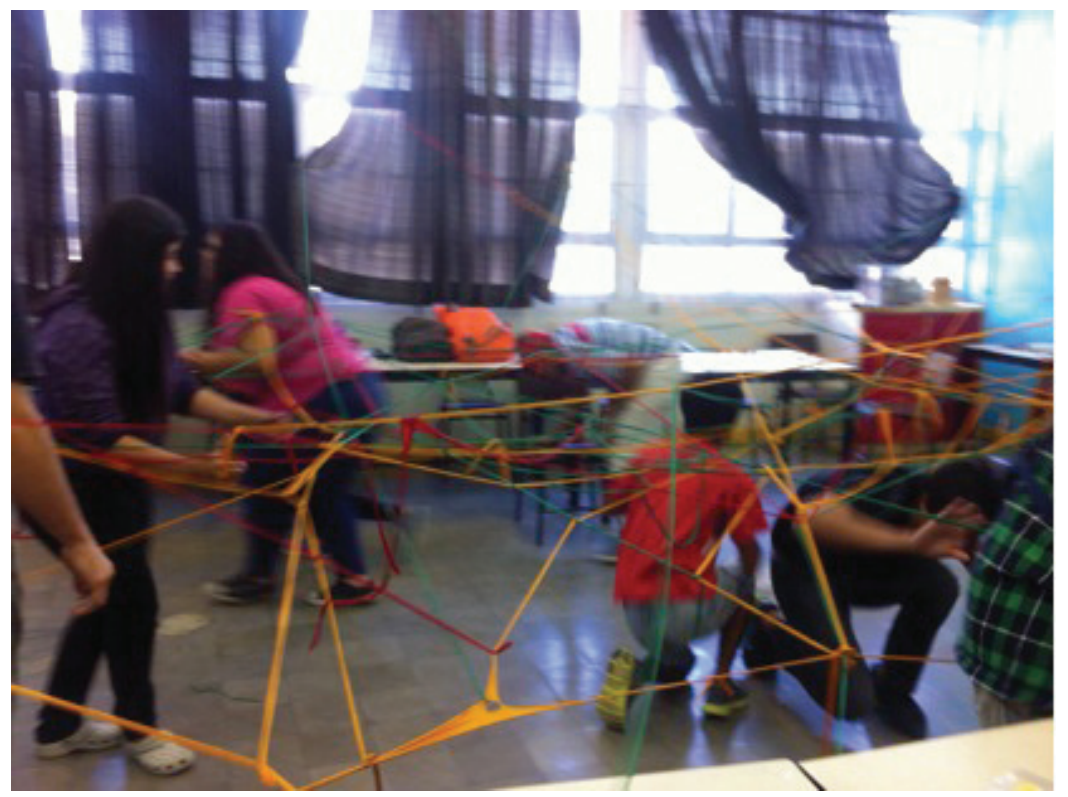

Emaranhado, desenho no espaço. Solução para linhas sem papel. Fonte: própria, 2014. 




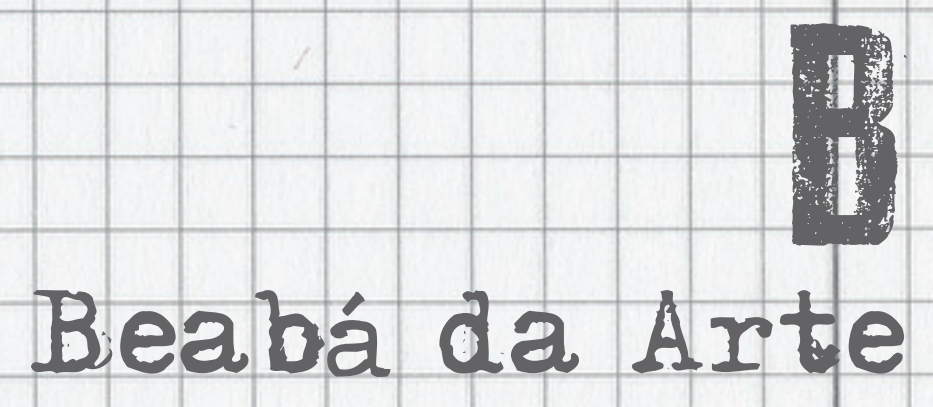



A arte-educação pelo viés trazido pela Proposta Triangular parece ter pautado suas discussões sobre arte com alguma insistência sob o signo do conteúdo. Isso parece surgir como uma resposta à reforma na educação feita no final da década de 1970. "A razão explícita dada pelos educadores é que a educação no Brasil tem de ser direcionada no sentido da recuperação de conteúdos e que arte não tem conteúdo. É algo similar ao movimento de volta ao básico nos EUA. Um simpósio foi planejado (agosto, 1989) para demonstrar os conteúdos da arte na educação. Apesar de termos a maioria dos arte-educadores das escolas secundárias defendendo o laissez-faire e alguns outros que ainda não aceitam auto-expressão, o caminho para sobreviver é tornar claro os possíveis conteúdos da arte na escola".1

Sob a perspectiva apresentada, que conteúdo ensina a arte?

Ora, a arte-/educação se estrutura como uma metodologia que entende a arte como conteúdo, esse conteúdo -oposto à "palavra" - é entendido como imagem e disso voltamos à releitura e à leitura de imagem. Nota-se, portanto, que o esforço consiste em uma espécie de instrumentalização do olhar, ignorando "a capacidade da arte em transcender modelos de apreensão [teorias e técnicas]. (...) O que se ensina são, em geral, modelos de apreensão, ou seja, precisamente aquilo que reduz a arte à condição de objeto, de conhecimento, como qualquer outro [conteúdos de representação históricos, sociais, psicológicos etc.]".

Decerto, tal empreitada é herdeira de uma estruturação típica do paradigma moderno chamada pelo pensador francês Thierry de Duve de tríade "criatividade-meio-invenção". Entretanto, não vejo maneiras em que tal tríade possa ser replicada ao contexto contemporâneo, cujas tensões extrapolaram as questões dos meios, mas o que vemos confirma o contrário disso: o paradigma moderno parece articular uma espécie de hegemonia de um tipo de arte que circula nas salas de aula, a ver pelas referências à Tarsila do Amaral, Portinari, Picasso e Da Vinci bastante reconhecidas pelos meus alunos.

Em linhas gerais, a conjunção entre um conhecimento específico da arte e sua distribuição na sala de aula a partir da revisão dos elementos que compõe suas linguagens supõe que conhecer arte "implica num envolvimento cognitivo, perceptível e sensível com as formas dessas imagens." ${ }^{\prime} \mathrm{O}$ que significaria que o ensino da arte, além de produzir imagens e contextualizá-las, deve também analisá-las em função dos meios pelos quais são feitas. Destrinchando a arte em uma linguagem decodificável, à maneira de Kandinsky, dá-se um papel para o aluno e do ponto se faz a linha e depois o plano, etc. Ou, então, a instrumentalização buscada pela leitura de imagens terá como apoio formal, não as categorias trazidas pelos meios, seja pintura, seja escultura ou BARBOSA, Ana M. Arte-Educação no Brasil: realidade hoje e expectativas futuras. Estud. av. [online]. 1989, vol.3,
n.7, p. 170-182. Disponível em: $\leftarrow$ www.scielo.br/scielo.php?script=sci_arttext\&pid=S0103-40141989000300010\&lng=en\&n $r m=$ iso $\rightarrow$, p. 181. Acesso em 29/06/2014.

2 BARBOSA, João T. apud HONORATO, Cayo. A formação do artista: conjunções e disjunções entre arte e educação, 2011. Tese de Doutorado - Faculdade de Educação, Universidade de São Paulo, São Paulo, p. 95.

3 DUVE, Thierry de. Fazendo escola lou refazendo-a?). Chapecó: Argos, 2012, p. 60.

4 FERRAZ, Maria Heloisa C.deT.; FUSARI, Maria Felisminda deR.e.Arte na educação escolar.São Paulo: Cortez, 1992, p. 81 
seja o que for, mas uma suposta "linguagem visual", que nada mais é do que a estruturação lexical do desenho que, ao acrescentar o estudo das cores, amplia-se para o entendimento da pintura.

Se reduzida a isso a aula de arte corre um risco bastante danoso, pois se "elabora uma análise plástica das obras - desconstrução dos componentes composicionais ou cromáticos, etc. - e considera a obra como um edifício formal que será o resultado de um saber-fazer, e raramente de um saber-pensar, e que aparece como uma espécie de molde operatório". Priorizando o saber-fazer do artista, reafirma-se o caráter virtuoso e genial da arte; priorizando o ensino dos meios e reforçando a linguagem artística "passamos inevitavelmente a fetichizar os meios em sua autonomia". ${ }^{5} \mathrm{E}$, ainda, mais gravemente, com isso ensina-se que a arte só se faz pelos meios, como se fosse impossível a existência de uma arte fora deles - fato que desconsidera em absoluto a produção artística contemporânea.

Entretanto, não se pretende com isso afirmar que a arte possa prescindir de seus meios e linguagens; de forma alguma, porém, um ensino de arte cujo foco esteja centrado nos códigos das linguagens artísticas pode facilmente tornar-se uma experiência vazia.

O contrário da especialização dos meios artísticos pode igualmente ser observado em discursos da arte-educação que apontam para a interdisciplinaridade como uma espécie de saída atualizada face às múltiplas e rápidas conexões contemporâneas. Dessa forma, uma sorte de relações são feitas em nome da arte na educação, que parece caber em qualquer projeto, habilitada a responder enquanto linguagem às demandas de outras áreas do saber. Disso decorre o papel que muitas vezes a arte desempenha na escola, como organizadora de eventos, decoração de festas, eixo agregador de temas transversais e daí por diante. A consequência disso, ainda que se pretenda manter uma roupagem mais atual, é que, como interdisciplinaridade, a arte na educação volta-se irrevogavelmente aos meios, a um savoir-faire de sua especificidade tida como linguagem, que nada mais é do que o procedimental técnico, e, com isso, o ensino vira um saber-fazer com propósitos externos sem o reconhecimento de que operações artísticas são operações do pensamento.

Contudo, não se pretende ignorar a importância histórica do produção teórica em torno da visualidade já produzida, a tomar como principal exemplo a Bauhaus de Itten e Klee. Haja visto que, justamente por seu modelo baseado nas corporações de ofícios - em que cada sala tinha um artista "mestre da forma" e um artesão "mestre dos materiais" -, a própria concepção e ensino bauhausiana contribuiu para a desmitificação da teoria do gênio na arte.

Ainda que no interior da escola alemã, como é de conhecimento geral, houvesse duas vertentes antagônicas em disputa: uma, centrada na objetividade e na função social de Max Bill e Walter Gropius, e outra, voltada para a interiorização e espiritualização em torno da arte, de Klee e Kandinsky, a ideia que norteava a função do artista estava, em primeiro lugar, em seu caráter social e sua relação direta com a educação e, em segundo, comprometida com a criação contínua como produção do real, através de uma linguagem visual.

Nesse sentido, Albers, exímio artista e educador da Bauhaus, Black Mountain College e 
Yale, apresenta para nós, professores de arte, uma excelente pista operacional que vai, inclusive, na contramão de um ensino pautado da especificidade dos meios artísticos.

Em uma palestra para seus alunos na Black Mountain College, Joseph Albers propõe algo que, naquela época, era distante do que se pensava em arte e educação, pois, para Albers, "arte diz respeito ao como e não ao o quê; não ao conteúdo literal, mas à representação do conteúdo factual". 6 Ou seja, o artista propunha em seu curso sobre o estudo da cor, além de pensá-la como algo absoluto - uma teoria a ser replicada -, que seu estudo fosse feito por suas interações e, sobretudo, pela experimentação.

O principal objetivo de Albers em educação era ajudar seus alunos a enxergarem melhor e com acuidade; por isso a importância em conhecer a fundo os elementos da linguagem visual. No entanto, a linguagem visual não era, segundo Albers, um dado puro em si; suas aulas discorriam sobre os postes de luz de Nova lorque, sobre a anatomia de insetos, monumentos, etc., pois "o artista estava convencido de que nenhum elemento (seja ele da linguagem visual ou não) possa existir fora de um contexto".

Assim, em seu livro A interação da cor, de 1963, Albers apresenta seu conceito de educação com arte, "segundo ele pouco conhecido e cultivado na época: "pensar em situações". A proposta não é casual. Depois de se dar conta de que "a cor é o meio mais relativo dentre os utilizados na arte", Albers entende não fazer mais sentido que seus cursos se iniciem com a apresentação de sistemas e teorias da cor, passando a enfatizar a experimentação." ${ }^{8}$

Com a formulação de um ensino de arte baseado na experimentação - e de que esta não está nem um pouco descolada da vida, dos objetos, paisagens etc. - o lugar do professor é aquele que apresenta o problema e as situações-problemas a partir de experiências; os resultados serão compartilhados e desconhecidos por ambos, professor e aluno. Ou seja, trata-se de um processo de aprendizagem mútua.

As aulas de Albers (é possível assistir parte de seu trabalho como professor em um documentário silencioso disponível no site de sua fundação ${ }^{9}$ ) são enérgicas, os alunos andam pela sala, usam o corpo para desenhar um círculo no ar, afastam-se e aproximam-se pela linha do olhar de um objeto. Elas me fazem pensar que o interesse em destrinchar elementos da linguagem visual em si não colaboram para uma aprendizagem experimentadora em arte.

Albers se opõe ao que ele acredita ser a tônica da aula de arte, normalmente composta pela dupla teoria-prática, nesta ordem. Ao contrário disso, o "pensar em situações" pressupõe que "a prática não é precedida, mas sim seguida pela teoria", ${ }^{10}$ visando uma aprendizagem em arte pautada pela experiência. Curiosamente, apesar do caráter experimental e colaborativo da prática educacional de Josef Albers ter tido uma grande influência na arte-educação estadunidense, na literatura brasileira acerca da área há pouco reconhecimento do seu legado. Uma possível justificativa está no fato de que seu trabalho, a ver pelos seus escritos, está no embate constante

\footnotetext{
ALBERS,Joseph.In:Goldberg,Roselee.Aartedaperformance-DoFuturismoaoPresente.SãoPaulo:MartinsFontes,2006,p.111. HOROWITZ, Frederick; DANILOWITZ, Brenda. Josef Albers: to open eyes. Nova lorque: Phaidon, 2006, p. 90. HONORATO, Cayo, op. cit., p. 147

$\leftarrow$ http://albersfoundation.org/teaching/josef-albers/introduction/ $\rightarrow$. Acesso em 20/05/2015

ALBERS, Joseph. A interação da cor. São Paulo: WMF Martins Fontes, 2009, p. 92
} 
com a ideia de pesquisa, de ensino e de prática docente que ele propunha - o que não aparece como a tônica dos textos de arte-educação, especialmente após sua estruturação, entre 19801990, cujo foco parecia estar mais centrado no discurso que configurava elementos para se definir a arte como conteúdo e não que a pusessem em xeque.

Para Albers, o principal trabalho do professor de arte seria "to make open the eyes"11 algo aparentemente simples, mas de implicações complexas: ver com acuidade significa desaprender a ver por padrões pré-estabelecidos, estar aberto para o novo. 0 artista alemão, segundo relatos, era bastante rígido em relação a esse propósito, porém amável e aberto em relação ao processo de cada aluno.

Seus cursos eram, por sua própria opção, cursos introdutórios ou básicos, enfatizando que aprender a ver deveria preceder o trabalho do artista. Assim, Albers concluía que o que há de possível em ensinar arte residia em apreender profundamente através de um olhar sensível e atento os elementos da linguagem artística, sendo o restante inensinável e fruto do pensamento artístico de cada um. No entanto, ainda assim, a despeito do caráter experimental de seus cursos nos Estados Unidos, o trabalho de Albers foi transformado em uma série de exercícios reproduzidos em salas de aula e totalmente descaracterizados e desvitalizados do exercício de criação colaborativa que o artista propunha.

Deleuze, em uma analogia à gramática visual, diz que somos todos compostos por linhas, mais esquematicamente três tipos diferentes de linhas: a linha segmentária ou dura, a linha flexível e a linha de fuga ou nômade.

A primeira é a linha que corta nossa vida chamada linha rígida ou dura, dividindo-nos em homem/mulher, americano/africano, adulto/criança, branco/negro. Ela funciona por códigos binários que nos definem e identificam. Por essa linha se passa toda a segmentariedade que nos constitui: "de um segmento a outro, nos dizem: agora você já não é um bebê; e na escola, aqui você não é mais como em família; e no exército, lá já não é como na escola (...)".12

A segunda linha, flexível, está relacionada às pequenas mutações, aos devires e desejos; é de uma ordem mais imperceptível se for comparada com a linha dura: "Por isso são tão penosas as histórias de família, as referências, as rememorações, enquanto todas as nossas verdadeiras mudanças passam em outra parte, uma outra política, outro tempo, outra individuação". ${ }^{13}$ Já a última, a linha de fuga, diz respeito àquilo que nos faz fugir e escapar do mundo. É certo que há pessoas que não têm essa linha, ou não se deixa atravessar por ela. No entanto, tudo - e todos - é constituído de um grande emaranhado de linhas imanentes. Não há hierarquia nem moral sobre elas, ainda que a última pareça ser a melhor das linhas: cada uma delas tem seus riscos, perigos e qualidades. As linhas de fuga podem nos conduzir, por exemplo, à loucura, destruição e suicídio, mas, por outro lado, são elas que sempre impedem que os sistemas sejam homogêneos e monótonos.

Para Deleuze, as linhas estão constantemente em fuga, mas são surpreendidas pelas 
linhas duras e flexíveis. Porém, adverte Peter Pál Pelbart, "se essa cartografia tem um sentido pragmático, é precisamente o de avaliar os perigos e as chances de cada linha a cada momento. Trata-se de perguntar em cada caso, quais segmentos duros nos constituem e recortam nossas vidas, mas também quais outros estamos deslocando, inventando, e sobretudo quais os perigos se os fizermos explodir rápido demais". ${ }^{14}$

Sobretudo, o trabalho de acuidade em arte é da ordem do sensível, do afeto e da percepção. Assim, um ensino que privilegie as linhas e observe os planos de imanência, os volumes e suas qualidades, que enxergue, em suma, o movimento na e da matéria - ao invés de se propor a sistematizá-la em conteúdos, por vezes, desconectados da vida - tende a ser um conjunto simples, porém complexo, que tem dentro da aula de arte todo o escopo que recobre a vida. Pois "o que se procura ao pensar o que é a matéria das artes não é instituir programas formalizados, tampouco elencar conteúdos ou definir uma 'linguagem' e sim produzir a amostragem das variadas maneiras pelas quais é possível tratar uma matéria, inventando e aprendendo modos de ensiná-la". ${ }^{15}$

Por fim, de Albers a Deleuze, o "abecê" da aula de arte é muito vasto - o que quer que apresentemos como potência para a aula de arte que o seja no sentido de experimentação como recusa ao excesso de tecnicismo que envolve a educação como um todo. Investigar as linhas, os nós, os traçados que compõe as relações, os espaços, os alunos e as matérias, enfim "(...) pensar as coisas como conjuntos de linhas a serem desemaranhadas, mas também cruzadas.(...) Não é a linha que está entre dois pontos, mas o ponto que está no entrecruzamento de diversas linhas". ${ }^{16}$

Nesse sentido, uma aprendizagem em arte que leve em consideração a experimentação colaborativa, na qual professor e aluno são postos diante de situações-problema, possibilita que os alunos "não apenas encontrem soluções próprias para problemas conhecidos, como também visualizem e descubram novos problemas, novas soluções e novas apresentações". ${ }^{17}$ Haja visto que "não são os começos nem os fins que contam, mas o meio. As coisas e os pensamentos crescem ou aumentam pelo meio, é aí onde é preciso instalar-se, é sempre aí que isso se dobra".18

Para tanto, é preciso que haja sensibilidade do professor para lidar com as mais diversas linhas que compõem a aula, o outro e a si próprio, fazendo com isso composições que aumentem a potência de si e do outro, que façam ranger os elementos estáticos de uma arte sem latência para uma arte como experimentação de vida.

\footnotetext{
14 PELBART,PeterP.“Aartedevivernaslinhas”. In:DERDYK, E.Disegno.Desenho.Desígnio.SãoPaulo:Senac,2007, p.286 15 ZORDAN,Paola.Percursosdasartesvisuais: geologiadeumadisciplina. Disponívelem: $<$ http://33reuniao.anped.org. br/33encontro/app/webroot/files/file/Trabalhos\%20em\%20PDF/GT24-6006--Int.pdf $\rightarrow$. Acesso em 03/06/2015.

16 DELEUZE apud PELBART, Peter P., op. cit., p. 288.

17 ALBERS, Joseph. A interação da cor, São Paulo: Martins Fontes, 2009, p. 100.

18 DELEUZE apud PELBART, Peter P., op. cit. p. 288.
} 
$410=2 x+1$

the

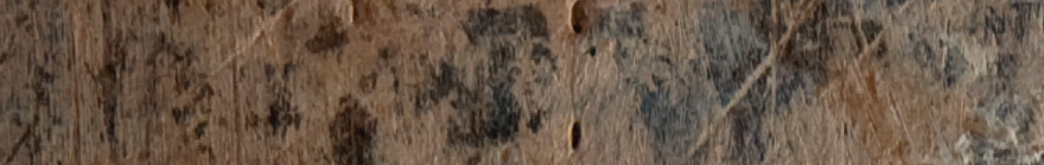

$x-2-1, x-4$

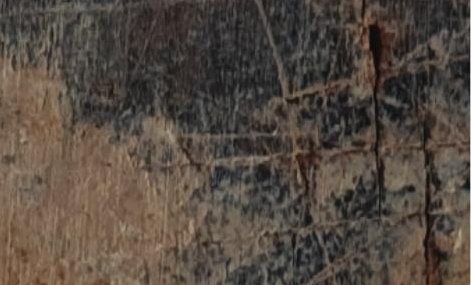

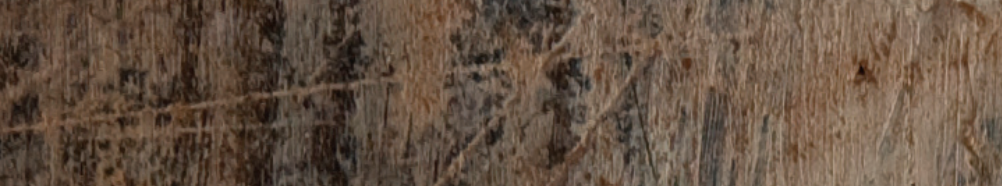

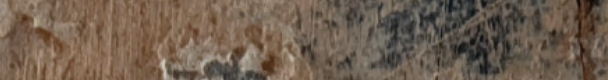

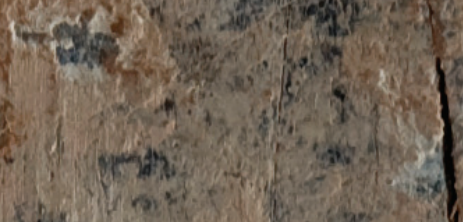

(3)

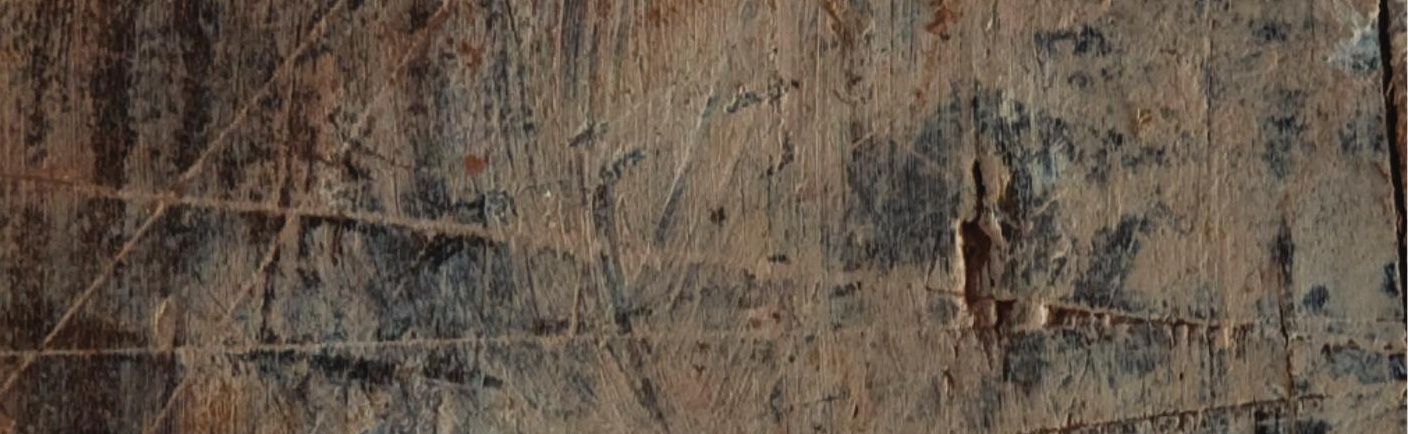

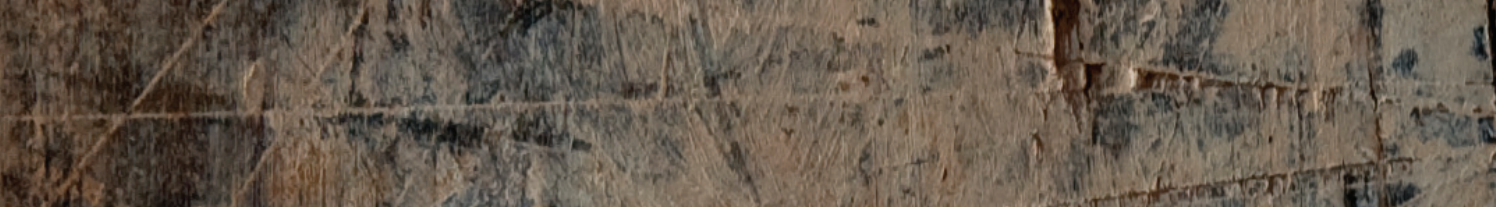

$x^{7} y^{2}-2$

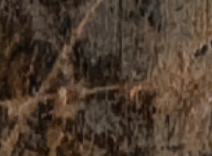

(x) $x^{2}+x^{2}$

$\left.(x)+x^{2}\right)^{2}$

Tex:

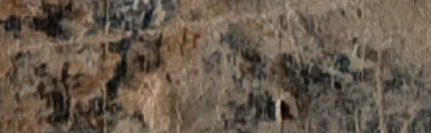

of

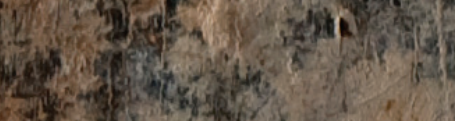

52

if

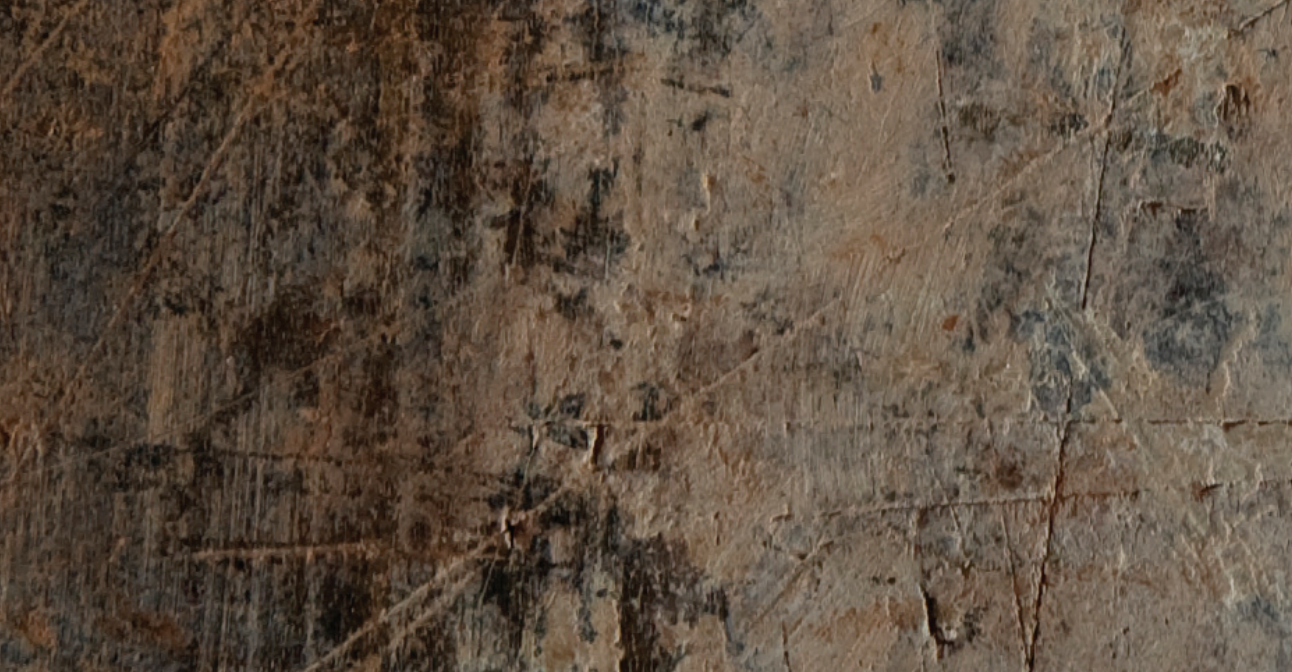

(3)

6) 65

$\operatorname{li}_{2} 2 x+10$

$x^{2}-2+x+2=2$

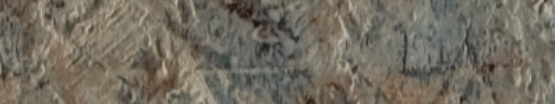

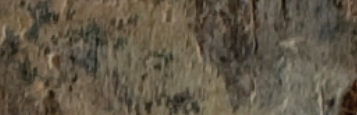

6ongen:

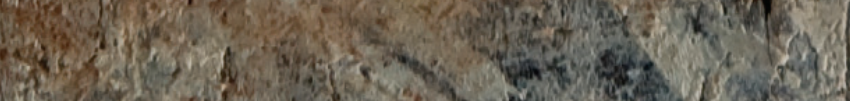

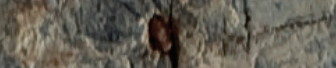

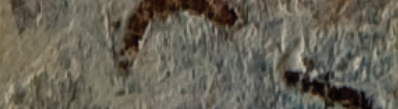




\section{Cadernos do olhar}

Como um desafio inicial, diagnosticado logo no início da minha docência, a aula de arte pressupunha, de partida, exercícios de desenho. Pela vontade de usar o desenho para operar uma dobra nele mesmo e transbordar o que dele se sabe na escola, armei um dispositivo chamado Cadernos do olhar.

O Cadernos do olhar funcionava como uma espécie de di[cion]ário ${ }^{1}$ composto de verbetes de $A$ a $Z$ de tudo o que acontecia nas aulas de arte: desde o contato com algum novo material ou procedimento até aquilo que se pode aprender com artistas estudados nas visitas a exposições. Cada prática resultava em um processo de escrita - batizado de "escrita lúdica" partindo da palavra como desenho (poesia concreta). Cada texto era criado pelo aluno, levandose em conta o que e como escrever, que materiais e técnicas utilizar, na tentativa de aproximar forma e conteúdo.

Esse experimento durou dois anos, sendo que no primeiro ano a escrita ainda não havia se apresentado como um campo de experimentação, embora a preocupação com o projeto visual de cada página fosse uma das premissas do trabalho. Em alguns casos, a experiência da relação entre texto e papel foi surpreendente e sinalizou a necessidade de pensar em como introduzir a escrita como uma questão da arte dentro da proposta.

Assim, no ano seguinte, resolvi manter a proposta dos Cadernos do olhar, e experimentar diferentes maneiras de desautomatizar a escrita, já que nos trabalhos iniciais dos alunos, ainda que partissem de folhas em branco, estavam extremamente condicionada à pauta dos cadernos e à caligrafia. $\mathrm{O}$ que me interessava nesse trabalho era justamente operar com aquilo que, de certa forma, parece ter sido banido do processo de alfabetização, já que, ao menos onde trabalho, a padronização da caligrafia se sobrepõe à experimentação artística que o desenho da letra pode proporcionar.

Para Jorge Ramos do Ó, historiador português, a escrita, na esteira do pensamento foucaultiano, poderia constituir uma ética da existência, sendo a escritura uma forma de desprendimento de si. No entanto, ao que parece, escrever, na educação, está frequentemente relacionado à cópia ou estritamente vinculado à leitura e à divinização dos autores. ${ }^{2}$ No meu caso, eu gostaria de enfatizar a plasticidade da escrita e do texto sem ater-me ao processo de escrita em si.

Dessa forma, ao iniciar o Cadernos do olhar no ano seguinte, decidi trazer como referência a poesia concreta. Entretanto, logo percebi que seria ampliar demais o escopo de conteúdos tratados. Usei apenas como referência alguns conceitos dos poetas concretos, como a importância do espaço gráfico, a tensão entre palavra e sentido, a amplificação dos significados, ${ }^{3}$

\footnotetext{
1 Seria um dicionário por englobar tudo que poderia ser criado em aula, mas também seria um diário, espécie de inventário do processo de aprendizagem de cada aluno, por isso o termo di[cion]ário.

2 Ó, Jorge Ramos do; Costa, Marisa. Desafios à Escola Contemporânea: um diálogo. Entrevista concedida à Revista Educação \& Realidade, v.32, n.2, p.109-116, jul./dez. 2007. p.111.

3 CAMPOS, A. e H. PIGNATARI, Décio. Plano-piloto da poesia concreta. 1958. In: www.poesiaconcreta.com. Acesso em 25/05/2013.
} 
sem tratar da história e procedimentos da poesia concreta em si.

Nas pesquisas sobre o tema, chegamos a um livro infantil chamado Letras lúdicas, ${ }^{4}$ cujo conteúdo, de uma forma lúdica, como o próprio título promete, trata da relação entre escrita e desenho, significado e significante. As imagens do livro ilustraram e sensibilizaram uma introdução ao tema que eu pretendia: pensar cada página do caderno como um espaço de criação próxima ao design e usar a palavra e o texto elevando em consideração o seu conteúdo.

Com o passar do tempo, a metodologia do trabalho, ainda que empírica, ficou mais clara para mim e, consequentemente, para meus alunos. Eu sabia que deveria partir da escrita como elemento plástico, e do papel como campo visual. Nesse sentido, iniciei o trabalho com uma sequência didática que experimentava a palavra de forma lúdica, a fim de estabelecer uma compreensão dela como elemento da linguagem visual, fazendo uso do desenho como técnica.

Assim, aquela ideia convencional de aula de arte como espontaneidade e livre expressão deu lugar a uma metodologia de trabalho bastante clara. Com isso, pude perceber que, já ao final do primeiro trimestre, o aluno, mais consciente do seu processo, passou a agir de forma mais autônoma em relação ao próprio trabalho, tomando notas e pesquisando por conta própria, e criando projetos visuais cada vez mais ousados. Ao verem seus verbetes completos e encadernados, os alunos pareciam ter uma sensação de completude em relação ao que haviam aprendido. Eu também tinha a consciência de que aquele material produzido poderia futuramente servir de fonte de referências e experiências concretas. Ou seja, tratava-se de algo que o aluno poderia levar consigo.

Acredito que o grande trunfo desse longo processo foi justamente o lugar inesperado que a escrita ocupou na aula de artes visuais. Com o dispositivo criado, além da libertação da escrita, senti que rumamos para uma relação mais prazerosa com os próprios processos intrínsecos à escritura.

Os alunos passaram então a se entusiasmar com suas produções e as dos colegas, e se surpreendiam com o modo como cada um podia sistematizar e ocupar o espaço branco da folha de maneiras tão diversas, trazendo à prática da escrita algo da ordem da brincadeira, extrapolando a representação e os significados, definindo de forma marcante as singularidades do processo de cada aluno em um "movimento novo e puro da escrita, que extraía do escrever como evento a sua energia". 5

Os dois anos da proposta Cadernos do olhar abriram uma possibilidade de criação processual de longa duração, muitas vezes deficitária nas aulas de artes visuais, especialmente com alunos entre onze e doze anos correspondente ao ssexto ano. Mas, para além da sala de aula, essa proposição, ainda que experimental, foi uma maneira que encontrei de configurar aquilo que entendia como o meu trabalho docente: uma construção permanente de um acervo para ser manipulado e transformado de diferentes formas e combinações. Essa pesquisa é um 
exemplo da constituição deste acervo; a combinação e escolha dos verbetes engendra um dos possíveis encontros entre sala de aula, arte e pensamento.

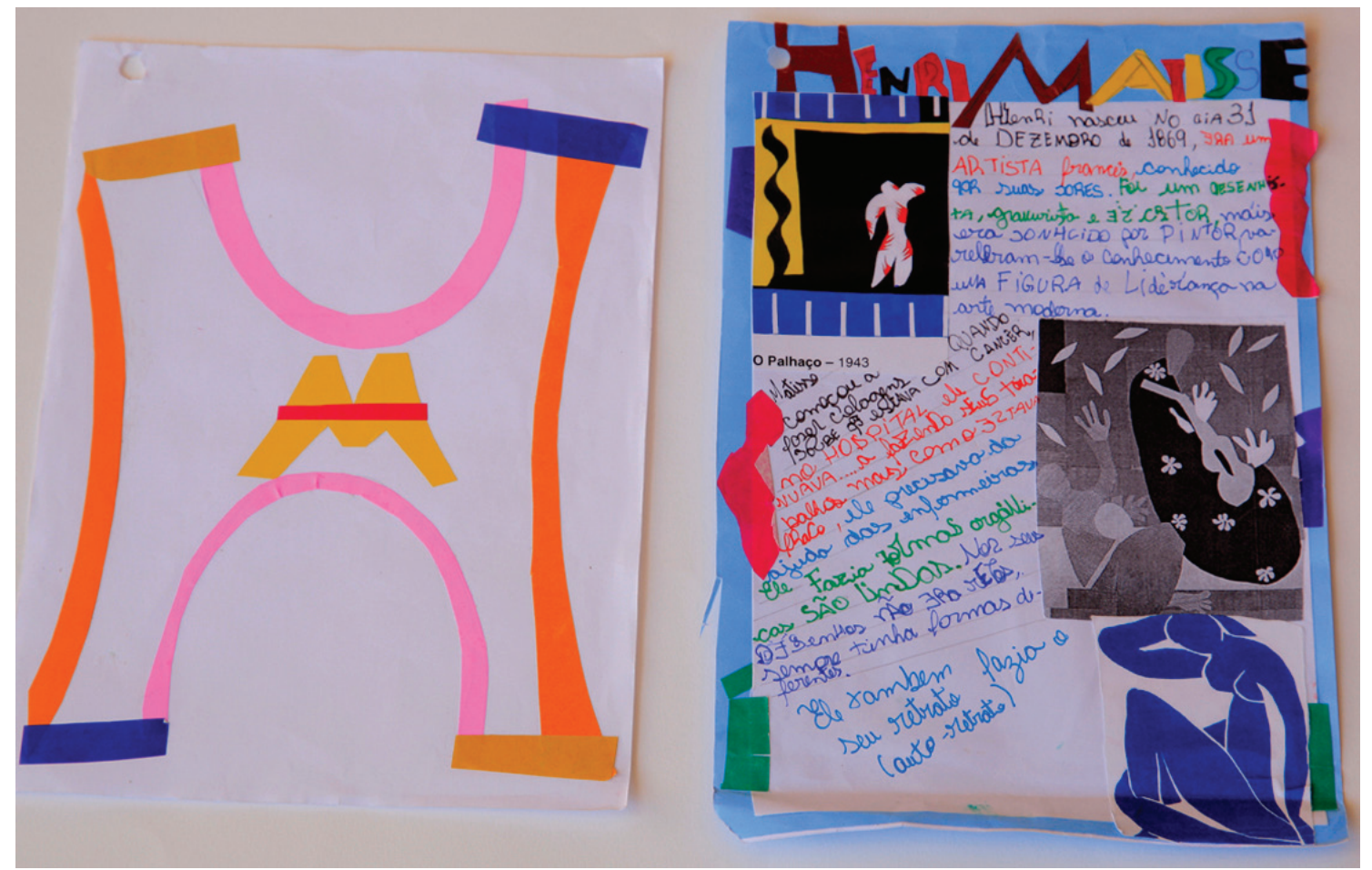

Exemplo de verbete do Caderno. Fonte: própria, 2013. 


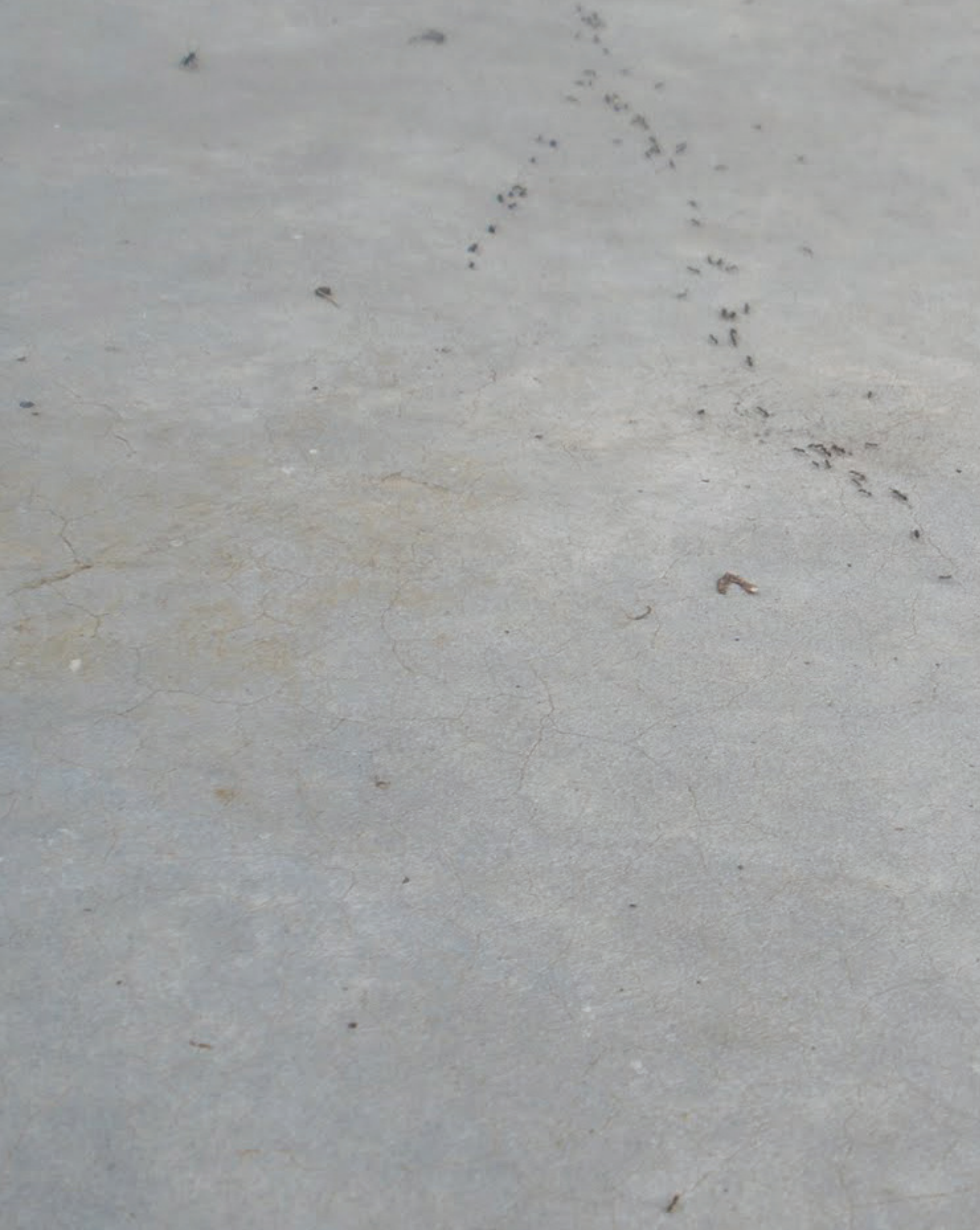




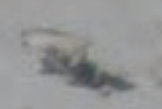

a

7

53

is 1

$\sqrt{1}$

$\frac{5}{\infty}+4$

s.

Deseninanças 



\section{Desenho como caminho}

Se na história da arte o desenho sempre se manteve como coadjuvante, sendo considerado autônomo apenas no século $X X$, nas aulas de arte ele é, possivelmente, o personagem principal. No Ensino Fundamental I, o desenho é diversão, já no Fundamental II e Ensino Médio, ele é detestado (a não ser por aqueles alguns que adoram desenhar e que tem o reconhecimento de "saber desenhar").

A palavra desenho é derivada do latim - de (fora) signum (marca, sinal) -, e sua acepção no português conserva bem a ideia do desenho como uma ação, como produção de um sinal (de-signo). Porém há outras acepções, como no inglês e no francês, que operaram uma separação entre o ato do desenhar como projetar e o desenho como finalidade (drawing/design ou ainda dessein/dessin).

No entanto, independente da separação ou não do desenho/desenhar, no ambiente escolar, construir com os alunos a ideia de desenho como uma forma de pensamento visual - do esboço ao trabalho de expressão, não é uma tarefa fácil. No geral, o desenho está relacionado ao produto final e preferivelmente ele deve livre. Entretanto, percebo que há uma grande dificuldade de entender o desenho como processo e quando entendido como pensamento, o desenho está sempre direcionado ao lápis e ao papel.

$\mathrm{Na}$ tentativa de experimentar o desenho como um suporte de criação, para além do papel, tenho desenvolvido o projeto Desenhanças, iniciado em 2010 no Centro Cultural São Paulo. Naquela ocasião propus uma série de oficinas que usava o espaço daquele equipamento cultural como suporte para o desenho: paredes, vidros, banheiros, chão, elevadores recebiam pequenas intervenções no espaço ativadas através de andanças por aqueles lugares.

Depois de iniciada a minha vida docente, em chão de sala de aula, muito me incomodava a hegemonia do desenho nas aulas de arte. ${ }^{1}$ Não obstante, eu ter uma longa história desde a infância com o desenho (o desenho foi o meu melhor amigo, lugar de fantasia e fuga), me interessava propor uma outra entrada para o desenho na sala de aula. Desta forma, me propus a continuar com o projeto Desenhanças, desta vez no contexto escolar.

É sabido pela vasta literatura em torno do desenho da criança, seja por perspectivas cognitivistas (lavelberg, 2006), ou sobre o espaço de representação (Moreira, 1987), ou ainda do desenho como construção de conhecimento (Pillar, 2006), que a exploração desse tema é infindável e passível de ser feita a partir das mais variadas abordagens. Os usos mais habituais e reconhecidos do desenho, de forma genérica, poderiam ser divididos em dois tipos de abordagem: uma calcada numa visão tradicional do desenho, e disso derivam as práticas de desenho de observação, natural, pedagógico (aquele desenho que sempre tem nas avaliações de todas as outras disciplinas, como ilustração do que se aprendeu). Nesse universo perspectivas, 
luz e sombra, proporcionalidade são conteúdos imprescindíveis. Por outro lado, há a concepção de desenho impregnada pela pedagogia nova: livre, genuíno, desenvolvimento da criatividade, centrada nos aspectos psicológicos. Disso resultam as práticas de desenho cego, desenho de memória, desenho livre, desenho para análise psicológica, e etc.

Pode-se afirmar que, hoje em dia, essas duas tendências que já foram antagônicas operam juntas na sala de aula. Não digo isso baseada em uma pesquisa vasta, mais uma vez, tenho como dado o discurso dos meus alunos e o trabalho que vejo e desenvolvo na escola.

Apesar do desenho poder ser analisado a partir das mais variadas abordagens, neste caso, tendo em vista o meu objetivo inicial: a proposição de uma outra entrada para o desenho na sala de aula, me preocuparei em refletir sobre o desenho fora das categorias já demonstradas, sem com isso querer desmerecer a importância dessas abordagens e tampouco do desenho como prática artística - do esboço, da sistematização de ideias à noção de um tipo específico de pensamento. Não se trata, portanto, de discorrer sobre a sua especificidade, mas sobretudo, de percorrer uma linha, na qual o desenho possa assumir lugares impensados na escola.

Essa inquietação em relação ao desenho e seu uso tão banalizado na educação me fez encontrar parceiros de percurso, como por exemplo, a artista e educadora Edith Derdyk, cujo trabalho além de estar na interface entre arte e educação apresenta uma preocupação em pensar o desenho para além dos moldes tradicionais.

Para a artista e educadora, o desenho é um lugar de diferentes experiências, não exclusivas à arte, mas que atravessa também a ciência, a técnica e outras áreas do conhecimento. A artista se diz interessada em recuperar o significado do ato de desenhar como também "atitude"², a fim de realçar seus percursos inusitados e transitivos." ${ }^{\text {"3 }}$

O trabalho de Edith extrapola não raramente o papel e o lápis, seus desenhos tomam volume no espaço como na série Linhas de costura (1997), na qual a artista literalmente usa quilômetros de linha de costura e desenha com elas entre-paredes, dando visibilidade para a materialização da linha.

Nesse sentido, venho desenvolvendo trabalhos com desenho, desde pequenas experimentações, como diferentes tamanhos, gramaturas e texturas de papéis, diferentes materiais, até inflexões mais conceituais como pensar o desenho da palavra - como nos Cadernos do olhar e em uma sequência de ressignificação da palavra e da imagem - via Duchamp, Magritte, Detanico Lain, Jenny Holzer e poemas concretos - com 10 ano do Ensino Médio. Além de proposições que experimentam o desenho por outras entradas: seja pela ocupação do espaço, pela cartografia, seja pela ideia de deriva.

\section{Do desenho no campo expandido}

Inicio o ano perguntando aos meus alunos do 40 ano o que é desenho, e não me surpreende que todos tenham dado respostas que remetiam ao lápis e ao papel. Desse ponto 
de partida, a fim de ampliar a noção de desenho e seus suportes, saímos para desenhar no alambrado da escola com linhas de lã, e depois disso no chão da escola com gizes, e depois nos azulejos dos banheiros. Cada proposta estava atrelada a uma narrativa que era construída coletivamente por meio de desenhos.

O mesmo trabalho de reconhecimento do espaço do desenho como algo maior que o campo do papel, feito com as crianças de nove anos, recorrentemente, é feito também com os adolescentes de quinze anos que, ao entrar no ateliê de Artes Visuais, descrevem como primeira intenção naquele espaço "aprender a desenhar" ou continuar a desenhar (para aqueles que julgam que já desenham muito bem - dentro do representacional), já que para essa série é possível optar qual modalidade artística (artes visuais, música ou teatro) cursar. Dou em suas mãos um novelo de linhas emaranhadas para que juntos desfaçam o novelo e em seguida desenhem. Como? Mas, cadê o papel? Pode colar com fita na parede? A única recomendação é que ocupem o espaço.

Desse desenho que avança sobre o espaço, nascem inúmeras questões que servem de pano de fundo para a prática no ateliê ao longo do ano. O uso recorrente de papel de diferentes tamanhos é um outro dispositivo que, além de causar estranhamento, convoca os alunos a refletirem sobre o desenho que sair daquilo que eles reconhecem: papel e lápis. São configurações de experimentos, tais quais as situações-problema de Albers. São os materiais como disparadores de problemas e não como meio de chegar aos resultados - ou seja, uma subversão dos meios que naturalmente são apresentados nas aulas de arte como dados estáveis - lápis é para desenhar, guache para pintar, argila para modelar e por aí vai.

\section{O desenho como deriva}

Bastante presente no trabalho de arte contemporânea, - mais especificamente, na performance - a ideia de deriva como processo artístico, certamente é herdeira da flânerie baudelariana, cujo objetivo é uma relação contemplativa com o espaço. Conceituada pelos situacionistas, especialmente por Guy Debord, o conceito de deriva "está ligado indissoluvelmente ao reconhecimento de efeitos da natureza psicogeográfica, e à afirmação de um comportamento lúdico-construtivo, o que se opõe em todos os aspectos às noções clássicas de viagem e passeio."4

Me interessava transpor essa noção para o ambiente escolar, e com isso pensar de que forma o espaço pode ser disparador de afetos?

A partir dessa questão, com os alunos formandos do $3^{\circ}$ ano do Ensino Médio, me inquietava a falta de qualquer trabalho que ritualizasse de alguma maneira o final do longo processo de escolarização pelo qual eles passaram.

E partindo da deriva e da ideia de cartografia proposta na introdução do primeiro volume dos Mil Platôs de Deleuze e Guattari, venho propondo um processo de construção espacial por meio do desenho e de intervenções na escola cujo objetivo está na constituição de uma espécie

4 DEBORD, Guy. Teoria da deriva. Texto publicado no n ${ }^{\circ} 2$ da revista Internacional Situacionista em dezembro de 1958 Segunda tradução (espanhol - português) por membros do Gunh Anopetil em 19 de março de 2006. Disponível em: https:// teoriadoespacourbano.files.wordpress.com/2013/03/guy-debord-teoria-da-deriva.pdf. Acesso em 20/07/2015. 
de cartografia afetiva das histórias vivenciadas no ambiente escolar.

O conceito de cartografia aparece como um dos princípios do rizoma. Em oposição ao decalque e ao mapa, a cartografia é um processo no qual "não há um único sentido para a sua experimentação nem uma mesma entrada. São múltiplas as entradas em uma cartografia. A realidade cartografada se apresenta como mapa móvel, de tal maneira que tudo aquilo que tem aparência de "o mesmo" não passa de um concentrado de significação, de saber e de poder, que pode por vezes ter a pretensão ilegítima de ser centro de organização do rizoma. Entretanto, o rizoma não tem centro." ${ }^{\prime 5}$ Ou seja, a cartografia funciona como método para a composição desse desenho de percurso que se constitui em ato e a partir dos afetos que o atravessam, tendo necessariamente a deriva contemplativa como instrumento desencadeador dos afetos.

A Escola de Aplicação da FEUSP tem uma peculiaridade interessante em relação às outras escolas, pois as vagas são preenchidas no $1^{\circ}$ ano do Ensino Fundamental e como há uma taxa de evasão extremamente baixa, os alunos seguem juntos durante os onze anos da escolarização deles. Assim, o espaço escolar é preenchido de memórias conectando diferentes grupos em diferentes fases deste processo.

Tendo isso em vista, cada aluno deveria caminhar pelo espaço da escola tentando marcar as suas memórias com giz de lousa, fitas adesivas coloridas e papéis a fim de deixar novas marcas nesses espaços. Esses vestígios deveriam ser compartilhados com o grupo, porém ao invés de relatá-los, eles deveriam ser re-encenados.

Essa proposição, assim como a sua continuidade foram inspiradas pelo filme do premiado diretor japonês Hirokazu Kore-eda chamado Depois da Vida. Nesta ficção, após a morte, pessoas passam por um estágio que antecede a eternidade (que se define por uma única memória da vida) tendo que decidir qual será a memória a ser levada. Pa ra então, criar o roteiro e filmá-la.

A gravação dessa cena inspira a re-encenação das memórias que compõe o percurso que denominei "autobiocartográfico" de cada aluno. Cada vestígio marcado ativa uma presença do corpo daquele que está revisitando sua memória, amplia os vínculos dele com sua história e com seu grupo.

Depois dessa investigação e constituição de uma cartografía coletiva dos afetos deste pequeno grupo do ateliê de artes visuais partimos para a abertura de uma entrada também para os outros alunos do $3^{\circ}$ ano que estão nos ateliês de teatro e de música, sob a pergunta: se você tivesse que escolher uma única cena para levar daqui da escola qual seria? Com a gravação de áudio e/ou vídeo dessas falas compunham-se parte do filme de fechamento da escola que era exibido na formatura dessas turmas.

Com Desenhanças, abre-se um espaço de maior intersecção do desenho como pensamento artístico e portanto comprometido com uma experimentação para além de seus suportes tradicionais. Entendido como afeto, memória, palavra, o desenho torna-se aquilo o que

5 PASSOS, E. KASTRUP,V.ESCOSSIA, L(orgs.).Pistassobre o método cartográfico: pesquisa-intervenção e produção de subjetividade. Porto Alegre: Sulina, 2009. p. 10. 
aproxima de sua acepção original - um desígnio, uma marca e um desejo que se projeta, se esboça no espaço.

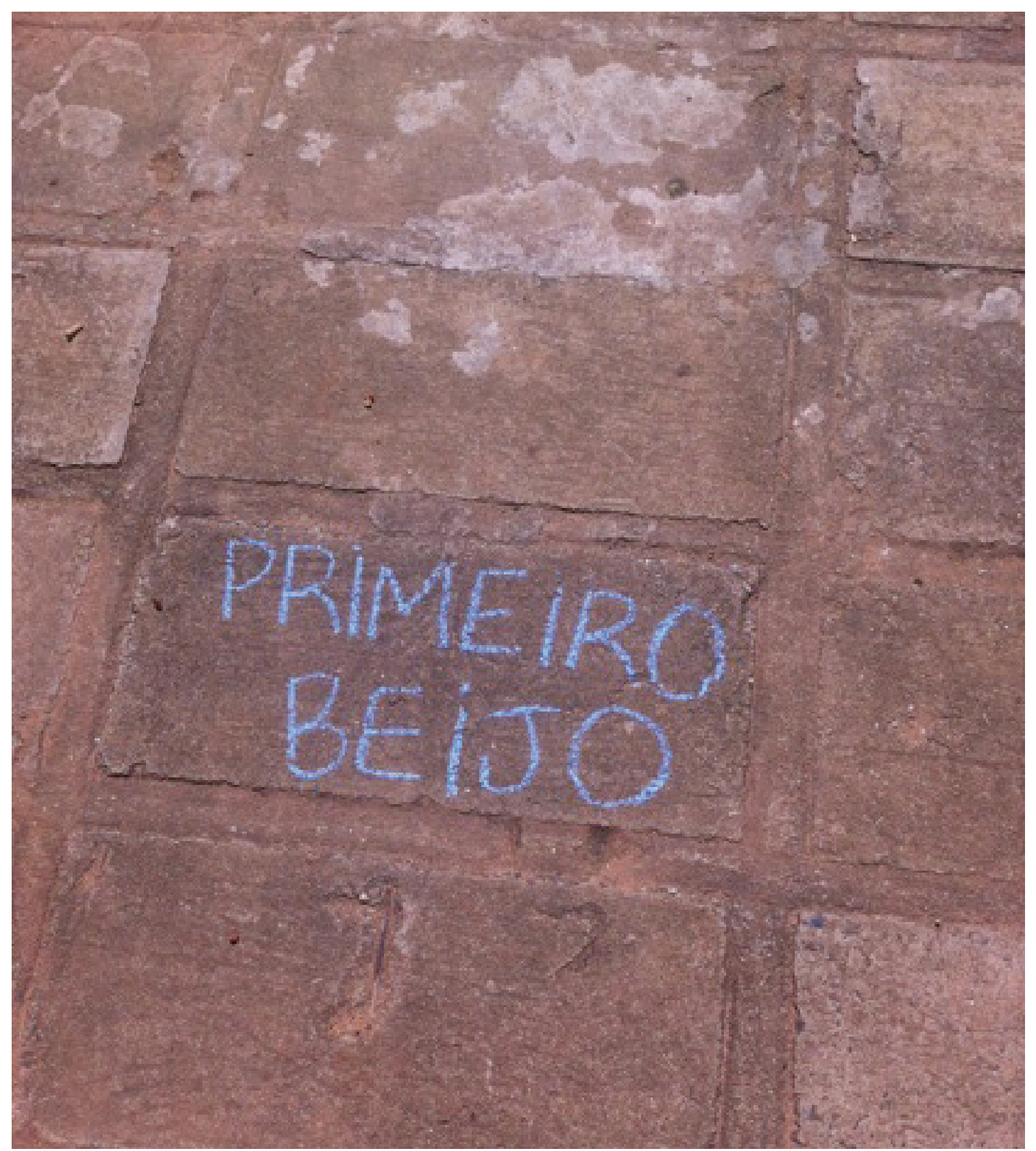

Fotografia do vestígio/memória de uma aluna. Fonte: própria, 2014. 
$x^{2}+2=2$

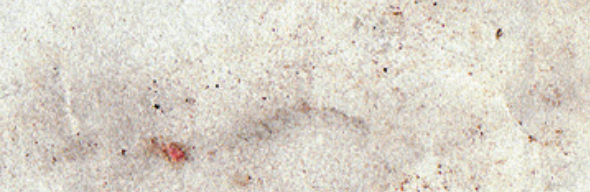
$(x+2)=$

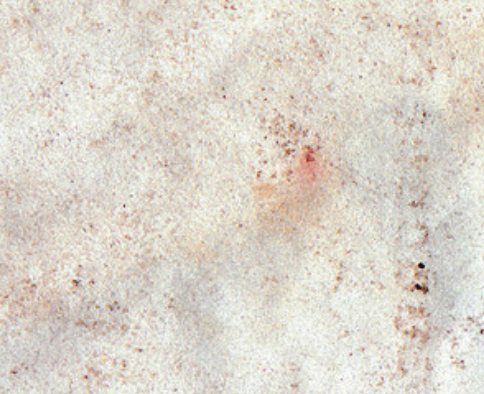

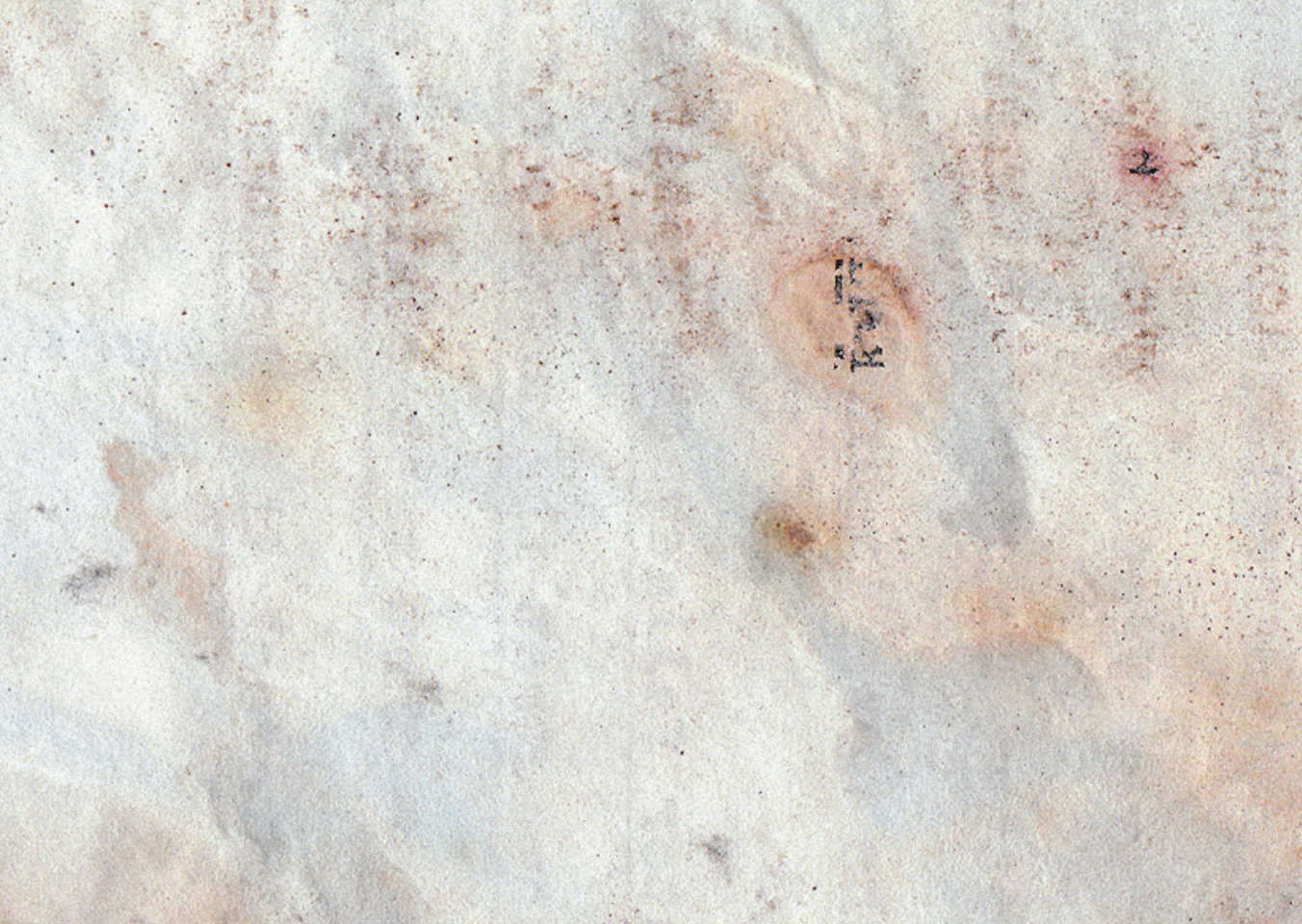

(c)

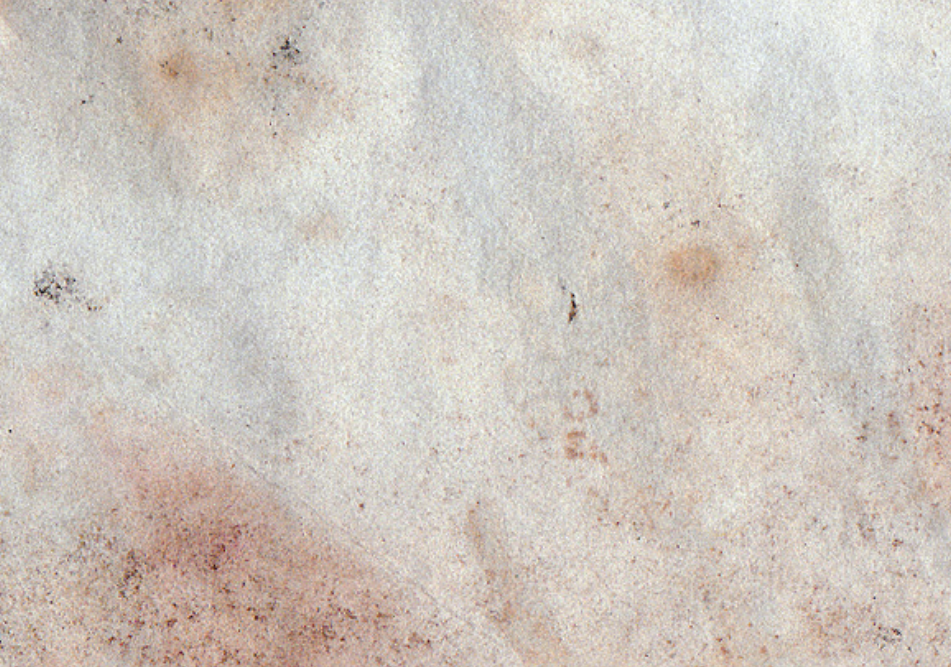
$x^{2}$ 


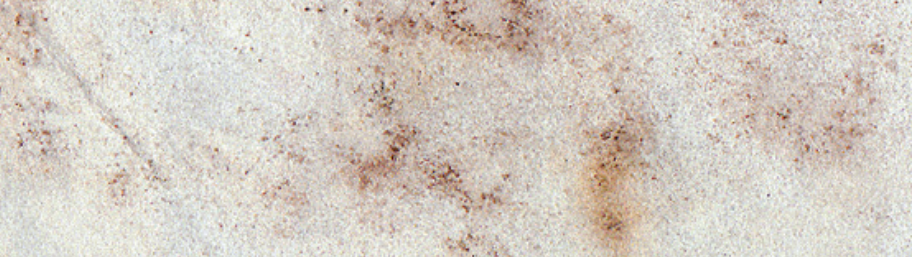
(3) $40=2$

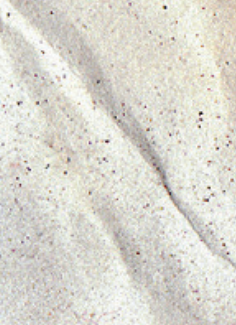

$+2$

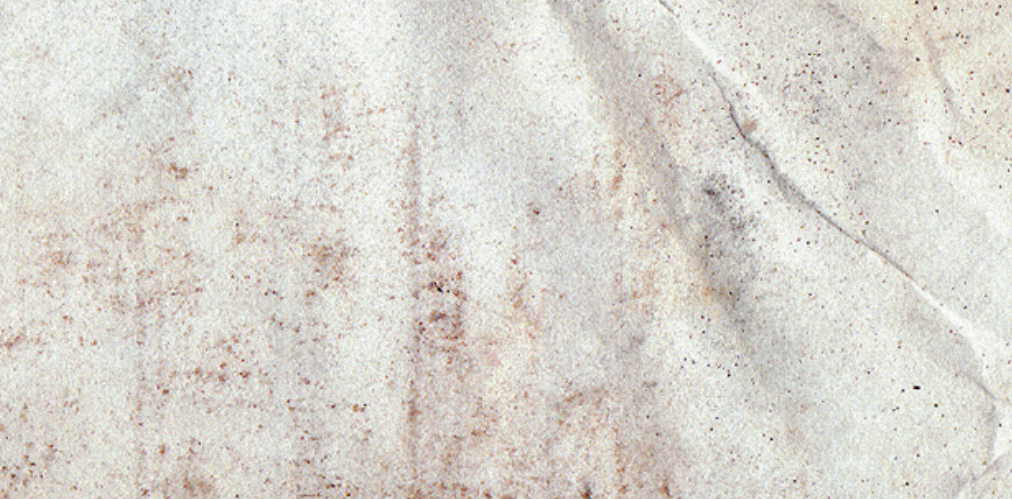

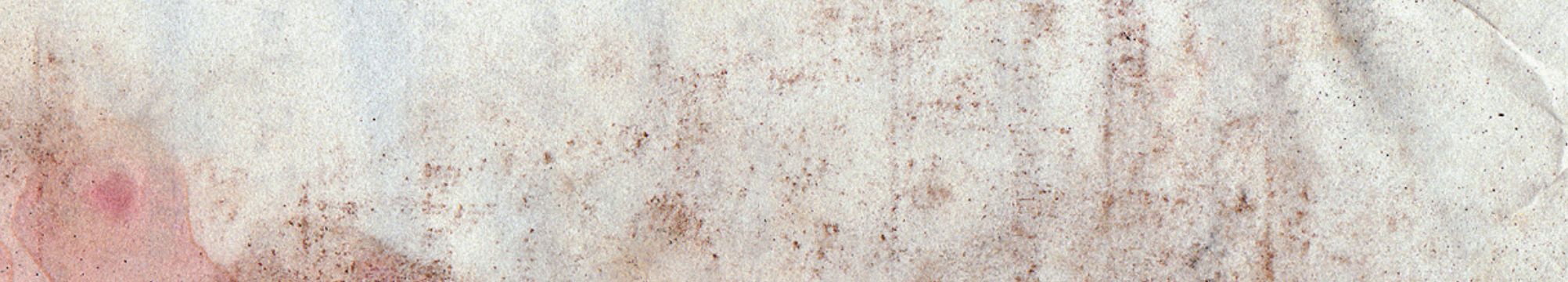

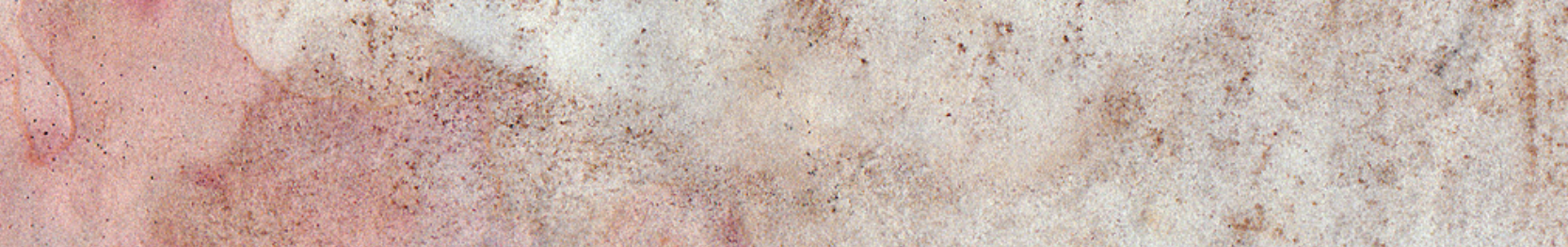

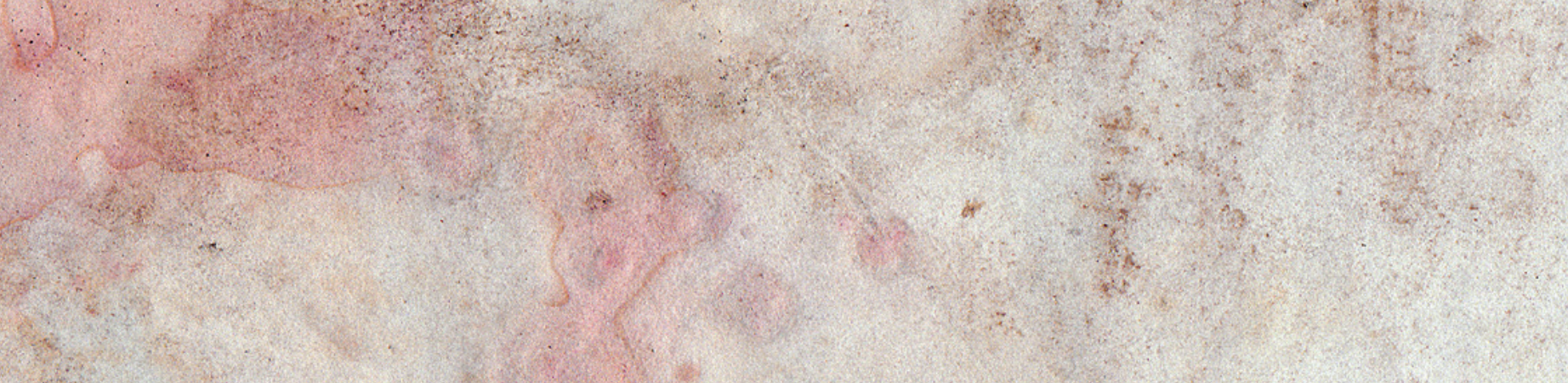

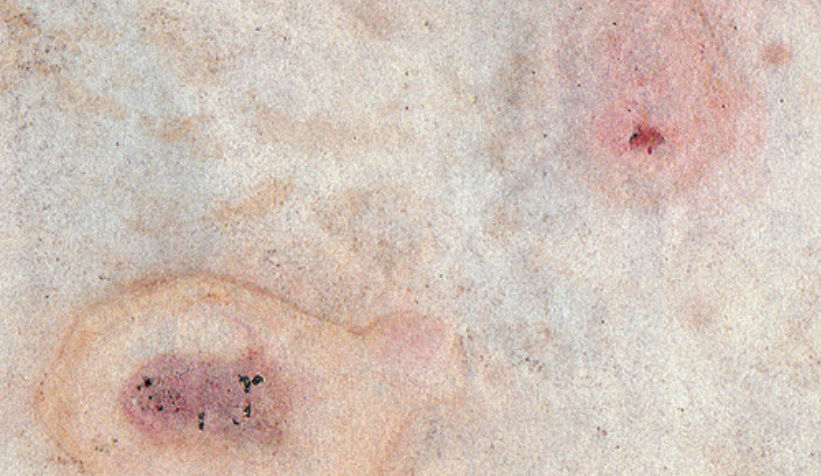

(.8)

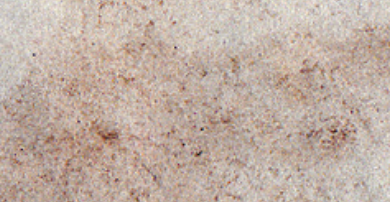

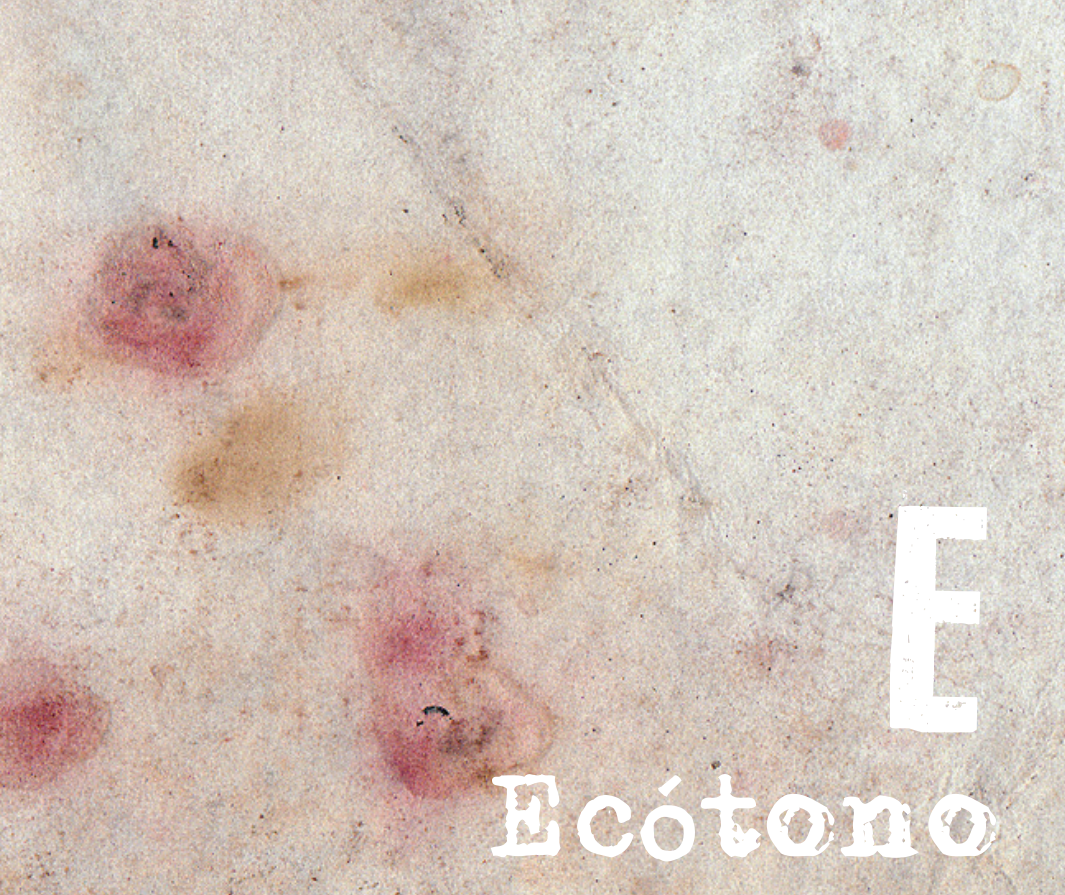

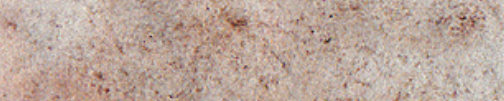

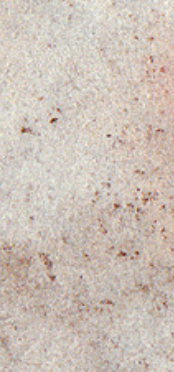
(x)

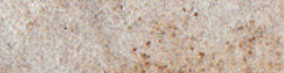

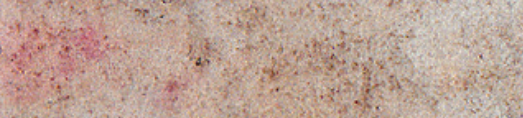

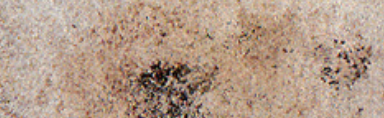

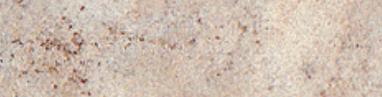


Ressignificar, realocar, referenciar, tomar de empréstimo, roubar - o que não tem nada a ver com copiar, imitar ou plagiar, são procedimentos comuns tanto às práticas artísticas contemporâneas quanto à filosofia da diferença. Pode-se perceber que todos os verbetes e tudo nesta pesquisa é simpático ao pensamento de Deleuze, visto que "uma teoria é como uma caixa de ferramentas. Nada tem a ver com o significante... É preciso que sirva, é preciso que funcione. E não para si mesma.(...) ${ }^{\prime \prime}$

Simpatia, da etimologia grega - de syn (com) e pâthos (sentimento, experiência, sensação) $)^{2}$. Ou seja, uma experiência compartilhada, uma partilha de um modo de pensar. Trata-se de uma negativa: nega-se a mesmice da cópia, da representação e busca o informe, o impensado através de movimentos, intensidades, capturas, devires.

Simpática à ideia de poder fazer da escrita e da prática docente lugares de contágios e de criação, onde pensamentos advindos das mais diferentes áreas do conhecimento transitem e sejam capazes de produzir outros planos de consistência. Nas deambulações do percurso, topei com o ecótono, um conceito da ecologia, que prontamente pareceu servir para propor uma outra inscrição da arte na educação:

Um ecótono é a zona de passagem de um bioma a outro; por ex., entre a floresta e o campo há uma zona de passagem: a mata de arbustos. Neste local, normalmente a diversidade de espécies é muito maior do que as espécies de cada bioma separadamente. É nesta zona de contato que as trocas e o embate entre espécies diferentes ocorrem na tentativa de partilhar o mesmo espaço. É da relação entre biomas e da adaptação a este local e contato que nasce o ecótono como interface entre as duas comunidades. A tendência ao aumento da diversidade e o aparecimento de organismos resultantes desta zona de passagem (e que só são encontrados aí) é chamado de efeito de borda. ${ }^{3}$

Ainda que o território da arte-educação já esteja bem constituído, há uma insistência enorme nos textos da área em operar na sua constante reiteração, um convencimento da importância da arte na educação. $O$ fato é que há algo que se passa no encontro entre os dois termos que parece difícil de tatear, tem algo de imaterial, volátil, nem-uma-coisa-nem-outra, e é justamente esse componente que liga uma parte à outra que é alvo das mais diversas teorizações, ora como forma de elevação estética, ora como instrumento pedagógico de desenvolvimento

1 DELEUZE, G. FOUCAULT, M. Os intelectuais e o poder. In: FOUCAULT, Michel. Microfísica do Poder. org., intr., revisão técnica de Roberto Machado, Rio de Janeiro: Graal, 1993. p. 43.

2 KOHAN, Walter. Entre Deleuze e a educação: notas para uma política do pensamento. Revista Educação e Realidade. Porto Alegre: v.27. ano 2. 2002. Disponível em: http://seer.ufrgs.br/educacaoerealidade/article/view/25922. Acesso em 28/02/2015. p. 124.

3 ODUM, Eugene. Ecologia. Rio de Janeiro, RJ: Ed. Guanabara, 1988 
criativo e nas escola, não raras vezes, como momento de lazer.

Facilmente a arte é destituída de suas especificidades para servir como ferramenta, ser recheada de conteúdos e perder o que é o seu próprio - a invenção, um tipo de pensamento que difere das funções e os conceitos e opera no sensível. Pensar a arte como um bioma próprio e a educação como um outro pode nos permitir que uma não seja subjugada à outra.

Nas últimas décadas temos assistido a um aumento significativo dos programas educativos em museus e espaços institucionalizados da arte, "segundo Ana Mae Barbosa, compete à arte-educação: tornar a arte acessível a um público cada vez mais diversificado, conquistá-lo para a arte, facilitar a comunicação e a apreciação desse público(...). Além disso, e o que parece reforçar a última dessas competências, um propósito da Abordagem Triangular naqueles lugares éencontrar um "equilíbrio" entre, de um lado, as necessidades e os interesses do público e, de outro, os conteúdos a serem aprendidos e a integridade da arte em sua autonomia."

No entanto, a autonomia da arte neste caso está, frequentemente, associada ao discurso hegemônico do curador, do museu e a serviço da manutenção do privilégio cultural e econômico da arte, "ou ainda em suplemento do currículo escolar, esquecendo-se de que a arte implica outra maneira de se haver com o mundo."5

Apesar desse inflacionamento de práticas educativas nos espaços culturais, é na chave proposta pela educação formal que fica ainda mais evidente como os discursos em torno da arte na educação configuram uma relação de dependência entre estes termos. Ora, se "essa reivindicação subordina a perspectiva da arte, melhor dizendo, a independência da arte como variável da relação à mera utilização de estratégias no campo da educação,"6 é preciso tentar operar na disjunção dessas partes e ver na escola a zona de passagem onde encontramos partes de cada um desses biomas. Não obstante, é onde também há o florescimento de algo que não é mais pertencente à nenhum dos biomas originários. Ou seja, não se trata de querer manter uma suposta autonomia da arte na escola ou pedagogizar a arte para caber na educação.

A escola será, portanto, adotada como a zona de passagem - o ecótono, no qual se dão as relações entre uma certa educação e uma concepção de arte, tendo em vista que, é no interior da escola que acontecem os afloramentos da arte e dele crescem outras significações capazes de romper com os padrões cotidianos prescritos por uma educação normatizadora.

A escola como ecótono se insere no regime do pensamento proposto pelo pensador francês Félix Guattari, ao qual dá o nome de ecosofia.?

A ecosofia é uma articulação ético-política frente ao mundo que parte de um conjunção de esferas atuantes sobre o nosso planeta, as quais Guattari denomina "três registros ecológicos": relações sociais, meio ambiente e subjetividades humanas.

Para o pensador francês, apenas com uma tomada de consciência do funcionamento

HONORATO, Cayo. A formação do artista. p. 104.

Idem, p. 116.

COSTA, GilcileneDiasda.Curricularte:experimentaçõespós-críticasemeducação.RevistaEducaçãoeRealidade.Porto Alegre: v.36 2011. Disponível em: http://seer.ufrgs.br/educacaoerealidade/article/view/11554. Acesso em 03/12/2014. p. 280.

7 GUATTARI, Félix. As três ecologias. trad. Maria Cristina F. Bittencourt. Campinas: Papirus, 1990. p. 8. 
interrelacional dessas três ecologias que será possível propor uma outra forma de habitar o mundo, haja visto que o regime tecnocrático vigente, apesar de ter se dado conta dos impactos ambientais que temos causado, o faz de uma perspectiva industrialista. Guattari expande a percepção da nocividade dos impactos do nosso modo de habitar o mundo, levando em consideração as inúmeras mutações técnico-científicas oriundas da acelerada revolução tecnológica. Para além do registro ambiental compreendido como meio ambiente, essas modificações que temos causado atuam sob essas três ecologias.

As três ecologias vivem um momento de colapso, dado que o funcionamento operante tem por princípio paradigmas pseudocientíficos - centrados em ciências duras e na ideia de progresso e evolução que influem diretamente sobre a produção de subjetividades plastificadas, massificadas ou então psicologizadas pela chave da psicanálise.

A ecosofia é portanto uma proposição de um outro regime de produção do real que ao invés de operar pelas relações binárias e duras separando sujeito de objeto, trata as três ecologias, vistas como intensidades e processos, opostas termo a termo à ideia de estrutura ou sistema.

A escola pensada como um ecótono se insere no plano da ecosofia social que "consistirá, portanto, em desenvolver práticas específicas que tendam a modificar e a reinventar maneiras de ser no seio do casal, da família, do contexto urbano, do trabalho, etc." ${ }^{8}$ E, será, portanto, comprometida com a reconstrução de um conjunto de modalidades das relações humanas, dos padrões repetidos pela ecologia mental, "longe de buscar um consenso cretinizante e infantilizante, a questão será, no futuro, a de cultivar o dissenso e a produção singular da existência."

Dessa forma, o que interessa ao âmbito escolar é o florescimento das diferenças, o tensionamento das normalizações e a efervescência de planos de pensamentos ético-estéticopolíticos.

Desse ponto de vista, o trabalho desenvolvido pela arte na escola é crucial, pois atua diretamente na produção de subjetividades individuais e coletivas, apresenta um plano de pensamento do afeto capaz de modificar as relações de si com o outro, de si com o diferente, com o ambiente.

A ideia de escola como ecótono pretende produzir uma espécie de plataforma, algo que está sempre no meio, nem início nem fim. ${ }^{10}$ Lugar onde se dão essas relações entre arte e educação, plataforma de intensidades infinitas. Chamamos de ecótono por proximidade com a ecologia, de plataforma por afinidade com a filosofia da diferença, mas poderíamos também falar em istmo, se quisermos falar em termos geográficos. Trata-se de enxergar a escola como uma ligação entre penínsulas.

De um lado, avista-se a educação - vasto continente, cuja fauna e a flora são de uma imensa variedade. Do outro, vê-se uma larga península, rodeada por um arquipélago de multiplicidades,

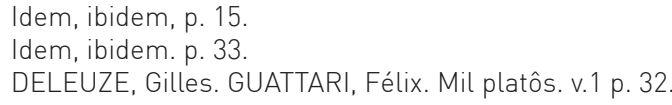


chamado Arte. Entre elas, o istmo. Por "entre" entendemos aquilo que não pertence nem a um nem ao outro, mas que diz respeito aos dois.

O que, portanto, se passa nesse cruzamento que não é nem arte nem educação?

A arte-educação parece ter se ocupado em responder essa pergunta partindo da premissa de que um "hífen" ou uma "barra" fossem capazes de assegurar conjunções. Como dois dados, prontos e delimitados, um lado arte - àquela capaz de elevar o espírito da sociedade, possibilitar a ascensão cultural das minorias, pois "ser culturalmente alfabetizado é 'possuir as informações básicas necessárias para prosperar, florescer, ser bem-sucedido no mundo moderno' e vale para todas as classes sociais (....."11 Do outro lado, uma educação comprometida com a cidadania, autonomia e crítica social, mas que se usa da imitação, do bom e verdadeiro, das respostas prontas, para atingir o seu fim.

A escola como ecótono, por sua vez, não opera sob essa lógica de educação e tampouco espera da arte uma espécie de redenção estético-cultural. Como o ecótono é sempre meio, plataforma, istmo, terceira margem, acontecem as mais inesperadas e rotineiras coisas. Chegam alunos, olham o celular, tomam sol, repetem de ano, passam para a universidade, olham o celular, ralam o joelho, choram de amor, mandam mensagem no celular, puxam cabelo, pulam o muro, tiram selfie no CEPEUSP, copiam tarefas, fotografam a lousa, picham o banheiro, sentam no pátio, com bluetooth passam músicas, copiam lista de exercícios de matemática e assim se passam os duzentos dias letivos nesse ecótono, a parecer que é uma mesmice, é tudo igual.

Ainda que o cotidiano para o senso-comum represente o conforto do reconhecível, segundo Blanchot não se trata de familiaridade, e sim de estranhamento:

O cotidiano escapa. Porque ele escapa? É que ele não tem sujeito. Quando vivo o cotidiano, é o homem qualquer que o vive, e propriamente falando, o homem qualquer não sou eu nem é o outro, ele não é nem um, nem outro, e é ambos em sua presença intercambiável, sua reciprocidade anulada, sem que, por isso, haja aqui um reconhecimento dialético.12

Justamente pelo seu caráter banal o cotidiano é o solo onde florescem as experiências da escola-ecótono, no qual há sempre "relâmpagos, reverberações, cintilações"13 deflagradoras de vitalidades dentro do cotidiano - zona de passagem dos acontecimentos que atravessam a experiência compartilhada entre tantos. Ele, o cotidiano, ainda que atacado por todos os lados em direção à recognição e representação de subjetividades-alunos, professores, formas-disciplinas, tudo ao que se está acostumado a fazer em educação, é um grande aliado contra a mesmice que transforma a escola num grande marasmo para tantos.

Refratário à identificação e homogeneização (ainda que a figura do bedel resista), o cotidiano é feito de uns alunos, alguns rostos, alguns gestos, imperceptíveis, impessoais, onde 
abrem-se fendas para diferenças.

A arte como elemento pulsante do pensamento opera em conjunto com o cotidiano banalizado, com o cotidiano da mesmice de senso-comum a fim de provocar vida ali onde parecia haver nada, trazer desconforto contra a apatia dos corpos cansados, surpresas e inserções poéticas para aqueles que parecem já não ver. Sem que haja necessidade de identificação e autoria, trabalha pelas bordas, florescendo a escola-ecótono, numa espécie de constante ataque poético.

A educação que circula nesse ecótono é também uma educação que escapa a conceitualizações (nada de teoria - um plano organizado, territorializado e hierárquico) e à didáticas (estratificação, um modus operandi da estrutura), se interessa menos por uma pedagogia da forma já pronta (resposta-solução) do que pela pedagogia da pergunta-problema, na qual o pensamento "tem tudo a ver, por outro lado, com aquilo que, em uma zona que não é a da atualização, das coisas já determinadas e já formadas, faz saltar o impensável."14

Assim, o aspecto principal dessa educação, ao contrário das muitas pedagogias, não é o ensino e sim como se aprende, numa via de mão-dupla. Nela o elemento principal é o pensamento, e leia-se pensar não como dar respostas corretas à perguntas estabelecidas, isso é da ordem da representação. Pensar é tarefa de criação, é travar lutas entre sentidos, é busca daquilo que está no seu fora.

A tarefa educacional é da ordem do estranhamento e não da conformação e da identificação. Um rasgo no caos, uma fissura com possibilidade do novo, do intempestivo. Educação que não vai de encontro ao Ideal. Não é, portanto, a Educação normativa das Leis e dos Parâmetros Curriculares, não é a educação da sala de aula do silêncio amedrontado frente ao poder castrador do professor-Mestre.

Não é de verdades e universalidades que se cerca essa educação. É de uma educação menor, menos interessada nas metanarrativas e na ideia de educação como salvação ou fonte de libertação. "Não interessa à educação menor criar modelos, propor caminhos, impor soluções. Não se trata de buscar a complexidade de uma suposta unidade perdida." ${ }^{15}$ Essa educação lê as 'verdades" como ficção-científica, sorri dos ideais da formação humanística.

Uma educação que não quer um mundo melhor, pois não se trata de um outro mundo, ou além do mundo, não se deseja nenhum tipo de metafísica. Não fala em original e cópia. Não trabalha com professor (cópia replicadora do original) que forma alunos (cópias-aprendizes). Pouco se interessa pela essência e origem das coisas, propõe-se, ao invés, testar como elas funcionam, que combinações podem ser feitas, como juntar coisas impensáveis.

O que se espera dessas combinações não são soluções cartesianas ou representacionais de nada, ao contrário, a verificação será feita com Spinoza: se o que se produz possibilita bons ou maus encontros como imanência, se é um encontro alegre há aumento da potência, se não será

14 TADEU, Tomaz. A arte do encontro e da composição: Spinoza + Currículo + Deleuze. Revista Educação e Realidade. v.27. n. 2. Porto Alegre: Jul/dez 2002. Disponível em: http://seer.ufrgs.br/educacaoerealidade/article/view/25915. Acesso em 20/11/2014. p.49.

15 GALLO, Sílvio. Deleuze e a educação. Belo Horizonte: Autêntica, 2008. p. 68. 
um encontro triste, que diminui a potência de fazer a vida vibrar, pois "o que importa é o deviroutro." 16

Uma educação que convida Nietzsche para sentar-se à sua mesa, com quem rapidamente compõe uma pedagogia dionisíaca do dizer-sim à realidade como uma "prática que não se preocupa em emitir juízos de valor, separar arte da produção mundana, apontar o que é divino e o que é demoníaco.(...)." ${ }^{17}$ Pedagogia que brinda a vida e todo seu sentido trágico, na qual a tarefa principal é viver - algo que não se ensina. Um antídoto, um escárnio, um tapa de luva de pelica naqueles que continuam de geração em geração, há séculos, dando as mesmas repostas, fazendo as mesmas perguntas, sem nenhuma dúvida disso, sem nem sequer perceber a pulsão da vida e todos os seus ciclos de transformações.

Por fim, ainda que a concepção de escola como um ecótono seja utópica, de difícil assimilação pela lógica atual (que reproduz um modelo com mais de dois séculos), ainda assim cabe à aula de arte ser esse espaço de experimentação para além dos meios e dos objetos de arte.

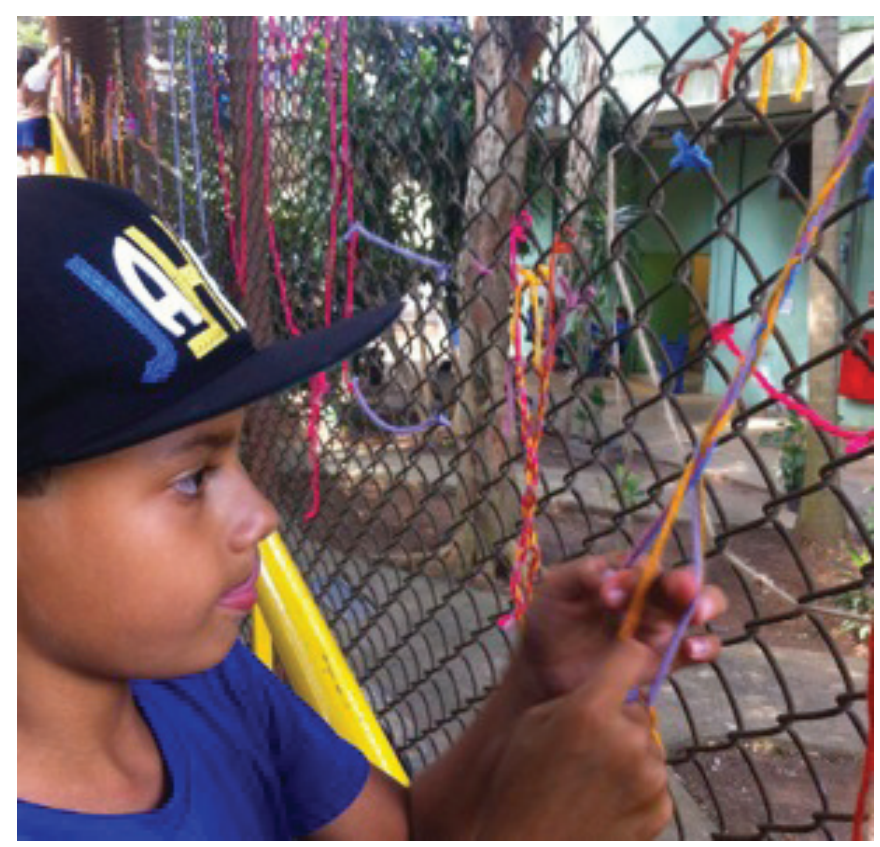

Experiências para além do papel e lápis, Desenhos, 2015.

16 TADEU, Tomaz., op. cit. p. 52.

17 ZORDAN, Paola. Arte com Nietzsche e Deleuze. Revista Educação e Realidade. v.30. Porto Alegre: Jul/dez 2005. Disponível em: http://seer.ufrgs.br/educacaoerealidade/article/view/12472. Acesso em: 20/10/2014. p. 262. 



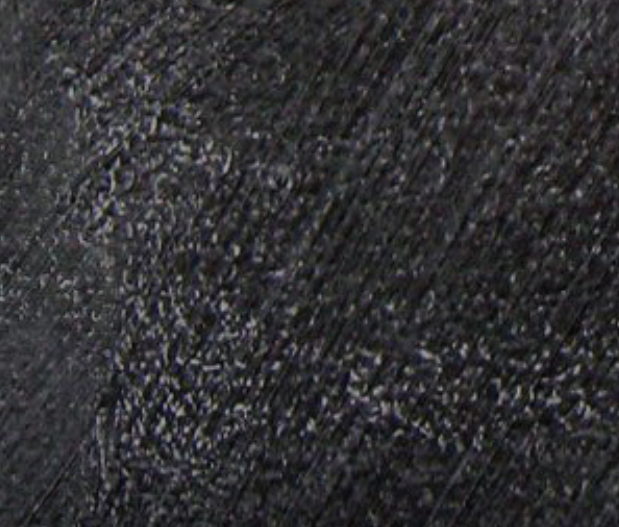




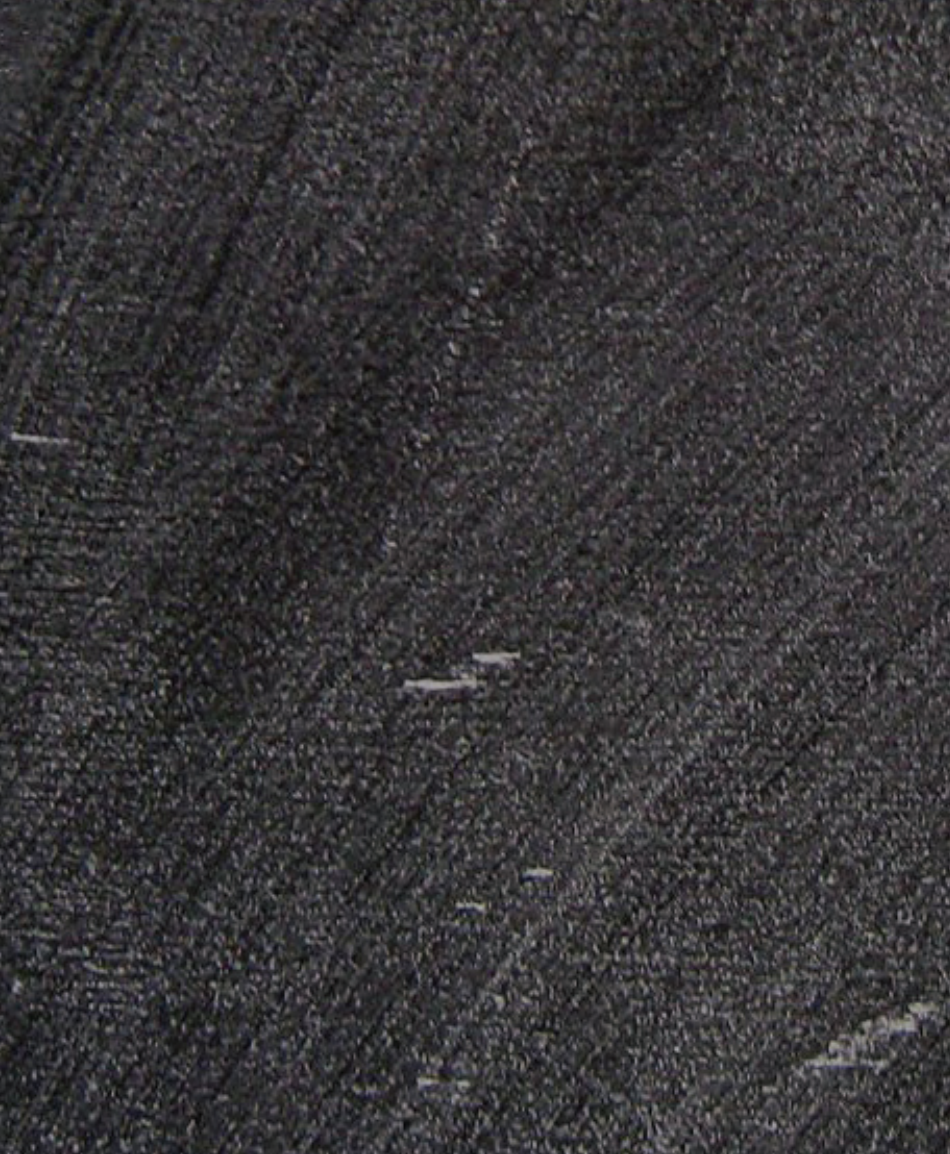

\section{Flu tuações}





\section{Flutuações}

Uma rosa é uma rosa é uma rosa

Gertrude Stein

Esse verso de Gertrude Stein, talvez o seu verso mais famoso, fala da reiteração de uma coisa que insiste em ser-estar em si mesma. Seria o professor "uma rosa"? Pode um professor ser vários ao mesmo tempo em que está sendo professor?

Certo dia, em sala de aula do $4^{\circ}$ ano do Ensino Fundamental, eu relatava um episódio ocorrido com um professor dos meus tempos de criança, quando uma aluna concluiu em voz alta: "É gente, a professora já foi aluna". Achei essa afirmação tão preciosa que passamos um tempo conversando sobre o que eles pensavam ser o professor. Ideias tão fantásticas surgiram, para eles o professor provavelmente fica guardado no armário junto com os livros e só saí quando os alunos chegam.

Flutuação é uma tentativa de pensar quais são os lugares ocupados pelo professor enquanto este está exercendo seu papel. Inicio lançando mão do texto de Roland Barthes, intitulado "Escritores, intelectuais, professores", para explanar sobre os lugares ocupados pelo professor e pensar com ele outras possibilidades de habitar uma escola como ecótono, bem como evidenciar a separação dos saberes tratada no verbete Geologia.

Barthes apresenta com acuidade as disjunções entre a tarefa desses três personagens sociais. Professores e intelectuais se aproximam pelo lugar da fala, enquanto o escritor se diferencia dos dois primeiros por tratar fundamentalmente da escrita. Tanto o professor quanto o intelectual passam por constante análise diante de seu público, pois a fala é a ferramenta deles e não há como apagar uma fala, apenas pode-se retificá-la, mas ainda assim ela deixará seu rastro, pois, segundo o autor, a fala tem cheiro próprio. $O$ intelectual seria aquele que habita os dois lugares, o da fala e o da escrita.

Entre a escrita e a fala: esta pesquisa. Um "entre as margens" que diz respeito ao professor, a sua fala, e à ressignificação da fala pelas palavras - própria do processo de escrita. É algo como uma memória provocada por um cheiro específico, pois se por um lado a fala exala, por outro a escrita não tem cheiro algum; uma vez produzida ela silencia, para depois voar para longe do corpo do escritor.

Entre professor e aluno: o contrato. Ainda que exista um contrato verbal controlado pelo professor - aquele que versa sobre os limites e responsabilidades -, há, sobretudo, um outro contrato velado, que preenche de sentido o trabalho docente.

Esse contrato, no entanto, é de mão dupla e sustenta a relação pedagógica, seja pelo professor que exige ser reconhecido como tal (com as características que the caiba: severo, acolhedor, rígido, etc.), seja pelo aluno que espera a garantia de uma boa formação pelos seguintes itens: 1) acompanhamento a uma boa integração profissional; 2) preenchimento, por parte do professor, dos papéis que lhe são tradicionalmente atribuídos (autoridade cientifica, transmissão de um capital de saber, etc.); 3) aprendizagem sobre os segredos de uma técnica (de 
investigação, de exame, etc.); 4) método (que esse aspecto, sob a bandeira de um santo laico, seja um tipo de iniciador de asceses, um guru) 5) representação de um "movimento de ideias", de uma escola, de uma causa e que seja o seu porta-voz (...)". ${ }^{1}$

Segundo Barthes, tais atributos configuram um posicionamento à figura do professor, que, examinado diante das perguntas "Falo em nome de quê? De uma função? De um saber? De uma experiência? O que eu represento? Uma capacidade científica? Uma instituição? Um serviço?", 2 pode nos ajudar a pensar para além dessa configuração.

Barthes nos responde assertivamente: fala-se sempre em nome de uma linguagem - seja a escrita como representação do seu contrário, seja a fala.

Em relação a esse aspecto, permito-me discordar da classificação feita por Barthes. Não penso que apenas essa pesquisa, ou esse tipo de pesquisa inscrita no mundo acadêmico, possa ser considerada uma produção intelectual. Para o pensador, o intelectual, assim como o professor é aquele que fala, escreve, confere aulas, palestras e, portanto, lida com um outro, já o escritor lida diretamente com o processo de escritura. O que configura o intelectual como um personagem distinto do professor é a pesquisa como lugar de produção e reflexão - o que corrobora uma visão bastante difundida de que professor ensina e o pesquisador da educação reflete sobre o ensino.

Ao contrário dessa segmentação está o professor-pesquisador, inclusive a partir da concepção barthesiana de pesquisador, como aquele que quer perguntar algo, e, sem dúvida, obter uma resposta. Nós, professores, estamos quase que em tempo integral nos perguntando o que e como ensinar, se fazendo uso desses ou de outros materiais, nessa ou naquela disposição espacial, além de lançarmos, a cada aula, uma dezena de perguntas aos nossos alunos, pois "ensinar (fazendo pesquisa) e pesquisar (ensinando) consistem, desta maneira, em criar soluções e, ao mesmo tempo, enigmas". ${ }^{3}$

Assim, lembramos daquela questão elencada por Barthes: falo em nome do quê? o professor-pesquisador, muito além da escrita e da fala, guarda um descontentamento e uma desconfiança diante daquela pedagogia do disciplinamento de saberes e sujeitos, das respostas prontas e do já-feito e esperado, sobretudo, questiona-se

as formas de racionalidade e suas promessas de liberdade, igualdade e fraternidade; duvidam das naturalizações de raça, sexo, geração; estranham o que era familiar e problematizam o que não era problemático; desconstroem sentidos, referentes e privilégios; identificam os dinamismos espaços-temporais do que era tido como determinado e solidamente perpetuado; reconhecem o difícil equilíbrio entre técnicas de coerção e

1 BARTHES, Roland. "Escritores, intelectuais, professores". In: Professores e outros ensaios. Lisboa: Presença, 1975. p. 25-61. p. 30.

$2 \quad$ Idem, ibidem. p. 36.

3 CORAZZA, Sandra Mara. A formação do professor-pesquisador e a criação pedagógica. In: Revista da FUNDARTE. ano.1, v. 1, n.1 (jan.-jun. 2001) - Montenegro : Fundação Municipal de Artes de Montenegro, 2001-. p. 14. 
processos de construção e modificação dos Eus. ${ }^{4}$

Portanto, se o professor é pesquisador, o que ele pesquisa? O que ele tanto quer saber? Ou melhor, parafraseando Gilles Deleuze em sua aula intitulada $O$ ato de criação, ministrada a alunos do curso de cinema, em 1987, "o que nós, professores, estamos realmente fazendo quando estamos sendo professores, ou seja, quando estamos em sala de aula?".

Nesse ponto nos deparamos com a natureza da pesquisa do professor: mais do que propor soluções inovadoras para perguntas já conhecidas - sem desmerecer tal empreitada -, o que fazemos é algo da ordem da criação. Deleuze nos fala que o que une cada atividade criadora é a capacidade de criar espaços-tempos. ${ }^{5}$ Pois é disso que se trata uma aula. Um espaçotempo em que o professor-criador apresenta como atividade fundamental a invenção de novas perguntas, de outras relações com o outro e com o conhecimento.

A respeito do professor, Sandra Corazza diz que:

[...] sua principal contribuição é ser uma sementeira de vivências e sentidos imprevistos, que implode o sistema habitual e consensual da educação. Implosão, que cria condições, tanto para professores quanto alunos, de capturar as forças dos acontecimentos educacionais, em suas modulações assignificantes, vitalidades assubjetivas, realidades ininterpretadas, devires inorgânicos e imperceptíveis. ${ }^{6}$

Com isso, mais um deslocamento é proposto: professor-pesquisador, professor-artista.

Os sinais diacríticos utilizados na junção dessas palavras servem justamente para propor a criação, não de uma palavra composta, mas de um encadeamento vocabular, partindo da ideia de que uma união semântica entre esses termos é perfeitamente possível dada a natureza do trabalho de cada um deles, mas que, configurando-se como um só vocábulo, poderia sugerir uma ideia de conformidade e unidade. Ao contrário disso, o encadeamento sugere movimento, podemos deslocá-los, mudar os termos de lugar, mas a junção se mantém potente: professorpesquisador-artista, artista-professor-pesquisador-intelectual.

Essa reivindicação, por dilatar o espaço do professor ou do artista, não pode ser considerada nova. A propósito de uma exemplificação própria da arte, e nesse caso, da literatura, podemos citar um trecho de uma carta de Flaubert, enviada a George Sand, pseudônimo da escritora e baronesa francesa contemporânea a ele, analisando o papel do crítico literário, que passa de gramático à historiador, se pergunta: "quand sera-t-on artiste, rien qu'artiste, mais bien

$4 \quad$ Idem. ibidem.

5 DELEUZE, Gilles. O ato de criação. Especial para a "Trafic", tradução de José Marcos Macedo, publicado na Folha de S. Paulo de 27/06/1999.p. 5. Disponívelem: http://escolanomade.org/images/stories/biblioteca/downloads/deleuze_ato_de_ criacao.pdf. Acesso em 20/02/2015.

6 CORAZZA, Sandra Mara., op. cit. p. 15. 
artiste? [quando será possível ser artista, nada além de artista, verdadeiramente artista]"7.

Não creio que essa questão esteja subordinada a um desejo de reconhecimento, pois este o escritor já obtinha. A ideia de artista que ele parece anunciar não é a do artista de prestígio social, mas uma legitimação que parte do entendimento de que a natureza artística perpassa, inclusive, outras profissões, como a do tradutor, para citar o exemplo de Flaubert. Nesse sentido também nos fala Deleuze, naquela aula à turma de cinema: há poucas distinções entre arte e ciência, no que diz respeito aos procedimentos do pensamento nessas disciplinas.

Podemos lembrar que não faz mais que quatrocentos anos que a separação entre arte e ciência foi estabelecida, quando "arte" designava toda atividade realizada até o século XVI. "Isto a partir de sua definição platônica, propagada pela cultura greco-romana via autores como Galeano e Ramus, que entendem a arte como todo procedimento humano que serve para produzir certo resultado. Juntamente, também há a concepção aristotélica, que divide esses procedimentos entre aqueles que visam a transcendência, Ars Liberalis, e aqueles que funcionam mecanicamente pala a obtenção de técnicas com fins práticos, ars servilis". ${ }^{8}$

Arte entendida não apenas como um procedimento do pensamento, mas como um modo de fazer. A crítica de Flaubert aos tradutores é perfeitamente possível de ser feita aos professores de arte, que, por vezes, trabalham na chave de historiadores, empenhando-se que os alunos dominem cronologicamente uma história da arte ocidental e branca. Em outros casos, esforçam-se em operar através da lógica da gramática visual, reduzindo a aula de artes visuais aos elementos do ponto, plano, linha, cores quentes e frias.

Podemos nos perguntar: quando, então, serão eles próprios os artistas em sala de aula?

O artista-professor-pesquisador-intelectual Ricardo Basbaum, tendo em vista o hibridismo característico da contemporaneidade, e incomodado com a palavra "artista", que parecia não mais dar conta da multiplicidade que envolve a profissão nos dias de hoje, inventa um novo termo "artistas-etc":

[...] quando o artista questiona a natureza e a função de seu papel como artista, escreveremos "artista-etc" (de modo que poderemos imaginar diversas categorias: artista-curador, artista-escritor, artista-ativista, artistaprodutor, artista-agenciador, artista-teórico, artista-terapeuta, artistaprofessor, artista-químico, etc). ${ }^{9}$

Porém - vale acrescentar -, o artista que só faz ser artista o tempo todo é artista-artista.

7 Carta de FLAUBERTà GeorgeSand, fevereiro de 1869. In: LIMA, Alceu Amoroso. Estudos literários.v. 1. Rio de Janeiro: Companhia Aguilar Editora, 1966. p. 18.

8 ZORDAN,Paola.PercursosdasArtesVisuais:geologiadeumadisciplina.33oEncontrodaAssociaçãodePesquisadores emEducação.Disponívelem:http://33reuniao.anped.org.br/33encontro/app/webroot/files/file/Trabalhos\%20em\%20PDF/GT246006--Int.pdf. Acesso em 04/03/2015.

$9 \quad$ BASBAUM, Ricardo. Eu amo artistas-etc. In: Políticas Institucionais, Práticas Curatoriais,

Rodrigo Moura (Org.), Belo Horizonte, Museu de Arte da Pampulha, 2005. Disponível em: https://rbtxt.files.wordpress. com/2009/09/artista_etc.pdf. Acesso em 20/12/2015. 
Para Basbaum, tanto a palavra "artista" quanto a palavra "arte" são impregnadas, feitas de inúmeras camadas que carregam diferentes significados, mas que acabam sendo reduzidos em um único sentido - hegemônico e consensual. Neste sentido, "artista-etc" é, para Basbaum, uma forma de mexer no léxico habitual que muitas vezes aparece decantado, e de também ampliar este vocabulário.

No entanto, não se trata apenas de operar com as palavras: com "artista-etc", Ricardo Basbaum faz uma inflexão no tipo de posicionamento do artista em relação à vida. Na frase de Flaubert, o que vemos é uma reivindicação de que fosse artística, por exemplo, a tradução, que em certa medida se alinha com o pensamento exposto de que era legítimo se pensar que qualquer atividade até o Renascimento fosse considerada uma arte. $\mathrm{O}$ que Basbaum apresenta é um movimento contrário que parte do artista para a vida, pois é o artista que não quer se ver encerrado em si e em seu rótulo. Esse comportamento e princípio aproximam-se muito do que propõem Allan Kaprow com o seu an-artist, Lygia Clark, com a reestruturação do self, entre outros artistas da geração 1960/70, que requisitavam a efetiva aproximação e imbricamento entre arte e vida.

Entretanto, o caminho não é o mesmo, há um novo deslocamento que parece bastante interessante para se pensar a posição da figura do professor, pois o artista-etc não quer negar a si e se desmanchar na vida, como fazia a geração acima citada. Não se trata de desinstitucionalizar a arte; ao contrário disso, como os artistas-etc não se contentam com as categorias comuns, eles não separam suas pesquisas artísticas de qualquer trabalho que desenvolvem: "não podem evitar a combinação de suas investigações artísticas(...), esta é sua força e singularidade particulares". ${ }^{10}$

Isso posto, pergunta-se: o que faz o artista quando é professor?

Esse artista-professor, incapaz de se separar em figuras distintas, usa da sua pesquisa, propõe situações artísticas, pensa a aula como um acontecimento. Ou, ainda, como dirá Basbaum, a respeito do artista-etc quando se trata de um artista-curador - mas que para nós serve de exemplo contíguo ao trabalho do artista-professor -, o que eles fazem é criar uma rede, montar um conjunto de "atos sensoriais provocativos".11

Neste ponto, remonto ao texto de Barthes, com o qual já fizemos o agrupamento professor-pesquisador-intelectual, para agregar o elemento imprescindível para qualquer professor, não apenas aos professores de arte: o ser artista, de acordo com essa perspectiva apresentada. Portanto, a lição do professor-intelectual-pesquisador-artista (não importa a ordem das designações), seria:

[...] a lição emancipadora do artista, oposta termo a termo da lição embrutecedora do professor, é a de que cada um de nós é artista, na medida em que adota dois procedimentos: não se contentar em ser homem de um ofício, mas pretender fazer de todo o trabalho um meio de expressão; não 
Para finalizar, recorro aos apontamentos finais de Barthes em Escritores, intelectuais, professores, especialmente àquilo que o autor chama de "reunião da fala", - espécie de comunhão entre professor, intelectual e seu público, ou seja, a constituição de um espaço-tempo baseado na relação com o outro. Nesse sentido, temos, em comum, a ocupação de um lugar de encontro com o outro pela fala, ou seja, algo que desfaz a rigidez das categorias que Barthes apresenta e que, aparentemente, em nosso sistema educacional, se mantêm cristalizadas.

No limite, habitar o trânsito entre pesquisador-professor-artista se resumiria a uma busca por um estado de suspensão como forma de relação, cujo objetivo seria, segundo Barthes:

[...] tentar encontrar uma arte de viver, a maior de todas as artes, dizia Brecht(...). Em suma, nos próprios limites do espaço docente, tal como ele é dado, tratar-se-ia de trabalhar para traçar pacientemente uma forma pura, a de flutuação (que é a própria forma do significante); esta flutuação não destruiria nada; contentar-se-ia em desorientar a Lei: as necessidades da promoção, as obrigações da profissão (que nada proíbe desde logo de honrar com escrúpulo), os imperativos do saber, o prestígio do método, a crítica ideológica, tudo está aí, mas que flutue. ${ }^{13}$

Que flutuemos então na escola (tanto melhor se funcionando como ecótono), em deslocamentos afetivos, em atos sensoriais provocativos, com ênfase no trânsito e no hífen do professor: artista - pesquisador - intelectual - performer - aprendiz - potência. "Que tristes são as coisas, consideradas sem ênfase". ${ }^{14}$ 

(2)
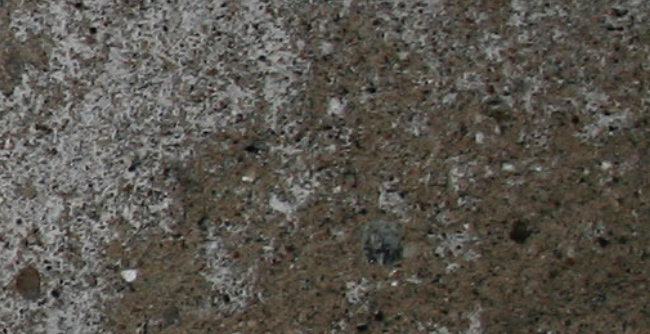

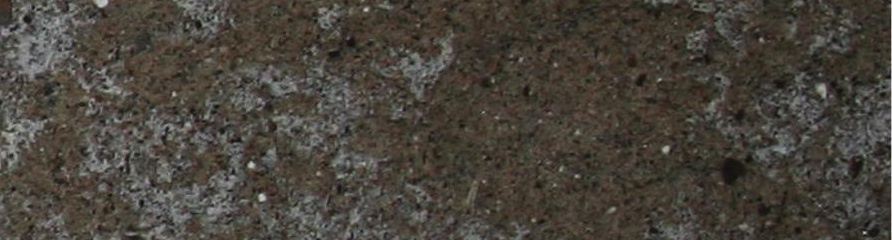

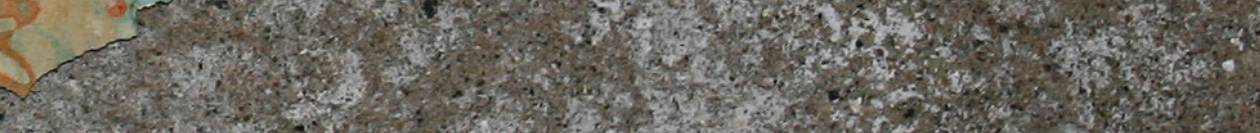

4.1.7.

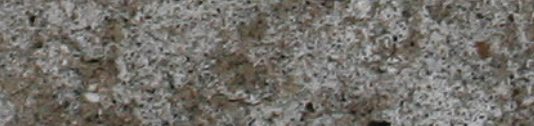

(1)

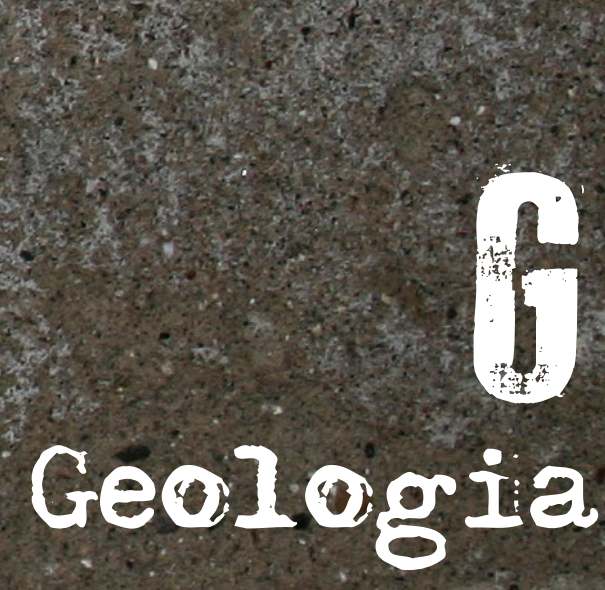




\section{Geologia}

A geologia opera uma problemática mutação com o seu objeto - no caso, a terra. No entanto, a terra é fruto de camadas, sedimentações, estratos, fissuras, curvas de visibilidade, encontros, regimes de enunciação, misturas - não muito diferente do que acontece quando se estuda arte e educação, ou melhor, do que acontece no encontro dessas duas "terras".

Fazendo um paralelo com a geologia, que, para compreender a atualidade de seu objeto precisa remontar e traçar panoramas, cotejar acúmulos, histórias, acontecimentos passados, encontraríamos esse campo que estuda o "entre" a educação e a arte. Pois a educação e a arte também operam sobre uma superfície sedimentada por conceitos, saberes constituídos ao longo do tempo, e que, nesse caso, nesse campo, resvalam na escola. Por esse motivo, para entender, ainda que brevemente, como a arte se inscreve na educação, será preciso retornar a uma possível história de seus sedimentos, numa espécie de geologia da arte na escola.

De partida, vemos uma certa defasagem entre a escola e a atualidade. Jorge Ramos do Ó, em análise sucinta e precisa, nos fala sobre um possível desencontro entre as práticas escolares e o mundo atual:

[...] o modelo secular que temos hoje é um modelo que foi criado no final do século XIX e que se baseia estruturalmente, digamos assim, na construção de grupos homogêneos de alunos que progridem por classes e onde existe sempre uma correlação entre a idade do aluno e o saber que the é fornecido. Estes grupos-classe são, ainda, constituídos por regimes de avaliação muito próximos e o conteúdo ministrado é um conteúdo racionalista. ${ }^{1}$

Não é preciso traçar um panorama rigoroso da história da escola para perceber do que fala Jorge Ramos do Ó; basta ter frequentado alguma escola para entender que poucas mudanças foram feitas desde sua criação até o atual modelo que temos.

Para Julia Varela, podemos encontrar raízes ainda mais antigas para a escola de hoje numa correlação direta com o surgimento e a constituição dos colégios jesuítas do Renascimento, momento em que foi criada, segundo a autora, uma espécie de maquinaria escolar. Deste aparato, surge a criação de um estatuto da infância e disso derivam a necessidade de educálas em um lugar fechado e o controle sobre os saberes a serem ensinados. Para qualificar esses saberes, surge também uma sistematização do ensino, que se torna um modelo para as demais instituições escolares.

É claro que aqui se trata de uma visão bastante rápida e esquemática sobre o tema, que

1 Ó, Jorge Ramos.COSTA, Marisa.Desafiosà EscolaContemporânea:umdiálogo.IN:Educação \& Realidade-ISSN01003143 (impresso) e 2175-6236 (online). Disponível em: http://seer.ufrgs.br/educacaoerealidade/article/view/6653. Acesso em 18/02/2015. 
é muito bem explorado por diversos autores. O que me interessa é pensar, ainda que brevemente, como o disciplinamento dos saberes, ainda hoje tão arraigado e delimitado, sustenta uma suposta hierarquia entre o conhecimento favorecida pela elaboração dos currículos escolares, privilegiando alguns saberes em detrimento de outros, como ocorre no caso da arte como disciplina escolar. Com isso, vemos o impedimento de que misturas entre saberes se efetivem como um princípio de trabalho, o qual sustentaria por princípio a ideia de uma escola como ecótono.

Entender a decantação desses processos nos auxilia, para além de compreender melhor o terreno, a criar uma estratégia de atuação sobre ele de modo a produzir inserções da arte na escola por outros caminhos que não a releguem ao estatuto de "disciplina menor". Mas como esse processo se deu? É sabido - e, mais uma vez não é preciso ser professor para estar ciente disso -, que há uma hierarquia entre os saberes que ali circulam.

Segundo Julia Varela,

[...] os saberes pedagógicos são o resultado, em boa parte, da articulação dos processos que levaram à pedagogização dos conhecimentos e à disciplinarização interna dos saberes. Estas classificações e hierarquias de sujeito e saberes costumam, em geral, ser aceitas como algo dado, como naturais. $^{2}$

Esse procedimento de composição e eleição dos saberes a serem ensinados, da maneira como ainda os vemos hoje, foi constituído, segundo o pensador Michel Foucault, no lluminismo. A despeito das discussões sobre a racionalidade que envolvem a Ilustração, Foucault, seguindo com Varela, vê nesse momento histórico o surgimento de um campo de batalha dos saberes impregnado pelo signo da razão. 0 interesse de Foucault no Iluminismo se dá, sobretudo, para entender, a partir do relevante papel exercido por instituições educacionais - universidades napoleônicas e academias -, como se deu esse movimento, ou melhor, essa luta entre os conhecimentos, que levou à extinção de alguns saberes e ao surgimento de outros, como as ciências humanas.

A busca por tal legitimidade, numa espécie de luta que Foucault chamou de "disciplinamento interno dos saberes", ancora-se na intervenção direta ou indireta do poder político, que envidou esforços para preparar uma reorganização dos saberes, de modo a poder governar os sujeitos a partir de quatro grandes procedimentos.

Essa movimentação dos saberes, segundo Varela, operou em quatro níveis, a saber:

mediante a eliminação e desqualificação do que se poderia denominar pequenos saberes inúteis e irredutíveis, ou economicamente muito custosos. Em segundo lugar, mediante a normalização desses saberes. [...]

2 VARELA, Julia. O estatuto do saber pedagógico. In: SILVA, Tomaz T. (org.) O sujeito da educação: estudos foucaultianos. Petrópolis: RJ: Vozes, 2008. p. 93 
Em terceiro lugar, mediante sua classificação hierárquica, que permitiu de algum modo que se ordenassem, desde os mais particulares e materiais (que a partir de então serão os saberes subordinados), até os mais gerais e formais (que serão as formas mais desenvolvidas e norteadoras). Em último lugar, mediante sua centralização piramidal que permitiu o seu controle, que assegurou as seleções e possibilitou a transmissão. ${ }^{3}$

Ou seja, os saberes foram sendo arranjados em níveis e graus crescentes de dificuldades. Os saberes manuais, pelos procedimentos acima descritos, que sugeririam uma relação de cooperação entre mestre e aprendiz, foram desqualificados e denotados como saberes menores, em detrimento dos saberes que ganhavam legitimidade científica.

Levando em consideração tais procedimentos para a organização dos saberes à qual, ainda no século $X X I$, continuamos vinculados, fica mais evidente que pelo alto custo, particularidade e pouca legitimidade científica, a arte não figurou entre os mais elevados conhecimentos na pirâmide do currículo. E, aparentemente, por esse motivo que parte da literatura específica da arte-educação parece, ainda hoje, operar com a finalidade de convencer e institucionalizar a importância da arte na educação. Em vários dos textos da área, é possível encontrar afirmações como "arte é cognição, é profissão, é uma forma diferente da palavra para interpretar o mundo, a realidade, o imaginário, e é conteúdo" ou, então, "Arte não é enfeite".4

No entanto, ainda dentro dos pressupostos iluministas, encontra-se a crença na arte como componente indispensável para a educação estética. Há um consenso na função formativa da arte, baseada nos princípios de uma educação como Bildung, alinhada à crítica de todos os valores sacralizados. A cultura estética, para Schiller, seria "aquilo que deve conduzir a natureza humana à plenitude de seu desenvolvimento, à conjunção de suas forças sensíveis e racionais, enfim, à união de dignidade moral e felicidade". ${ }^{5}$

A partir dessa frase de Schiller, é possível aventar que a justificativa para a permanência do ensino da arte na educação se dá como uma espécie de complementação às demandas científicas que figurariam no currículo escolar àquela época e que continuam a ser conduzidos da mesma maneira na atualidade, a ver pela "ênfase que a concepção de educação da atual Lei de Diretrizes e Bases coloca sobre a tecnociência, como princípio e requisito básico no saber, na sociedade e na cultura, é contrabalançada pelo «conhecimento da arte», compreendido como conhecimento «sensível-cognitivo, voltado para um fazer e apreciar artísticos e estéticos e para uma reflexão sobre a história e contextos na sociedade humana»" . 6 O que vemos nos Parâmetros como uma espécie de enaltecimento do que se denomina "estética da sensibilidade", é uma forma de mascarar os efeitos do excesso de racionalidade instrumental, marca dos Parâmetros Curriculares Nacionais para as demais disciplinas.

Idem, ibidem. p.90

BARBOSA, Ana Mae. A imagem no ensino da arte. Anos oitenta e novos tempos. São Paulo: Perspectiva, 2009. p. 4. SCHILLER, F.apud.FAVARETTO,Celso.Artecontemporâneaeeducação. RevistaIBEROAMERICANADEEDUCACIÓN.N.o 53 (2010), pp. 225-235. p. 227.

6 FAVARETTO, Celso., op. cit. p. 7 
A ideia de educação como Bildung (auto-formação, cultivo), também articulada nessa mesma passagem histórica, particularmente presente na literatura, na filosofia e na pedagogia alemãs,

representa o corolário do projeto de autonomização do sujeito cognoscente e moral, por meio do qual a modernidade filosófica se institui e se afirma, e que, no âmbito das análises e discussões sobre formação, cultivo e educação, forja-se um espaço em que se aprofundam as perspectivas da modernidade. ${ }^{7}$

Segundo José Fernandes Weber, podemos, num rápido panorama, localizar a emergência desse conceito no final do século XVIII e início do XIX, quando a Alemanha, em comparação à França da Revolução e à Inglaterra industrial, ainda era considerada bastante atrasada e agrária. Após a derrota da Prússia pelo exercito napoleônico, uma sensação de destruição e desconsolo assolava os alemães, mas foi gradualmente sendo substituída pela crença na educação como cultivo e formação, bastante marcada, mais uma vez, pela construção das instituiç̧ões superiores de caráter científico, como a Universidade de Berlim (1810).

Bildung é, entretanto, uma noção bastante plural, que figura em inúmeras passagens literárias e filosóficas do século XIX; sua tradução para o português melhor se ajustaria à ideia de "formação". No entanto, formação é um termo bastante vago e amplo, e mesmo dentro da discussão alemã daquele momento surge a necessidade de qualificar essa noção de formação, feita por pesquisadores, filósofos e escritores do século XIX. Disso deriva a ideia de aprofundamento, de transformação, sugerindo uma nova acepção ao Bildung, que passa também a ser entendido como "cultivo".

Mas o que essa concepção alemã do século XVII nos diz respeito? Ora, muito, pois é em parte dessa concepção que a formação do homem deva estar concentrada em espaços institucionais, como escolas e universidades, e, sobretudo, ela

diz respeito a qualquer ser humano, a qualquer cultura que pense o sentido a partir do seu estar no mundo. Particularmente, há um problema contemporâneo, que pode ser pensado com algum proveito a partir daquela tradição, qual seja, o problema da delimitação de áreas responsáveis por pensar a formação do homem. ${ }^{8}$

Agora, de volta aos Parâmetros Curriculares Nacionais, é possível localizar, em torno do potencial educativo da arte, algumas das crenças muito condizentes com a própria noção de Bildung: 1) fonte do potencial expressivo humano; 2) linguagem primeira do homem, e, portanto, de comunicabilidade universal; 3) noção do funcionamento da arte como ruptura e progresso

7 WEBER, José F. Bildung e Educação. Educação \& realidade 31.2 (2006). Disponível em: http://seer.ufrgs.br/ educacaoerealidade/article/view/6848. Acesso em 08/03/2015. p.3.

$8 \quad$ Idem, p. 13 
(espécie de função tautológica); 4) concepção de arte como imagem; e, por fim, 5) a ideia do gênio e da criatividade imbuída à arte.

Segundo Anne Cauquelin, inclusive o próprio conceito de arte que circula na atualidade vem sendo constituído como herança dessas teorias do século XVIII (de Kant, Hegel ao Romantismo), que, em composição com teorias da arte moderna, ${ }^{9}$ têm sido bastante solicitadas nos textos de arte-educação e vão perpetuando e sedimentando discursos que falam em nome da arte, especialmente na área da educação. A partir dessas teorias, firma-se a crença no caráter formativo da arte, legitimando sua presença e "necessidade" na educação desde cedo.

No contexto brasileiro, é possível traçar uma linha histórica de constituição da disciplina "arte" bem condizente com o que foi apresentado sobre o surgimento de disciplinas e saberes durante o lluminismo.

Assim, há uma possível justificativa que indica que parte do que se escreve em relação à arte na educação como uma forma de legitimá-la e reconhecer sua função pode ser encontrada na instabilidade que rondou a disciplina ao longo dos dois últimos séculos. Pois, é sabido que as políticas públicas brasileiras cunharam, nos séculos XIX e XX, na disciplina Arte na educação básica, alguns estigmas advindos do questionamento da pertinência da Arte na escola, por vezes desqualificando-a e reduzindo-a a atividade eletiva ou polivalente, fazendo com que a disciplina, por uma espécie de fragilidade pedagógica, ocupasse um lugar menos privilegiado nas importâncias das matrizes curriculares.

E, por mais que esse quadro tenha se modificado e que hoje não restem dúvidas sobre a importância da arte na educação, a tomar como exemplo o texto introdutório dos Parâmetros Curriculares Nacionais de Arte - "a educação em arte propicia o desenvolvimento do pensamento artístico, que caracteriza um modo particular de dar sentido às experiências das pessoas: por meio dele, o aluno amplia a sensibilidade, a percepção, a reflexão e a imaginação," ${ }^{10}$ vemos que continua-se somando esforços para a legitimação de um espaço mais consistente para Arte como uma disciplina.

Para o reconhecido pesquisador da área, Brent Wilson:

[...] embora a arte-educação seja apenas uma pequena parte do mundo da arte - e aos olhos de muitos uma parte insignificante - ela é, apesar disso, formada e modelada pelo mundo da arte e reflete as suas crenças. A arte-educação tem muitos valores em comum com o mundo da arte, os professores de arte reproduzem as mesmas concepções de realidade que são encontradas também no mundo da arte. ${ }^{11}$

Nessa afirmação, podemos perceber sua investida em atrelar a aula de arte ao mundo

9 CAUQUELIN, Anne. Arte contemporânea: uma introdução. p. 18.

10 Brasil. Secretaria de Educação Fundamental. Parâmetros curriculares nacionais : arte / Secretaria de Educação Fundamental. - Brasília : MEC/SEF, 1997. p. 15.

11 WILSON, Brent. apud MENEZES, Marina. A arte contemporânea como conteúdo e fundamento para a prática do ensino de artes. Dissertação (Mestrado em Arte). Rio de Janeiro: Universidade Estadual do Rio de Janeiro, 2007. p.21 
da arte, como se este fosse donatário de maior importância que o primeiro, mas que, uma vez identificado com aquele, pudesse compartilhar dessa mesma importância.

Chama a atenção a convicção que o autor traz ao apresentar a arte-educação como uma espécie de espelho do mundo da arte. Se isso fosse correto, não estaríamos todos trabalhando a partir de perspectivas abordadas pelos trabalhos de arte contemporânea?

Ao contrário disso, a área parece se desenvolver à margem das discussões artísticas, assumindo uma posição de autonomia em relação à arte, de modo que

\begin{abstract}
as teorias e práticas educacionais em nome da arte, de acordo ou não com os marcos apresentados, [mudanças no estatuto da arte nos séc. XVI e XVII e pós 1960] parecem agora se desenvolver sem necessariamente tomar as práticas artísticas como seu objeto, sistema de referência ou atualidade. $[\ldots] .^{12}$
\end{abstract}

O que significaria dizer que a arte-educação se pretende epistemologia da arte, sem, contudo, a ela se referenciar, mas firmando-se, ao contrário, na concepção de arte como cognição e conhecimento.

Essa concepção aparece também em contraposição à noção de arte trazida pela escola tradicional, de cunho moral e tecnicista, instrumentalizadora do progresso ou da capacidade de representar a realidade por meio de cópia, e, por outro lado, pela concepção que a Escola Nova trouxe consigo: arte como criatividade. Esta concepção serve, inclusive, como uma resposta ao excesso de tecnicismo da primeira.

Herbert Read assumiu um papel de destaque no debate pedagógico brasileiro no final da década de 1940 e influenciou de forma crucial o surgimento do Movimento Escolinhas de Arte do Brasil. Sua concepção de arte baseia-se numa visão psicológica da educação bastante influenciada pelas ideias de Carl Jung, nas quais a liberdade criadora da criança é a fonte de integração social, partindo do indivíduo para o entendimento de sua função no coletivo, pois

visto como um ser criativo, o aluno recebe todas as estimulações possíveis para expressar-se artisticamente. Esse "aprender fazendo" o capacitaria a atuar cooperativamente na sociedade. ${ }^{13}$

Assim, com as Escolinhas de Arte e a difusão de um método que se foca totalmente na expressão individual do aluno, além das consequências de um fazer na aula de arte despretensioso e fruto de eventuais virtuoses, parece fomentar a crença de que o ensino da arte possa dar conta de uma experiência de arte como criatividade - que fora do laissez-faire trazido com as Escolinhas de Arte ainda é bastante marcante nos discursos da arte-educação.

12 HONORATO, Cayo. A formação do Artista: conjunções e disjunções entre arte e educação. Tese (Doutorado em Educação). Faculdade de Educação: Úniversidade de São Paulo, 2011. p. 52. Grifo nosso.

13 FERRAZ, M. FUSARI, M.; FERRAZ, M. M. Arte na Educação Escolar. p 40. 
Apesar de o ensino da arte ter sido caracterizado por diversas configurações, a Proposta Triangular é, sobretudo, a metodologia mais difundida dentre as práticas de ensino de arte até os dias de hoje. Inclusive, sem ser assim denominada, é a base estrutural dos Parâmetros Curriculares Nacionais para o Ensino Fundamental, e, por conseguinte, ali entra em conformidade com seu discurso na direção cientificizante.

Evidentemente, a Proposta Triangular surge como uma investida contra teorias dominantes referidas por Ana Mae. E, sobretudo, face ao risco que o ensino de arte enfrentava com a eminência de deixar de ser oferecido na educação básica, naquele momento ainda como uma atividade e posteriormente à consolidação da Arte-educação é que houve o reconhecimento da arte como disciplina obrigatória na educação básica.

Decerto, somos todos herdeiros dessa luta; no entanto, é importante refletir sob quais bases se sustentaram a argumentação que se encontra na enunciação dessa proposta - arte como conhecimento e cognição.

Porém, ao invés de analisar as consequências para o ensino da arte de cada um dos três pilares dessa proposta - operação que certamente requer bastante atenção - pretendo entendêla em sua totalidade, refletindo sobre a metanarrativa afirmada por tal proposição. E, talvez, seja esse o ponto com o qual nos mantemos mais imbricados enquanto professores de arte.

Em primeiro lugar, podemos verificar que, através da mudança de nomenclatura, que, claramente, tenta deixar de ser vista como uma metodologia para servir como uma abordagem, pois, afinal, "metodologia é construção de cada professor", ${ }^{14}$ na prática não é isso que ocorre. Provavelmente, pelo seu caráter aberto "desenvolvido pelo professor", a proposta tem, ao invés de seu trunfo inclusivo, a capacidade de tudo abarcar e é justamente disso que deriva sua aplicação genérica que supostamente serve a todos os casos. Porém, ao invés de relativismo metodológico, o que se revela é o caráter restritivo de tal proposta:

[...] como se a proposta pudesse prescindir do contexto que pretende compreender, na medida em que, com as "devidas apropriações", isto é, com as devidas correspondências aos modos de agir que prescreve, ela pode ser utilizada em qualquer lugar, com qualquer arte e com qualquer público ${ }^{15}$

Podemos, desta forma, inferir que ao afirmar a arte como conhecimento, a arte-educação parece não enxergar a arte como um sistema complexo com funcionamento próprio, especialmente quando se trata da arte contemporânea, cujas regras e limites estão constantemente sendo mudados e reinventados. Desse modo, acaba-se por deflagrar um descompasso aparentemente irremediável entre o que propõe a arte-educação e a arte.

A Proposta Triangular concentra em si as categorias de algo que se pretende científico, já que "examina aquilo que está exposto diante de si, fazendo corresponder uma experiência a um 
conceito dado geralmente de antemão, um objeto a uma proposição". ${ }^{16}$ Porém, como é possível, no caso da arte, e, se preferirmos, da arte contemporânea, operar a partir de estruturas fixas que colocam limites naquilo que a obra coloca em jogo?

Certamente, ao se pensar como conhecimento, o dispositivo criado pela arte-educação parece reconfortar muito bem expectativas, por um lado em prol de sua legitimação e equiparação com outras categorias científicas, e, por outro, fornecendo substratos para uma prática docente em arte que prescinda da invenção, própria da arte. Ao vincular a arte ao conhecimento, assegura-se que ela é ensinável, e, portanto, necessita de um rol de conteúdos a serem trabalhados. Todavia, o que essa afirmação demonstra de fato é a categorização de um determinado conceito de arte.

Mas esse é apenas um dos aspectos que contribui para a ideia de arte como conhecimento obrigatório na formação humana. O outro vem, certamente, da própria concepção já mencionada de formação como Bildung que "constitui a última elaboração literária, pedagógica e filosoficamente nobre do que hoje chamamos de educação". ${ }^{17}$ Dessa forma, podemos perceber que tanto a arte-educação como a educação praticadas retroalimentam uma noção de arte que apequena sua potência em prol de uma estruturação conceitual dessa experiência. Ambas, juntas ou separadas, não têm dado conta de tratar da experiência contemporânea que nada tem de transcendental, universal e unitária, como queria o projeto iluminista.

De que maneira isso foi feito? Atrelando-a a metodologias e afirmações sobre a importância da arte não apenas nas escola ${ }^{18}$ mas também na vida. Mas o que nos importa aqui é problematizar de que tipo de arte a arte-educação está falando, ou, ainda, o que significa dizer que a arte "representa o melhor trabalho do ser humano"?19

Não consigo acreditar que o trabalho de arte esteja categorizado como o melhor possível a ser feito. Basta se tomar como exemplo artistas como Andrea Fraser, Hans Haacke e Daniel Buren, que situam seus trabalhos no horizonte da crítica institucional voltada ao complexo sistema da arte e suas relações com os campos da política e economia. Contudo, esses não seriam exemplares isolados, pois, de maneira geral, as inúmeras práticas artísticas contemporâneas tendem a embaraçar as noções de belo e de produto artístico. Mais uma vez, pode-se perceber que, ao invés de se endereçar ao sistema de arte, ao qual supostamente a arte-educação se remeteria - inclusive como epistemologia daquele -, vemos uma discussão que, como já foi apresentado, encara a arte como uma categoria universal, e, nesse sentido, uma metodologia que fornece suas regras faz todo o sentido de ser.

Talvez esteja nesse ponto a sua maior fragilidade, pois como pretende, mais recentemente, servir como um modelo multidimensional, ${ }^{20}$ a proposta parece ter a intenção de dialogar com a produção artística atual; no entanto, ela não se atualiza em relação à ideia de leitura de obra, e a

Idem, ibidem. p. 89

LARROSA, Jorge. Nietzsche e a educação. Belo Horizonte: Autêntica, 2009. p. 43.

18 Segundo Ana Mae Barbosa, “a Arte-educação é epistemologia da arte, e, portanto, é a investigação dos tempos. p. 5 .

19 Idem, p. 4.

20 RIZZI, Maria Christina. apud HONORATO, Cayo. A formação do artistaop. cit. p. 87 
obra, consequentemente, é vista como imagem. Para tanto, para que a construção desse discurso de legitimação da arte-educação se legitimasse no campo da educação, condensando arte como imagem, e acrescentando, portanto, conteúdos tidos como elementares da arte, foi preciso a

valorização do ensino de conteúdos básicos de arte necessários à formação do cidadão, considerando, ao longo dos ciclos de escolaridade, os conteúdos gerais do ensino fundamental em Arte são, [por exemplo]: a arte como expressão e comunicação dos indivíduos. ${ }^{21}$

Entretanto, não seria plausível que, uma vez vista como um sistema complexo, contextualizado e sem definições fixas, a arte pudesse fornecer suas próprias regras e conteúdos?

21 BRASIL. Secretaria de Educação Fundamental. Parâmetros curriculares nacionais : arte / Secretaria de Educação Fundamental. - Brasília : MEC/SEF, 1997. PCN - Arte, p. 37. 
Cove $=2$

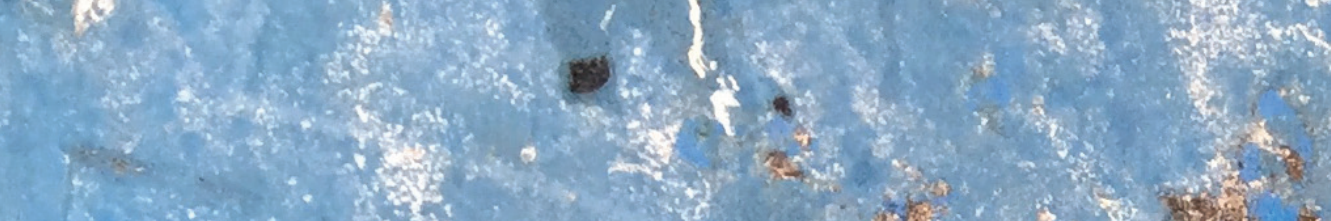

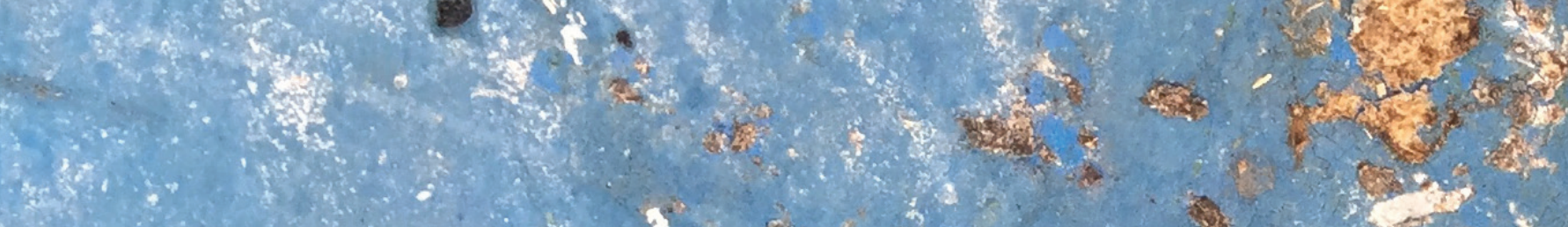
(1)

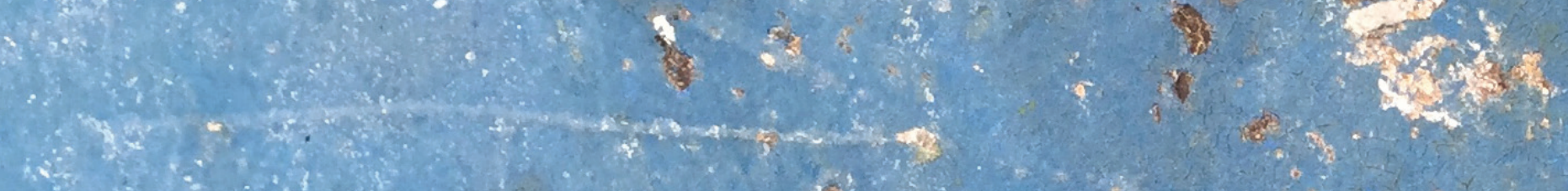

$x^{2}=-2=0$

3

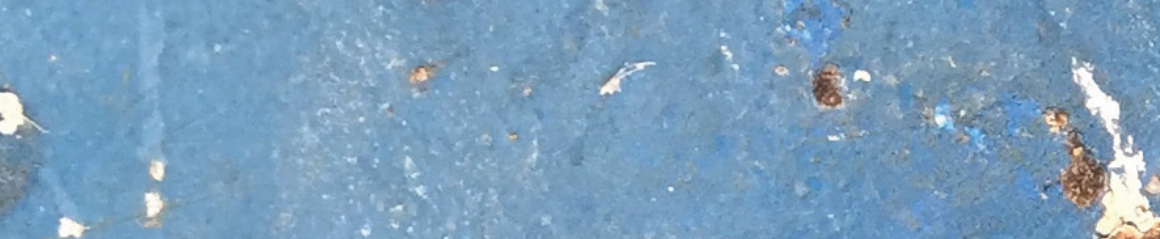

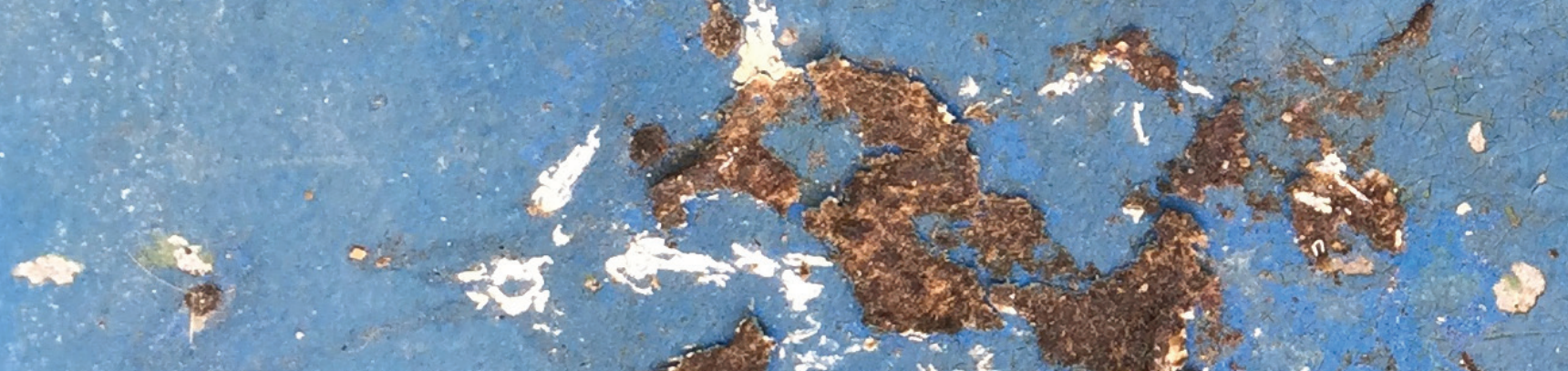
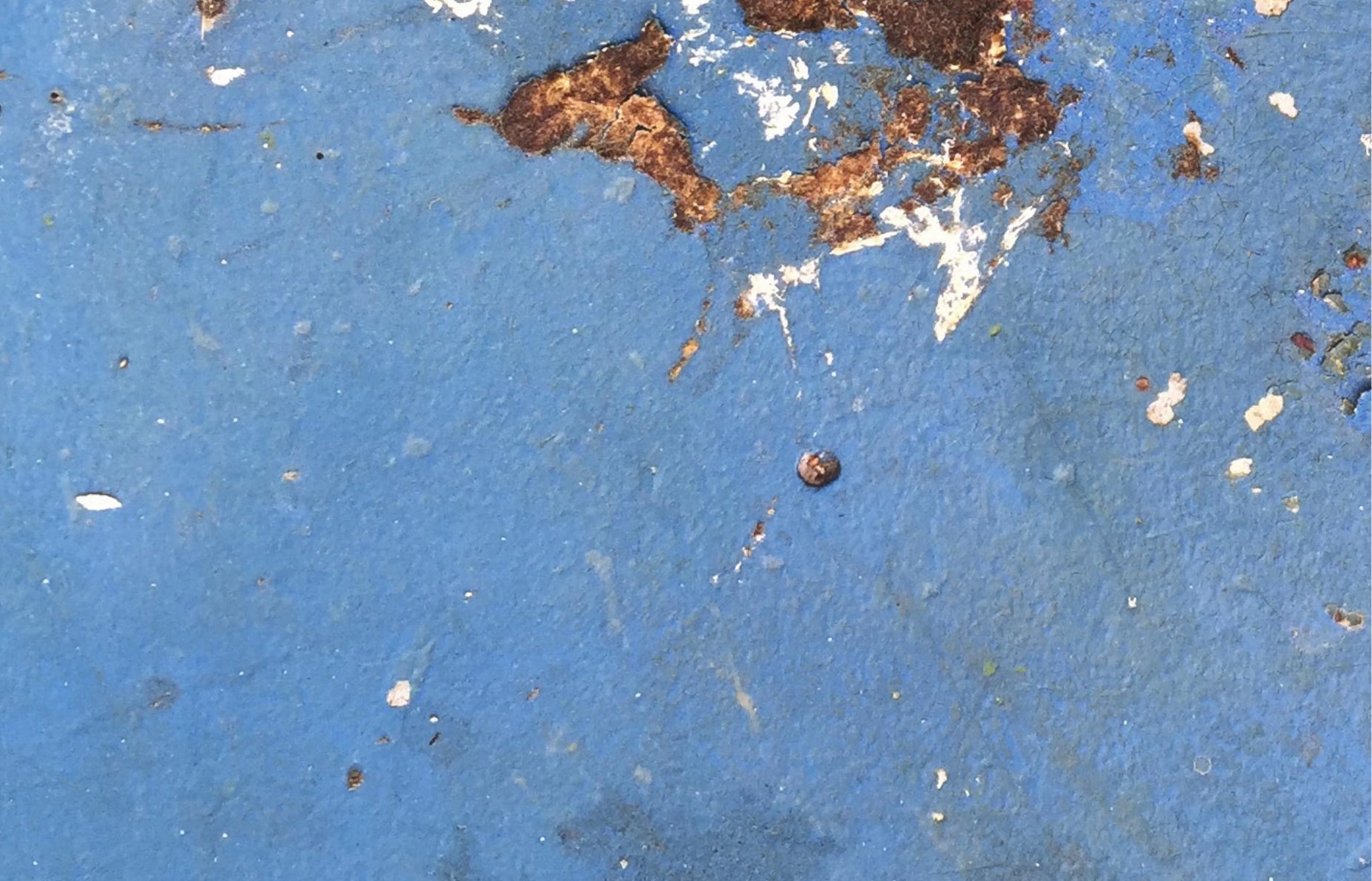

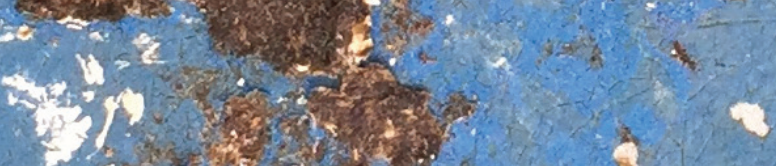

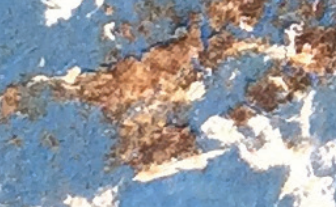
$\frac{x}{x}-5$

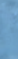


$x+98$

$x_{x \rightarrow \infty}<-$

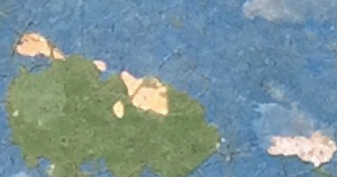

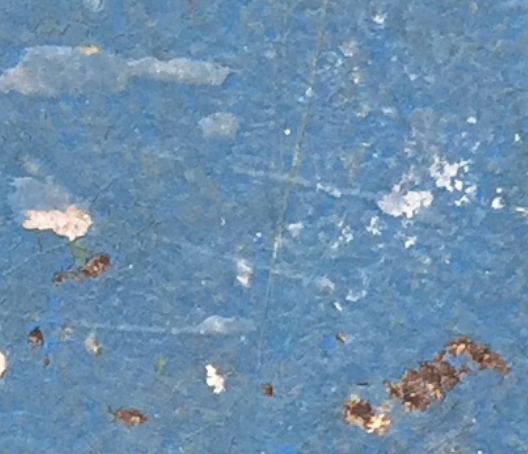

6)

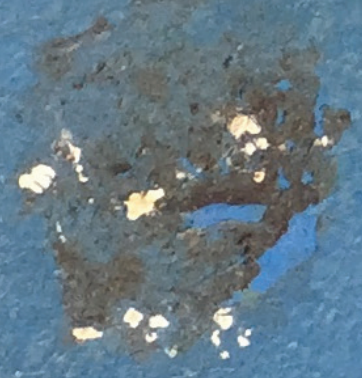

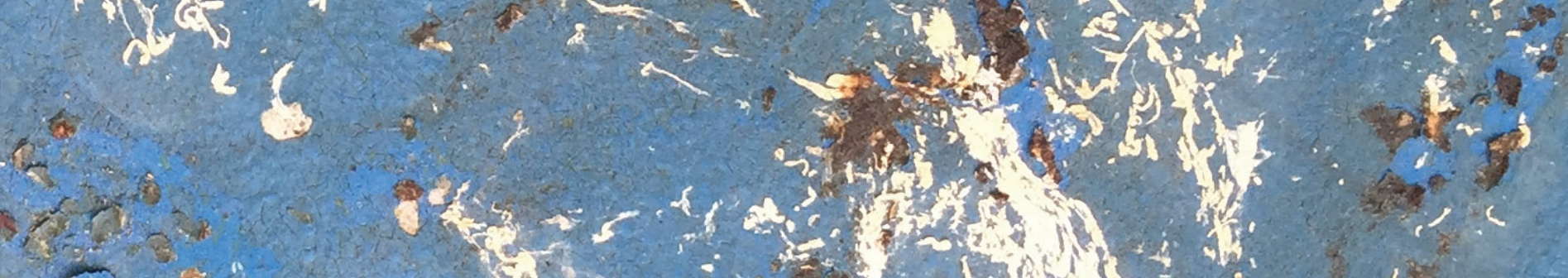

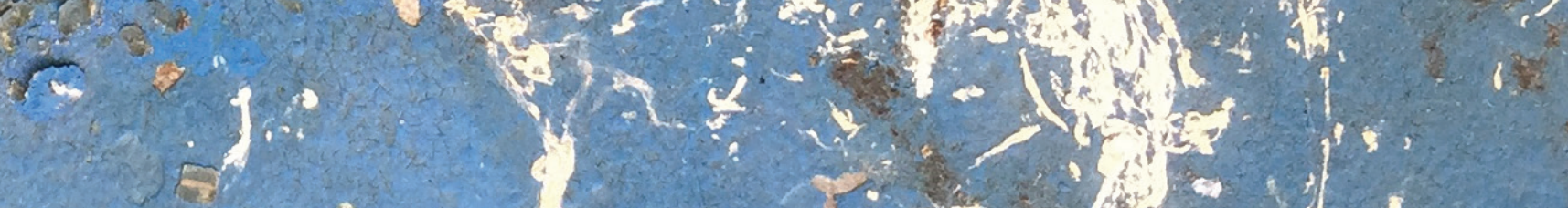

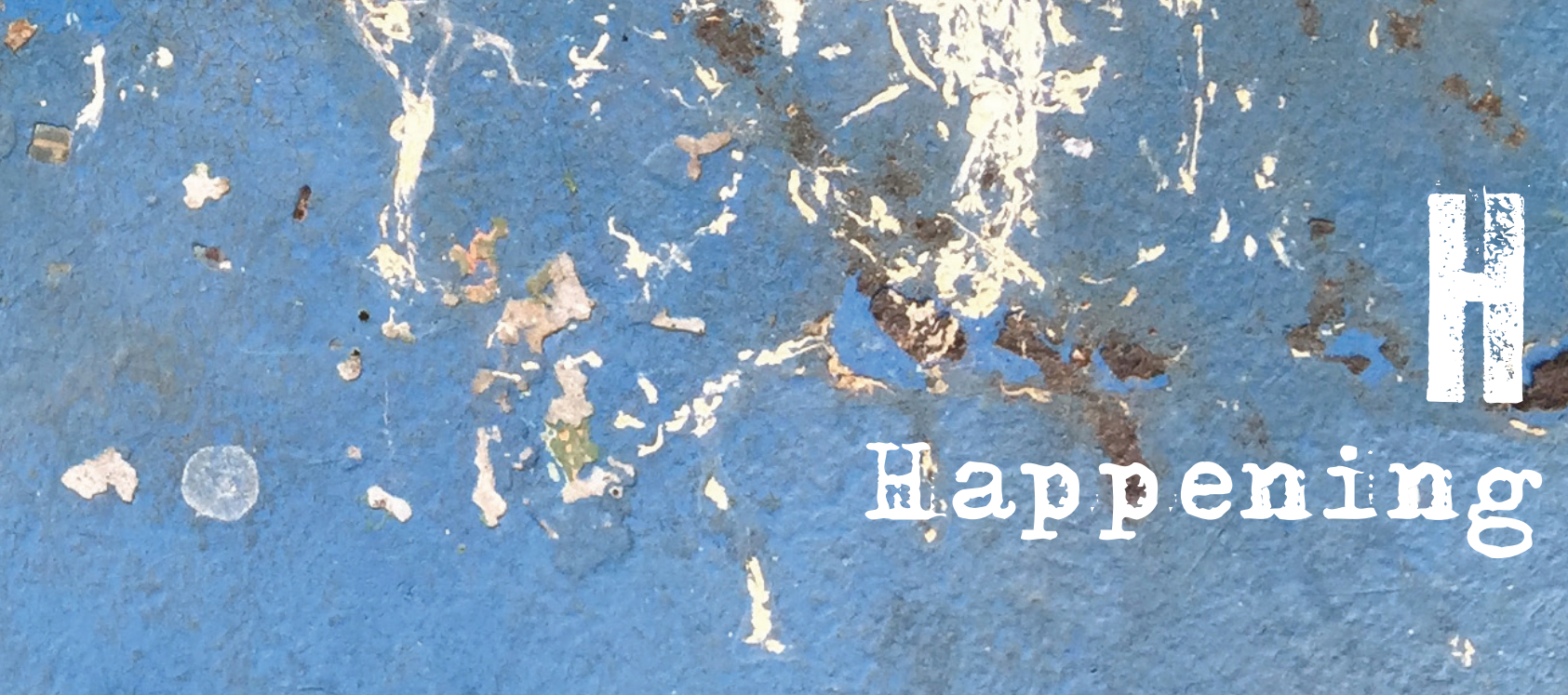



Após dois anos da morte do expoente do expressionismo abstrato Jackson Pollock (19121956), o artista Allan Kaprow escreve uma carta na qual, junto ao seu pesar pela perda, apresenta um novo rumo para a arte pós-Pollock. Através da pergunta: "Não era perfeitamente claro que a arte moderna em geral estava definhando?". ${ }^{1}$ Kaprow, que havia abandonado a pintura, associa a morte de Pollock com a morte da arte moderna.

Allan Kaprow conclui que, após a radicalidade imposta por Pollock, "temos de passar a nos preocupar com o espaço e os objetos da nossa vida cotidiana, e até mesmo a ficar fascinados por eles, sejam nossos corpos, roupas e quartos".2 Ou seja, tratava-se da continuação daquilo que Pollock ensinou à sua geração - uma ação que transbordou os limites pictóricos, saiu para a rua e invadiu a vida.

Allan Kaprow, além de notório artista, foi um grande teórico da arte e produziu textos cruciais para o entendimento das manifestações artísticas das décadas de 1960 e 1970. Com os happenings, Kaprow, para além da idiossincrasia que o termo nomeou para manifestações dessa natureza na arte, propôs uma nova postura tanto do artista quanto do espectador.

Em 1959, Kaprow fez o trabalho intitulado "18 happenings in 6 parts", que consistia na apresentação de 18 ações apresentadas por ele e seis amigos em três salas da Reuben Gallery de Nova lorque. Havia consignas ao público que, no programa da apresentação, eram colocados como parte do elenco. Era possível transitar entre as três salas ao toque de uma sirene e, se o público quisesse aplaudir, só poderia fazê-lo ao final da apresentação (e não entre as ações). Foi essa experiência que cunhou o termo happening que, segundo Kaprow, significa "um jogo, uma aventura, um número de atividades acordadas entre os participantes por e pelo jogo". 3

Nos "18 happenings in 6 parts", Kaprow havia decidido "aumentar a 'responsabilidade' do observador", ${ }^{4}$ convocando uma presença mais ativa do público. Nos convites feitos para esse trabalho, Kaprow imprimiu: "Você se tornará parte dos happenings; irá vivenciálos simultaneamente". Dessa forma, com Kaprow, o termo "espectador" dá lugar à ideia de "participante", pois este se transforma em agente do trabalho, e passa a participar da obra.

Os happenings contestavam as convenções artísticas, mesclando artes plásticas, teatro, música e radicalizando em todas essas linguagens. Como diz Kaprow, com os happenings, foram dadas aos espectadores "oportunidades, tais como: mover coisas, apertar botões.(...) [e isso] sugeriu a necessidade de dar mais responsabilidade ao espectador (...) até chegar ao happening". ${ }^{5}$

Assim, a aproximação entre arte e vida em Kaprow se dava em duplo sentido: primeiro da arte para a vida-tornar os participantes dos happenings conscientes (presentes) em seu cotidiano, por mais trivial que este fosse. E pela entrada da vida na arte - pela desinstitucionalização da

KAPROW.Allan.In:FERREIRA, Glória.eCOTRIM,Cecília.Escritosdeartistas60/70. Riode Janeiro: JorgeZahar, 2009, p.38. Idem, ibidem, p. 44

KAPROW, Allan. “Performing Life”. Revista ARS, vol 8 , n. 15, São Paulo, 2010, p. 1

Idem, ibidem.

Idem, idibem. 
arte e sua restrição ao métier especializado. Assim, dando continuidade a essa pesquisa, Kaprow passou dos happenings, já incorporados pela crítica como uma nova modalidade artística, às Activities, obras que não mais tinham o intuito de serem assistidas, pois se tratavam de roteiros que poderiam ser seguidos por qualquer pessoa em qualquer lugar.

Nos happenings, a ideia de participação do público visava uma reflexão a partir do que era assistido/participado. Já com as Activities, Kaprow buscava a reflexão em ato, a partir do exercício da percepção corporal de cada proposta.

Kaprow, em seu percurso, buscou colocar a arte dentro do estatuto da vida, fora e além do seu establishment, e foi se distanciando paulatinamente do lugares convencionais da arte.

Na década de 1970, Kaprow escreve a trilogia The Education of the Un-artist, 6 partes I, II e III (1971, 1972 e 1974, respectivamente). Nesses textos, Kaprow nos apresenta "senhas" sobre a arte: non-art, un-art, art-art e pos-art. Trata-se de meios de endereçamento da arte em sua relação com a vida e que culminaram no conceito de lifelike art $^{7}$ - um modo de fazer arte como a vida, embaraçando e destituindo as fronteiras entre os termos em uma tomada de posição crítica perante a vida. As ações são realizadas dentro da vida, de acordo com um caráter ético e político: "O an-artista não faz arte real, mas o que chamo de arte como-a-vida [lifelike art], arte que nos faz principalmente nos lembrar das nossas vidas".

Ao adentrar no universo proposto pelo artista, lendo inúmeros de seus textos, deparei-me com uma necessidade de experimentar tensionar também os limites da arte na escola a partir da pergunta: "De que forma, na sala de aula de arte, essas práticas poderiam ressoar para além de um conteúdo a ser ensinado?". Além da pesquisa empírica cotidiana, encontrei um Kaprow dedicado a pensar sobre a educação, particularmente na segunda parte da educação do an-artista, Kaprow vê na escola um lugar potencial de transformações, dado que é sobretudo um espaço de transmissão de valores. Ele se questiona por quê não subverter tais valores, confrontando-os com outros?

Naquele artigo, Kaprow faz uma crítica à sociedade americana, especialmente em relação à noção de trabalho incutida nas relações em geral, como um lugar austero e sisudo.

Em contraposição a isso, Kaprow propõe que os an-artistas façam uma leitura da ideia de imitação e jogo, baseada no livro Homos Ludens, de Huizinga ${ }^{9}$ - bastante conhecido no meio educacional -, para que, tendo suas ações diluídas no cotidiano, façam dele algo distante da seriedade e austeridade impregnadas na ideia de trabalho. Ele propõe, na contramão disso, que o trabalho seja mais parecido com o brincar "com gosto, humor, alegria; é para jogar-brincar". ${ }^{10}$ Kaprow usa propositalmente o verbo to play, que, em português, significa "jogar-brincar", visto que a ideia tanto de imitação quanto de jogo-brincadeira são tidas como contrárias à sisudez do

\footnotetext{
$6 \quad$ Asduasprimeiras partes dotexto foram traduzidose publicados pela Revista Concinnitas: arte, cultura e pensamento eencontram-sedisponíveisem $<$ http://pt.scribd.com/doc/148862145/kaprow-a-educacao-do-nao-artista-parte-l-pdf $\rightarrow$.Acesso em 20/07/2014

KAPROW, Allan. Essays on the Blurring of Art and Life. Berkeley, CA: University of California Press, 1993, p. 201. KAPROW,Allan. “AeducaçãodoUn-artista”, RevistaConcinnitas,ano5,n.6,julhode2014. Disponívelem $<$ http://issuu.

com/websicons4u/docs/revista6/169 $\rightarrow$. Acesso em 03/05/2015.
HUIZINGA, Johans. Homoludens:ojogocomoelementodacultura.trad. JoãoPauloMonteiro.SãoPaulo:Perspectiva,2014. 10 KAPROW, Allan., op. cit.
} 
trabalho, ou seja, algo sem substância, trivial.

Kaprow critica a lógica do trabalho incutida nas mais diversas relações, incluindo a crescente indústria do lazer e do entretenimento e também o modo como essa lógica se reproduz na escola. Para o artista, é no sistema educacional que podemos rever e propor outros modos de vida. Porém, o que vemos é a reprodução dessa lógica massacrante também instaurada nos discursos pedagógicos e bem sintetizada pela máxima: "Trabalhe duro que você chegará longe".

Para Kaprow, a questão educativa talvez seja a principal solução para apresentar novas possibilidades de jogar-brincar na vida, e, para isso, a educação precisa de an-artistas.

Já em um outro artigo, chamado "Sucessos e fracasso quando a arte muda", Allan Kaprow descreve uma aproximação mais efetiva entre arte e educação através do relato de uma experiência em colaboração com escolas de Bekerley. ${ }^{11}$

Kaprow, como parte do seu projeto lifelike art, encampou no início da década de 1960 um projeto chamado Outros Caminhos junto com o educador Hebert Kohl, cuja principal intenção era dar um lugar central às artes no currículo da escola pública. O projeto aconteceu em uma espécie de loja localizada perto de uma escola pública, mas que recebia passantes e outras escolas, desde poucos alunos até professores e turmas inteiras.

O foco do trabalho estava no básico "leitura, escrita e matemática", pois acreditavam que a arte favorecia a aprendizagem desses e de outros assuntos. O projeto durou cerca de dois anos e era avesso aos discursos pedagogizantes em torno da arte. Nesse artigo, Kaprow faz uma cuidadosa avaliação dessa empreitada, tentando deslocar a questão do sucesso ou fracasso dessa ação para uma reflexão acerca do potencial da arte produzida na década de 1960: "o 'Projeto Outros Caminhos' tinha, porém, a intenção de fundir arte com outras coisas não consideradas arte, sobretudo o aprendizado em leitura, redação, matemática, e assim por diante. Significativamente os inovadores movimentos artísticos daquele momento forneceram os modelos para nossos objetivos". ${ }^{12}$ Dessa forma, como saber se aquele projeto havia sido bemsucedido, seria uma pergunta análoga ao questionamento se aquilo que estava sendo feito era ou não arte. Haveria sido uma boa experiência artística? Ou, ainda, haveria sido um genuíno experimento educativo?

Dentre as conclusões possíveis do projeto, Kaprow propõe que a formação dos professores, em geral, seja revisada, pois ele percebeu que os resultados do projeto, além de elogiados e surpreendentes para as comunidades escolares envolvidas, pareciam apenas possíveis dada a liberdade de ação que o projeto tinha por estar localizado na esfera da arte. Kaprow e Kohl tiveram, portanto, o aval para propor e modificar o processo de acordo com o que percebiam funcionar melhor, o que não parecia, segundo Kaprow, acontecer na rigidez da estrutura escolar.

No entanto, o ponto principal que essa experiência aponta não parece recair sobre o

11 KAPROW, Allan. "Sucessos e fracassos quando a arte muda". Arte \&

Ensaios, Rio de Janeiro, v. 18, julho de 2009. Disponível em: http://www.ppgav.eba.ufrj.br/wp-content/uploads/2012/01/ae18_ allan_kaprow.pdf. Acesso em 02/05/2015.

12 Idem, ibidem. p. 151. 
sucesso ou não dessa experiência educativa, mas sim em seu endereçamento. Era arte? Era educação? A ambiguidade de sua identidade era ao que se propunha o artista, para quem seus trabalhos deveriam sempre se manter nessa espécie de limbo indefinido: "Podem a arte experimental e a educação experimental andar juntas mais substancialmente para o bem comum?". ${ }^{13}$

Para Kaprow, essa questão não pôde ser respondida a partir do projeto Outros Caminhos. Com uma visão cética, Kaprow fala sobre a distância do artista em relação à escola - sempre muito ocupado com o mundo da arte, como também da educação em relação à arte. Essa ideia é calcada no preconceito de que a arte é uma liberdade desinteressada em contraposição ao trabalho duro e diário que a educação implica. No entanto, Kaprow aponta para um futuro possível, destacando que, para os artistas experimentais - an-artistas -, o desafio estará em explorar as banalidades da vida, tornando-as mais belas.

\section{Mover coisas, apertar botões}

Impregnada pelos escritos de Allan Kaprow, e tentando responder à sua questão sobre a parceria entre arte e educação como experimentos da vida, propus-me a criar experiências baseada na ideia de Kaprow de que a arte pode fornecer modelos para os meus objetivos em aula de arte.

O que seria, portanto, pensar a aula através da chave do happening? Como aumentar a responsabilidade dos meus alunos no espaço da aula? Logo, uma aula como happening pressupõe novas disposições dos materiais, das mesas e cadeiras, as consígnias e a interação como elemento que transforma a intenção inicial.

Se hoje, no contexto da produção atual, o aumento da participação do público é absolutamente banal, o mesmo não pode ser dito daquilo que se pratica na escola. Ainda que por excelência a disciplina "Arte" advenha de operações e ações práticas de cada aluno implicado em seu trabalho, não se pode afirmar que esse seja um pressuposto de aula. Penso nos três alunos novos de Ensino Médio que, ao entrarem em minhas aulas, trouxeram-me seus cadernos de arte, que nada mais eram do que uma espécie de enciclopédia de termos de arte - movimentos, técnicas, artistas, sem nenhuma prática. Também é sabido que, diante da falta de recursos para trabalhar, muitos professores optam por cursos de história da arte para seus alunos.

Entretanto, foi pensando na oportunidade de aumentar a responsabilidade dos meus alunos que comecei a observar onde elas estavam na aula, isto é, além, é claro, das propostas que são sempre de cunho autoral. Interessei-me em pensar de que forma a presença (corporal) dos meus alunos poderiam ser melhor exploradas.

No $2^{\circ}$ ano de escolarização, assim que comecei a trabalhar com essa faixa etária, percebi que as crianças já dominavam muito bem códigos corporais aprendidos da cultura escolar, seja pelas filas divididas por gênero, seja na disposição espacial das mesmas na sala de aula, como 
também pela disposição dos materiais, usualmente colocados sobre suas mesas de trabalho, de forma que elas nem mesmo precisassem levantar de suas mesas.

Assim, as filas usadas nos deslocamentos sempre determinadas por meninos e meninas escolhidos por serem os mais silenciosos transformaram-se em filas feitas a partir de estátuas e caretas, uma estratégia lúdica para que seus corpos pudessem se reanimar e marcar presentes. Claro que a isso soma-se um pequeno caos momentâneo, que tiraria outros professores do prumo, mas, para mim, era uma questão de presença. Presença que também convoco nos deslocamentos com os alunos (da sala de aula deles para o atelier de artes), ou seja, momentos de temido descontrole, para os quais inventamos narrativas fantásticas, caminhadas na Lua, "pezinho de algodão? ou "pé-de-chumbo", para tentar desautomatizá-los do condicionamento ao qual eles vêm sendo incitados.

O mesmo se dá com a distribuição espacial da sala: sempre que posso, mudo radicalmente as mesas de lugar; o efeito de surpresa e estranhamento provocados pela mudança é imediato. Há sempre algumas disposições que favorecem mais o caos do que outras, o que não passa de uma questão de movimento.

Creio que a mais importante fala de Kaprow diz respeito à aproximação entre arte e vida, pois penso que essa questão deveria ser pano de fundo da prática docente em sala de aula. De minha parte, tenho tentado mantê-la próxima, afinal, por que desvitalizar a arte enquanto se ensina? Por que apartá-la da sala de aula?

Com Kaprow, é possível entender a aula de arte como uma experiência, um acontecimento. E trabalhar o acontecimento requer aquilo que Kaprow nos fala: "estar atento" é equilibrar-se como um acrobata que se orienta ora pelo gesto proposto, ora pela recepção e devolutiva do aluno, pois o acrobata "requer operações que se movimentem: dos corpos e estados de coisas aos acontecimentos; das misturas às linhas puras; da superfície corporal à metafísica do pensamento puro". ${ }^{14}$ Enfim, essa presença escapa à noção de arte como conteúdo e às demais configurações da arte que circulam na educação, pois se relaciona com aquilo que, parafraseando Lyotard, é o "impresentificável".

Finalmente, o que interessa a nós, professores, a partir de Kaprow, é pensar em construir aulas como uma obra de arte, não meramente num sentido mercadológico, hoje imperativo, pois não se trata de reivindicar um lugar no sistema da arte, mas de potencializar a ação, as forças e trazer o corpo para a experiência, atentos aos gestos, transformando "o corpo em um território de ressonâncias destituído de todo o autismo."15

A intenção é a de que tanto professor quanto aluno possam, nessa relação, dentro do universo da sala de arte, operar por lógicas que ultrapassem a representação, idealização e exibição, em uma direção assertiva e de resistência, assim como o corpo em Kaprow, atrás da construção de um novo lugar, do qual o professor siga propositor e participante.

14 CORAZZA, Sandra M. “Pesquisar o currículo como acontecimento em V exemplos”. Disponível em: http://27reuniao.anped.org.br/gt12/t1211.pdf. Acesso em 13/07/2014, p. 3.

15 SANT'ANNA, Denise B. Corpos de passagem: ensaios sobre a subjetividade contemporânea. São Paulo: Estação Liberdade, 2001, p. 99 


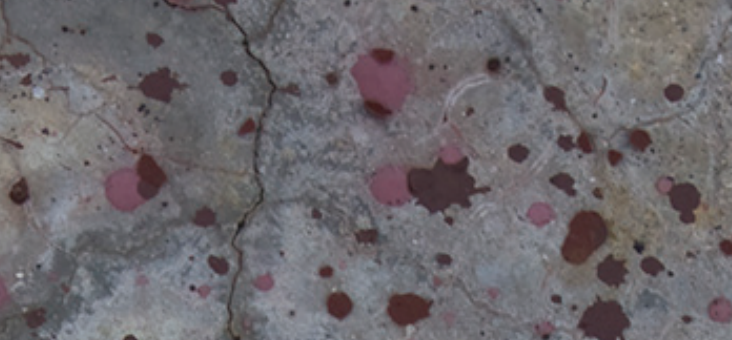

$\because \because$

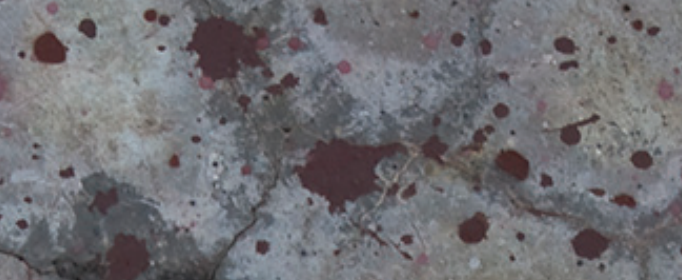

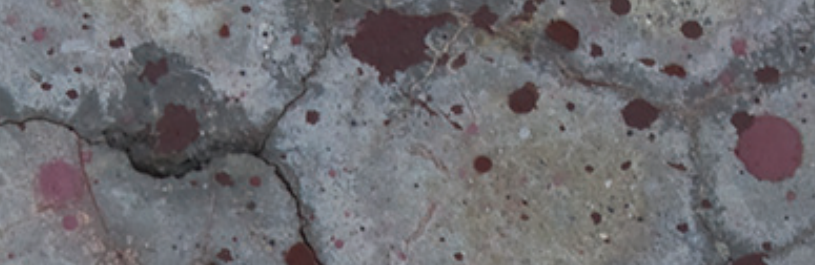

\section{$2 x^{2}=\mathrm{l}^{2}$}

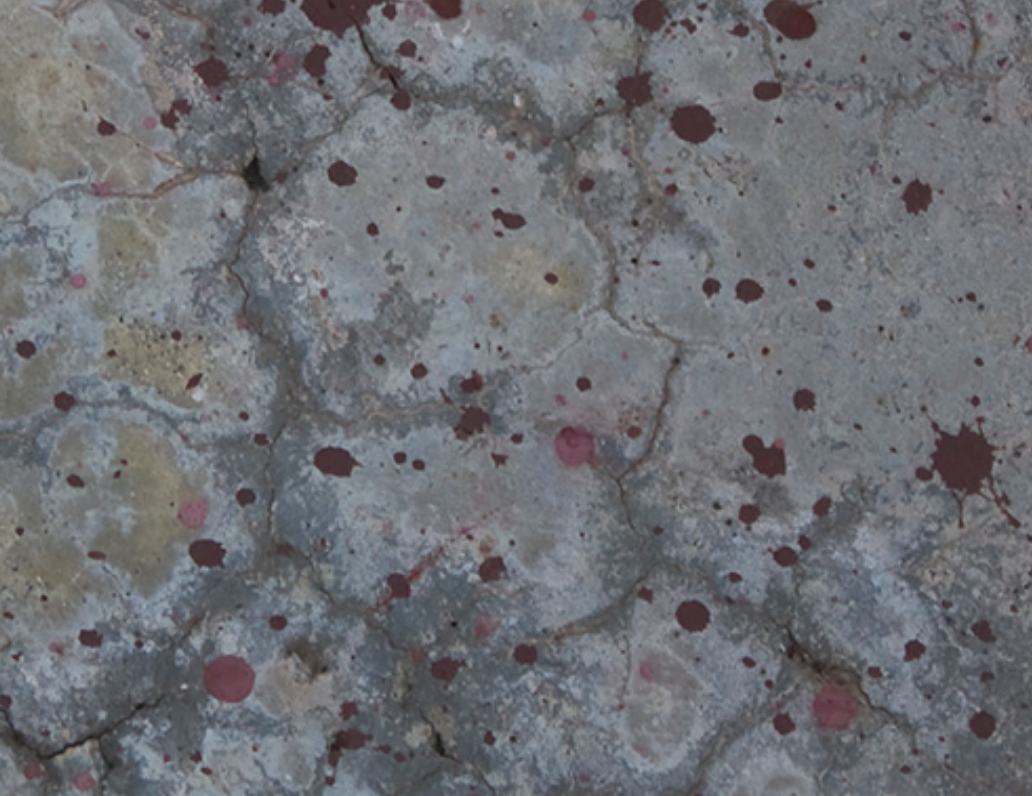

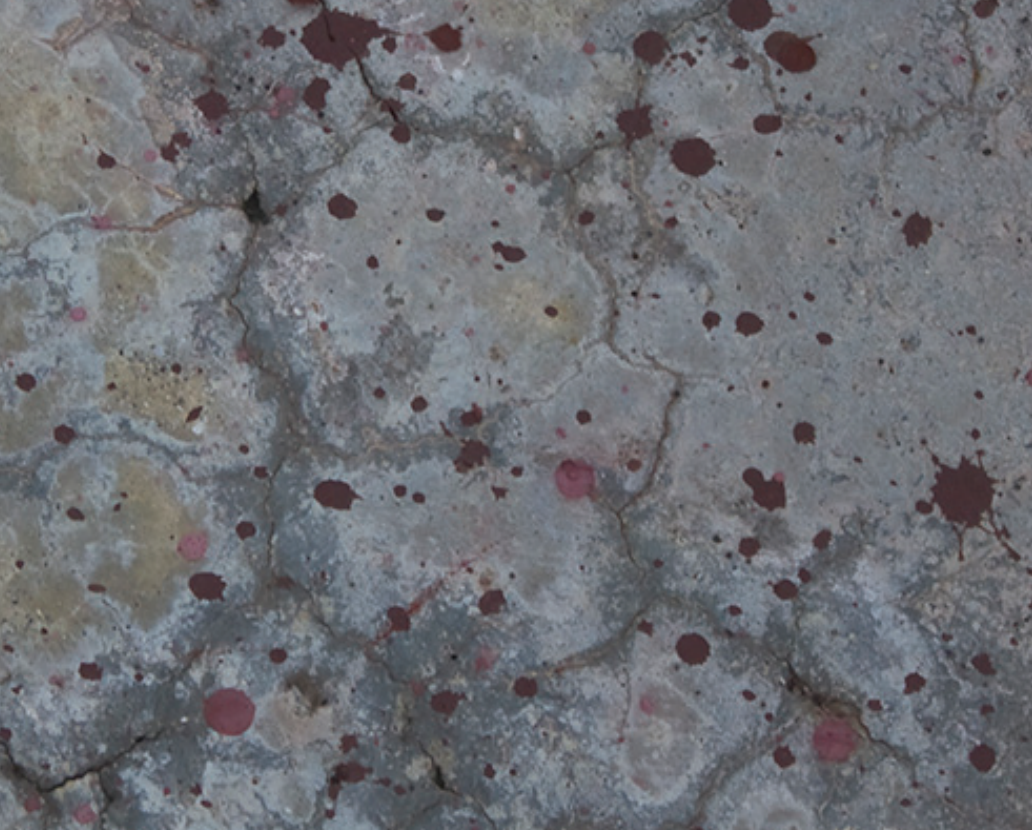

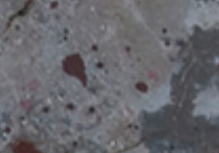

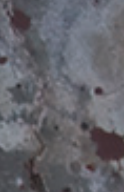

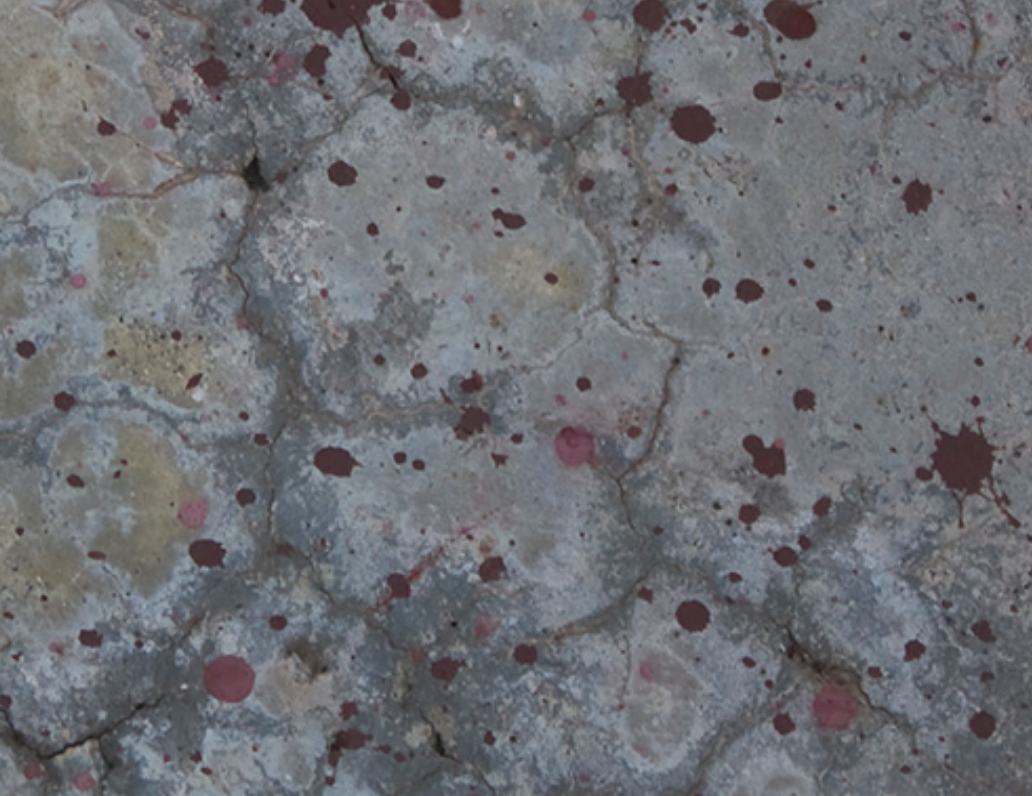

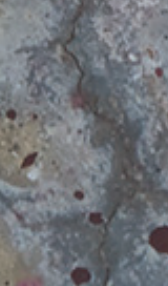

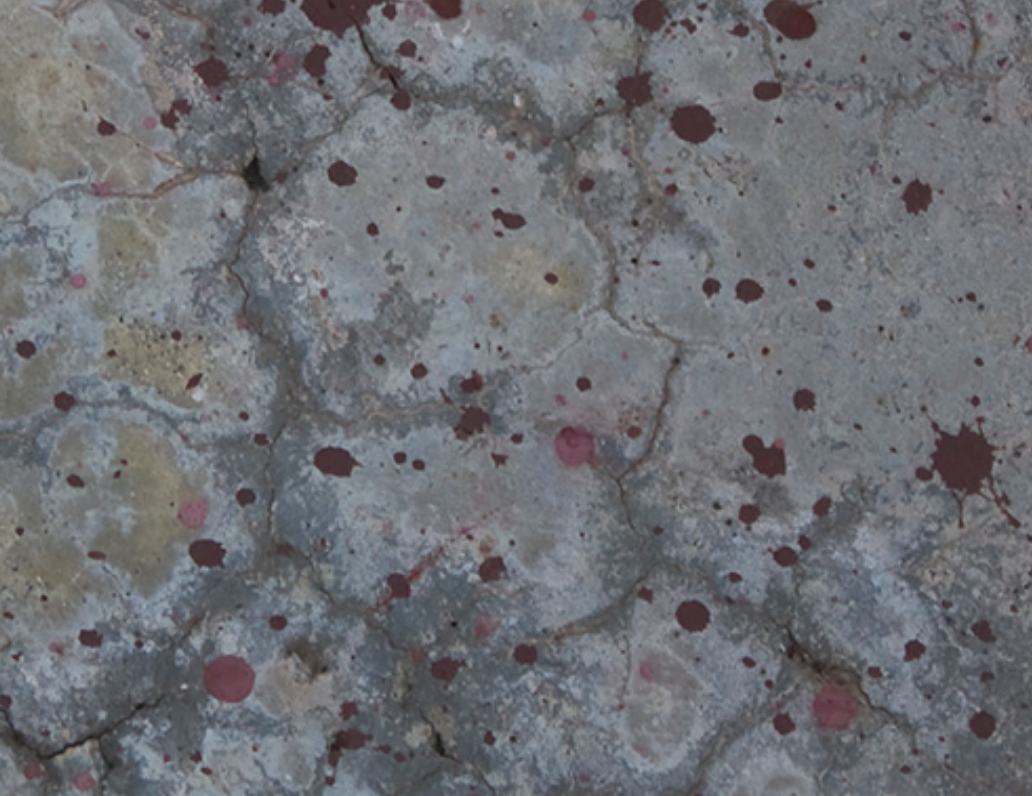
$\frac{1}{-1}$

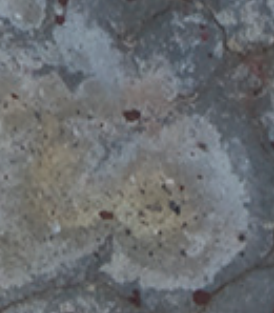

- 2 .

$\therefore ?$
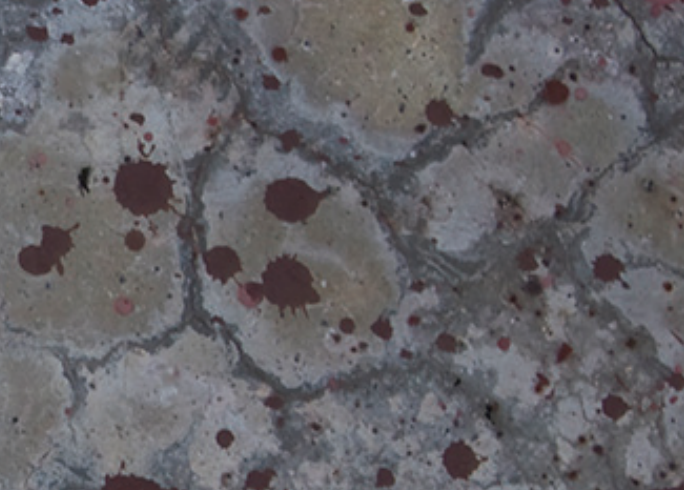

$x_{3}$
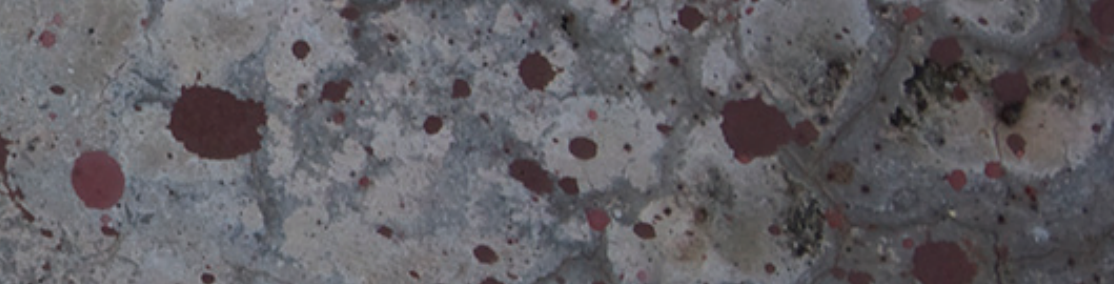

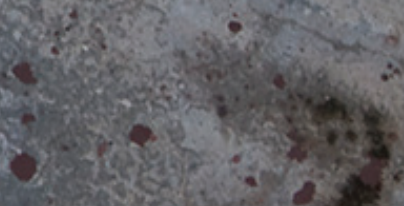

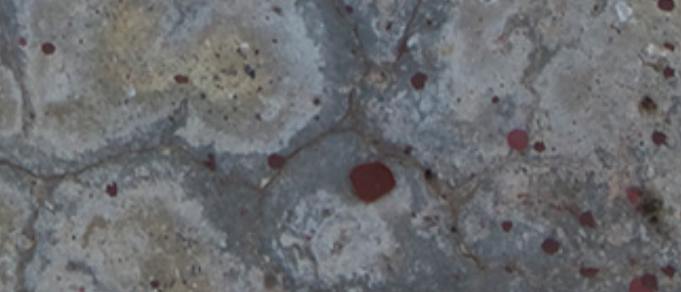

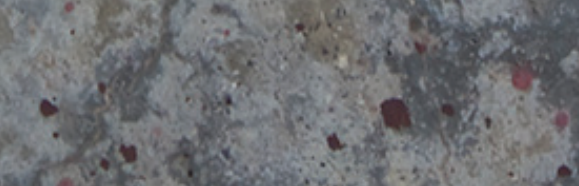

Interessante 

Desde que a arte deixou de ser identificada com as obras-primas, cuja principal categoria era a Beleza, talvez de Duchamp até hoje, o tipo de experiência proposto pela arte não é o conhecimento e o belo como recompensas (tampouco tem a ver com a verossimilhança e a perfeição), o que tem causado certa recusa e estranhamento no espectador. De fato, aquilo que se esperava como experiência estética deu lugar a algo que podemos chamar de "estética generalizada" sem definição clara do sentido da experiência artística e disso parece derivar o tipo de relação que se tem estabelecido entre público e arte contemporânea.

Talvez seja possível localizar no projeto moderno a reconfiguração da experiência estética, centrado nas vanguardas como surrealismo, dadaísmo, construtivismo; tal projeto estava centrado na unificação da arte e da vida, questionando a arte da representação: "Ceci n'est pas une pipe" seria um espécie de exemplo cabal da investida da arte na modernidade.

Dessas transformações deriva a produção considerada "arte contemporânea" que, a despeito de toda a discussão feita em torno dela, ainda parece não ter fornecido uma reposta à questão deixada pela modernidade, que, "pertencente ao estatuto da interpelação, não permite, a bem dizer, que se produza alguma representação que dê conta da figuração da realidade". ${ }^{1}$

Para o público herdeiro de parte da valoração do que seria uma obra de arte, como parte daquele "coeficiente artístico" do qual Duchamp falara, ${ }^{2}$ o tipo de experiência que recobre as indeterminações próprias da experiência contemporânea é uma tentativa de enquadrá-las a partir de categorias da representação que se apresentam obsoletas para o entendimento do tipo de experiência produzida.

A perplexidade torna-se uma das principais formas de enfrentamento da questão da experiência estética dessa arte, dita contemporânea; isso, certamente, diz respeito ao discurso que circula na educação em uma primeira instância, haja visto que há pouca produção no âmbito educacional que toque no tema. Talvez, fruto da dispersão e indeterminação que recobrem essas experiências contemporâneas - que, por mais próximas da realidade e do ambiente dos alunos, escapa às categorias já apresentadas do belo e da cognição e, portanto, afasta-se brutalmente daquilo que é, geralmente, proposto em educação.

Por outro lado, o que também ocorre, tendo como base as visitas às exposições de arte contemporânea que costumo fazer (sempre acompanhada de outros professores, muitas vezes especialistas em arte), costumo observar um efeito que parece se inscrever no que o crítico alemão Boris Groys denomina "cultura do excesso de gosto".

Para Groys, com a crise da representação e dos meios oriunda da modernidade, a arte contemporânea, ao se valer dessas e de outras referências, elevou o estatuto da imagem, sem

1 FAVARETTO, Celso. "Fronteiras da arte e da vida".* Texto apresentado no Simpósio "Deslocamentos e (des) territórios: fronteiras da arte e da vida”. 210. Encontro Nacional da ANPAP, “Vida e Ficção/ Arte e Fricção”, 24-29/09/2012. Publicado em: GERALDO, Sheila Cabo (org.). Fronteiras: arte, imagem, história. Rio de Janeiro: Beco do Azougue/Faperj, 2014, p. 17-3018. p. 18

20 "Ato criador" de Duchamp é tratado no verbete "Releitura”, p. 171 
criar, contudo, hierarquia entre elas, como seu próprio télos. Assim, imagens da cultura erudita, da cultura de massa, marginais e etc, têm o mesmo valor simbólico, configurando uma espécie de democratização das imagens e de sua pluralidade. Com isso, o crítico alemão conclui que

\begin{abstract}
"this excess both stabilizes and destabilizes the democratic balance of taste and power at the same time. This paradox is, actually, what characterizes contemporary art in its totality". ${ }^{3}$
\end{abstract}

O pluralismo que envolve a arte contemporânea, no entanto, incorre sobre algo que o filósofo e ex-diretor cultural do Musée du Louvre, Jean Galard chamou de "mal-estar na imagem". Para Galard, há dois sentidos que tal expressão nos oferece: um primeiro, ligado ao mal-estar que recai sobre toda imagem que coloque em xeque o estatuto da representação (figuração), a verdade da imagem (pela manipulação de meios técnicos novos), pelo desinteresse oriundo de sua superprodução, etc. Mas há também o mal-estar que surge diante da imagem e que é propiciado especialmente por imagens jornalísticas, que cada vez mais capitalizam o horror e a extrema violência. ${ }^{4}$

Tratam-se de imagens que causam um mal-estar dúbio, principalmente as fornecidas pelo fotojornalismo, pois provocam o horror da cena, tomando como exemplo a série de Sebastião Salgado feita em Kabul', mas ao mesmo tempo nos embaraçam pela qualidade técnica. Por um lado, essas imagens denunciam o horror e, por outro, são capitalizadas como "obras de arte" em livros caros e grandes galerias.

Esse é apenas um exemplo que recobre a imagem na arte contemporânea, outro exemplo está ligado ao fetiche da espetacularização do cotidiano, já que essa é uma categoria de imagem que tem, certamente, a maior circulação entre as demais esferas para além da arte.

Disso deriva uma espécie de "trivialização" da imagem, que, segundo Galard, remete à duas perspectivas. A primeira, dentro da historiografia da arte, diz respeito àquilo que é banal, retratos de pessoas simples, feitos por Rembrandt, Caravaggio, e que enfatizam a experiência do que é trivial, no sentido de banal, de desfavorecido. Já com a arte dita contemporânea, vemos uma segunda acepção de trivial, essa que pode nos auxiliar a entender a configuração de um determinado tipo de valoração que essa arte produz.

A trivialidade contemporânea reafirma a perda da aura do objeto de arte, provocando uma espécie de sátira dos mesmos, desprestigiando o objeto de arte. Ao inserir objetos cotidianos e rearranjando-os com algum prestígio - o hambúrguer trivial de Claes Oldenburg tem dimensões suntuosas ${ }^{6}$, "a representação artística do trivial se distingue da 'simples' trivialidade, ao mesmo

3 GROYS, Boris. Art Power. Cambridge: MIT Press, 2008, p. 3.

GALARD, Jean. "Estética e política: mal-estar na imagem. O trivial e sua representação". trad. Cristina Prado. Revista Discurso Discurso, v. 41, n. 41, 2011, p. 29-46, 2011. p. 40. Disponível em: http://<www.revistas.usp.br/discurso/ article/viewFile/68364/pdf_59 $\rightarrow$. Acesso em 01/08/2015.

$5 \quad$ Trata-se de um série de fotografias feitas em 1996, no Afeganistão. Essas imagens exemplificam o que Galard denomina "mal-estar da imagem", pois ao mesmo tempo que detém uma enorme qualidade técnica, conferindo-lhes o estatuto de obra de arte, tratam de atrocidades como as que uma guerra ou a miséria extrema produzem.

$6 \quad$ Claes Oldenburg, expoente norte-americano da Pop Art, conhecido por suas esculturas de dimensões colossais 
tempo em que explora o efeito que sua proximidade, ou semelhança, não deixa de provocar".7

No entanto, essa mesma noção opera uma espécie de redução, uma generalização estética em torno do banal. Tal generalização é distinta daquela que pretendia a modernidade, de uma fusão entre a arte e a vida. Ao contrário disso, nessa modalidade em que vivemos, "a arte renuncia às suas leis internas, no sentido da autonomia da obra de arte, historicamente conquistada no período das vanguardas. A obra passa a ser fruída, ou melhor, consumida sem mediações como dado natural". ${ }^{8}$

No entanto, adverte Galard, os artistas não querem, contudo, que seus trabalhos recaiam na categoria do "divertissement". Porém, desde pelo menos a década de 1960, a arte abriu-se para uma espécie de "ampliação estética", angariando novos olhares curiosos, especialmente diante da promessa de interação e participação tão presentes nas obras desse momento em diante.

Disso deriva uma espécie de "diminuição de sua intensidade", sobre a qual surge a categoria do "interessante", ou seja, "é o triunfo em realidade de uma certa estética difusa, apaziguada, conciliatória, que alguns autores denominam hedonismo: o outro nome da 'felicidade contemporânea', distinta evidentemente do bonheur stendhaliano, entendido como a experiência da infinitude, decorrente da exaltação romântica da faculdade da imaginação, que orientou as vanguardas artísticas". 9

O que vemos na cena contemporânea é a dificuldade que essa fusão generalizada entre arte e vida aponta para uma possível conciliação entre tantas esferas cotidianas, como, por exemplo, a aproximação da arte e do universo fashion. Segundo Celso Favaretto esse efeito produz uma certa "indiferenciação que, como diz Lyotard, ${ }^{10}$ ressalta a maneira com que objetos são exibidos, a estetização das situações artísticas, de modo que o interesse estético deslocase dos objetos, obras, etc. para o comportamentos cultural dos participantes, comum nas instalações e performances". ${ }^{11}$

Com isso, pode-se aventar que esse tipo de experiência que não se identifica com aquela experiência moderna - relacionada ao Belo e às categorias estéticas estáveis e definidas -, causa em seu público uma espécie de frustração ou de "só mais uma experiência", tornandose meramente "interessante" e é por esse motivo que a experiência artística contemporânea não pode prescindir de uma problematização. É também por esse mesmo motivo, pela sua decepcionante investida contra as categorias modernas de apreciação estética, que a arte contemporânea parece não ter lugar na sala de aula.

Entretanto, aponta Favaretto, essa noção de "interessante" não é algo novo, caudatária da noção de sublime em Kant, pois opõe a ideia de contemplação e mercado de arte. Assim, o "interessante" se relaciona a um outro regime estético - o da economia da arte. "O

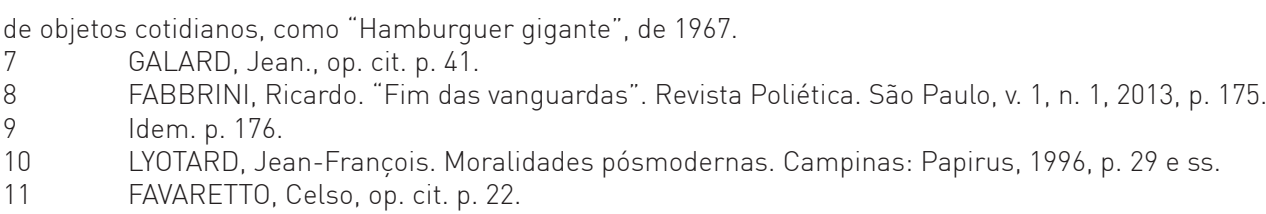


domínio do interessante situa o gosto em um estado de excitação, de insaciabilidade: apoiase numa sensibilidade dos efeitos 'picantes', 'impressionantes', que excita uma sensibilidade embotada, uma imaginação preguiçosa, o estado de indiferença, sugerindo uma expectativa de estranhamento do cotidiano próxima do "curioso" - expectativa que é, contudo, decepcionada". ${ }^{12}$

A expectativa decepciona pois evoca a reflexão. E, ainda, segundo Favaretto, é nesse limiar entre estética e ética que, muitas vezes, a noção de "interessante" passa pela aceitação pura e irrefletida.

Não obstante, são visíveis os esforços envidados para que a categoria do "interessante" não sobreponha e achate a experiência contemporânea, ao modo de Agamben, ou seja, de uma "singular relação com o próprio tempo". ${ }^{13}$ Inúmeros são os artistas e coletivos que propõem uma outra entrada para essa generalização estetizada, inclusive para que essa recaia sobre a vida, numa atitude, muitas vezes, que não se volta aos objetos de arte, mas à própria arte inserida no cotidiano. "Há, nas existências esteticamente bem-sucedidas, diz Jean Galard, uma beleza involuntária que não leva a arte em consideração, mas que requer, entretanto, uma certa arte. Esta é uma via interessante de se pensar, por exemplo, a <arte pública〉, não como uma arte na rua, mas uma arte da rua. Mas a qualificação de <artístico aplica-se «a operações, a um trabalho, cujos resultados não podem ser involuntários». Assim, pode-se falar em <uma experiência estética da paisagem natural, onde a intenção artística é, por definição, ausente ${ }^{\prime \prime} .{ }^{14}$

Talvez seja esse tipo de experiência artística - da suspensão e da reflexão -, que pode ser desenvolvida na educação: em uma época de desencantamento do mundo, a arte pode apresentar uma experiência de resistência ao empobrecimento da experiência dentro da sala de aula. É em torno dessa problemática que Deleuze e Guattari falam da potencialidade da arte em detrimento da cultura da "opinião".

Para os filósofos franceses, "a opinião é um pensamento que se molda estreitamente sobre a forma da recognição: recognição de uma qualidade na percepção (contemplação), recognição de um grupo na afecção (reflexão), recognição de um rival na possibilidade de outros grupos e outras qualidades (comunicação). Ela dá à recognição do verdadeiro uma extensão e critérios que são, por natureza, os de uma "ortodoxia": será verdadeira uma opinião que coincida com a do grupo ao qual se pertencerá ao enunciá-la. (...) A opinião, em sua essência, é vontade de maioria, e já fala em nome de uma maioria". ${ }^{15}$

Nossa sociedade é bombardeada pela opinião, nunca se ouviu tantos especialistas em toda e qualquer esfera da vida (e da arte); eles são convocados para tentar explicar todo e qualquer evento dentro e fora da normalidade, como uma forma de unificar o pensamento que não consegue lidar com o caos, este que representaria a multiplicidade. A opinião é o reino do consenso, do mesmo, da verdade absoluta que é combatida por três ordens do pensamento, como já foi citado: a filosofia e seus conceitos, a ciência, com suas funções e a arte, com seus

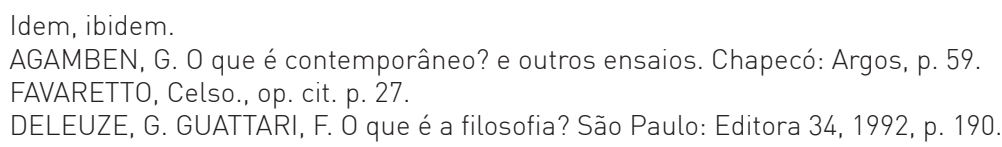


afetos e perceptos, são formas que rasgam o caos, linhas que operam sobre ele, não no sentido de explicá-lo como as opiniões, mas de combatê-las. O que parece garantir à arte sua especificidade e capacidade de desterritorialização na medida em que é cooptada pelo gosto ou pela opinião.

Deleuze e Guattari afirmam que a arte luta efetivamente com o caos, mas com o objetivo contrário à opinião e o bom senso, ela rasga o caos para fazer surgir dali algo que não havia sido visto, sentido. "Quando Fontana corta a tela colorida com um traço de navalha, não é a cor que ele fende dessa maneira, pelo contrário, ele nos faz ver o fundo de cor pura, através da fenda. (...) Uma obra de caos não é certamente melhor do que uma obra de opinião, a arte não é mais feita de caos do que de opinião; mas, se ela se bate contra o caos, é para emprestar dele as armas que volta contra a opinião, para melhor vencê-la com armas provadas". ${ }^{16}$

A arte não seria, portanto, o caos, mas uma composição que teria o caos como forma de desvelamento de uma sensação; eis onde mora a sua maior potência. Se apartado da sala de aula, seja por meio da criação artística, seja por meio de sua deglutição em visitas à exposições, este potencial de rasgo no caos pode ser desperdiçado, e em seu lugar vemos uma inscrição da arte que funciona na reiteração daquilo que é expresso em forma de opinião e de bom-senso.

Portanto, essa categoria do "interessante" que recobre e torna ambivalente a experiência da arte contemporânea aos olhos de uma opinião comum, que cultiva a cultura do gosto, deve ser combatida também na escola, pois ela nada mais reflete do que as expectativas de um tipo público. Parece que o que está por trás dessas expectativas é uma vontade de que a experiência artística venha justamente romper o caos e dar uma espécie de unidade de sentido para uma sociedade tão dispersiva.

Esse tipo de expectativa que a educação parece ter em torno da arte funciona como justificativa que a faz rechaçar a arte contemporânea do seu espaço. Talvez isso se explique pela dificuldade que pode existir em lidar com aquilo que se desconhece e que não apresenta consigo um manual de instruções. Ou seja, a arte contemporânea não chega às escolas possivelmente pelo seu caráter disruptivo, mas também pela manutenção de um certo gosto. 

1. Já acabei, prô.

2. Mas...

3. Precisa mesmo pintar?

4. Qual foi a sua intenção? Viu só...Esqueceu que ela sempre quer saber disso?

5. É isso mesmo, o que eu quero representar é o branco mesmo, o branco puro do papel.

6. Ah! Professora, que saco! Sempre você acha uma coisa que eu não sei responder, eu fiz assim e ponto!

7. O meu trabalho é sobre o papel amassado mesmo, juro.

8. Eu não sei por quê fiz assim, mas eu gostei, estou com pressa.

9. Ah, que preguiça!

10. Arte não é fácil, hein.

Alunos esbaforidos correm a mim constantemente com a frase cabal: "Já acabei!" Quanto mais rápido, melhor. No início eu acreditava que, em todos os casos, tratava-se de falta de interesse nos trabalhos de arte; me questionava, perscrutando minhas falhas, tentando dar mais vivacidade à aula como forma de arrebanhar aqueles que não se interessavam. Depois, comecei a analisar que, para além do desinteresse residia um vestígio espontaneísta, traço que marcou o ensino da arte durante algumas décadas. No entanto, não se tratava de finalizar logo para não fazer nada (claro que sempre haverá diferentes focos de interesse) e sim para começar um novo trabalho. Como se a criação fosse feita em linhas de produção, aceleradamente.

Não foi preciso muito para que eu entendesse que não era a mim que eles se endereçavam, era a si próprios e a possibilidade de poder "fazer aquilo que se deseja". E com isso, abandonei a falsa ideia de que o que eu fazia devia servir a todo mundo com a mesma intensidade. "Não se pode fazer escola, nem fazer parte de uma escola. Só há trabalho clandestino. Só que é uma solidão extremamente povoada. Não povoada de sonhos, fantasias ou projetos, mas de encontros. Um encontro é talvez a mesma coisa que um devir ou núpcias. "1

Para muitos dos meus alunos, o único espaço que lhes é reservado para exercerem seu jeito de fazer, suas escolhas é, infelizmente, a aula de arte. Durante algum tempo eu entendi esse processo dessa maneira. Mas, como configurar a rapidez da produção como parte do processo de pensamento artístico e não apenas como um dado e uma mera constatação.

Percebi que o interesse, independente do tipo de trabalho que estivéssemos desenvolvendo e dos materiais utilizados, quase sempre recaía sobre o "desenho livre". Desenhar livremente é uma herança forte da Livre Expressão². Inicialmente me sentia incomodada com a falta de complexidade em tal proposta. $O$ artista Waltércio Caldas fala que "desenhos são, na maioria das vezes, objetos de papel e alguns acreditam que desenhar é a tarefa mais rápida da arte. Mas a arte se deve muito ao 'quase nada' e desenhos permanecem como sorrisos indo, desprevenidos, em direção ao esquecimento".3

Refletindo sobre o desenho livre - essa situação tão corriqueira que muitas vezes vem

DELEUZE, G. PARNET, Claire. Diálogos. Trad. Eloisa Araújo Ribeiro. São Paulo: Escuta, 1998. p. 6.

Sobre esse momento histórico do ensino da Arte ver o verbete "L". 2007. p. 31

CALDAS, Waltércio. Desenhar. IN: DERDYK, Edith. Disegno. Desenho. Desígnio. São Paulo: Ed. Senac São Paulo, 
preencher a ociosidade da aula de arte - me interessei em pensar sobre aquilo que se apresenta como "quase nada" na arte e, principalmente, qual o lugar disso na sala de aula.

As aulas de arte se configuram, na grande maioria das vezes, em sequências de atividades que têm como objetivo, seja a cada aula, seja ao final do processo, um produto. Invariavelmente, a aula de arte produz produtos.

Marina Abramovic, artista sérvia, talvez uma das mais influentes e reconhecidas da arte contemporânea, em uma instigante entrevista fala sobre seu interesse em colecionar arte. Entretanto, sua coleção conta com obras que não existem. Ou melhor, não existem enquanto objetos, logo, são objetos impossíveis de se colecionar. Não se trata daquele tipo de trabalho difícil de se colecionar, como ocorre com as performances, happenings, site specifics. De qualquer forma, este trabalho pode ser evocado através de seu registro em fotografia ou vídeo. Marina exemplifica o tipo de coleção que lhe interessa: um artista, Gino de Domenicis, vende uma obra invisível a um colecionador. No dia em que foi acordada a entrega da obra, um caminhão pára na porta do prédio do colecionador, seis carregadores descem, avaliam a entrada, medem as portas, e com todo cuidado e luvas brancas carregam uma obra de grandes dimensões até o apartamento. Ao chegar, perguntam onde deveria ser instalada, ouvindo a indicação do colecionador. Dada a fragilidade da obra, os carregadores sugerem um outro lugar, a instalam e vão embora. Pode-se dizer que a obra é a narrativa que se construiu sobre ela.

Ainda parte da coleção de Marina há um "outro trabalho interessante (...)feito por Tino Sehgal, um artista alemão. Ele recebeu o dinheiro e o trabalho vendido foi um sussurro no ouvido do curador". ${ }^{4}$

Marina Abramovic, ao falar de sua coleção, nos apresenta uma dimensão de trabalhos de arte nos quais o que está em jogo não é mais o produto - objeto, e sim a ideia. A partir dessa coleção, comecei a pensar qual era o lugar para o não-objeto, ao "quase nada" na aula de arte, e como trabalhar com arte na escola no nível do discurso por meio da invenção daquilo que não é material.

Ora, todo professor de artes visuais deve ter aprendido algo sobre Marcel Duchamp. Em uma rápida busca na internet é possível encontrar planos de aula de arte em cujo conteúdo consta o artista francês e a sua grande invenção, o readymade. Há ainda diversas receitas de como encaminhar essa aula e produzir finalmente o seu próprio readymade. ${ }^{5}$

No entanto, pouco se fala sobre o acontecimento-Duchamp para além do objeto, pois refletir sob uma perspectiva duchampiana, nos obrigaria a sair, ainda que temporariamente, do domínio retiniano - para falar nos termos do artista - e nos lançarmos ao campo da linguagem e do pensamento, nos quais reside a maior contribuição de Duchamp para a arte. Segundo o artista estadunidense Jasper Johns, "a comunidade artística sente a presença de Duchamp, e sua ausência. Ele mudou a condição de se estar aqui". ${ }^{6}$

\footnotetext{
4 ABRAMOVIC, Marina. IN: OBRIST, Hans. U. Entrevistas. v.6, Belo Horizonte: Cobogó Inhotim, 2012. P. 189. 5 Ver "Fazendo um ready-made". Plano de Aula disponível em: http://educacao.uol.com.br/planos-de-aula/ fundamental/artes-fazendo-um-ready-made.htm. Acesso em 09/07/2015.

6 JOHNS, Jaspers. Marcel Duchamp (1887-1968). IN: FERREIRA, Glória. COTRIM, Cecília. Escritos de artistas: anos 60/70. Zahar, 2006. p. 204.
} 
Ainda para o artista, as possibilidades de rearranjos que o readymade trouxe provavelmente ainda não se esgotaram e, talvez, a maior contribuição de Duchamp, tenha sido inserir a arte "como uma nova unidade de pensamento" e "trazer a dúvida para o ar que envolve a arte".7

A dúvida de que fala Johns, se levada ao contexto escolar, o que pode produzir? De que forma um fazer desinteressado - daqueles que terminam suas atividades sem pestanejar aliado a um desenhar como carro-chefe da aula de arte - poderia dar lugar a uma prática que visasse a construção de um pensamento artístico?

Junto a esse desafio deve-se somar um outro bastante difícil de se propor: experiências em aula que extrapolem a noção de objeto e que ao mesmo tempo incluam na constituição dessa ideia de arte o processo, ou seja, a duração de um trabalho de arte.

Essa lógica dos produtos, no geral, se organizam de duas maneiras diferentes. Uma forma focada em realização de tarefas que duram uma ou duas aulas, por exemplo: desenhar e pintar o clássico disco das cores, ressaltando as primárias, secundárias e terciárias. A outra forma se organiza na ideia de processo, são tomadas algumas aulas, às vezes um bimestre para executar um objeto: construção de uma escultura com papel machê.

Ambas as atividades giram em torno de como o sistema de ensino se organiza, na ideia de tarefas, na maioria dos casos, de repetição e assimilação.

Não obstante, o que Duchamp propõe subverte totalmente essa lógica dentro da arte, abrindo brechas para que existam outros tipos de economias na arte através das quais circulem não mais apenas objetos. Até onde pude apurar, não encontrei essa ideia tão presente na arte veiculada na educação.

Foi tentando propor essa inserção que frases como "o meu trabalho é sobre o papel amassado mesmo" começaram a figurar na sala de aula. Apesar do tom jocoso, esse tipo de resposta vinda de uma criança de nove anos indica que proposições de "se pensar em arte" podem repercutir de formas inesperadas na prática artística dos alunos. Nesse sentido, a ideia de intenção, ainda que contrariando aquilo que fala Duchamp sobre a imprecisão do gesto de criação, passou a fazer parte do vocabulário tanto das crianças menores quanto dos adolescentes.

Ainda que possa soar reducionista, vejo ali, uma chave inclusive muito próxima daquilo que preconizava Duchamp, com a inclusão da linguagem e o discurso sobre a arte, tudo poderia tornar-se um objeto de arte, desde que dentro do espaço próprio da economia da arte. O mesmo parece, em certa medida, ocorrer na sala de aula, uma vez que o discurso da intencionalidade acaba se voltando contra aquilo que pretendia combater: o fazer irrefletido calcado em bases da criatividade espontânea do aluno.

Algo diferente parece se passar quando o dispositivo usado é pensar o trabalho artístico como algo imaterial, na esteira da coleção de Marina Abramovic. Experimentando este dispositivo com os alunos adolescentes, uma gama de questões prontamente se anunciaram e 
se transformaram em ações performáticas, que invadiram o pequeno espaço-tempo da aula de artes visuais e, com alguma coragem, tomaram alguns outros espaços da escola.

A partir de um jogo contendo dois envelopes, um com lugares e outro com ações, que eram sorteados aleatoriamente, os alunos deveriam dar corpo a ações abstratas - tais como reunir uma platéia ou criar um absurdo público - nos locais determinados pelo sorteio. Tudo isso sem recursos próprios do ateliê, ou seja, nada de materiais convencionais da arte. Inúmeras ações foram criadas e problematizadas pelos participantes das performances produzidas. Uma delas, cujo destaque se dá pela censura que sofreu, tratava-se de uma ação sorteada para acontecer no banheiro que deveria criar algum tipo de barreira. O desafio intensificava-se na medida em que não se poderia usar nada que impedisse literalmente a entrada.

Depois de muita discussão, o grupo de cinco alunos de dezesseis anos (que fora aleatoriamente selecionado), decidiu propor uma mudança nas placas dos banheiros: onde via-se feminino ou masculino seria colocada uma placa "unissex". Imprimiram a quantidade de placas exata para o número de banheiros. A discussão passou pelo disciplinamento, pela ideia de construção das diferenças entre os gêneros, pela falta de sentido, para eles, em não poder usar o mesmo banheiro, entre outras coisas.

O ponto alto do trabalho não está no pensamento que produziu, tampouco nas placas impressas, que foram cuidadosamente selecionadas e tinham a mesma cor e desenho de ícone das da escola, mas sim, está no fato desse trabalho ter sido censurado, o que confirmava inúmeras das suspeitas elencada na discussão do grupo. E por ter sido censurado, ou seja, por ter sido impossibilitado de existir, o trabalho tornou-se o que dele se falava, tornou-se um boato. Assim, o trabalho não era mais a concretização do seu projeto inicial, mas a ideia daquilo que transcorreria dele.

Inúmeros são os artistas que operam nessa interface, na qual a obra acontece no discurso sobre ela. Maurizio Cattelan é um deles. O artista autodidata italiano, realizou a 6a Bienal do Caribe, que além de não apresentar nenhuma obra, serviu de férias para seus amigos artistas.

Seus trabalhos podem ser reconhecidos na relação entre boato e informação. Uma de suas obras mais conhecidas, Ninth Hour, de 1999, é um trabalho exemplar disso. O Papa, segundo o artista, deveria ter ficado em pé, mas por problemas técnicos acabou ficando deitado e, de improviso, surgiu a ideia de lançar-lhe um meteorito. No entanto, o artista espalhou o boato que teria sido uma decisão de última hora aquilo que causou certo incômodo, especialmente, por ele ser italiano. Neste caso, há a escultura, porém, o trabalho está envolto numa espécie de mística que acaba sendo incluída e em outros casos, torna-se mais importantes que o próprio trabalho.

Outro exemplo é o caso do artista americano James Lee Byars. Em um de seus trabalhos, em Berna, ele ficava na calçada soprando inspiração para dentro do museu, apenas isso. World Question Center, de 1969 é outro trabalho desse artista que não tem objeto envolvido em sua elaboração. Nessa obra, o artista convidou centenas de intelectuais das mais diversas área para elaborarem questões que eles constantemente se colocavam mas para as quais nunca haviam 
encontrado respostas. "Como nós podemos aprender com as nossas falhas?"8 perguntou o artista Cedric Price.

Essa e tantas outras questões que poderiam nortear aquilo que se faz na aula de arte, na contramão daquilo que se faz com arte na educação, acabam sendo vistas como extravagâncias "interessantes", mas que talvez causassem fissuras no controle do espaço-tempo de uma aula de arte. 


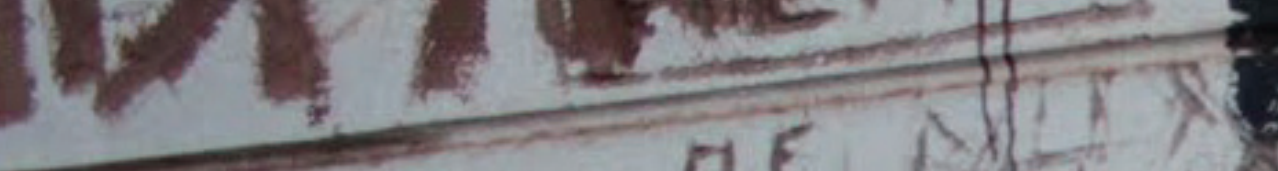

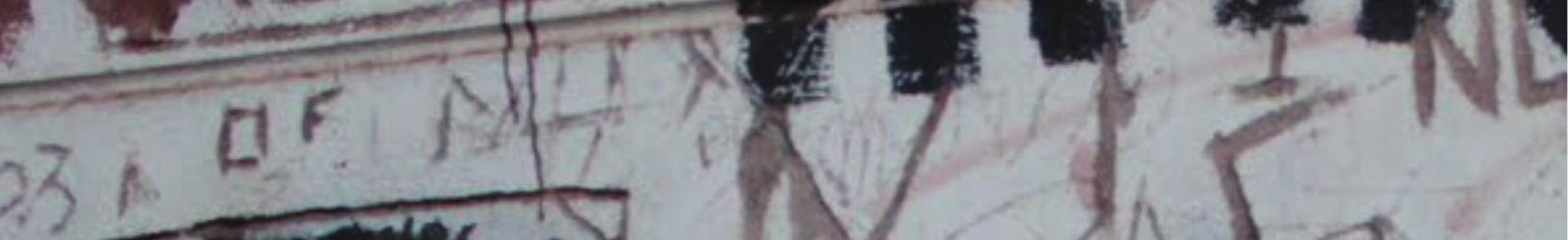

$(4)$

18.

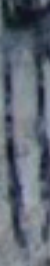

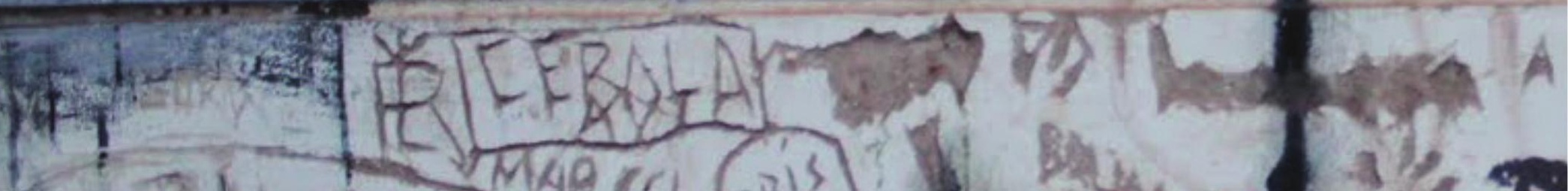

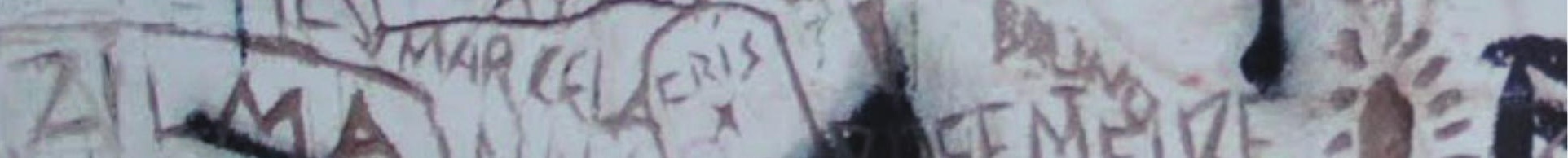

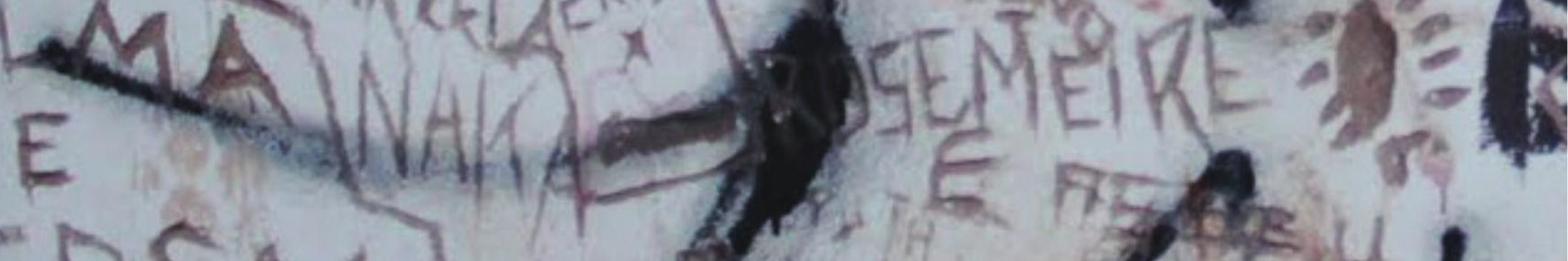

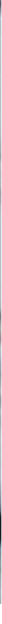




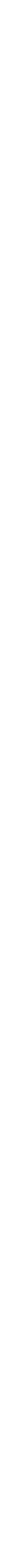



Uma das minhas primeiras iniciativas, depois de lançada à docência, foi fazer um vídeo com os alunos do $6^{\circ}$ ano acerca do que eles consideravam arte e o que, afinal, fazíamos com arte na escola? As respostas foram bastante interessantes, evidenciando a variedade cultural que caracteriza os alunos da Escola de Aplicação da Faculdade de Educação da Universidade de São Paulo. $O$ ingresso ali é feito através de sorteio público, abarcando desde funcionários técnicos aos docentes da universidade e também o público externo, geralmente de áreas de certa vulnerabilidade social do entorno da USP.

O que me chamou atenção neste projeto foi a correlação direta entre arte, beleza e virtuosismo presente nas respostas obtidas. No geral, as noções de arte mais recorrentes eram associadas à habilidade de desenhar, à expressão de sentimentos e à criatividade.

Com algum tempo e algumas experiências pude perceber que essas ideias não eram respostas exclusivas a uma proposição de sala de aula, elas têm aparecido arraigadas nas falas de todas as turmas que lecionei nesses cinco anos de prática docente: nos $2^{\circ}, 4^{\circ}, 6^{\circ}$ e $7^{\circ}$ anos do Ensino Fundamental e em todos os anos do Ensino Médio. De forma que me faz crer que configuram uma espécie de cultura escolar em torno da Arte. Sem pretender generalizar a discussão, no entanto, partindo da minha prática, posso inferir que, com alguma variação, por trás das falas dos alunos, e não só, encontramos uma suposta verdade da arte como liberdade de expressão, exercício da criatividade e, principalmente, do desenho.

Seria ingênuo, pois, pensar que tais noções presentes nos discursos dos alunos são auto-referenciadas. Ao contrário disso, elas são construções de discursos da educação sobre arte, que podemos encontrar em documentos oficiais, nas falas dos professores e na literatura especializada.

Parece haver, sobretudo nos discursos educacionais, um consenso de que arte é um componente importante para a formação do sujeito. Obviamente, não se trata afirmar o contrário, entretanto, é preciso problematizar a questão, visto que apesar das diferentes correntes teóricas em torno da função da arte na educação, algumas práticas se enraizaram e parecem dificultar a inserção de modos de pensar a arte como criação, como transbordamento dos conteúdos e espaços restritos, de pensá-la como um tipo de pensamento que opera mais próxima ao caos do que da ordenação.

Depois do trabalho de vídeo feito apenas com alunos do $6^{\circ}$ ano do Ensino Fundamental, a problemática em torno do que eles sabem sobre arte em todas as séries que leciono foi incorporada como forma de sondar os interesses e diagnosticar com que forças teria que lidar, e que, de fato, são sempre as mesmas. E, sobretudo, havia um desejo de partilhar a ignorância como um caminho a ser percorrido duplamente - pelo professor que parte de onde desconhece e pelo aluno que aceita enfrentar aquilo que ignora.

Esse tipo de operação, em educação, por mais que aparentemente seja aceita e ou até esperada, não é exatamente o que ocorre, conforme descreve o pensador francês Jacques 
Rancière:

normalmente, a relação pedagógica parte da hipótese da desigualdade, mesmo que seja para "chegar" à igualdade. Ora, a relação emancipadora exige que a igualdade seja tomada como ponto de partida. Ela exige que se parta, não do que o "ignorante" desconhece, mas do que sabe. O ignorante sempre sabe alguma coisa e sempre pode relacionar o que ignora ao que já sabe. ${ }^{1}$

Bem, para meus alunos é sabido que arte é expressão - resposta campeã em disparada, possivelmente, relacionada a um momento bastante interessante da história do ensino da arte, conhecido como Livre Expressão. Trata-se de um movimento muito forte na década de 1970, que partia de um grande apelo ao laissez-faire, ou seja, a uma não-interferência do professor no processo criativo dos alunos na aula de Arte, uma vez que o processo de criação deveria ser genuíno e qualquer intervenção poderia influenciar negativamente o aluno. Ao que parece, a Livre Expressão pode dizer algo não apenas sobre a prática docente em Arte, mas também sobre uma crença, por parte dos alunos, na arte como uma espécie de expressão de um estado de inspiração emocional. Dito isso, seria interessante nos perguntar: De que forma essa crença é alimentada pelas proposições em sala de aula? Ou ainda, o que está implícito nesse conceito de arte, no que diz respeito ao trabalho docente?

Historicamente, a Livre Expressão encontra ancoragem na validação (ou invenção) da infância e parte do projeto do movimento Escola Nova ocorrido na Europa e Estados Unidos no final do século XIX, mas que só ganha força por aqui na década de 1930. Com a mudança dos focos de aprendizagem do conhecimento científico-lógico para o entendimento psicológico e subjetivo da criança, inicia-se uma sorte de pesquisas que se usam do desenho para desvelar a interioridade da criança.

No contexto brasileiro, essa abordagem vem de encontro a uma necessidade de se confrontar com as bases rígidas do estatuto do desenho e da cópia, além do uso difundido dos desenhos mimeografados para colorir nas aulas de arte, bem como interage com a discussão e a valorização do desenho da criança proposta por Mário de Andrade, pois para ele as crianças deveriam ter liberdade de expressão, o que significava dizer, naquele momento, que elas pudessem ultrapassar as margens, por exemplo. Além disso, foi Mário de Andrade quem se interessou em decodificar a apreciação de arte para as crianças, o que se liga diretamente à importância que a Arte-educação colocará sobre a leitura de imagem.

Em 1948, vemos o surgimento do movimento Escolinha de Arte, idealizado por Augusto Rodrigues, cujo principal objetivo era o desenvolvimento da capacidade criadora das crianças. Foram as Escolinhas de Arte que promoveram a propagação da livre-expressão como metodologia de ensino da arte. Ainda que instituído fora da educação formal, este tipo de pensamento contagiou também os professores das escolas formais como uma espécie de alento frente a

1 RANCIÈRE, J. IN: VERMEREN, Patrice; CORNU, Laurence; BENVENUTO, Andrea. Atualidade de o mestre ignorante. Revista Educação e Sociedade, v. 24, n. 82, p. 185-202, 2003.

Disponível em: http://www.scielo.br/pdf/es/v24n82/a09v24n82.pdf. Acesso em 14/06/2015. p. 187. 
rigidez do desenho técnico, geométrico e pedagógico, principais atividades da aula de arte.

Junta-se a isso a valorização do desenho infantil que "provocou a resultante metodológica de retirar os modelos externos das aulas de desenho, levando a uma busca e enriquecimento dos modelos internos". Entretanto, os modelos que foram sendo criados, ainda assim eram baseados nas ideias de John Dewey e se desenvolveram a partir do seu princípio "da função educativa da experiência, cujo centro não é nem a matéria a ensinar, nem o professor, mas sim o aluno em crescimento ativo, progressivo". ${ }^{3}$ De forma que reconduzido à sala de aula, esse princípio tornouse rapidamente palavra de ordem contra a interferência no processo criador de cada aluno.

Ao professor cabia apresentar os materiais e assistir ao espetáculo virtuoso da criação artística. Noção que aparece bem clara no preconceito dos professores de outras disciplinas "mais estruturantes", como propagam alguns de meus colegas de trabalho, já que é "só dar um pincel e tinta na mão dos alunos que eles se divertem"!

Ainda que esse tipo de frase pareça trivial, fala sobre, inclusive, a inserção da arte como componente curricular afeita ao sensível, como uma espécie de contraponto tensional ao rigor cientificista, com "uma clara intenção de matizar os efeitos, na formação, no indivíduo e na cultura, dos excessos da racionalidade instrumental". ${ }^{4}$ Lugar, portanto, onde os alunos podem "relaxar" as tensões trazidas pelo conhecimento racional e científico.

Em conjunção a esse estigma, nosso legado da arte como expressão, nos coloca em sala de aula numa "sinuca de bico", pois a afirmação por parte dos alunos de que arte é expressão dos sentimentos parece ter dupla função: uma é assegurar um fazer despretensioso (aparece especialmente na fala dos adolescentes) e outra é propiciar um discurso sem reflexão sobre arte.

Além de apresentar no interior da escola uma noção de arte como expressão subjetiva, a Livre Expressão trouxe no seu bojo um laço que permanece ainda muito bem dado na cultura escolar em torno das aulas de arte: arte como criatividade.

Nos Parâmetros Curriculares Nacionais encontramos uma crítica fundada na identificação entre criatividade e livre expressão, pois a criatividade poderia estar presente no currículo de qualquer disciplina, não sendo exclusividade da arte, no entanto, quando no mesmo documento nos atentamos aos objetivos gerais da disciplina, encontramos "a resolução de problemas por meio da criatividade". 5

Nesse ponto é preciso fazer uma importante diferenciação, visto que venho defendendo uma poética da aula de arte que privilegie a criação, mas não vista como criatividade. Ou seja, não é pela chave que geralmente se opera na escola - arte como monopólio da criatividade, e sim de uma maneira bem simples, "a criatividade (isto é, a criação de soluções originais para problemas já dados), apenas, como uma parte do processo de criação; o qual é mais amplo e envolve a invenção dos próprios problemas". ${ }^{6}$

BARBOSA, Ana Mae. Arte-educação no Brasil. p. 112

FERRAZ, M FUSARI, M. Arte na Educação Escolar. p 36

FAVARETTO, Celso. Arte contemporânea e educação. p. 228

BRASIL. Secretaria de Educação Fundamental. Parâmetros curriculares nacionais : arte / Secretaria de Educação Fundamental. - Brasília : MEC/SEF, 1997. p. 21

6 CORAZZA, Sandra Mara. A formação do professor-pesquisador e a criação pedagógica. In: Revista da FUNDARTE. 
Esse tipo de proposição remonta ao trabalho de Albers e Kaprow e que pouco se difere da ideia de criação deleuziana, como operação do pensamento análoga ao trabalho da filosofia cuja finalidade é a criação de conceitos, porém o que se cria são afectos e perceptos, mas que evidentemente no contexto escolar passa menos pela construção desses afetos como obras de arte e mais pela experimentação de afectos e perceptos disparados pelo professor, em suas situações-problema e suas proposições cujo objetivo-fim, lembrando o que diz Albers seria um aprendizado do olhar, do sentir e do fazer.

Também nesse ponto, a postura do professor que partilha o que desconhece, rememorando mais uma vez Rancière, poderia ser confundida com a posição defendida na livreexpressão como uma não-interferência no trabalho de aula. Pois, para o pensador a tarefa da emancipação intelectual, no nosso caso, poderia ser vista como uma espécie de emancipação ou autorização sensível da intelectualidade - via corpo, olhar, proposições que extrapolem o comum - é requerida pelo aluno, num tipo de relação que é sempre individual.

A não-intervenção praticada no ensino da arte pela Livre-Expressão, partindo da premissa que o aluno detém o seu próprio processo, apesar de não se opor radicalmente ao pensamento de Jacotot via Rancière, poderia aprender com algumas de suas lições.

Jacques Rancière, ao escrever $\mathrm{O}$ mestre ignorante, resgata e faz uso do método desenvolvido pelo pedagogo Joseph Jacotot, desenvolvido quando o mesmo foi lecionar literatura francesa na Holanda, sem saber falar holandês e sem que seus alunos tampouco soubessem francês. Na tentativa de não embrutecer seus alunos com a prepotência do conhecimento e sem vontade de aprender o idioma deles, Jacotot procurou por algo que os unisse.

Rancière escreve esse livro no auge do debate intelectual sobre a reforma da escola pública francesa da década de 1980, como uma forma de fazer aquilo que parecia tão descabido e obsoleto do século XIX ranger com as convicções da pedagogia das explicações - na qual o professor é o detentor de um saber que deve ser explicado ao seu aluno (ignorante).

Apresentar brevemente esse debate pode fornecer lastros daquilo que se passa ainda hoje na educação e que assola tanto uma crítica das metodologias, como é o caso da Livreexpressão, quanto das tantas metodologias de ensino da arte, pois por mais antagônicas que elas possam parecer, há um ponto que as aproxima que é a centrado na ideia do professor explicador, no segundo caso e no primeiro, do professor autoridade.

O que parecia estar em jogo naquele debate, segundo Rancière, era a oposição entre duas vertentes de acesso ao conhecimento, a saber: uma inspirada em Bourdieu que "privilegiava as formas de adaptação do saber às populações desfavorecidas, ao pensamento dito "republicano", que insistia sobre a difusão indiferenciada do saber, como instrumento de igualdade".7

As duas posições partiam da ideia de que o saber é constituído através da igualdade. No entanto, Rancière apresenta o modelo de emancipação intelectual proposto por Jacotot, que parecia dissolver as teses apresentadas por republicanos e sociólogos, pois por trás dessa

- ano.1, v. 1, n.1 (jan.-jun. 2001) - Montenegro : Fundação Municipal de Artes de Montenegro, 2001-. p. 14.

$7 \quad$ RANCIĖRE, Jacques., op. cit. p. 186. 
polêmica "há de fato a oposição entre aqueles que tomam a igualdade como um ponto de partida, como um princípio a ser atualizado, e aqueles que a concebem como um objetivo a ser atingido por meio da transmissão de um saber". ${ }^{\circ}$

A tese de Jacotot se difere das demais, pois ela pressupõe uma igualdade das inteligências. Caso contrário, mesmo um mestre que não tem a língua como elemento de igualdade, ao dar uma ordem é capaz de ser entendido. No entanto, ainda que seja uma suposição que valha, inclusive, para corroborar com as teses republicanas ou sociológicas, acaba sucumbindo a uma falta, a verificação da desigualdade. Todo o sistema de ensino é calcado na ideia do professor como explicador, "a explicação não é outra coisa que a invenção da incapacidade do outro. Explicase, pois se tem criado com antecedência um incapaz que precisa da explicação. A invenção da incapacidade do outro é o que permite o nascimento da figura do explicador. O mestre é esse explicador que tem inventado ao incapaz para justificar a sua própria explicação. Assim sendo, o explicador e o incapaz constituem o binômio inseparável de todas as pressuposições pedagógicas, atuais e passadas". 9

Não é muito difícil de perceber que atualmente a experiência pedagógica continua funcionando por razões de desigualdade, ainda que haja discursos em torno da igualdade das inteligências, geralmente, estas inteligências são usadas para aferir e propor suas inferioridades e superioridades.

Do outro lado, operando em outra lógica, estaria Jacotot - o mestre ignorante e emancipador - que se opõe à ideia de desigualdade e à lógica da explicação a favor de um trabalho de emancipação do outro, apostando na sua capacidade de aprender o que quiser, segundo uma lógica da vontade e do desejo do outro. Portanto, para Rancière, Jacotot não pretendia fazer escola, para ele a igualdade não é uma forma, é "fundamental e ausente, atual e intempestiva, sempre dependendo da iniciativa de indivíduos e grupos que, contra o curso natural das coisas, assumem o risco de verificá-la, de inventar formas, individuais ou coletivas, de sua verificação". ${ }^{10}$

O mestre ignorante, portanto, ajuda o emancipado a encontrar seus problemas e tão logo que esteja posto, se retira do jogo e "diz ao candidato à emancipação: o problema é seu, eis aqui esse livro, eis aqui a oração, eis aqui o calendário, eis aqui o que tens a fazer, observa os desenhos nessa página, diz o que podes reconhecer aí etc". ${ }^{11}$

Portanto, voltando ao tema da arte na educação, não se trata nem de uma aposta ou de outra. Não interferir naquilo que o aluno está fazendo é, na melhor das hipóteses, uma versão apressada do emancipador, pois poderia se relacionar com a ideia de que o professor não tem nada a ensinar, no entanto, ele é a figura que apresenta os dispositivos - materiais, proposições,

SKLIAR, Carlos. Jacotot-Rancière ou a dissonância inaudita de uma pedagogia (felizmente) pessimista. Educ. Soc., Campinas, v. 24, n. 82, p. 229-239. Apr. 2003. Available from $<$ http://www.scielo.br/scielo.php?script=sci arttext\&pid=S0101-73302003000100013\&lng=en\&nrm=iso $\rightarrow$. access on 14 July 2015. http://dx.doi.org/10.1590/S010173302003000100013

10 RANCIĖRE, Jacques. “O mestre ignorante.” p. 16.

11 RANCIĖRE, Jacques. In: VERMEREN, Patrice; CORNU, Laurence; BENVENUTO, Andrea. Atualidade de o mestre ignorante. p. 192.
} 
lança problemas etc. Não alguém que assiste o processo de criação. É por isso que Jacotot fala sobre a mediação - o mestre emancipador estabelece uma relação individual com as vontades de seus alunos. E, por outro lado, autenticar uma prática em arte totalmente calcada na explicação, afirmando a desigualdade entre as inteligências e submetendo o próprio do fazer artístico enquanto criação ao julgo do outro. Nesse sentido, nem a rubrica da Livre-expressão nem a da arte-educação parecem levar em conta em seus discursos aquilo que segundo Rancière está no centro da emancipação, e especialmente, num processo de criação - o desejo de aprender, o desejo de criar. 



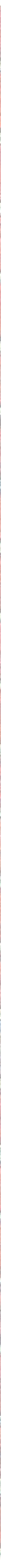




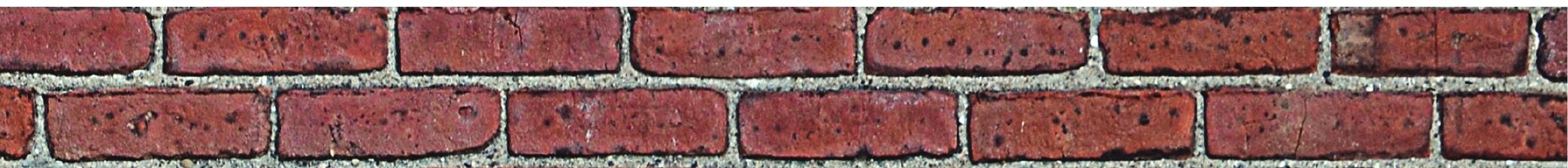
- -3

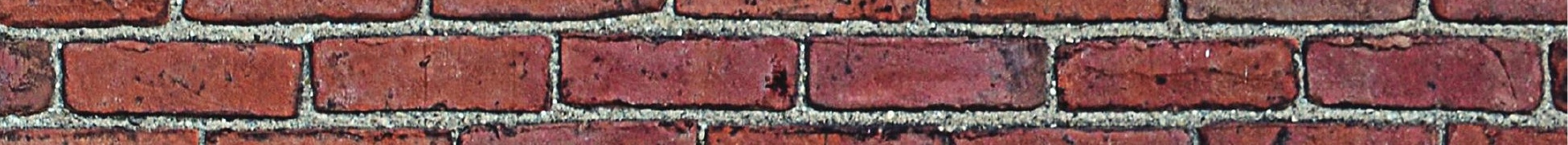
$x+5$

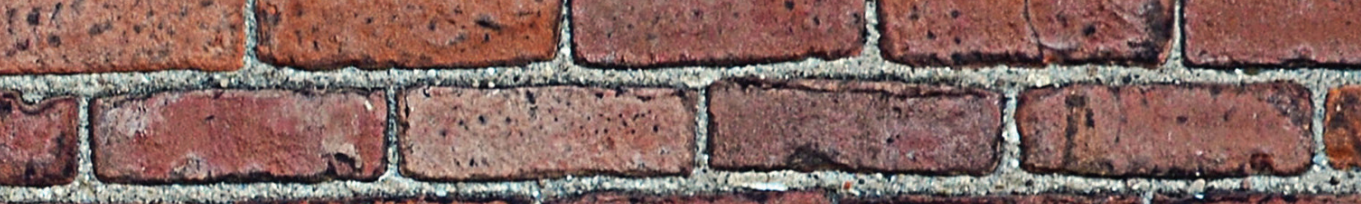
icose -<smiles>[Tl]</smiles>

r.

Il<smiles>c1ccccc1</smiles><smiles>c1ccccc1</smiles><smiles>C1=CC=C1</smiles><smiles>[Tl]C1CCCCC1</smiles><smiles>c1ccc2ccccc2c1</smiles>

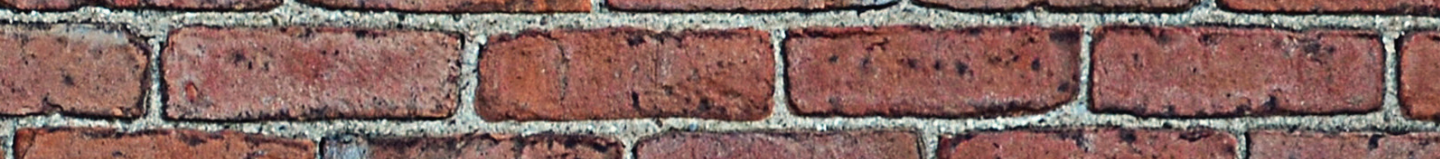

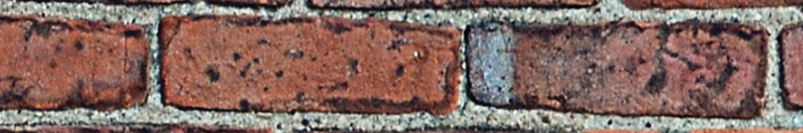

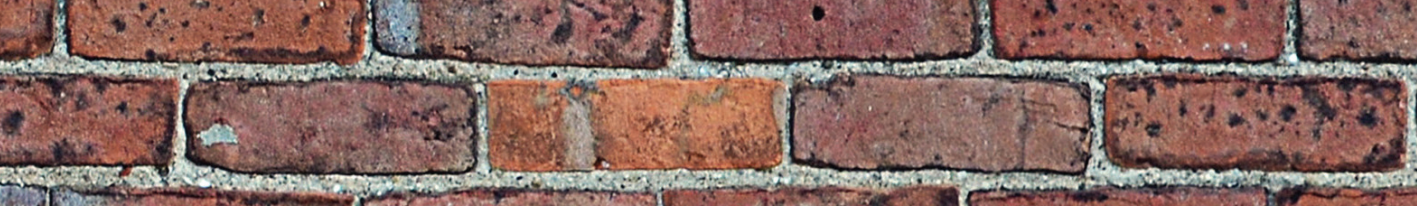

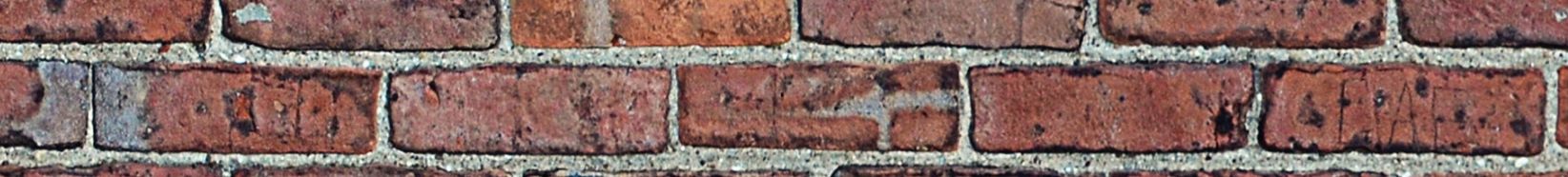

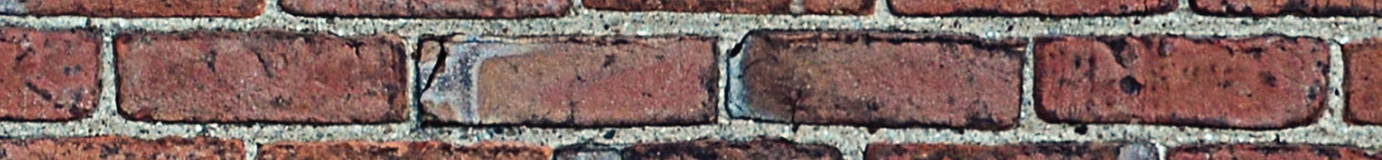
Xe the wa

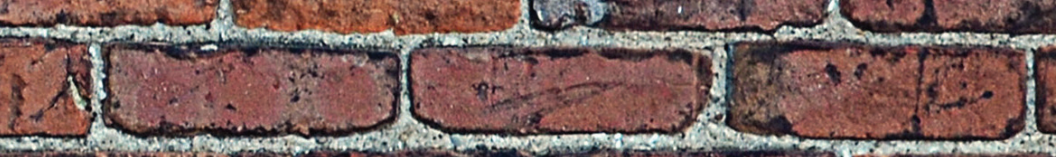
$-1$ 3.

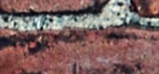
ग्र 2 Magn C. Máquima do Mundo IL

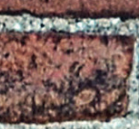

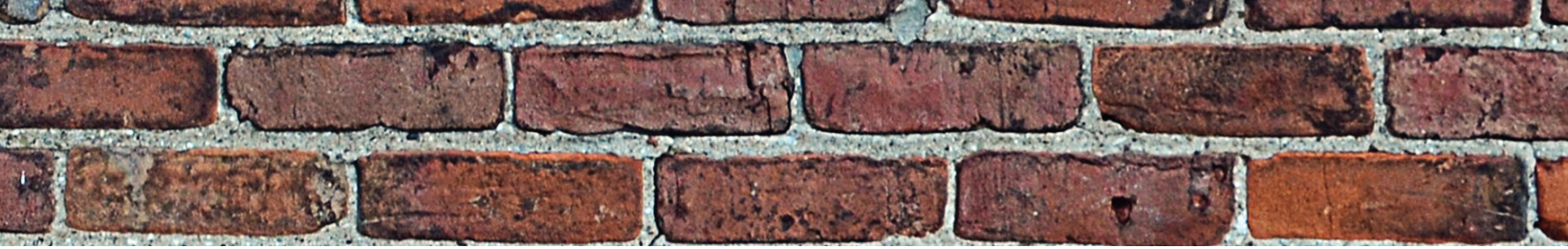

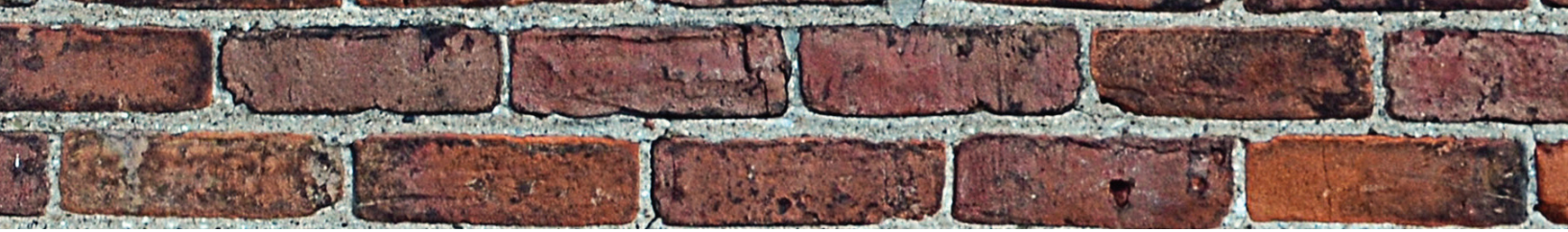
a) $11 \frac{5}{125}$

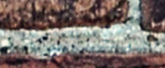

d.

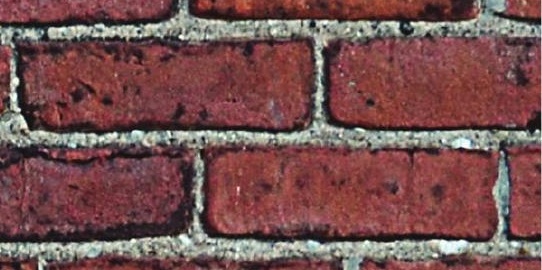



Sob a pergunta "por que ainda a escola é refúgio, por excelência, do esperado, do mesmo?"1 comecei a fabular uma outra escola - para alem da ideia de zona de passagem, na qual além de pessoas, movimentam-se conteúdos, afetos. Passam-se horas, dias, anos, e ainda assim, numa análise pessimista pouca coisa parece se transformar neste espaço no que diz respeito aos modos de fazer e de propor a circulação da aprendizagem em geral, e como é tratado em outros verbetes, da arte em particular.

A propaganda da rede municipal de educação do Rio de Janeiro do ano de 2015 é bastante reveladora de como a política do Estado entende a educação: uma plataforma deslizante de pessoas, numa espécie de linha de produção. Trata-se ainda, da velha concepção de um tipo de subjetividade centrada no "eu" universal, pressuposto de um compartilhamento possível entre todos, ideia fundante da modernidade a qual Deleuze e sua filosofia da diferença não cessa de atacar, tentando liberar, sobretudo, o pensamento da prisão do senso comum, daquilo que the quer conferir uma forma única. A imagem desta propaganda não quer nem ao menos esconder que para a educação de massa o que é fornecido é uma esteira rolante, na qual as crianças todas iguais, permanecem sentadas, receptoras passivas da aprendizagem.

A artista brasileira Laura Vinci, em uma instalação que usa também uma máquina com uma esteira rolante, na qual um tipo de pó branco é transportado de um lado ao outro no espaço expositivo, apresenta elementos formais parecidos com os utilizados na propaganda, porém com uma outra leitura, mais crítica. Apesar de tratar mais fortemente da questão do excesso de "brancura" e mesmice nos espaços e discursos da arte contemporânea, dentro do chamado "cubo branco", essa mesma ideia poderia ser associada também ao que acontece nos modos como a escola se configura, como uma arrefecida passagem do mesmo.

Essa instalação tem como referência já em seu título, o poema do consagrado Carlos Drummond de Andrade:

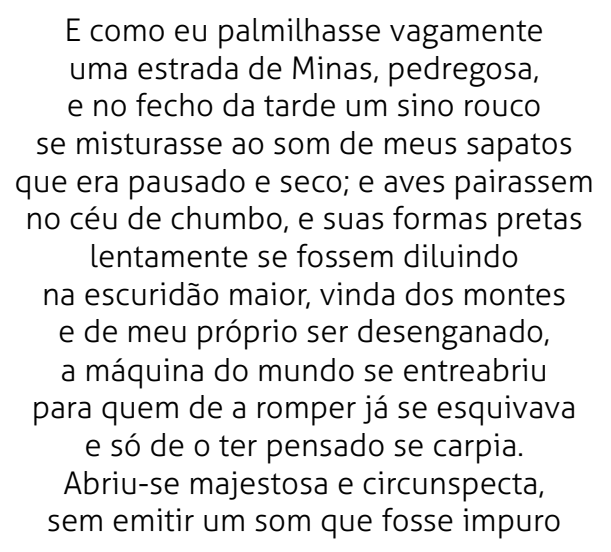

1 LOPONTE, Luciana Gruppelli. Docência artista: arte, estética de si e subjetividades femininas. Orientação: Prof Dra. Rosa Maria Bueno Fischer. Porto Alegre: UFRGS, 2005. (Tese de Doutorado). p. 19 
nem um clarão maior que o tolerável pelas pupilas gastas na inspeção contínua e dolorosa do deserto, e pela mente exausta de mentar toda uma realidade que transcende a própria imagem sua debuxada no rosto do mistério, nos abismos.

Abriu-se em calma pura, e convidando quantos sentidos e intuições restavam a quem de os ter usado os já perdera e nem desejaria recobrá-los, se em vão e para sempre repetimos

os mesmos sem roteiro tristes périplos, convidando-os a todos, em coorte, a se aplicarem sobre o pasto inédito da natureza mítica das coisas, assim me disse, embora voz alguma ou sopro ou eco ou simples percussão atestasse que alguém, sobre a montanha, a outro alguém, noturno e miserável, em colóquio se estava dirigindo: "O que procuraste em ti ou fora de teu ser restrito e nunca se mostrou, mesmo afetando dar-se ou se rendendo, e a cada instante mais se retraindo, olha, repara, ausculta: essa riqueza sobrante a toda pérola, essa ciência sublime e formidável, mas hermética, essa total explicação da vida, esse nexo primeiro e singular, que nem concebes mais, pois tão esquivo se revelou ante a pesquisa ardente em que te consumiste... vê, contempla, abre teu peito para agasalhá-lo".

As mais soberbas pontes e edifícios, o que nas oficinas se elabora, o que pensado foi e logo atinge distância superior ao pensamento, os recursos da terra dominados,

e as paixões e os impulsos e os tormentos e tudo que define o ser terrestre ou se prolonga até nos animais

e chega às plantas para se embeber no sono rancoroso dos minérios,

dá volta ao mundo e torna a se engolfar, na estranha ordem geométrica de tudo, e o absurdo original e seus enigmas, suas verdades altas mais que todos monumentos erguidos à verdade: e a memória dos deuses, e o solene sentimento de morte, que floresce no caule da existência mais gloriosa, tudo se apresentou nesse relance e me chamou para seu reino augusto, afinal submetido à vista humana. 


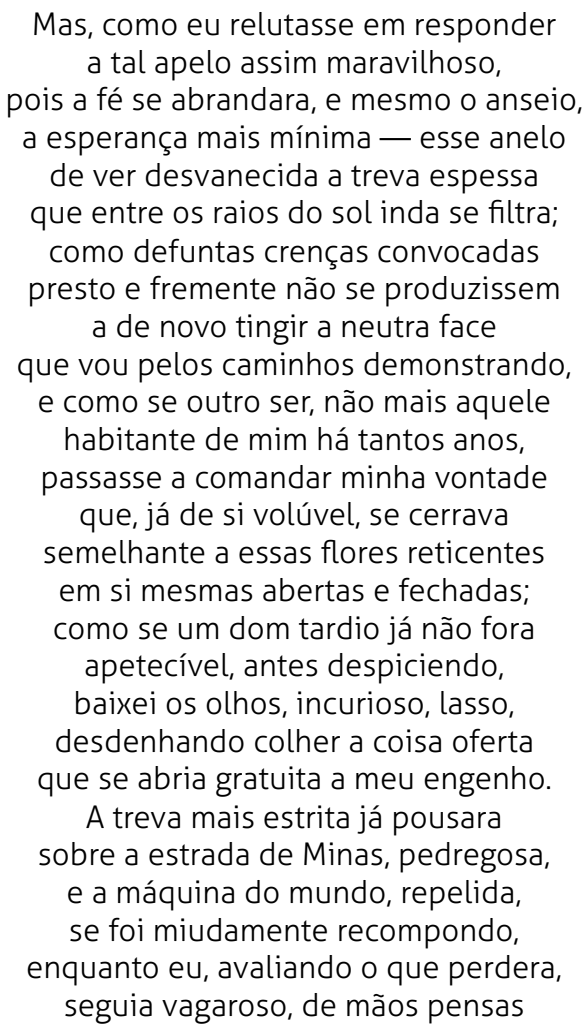

As três imagens associadas podem nos fornecer um rápido panorama da escola. A esteira da fábrica na propaganda do Rio apresenta a crença por trás da configuração estrutural da escola: por disciplinas segmentadas, graus diferentes de dificuldade, idade/série, etc. O aluno é portanto um receptáculo do conhecimento que vai deslizando pela esteira, ao final do processo tem como mérito a aquisição do conhecimento, com pouca ou nenhuma relação com o mundo exterior sob a prevenção de que um dia aquilo poderá ser usado para alguma coisa. A máquina de Laura Vinci, por sua vez, oferece uma imagem da repetição desvitalizada das operações na escola. 0 professor que leva de um lado ao outro, a mesma substância, da mesma forma, mecanicamente, com o que só se vê tédio. Por fim, o diagnóstico cada vez mais comum na escola de recusa, de desistência por parte dos alunos, pode ser visto na decisão empreendida por Drummond de renegar o conhecimento que the é ofertado sob a roupagem da desvelação de grandiosos e preciosos segredos. Talvez os alunos não queiram esse conhecimento ou não dessa forma.

Essa imagem - de recusa -, tão presente em tantos alunos de diferentes idades, pode também ser ilustrada por Ernesto, um personagem de Chuva de Verão, de Marguerite Duras, que inspirou o curta-metragem francês En rachâchant², de 1982, dirigido por Jean-Marie Straub e Danielle Huillet. O filme é uma ácida crítica ao sistema de ensino como a condição suprema de se viver na sociedade, apresentado neste curta como uma presunçosa, conservadora e 
absolutamente arbitrária noção de conhecimento.

O garoto de cerca de dez anos, chega em sua casa e canta docemente aos seus pais sua nova decisão: não frequentar mais a escola, pois ali não se ensinam coisas que ele não saiba.

De partida, na escola, ao ser questionado pelos pais se conhecia seu filho Ernesto, o professor, sem rodeios, diz que não se recorda. Um primeiro nível da crítica, nesse breve diálogo se apresenta. A escola como linha de produção não se interessa de fato pelas multiplicidades e singularidades que compõem seus alunos. A própria condição de aluno basta para configurar um tipo de subjetividade encarada na escola. Já diante do professor, encontram-se a mãe, o pai e Ernesto, que começa a ser interrogado sobre tal decisão demonstrando que ele sabe muito pouco. $\mathrm{O}$ garoto impassível responde às perguntas sem qualquer interesse nas respostas esperadas, assim, uma borboleta ressecada para ele significa um crime.

Apesar de toda a coação, Ernesto diz que inventará um método novo para aprender, que dá título ao curta-metragem, e afirma, ao ser questionado como ele pensa que irá aprender, serena e silabicamente o pequeno rapaz responde: "I-ne-vi-ta-vel-men-te!".

O curta-metragem é uma excelente analogia àquilo que Deleuze designa pensar. Para o filósofo, o pensamento nada mais é do que a criação dos próprios problemas, e portanto, ele é passível de ocorrer a todo momento em que houver necessidade. É fruto do estranhamento entre as formas e coisas já conhecidas e a aquisição de uma nova sensibilidade sobre algum signo signo em Deleuze não se restringe ao campo linguístico. ${ }^{3}$ Não há como evitar a vida, assim como é vital que se aprenda. Importante lição para a educação.

Eis uma dupla crítica, primeiro à escola como o lugar exclusivo de aprendizagem e em segundo ao pensamento como uma imagem da árvore, que vai crescendo com o passar dos anos, da copa e toda a superfície para se aprofundar nas raízes, ou seja, o conhecimento é sempre hierárquico e deve ser especializado. ${ }^{4}$

De volta a imagem de esteira da propaganda - escola como uma esteira, seria oportuno em seu lugar associar um outra imagem: plataforma ou como usam Deleuze e Guattari a ideia de platô: "está sempre no meio, nem início nem fim". ${ }^{5}$ Junto a essa plataforma, faço a proposição de pensar uma inscrição da arte na escola com a forma de uma máquina de guerra em oposição a educação como um aparelho do Estado.

Deleuze e Guattari, especificamente, no décimo segundo de seus platôs, intitulado 1227 - Tratado de nomadologia - a máquina de guerra traçam a criação do conceito de máquina de guerra. Esse conceito interessa a essa pesquisa, pois ele nos fornece elementos para trocar essa imagem de esteira da fábrica, rolante e estriada pela imagem de plataforma lisa e derrapante.

A noção de território, de constituição do espaço geográfico é salutar para o entendimento do conceito da máquina de guerra, e aparece em diversas passagens dos platôs. O território,

\footnotetext{
3 Sobre o problema da criação ver o verbete " $Z$ ".

Deleuze e Guattari exploram a ideia de conhecimento, mundo e o pensamento como imagem através da imagem da árvore no primeiro platô. DELEUZE, G. GUATTARI, F. Mil platôs: capitalismo e esquizofrenia. v.1. p. 23 - 41.

$5 \quad$ Idem, ibidem. p. 32
} 
segundo Deleuze, "é o domínio do ter(...) e sair do território é se aventurar". ${ }^{6}$ Assim como a noção de Estado, povos e bandos nômades são cruciais para a composição de tal conceito.

O conceito "máquina de guerra" nasce da problematização sobre a guerra e sobre o Estado. Deleuze e Guattari se debruçam sobre estudos etnológicos que apontam para a existência de Estado e guerra nas civilizações mais antigas, contrariando a tese que teriam surgido com desenvolvimento econômico.

Ainda que não sob a forma de Estado imperial, o aparelho de Estado existiu nas mais variadas sociedades primitivas na figura do chefe, cuja função era e ainda o é de capturar, cooptar, assujeitar, enquadrar. Nesse contexto que surgem as máquinas de guerra, ao contrário do que pode-se supor, a máquina de guerra não é fruto da guerra.

A historiografia costuma atrelar a máquina de guerra a um estatuto militar, assim como costuma encarar os nômades, os inventores das máquinas de guerra, sem quase nenhum interesse (uma formação pré-feudalista) em detrimento do triunfo das organizações de Estados imperiais. Seguindo o trilho proposto pelos filósofos é impossível pensar o conceito de máquina de guerra sem falar sobre os nômades - seus inventores.

Os nômades não tem história, apenas geografia, apontam Deleuze e Guattari. O nômades se diferenciam em absoluto dos migrantes, pois eles estão em constante movimento, enquanto os migrantes vão de um ponto ao outro, e a reterritorialização se faz quando chegam. Os nômades são a desterritorialização que não finda, o nômade se reterritorializa na desterritorização, eles são o meio. Os trajetos existem, no entanto, "o ponto de água só existe para ser abandonado".7

O espaço do Estado é o espaço da gravidade, da ausência de movimento, do sedentário, é estriado por muros, casas, cidades, países, etc. Enquanto "o espaço liso é um campo sem condutos nem canais. Um campo, um espaço liso heterogêneo, esposa um tipo muito particular de multiplicidades: as multiplicidades não métricas, acentradas, rizomáticas, que ocupam o espaço sem "medi-lo", e que só se pode explorar "avançando progressivamente". 8

O pensamento nômade difere do pensamento do sujeito universal, "ao contrário, invoca uma raça singular; e não se funda numa totalidade englobante, mas, ao contrário, desenrola-se num meio sem horizonte, como espaço liso, estepe, deserto ou mar. Estabelece-se aqui outro tipo de adaptação entre a raça definida como 'tribo' e o espaço liso definido como 'meio'".9

Deleuze e Guattari se interessam pelas máquinas de guerra e nas constituições nômades, pois elas cumprem a função de resistir no embate direto com a forma-Estado e ao mesmo tempo apresentam outros modos de vida rechaçados e apagados pela história.

A máquina de guerra tem, portanto, um caráter combativo, ela é exterior ao Estado e à guerra, mas ela é antes de tudo afetiva. "O afecto é a descarga rápida da emoção, o revide, ao passo que o sentimento é uma emoção sempre deslocada, retardada, resistente. Os afectos são projéteis, tanto quanto as armas, ao passo que os sentimentos são introceptivos como as

DELEUZE, Gilles. PARNET, Claire. Abecedário.

DELEUZE, G. GUATTARI, F. Mil platôs: capitalismo e esquizofrenia. v.5. p. 50

Idem, ibidem. p. 38

Idem, ibidem. p. 49 
ferramentas". ${ }^{10}$

Para mudar o lugar do pensamento dentro da educação; para que a escola seja o lugar daquilo que não se sabe, sem a promessa de grandes descobertas canonizadas em detrimento do pueril, do menor e daquilo que incomoda são necessárias as máquinas de guerra. Ernesto construiu uma, Jacotot descrito por Rancière montou outra, e não há dúvidas de que diariamente, seja na recusa do discurso "psi" do "aluno-problema", seja naquilo que escapa aos diagnósticos medicalizados dos mais diversos transtornos de atenção-hiperatividade etc. resistem máquinas de guerra.

A tarefa da máquina de guerra é colocar o pensamento em contato com o seu fora, com o desconhecido, é do desfazimento e não da edificação. Uma "máquina de mundo" deve ser construída na escola em oposição ao aparelho do Estado escolar que constitui um mundo com sujeito e objeto determinados e controlados. Trata-se de resistir, pois "escolas ou instituições especiais: é uma invenção própria da máquina de guerra, que os Estados não deixarão de utilizar, de adaptar a seus fins, a ponto de torná-la irreconhecível, ou então de restituí-la sob uma forma burocrática de estado-maior, ou sob uma forma tecnocrática de corpos muito especiais, ou nos "espíritos de corpo" que servem o Estado, mas também lhe resistem, ou entre os comissários que duplicam o Estado, mas igualmente o servem". ${ }^{11}$

É por esse motivo que não se almeja a construção de um novo mundo, tampouco, buscase a transcendência, trata-se sobretudo de criar linhas de fuga, "que consiste menos em fugir de uma situação do que em 'fazê-la fugir', em explorar as pontas de desterritorialização". ${ }^{12}$

A principal questão, que talvez encontre na arte a sua melhor resposta, é como fazer a educação escapar ao aparelhamento do Estado, pois "sem dúvida, cada vez que um Estado se apropria da máquina de guerra, tende a aproximar a educação do cidadão, a formação do trabalhador, o aprendizado do soldado".13

A arte seria um dos caminhos do motim, vista como disciplina indisciplinada, sem conteúdos rígidos e prévios, é a máquina de guerra ressuscitada, investindo contra o aprisionamento do pensamento que a educação - aparelho do Estado - impõe. Deleuze e Guattari alertam: "cada vez que há operação contra o Estado, indisciplina, motim, guerrilha ou revolução enquanto ato, dir-se-ia que uma máquina de guerra ressuscita, que um novo potencial nomádico aparece, com reconstituição de um espaço liso ou de uma maneira de estar no espaço como se este fosse liso". ${ }^{14}$

Disso deriva a importância do nomadismo em ato, dentro da educação. O pensamento nômade que não busca senão abandonar o ponto de água e colocar algo em seu lugar, já que "esse abandono não implica, necessariamente, um movimento em direção a um outro lugar, mas,

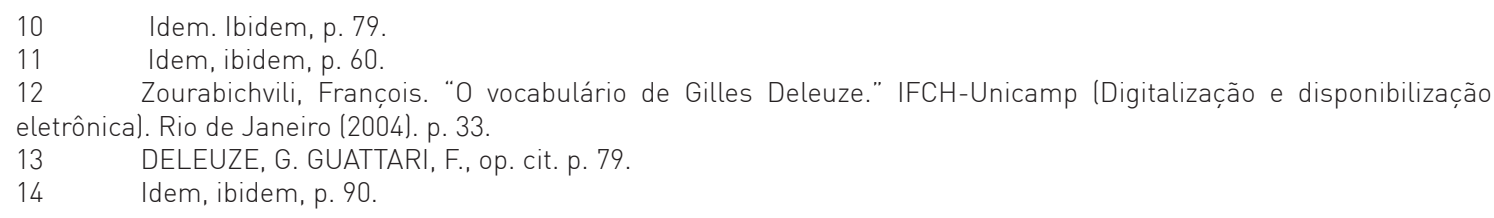


antes, um fazer, desse lugar, outro". 15

Nesse caminho, os artistas na educação formam bandos, compostos por alguns poucos adultos e muitas crianças e adolescentes que guardam juntos o segredo da potência que atravessa seus corpos em aula, que assim como um flashmob se dissipa e se dispersa ao toque do sinal. Mesmo assim, o bando é a formação, em geral, da máquina de guerra, que antes de tudo é afecto, não é organizado hierárquica e centralizadamente como a forma-Estado, ou seja, o professor não é o centro da aula.

A arte tem sempre o potencial de máquina de guerra, ela opera uma dupla resistência dentro da educação; em primeiro lugar, resiste à sua cooptação e despotencialização em formas estriadas, sedentárias, datadas, eurocêntricas e, em segundo, resiste ao próprio aparelho do Estado e sua pressão gravitacional. Não é tarefa pequena e não é gratuito que faltem tantos artistas na escola, é uma dupla batalha. Mas, é preciso manter-se otimista e imaginar, junto a Deleuze e Guattari, que "será possível que no momento em que já não existe, vencida pelo Estado, a máquina de guerra testemunhe ao máximo sua irrefutabilidade, enxameie em máquinas de pensar, de amar, de morrer, de criar, que dispõem de forças vivas ou revolucionárias suscetíveis de recolocar em questão o Estado triunfante". ${ }^{16}$ 15 FEIL, Gabriel Saussen. Nomadismo. In: AQUINO, J. G. CORAZZA, S. M. Abecedário: educação da diferença. São
Paulo: Papirus, 2009. p. 129.

16 Idem, ibidem. p. 18 


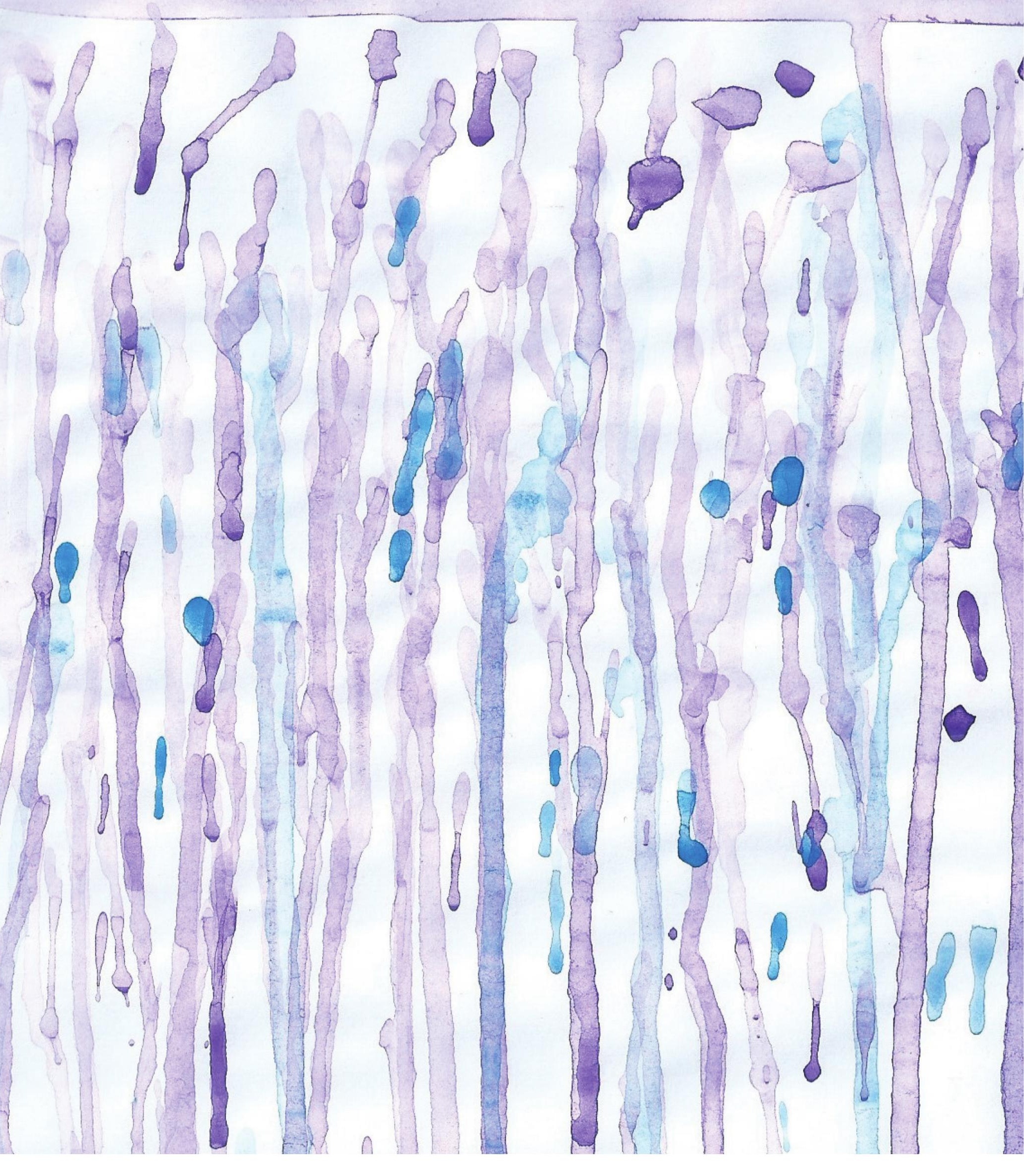




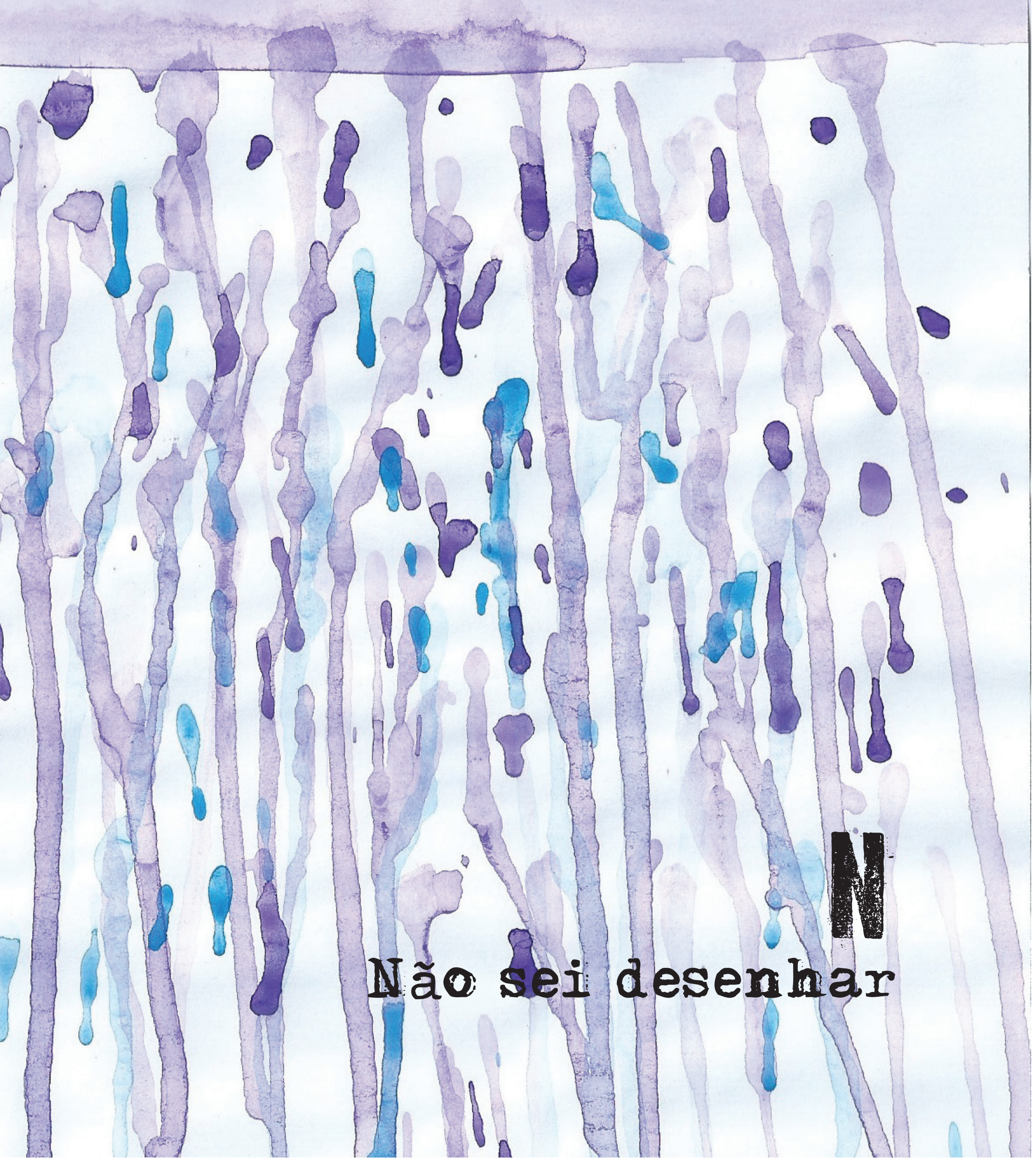



Diariamente o desenho é vilipendiado na boca dos alunos do Ensino Fundamental II e Médio. O que terá acontecido com ele? Por quê os alunos se recusam a desenhar?

Talvez parte desse desconforto tenha uma raiz histórica bastante forte, pois "ainda persistem no ensino da Arte, métodos e conteúdos que se originaram no século $X I X$, que se afirmaram educacionalmente no século $X X,{ }^{11}$ e permanecem ainda no século $X X I$, na forma de preconceito fundado na identificação entre arte e desenho presente na fala dos alunos dos diferentes níveis escolares que dou aula.

Há um saber em torno do desenho que, de alguma forma, fomenta as noções de arte emitidas, sobretudo, pela escola e pelo entendimento do papel da arte nesta instituição e que, assimiladas e reproduzidas pelos alunos, apontam para as linhas de enunciação da suposta verdade da arte naquele espaço.

Uma possível justificativa para essa conformidade entre desenho e arte talvez possa ser encontrada ainda no século XIX, com o recém-formado Reinado no Brasil e sua preocupação em fomentar o desenvolvimento de profissões. Neste momento, cursos livres de Desenho Técnico foram criados e houve a inclusão da disciplina Desenho no currículo do Seminário Episcopal de Olinda, que veio a substituir o antigo e extinto Colégio Real dos Jesuítas. ${ }^{2}$

Durante o início do século XX, a Escola Nacional de Belas-Artes (antiga Academia Imperial) exercia grande influência sobre o ensino da arte nas escolas primárias e secundárias, sendo que este também era resumido ao ensino do Desenho. Segundo Ana Mae Barbosa, um dos primeiros textos que reivindica o ensino do Desenho em todas as séries da educação básica é do escritor português André Rebouças, no qual advoga a importância do desenho na formação de todas as profissões: "se não é indispensável, é pelo menos, da maior utilidade". 3 Além disso, tanto Rebouças como Mário de Andrade argumentavam a favor do ensino do Desenho a partir de uma identificação do desenho com a escrita e a caligrafia como forma de vencer o preconceito que havia tanto em relação ao ensino da Arte como também à ideia de que desenho não tinha função ou que servia apenas a quem tinha talento. Rebouças faz clara distinção entre os dois tipos de desenho que dominaram o ensino da Arte no início do século $X X$ : "há o desenho de régua e de compasso e há desenho sem auxílio de instrumento nenhum. O primeiro está ao alcance de todos que não tem um defeito físico.(...) O segundo é mais difícil; só os privilegiados trazem esta faculdade inata, mas é muito raro que depois de dois ou três anos de prática de desenho não se consiga representar mais ou menos qualquer objeto sem auxílio da régua e compasso".4

Mas foi, Rui Barbosa, baseado em preceitos liberais na educação, o principal entusiasta do

\footnotetext{
1 BARBosA, Ana Mae. Arte-Educação no Brasil. São Paulo: Ed. Perspectiva, 1995. p.11

$2 \quad 0$ desenho - ou mesmo as artes em geral - pouco aparece nos documentos oficiais do período colonial até a expulsão dos jesuítas. Entretanto, anterior a este período, Ana Mae Babosa, aponta que o foco da reforma pombalina da Educação estava voltado ao ensino das ciências e que menção à arte foi feita com a criação da cadeira de desenho, especificamente Geometria, em 1771 em São Paulo.

3 Rebouças, André. IN: BARBOSA, Ana Mae. Arte-Educação no Brasil. p. 34

$4 \quad$ Idem, ididem. p. 37.
} 
ensino do Desenho na educação básica brasileira, especialmente porque enxergava no desenho uma possibilidade de progresso econômico, totalmente baseado no modelo norte-americano, o qual "já demonstrara enorme sucesso, através dos bem desenhados produtos americanos apresentados no Centenial Exhibition". ${ }^{5}$

Seu parecer sobre a educação primária privilegiava essencialmente o desenho com finalidades claras: "educar para o trabalho e também desenvolver valores estéticos e espirituais". ${ }^{6}$ Claramente, traz uma visão da arte cujos objetivos são morais, para uma educação de valores estéticos e éticos identificada, principalmente, com o desenho geométrico, cujo objetivo final era o progresso industrial.

Com a influência do positivismo nas teorias educacionais também no início do século $X X$, adveio a ideia de que ensinar arte (desenho) nas séries iniciais seria um importante instrumento de desenvolvimento do raciocínio estritamente ligado à geometria.

No entanto, um outro tom foi dado a importância do desenho quando foram trazidos ao Brasil técnicas antropométricas e testes psicológicos que se usavam do desenho para desvelar alguma suposta verdade sobre a criança. E, é especialmente nesse meandro, que a importância pedagógica da arte (desenho) que vigora ainda hoje nos discursos pedagógicos, parece se fundar. Ora, se o desenho revela o funcionamento da mente da criança, rapidamente "ele representa um meio de o professor descobrir as lacunas de cultura da criança, que de outra maneira, não descobriria". Tal frase também parece prenunciar uma primeira função da arte na escola - a de detectar e corrigir falhas culturais, ou seja, seria a arte um pressuposto suplementar de uma educação cultural do formando. A questão volta a aparecer em outros discursos e será tratada nos verbetes " $D$ "e "P".

As modalidades de desenho praticadas durante 1930 e 1970, segundo Fusari e Ferraz, eram as seguintes: o desenho de observação (representação do real), o desenho decorativo (ornamentos), o desenho geométrico (tendo esse grande importância no contexto da educação pública, pois era preparatório para algumas profissões) e o desenho pedagógico (ilustração de exemplos nas aulas). ${ }^{8}$

Com exceção do geométrico - que parece ter sido abolido e é desconhecido dos alunos e também das atribuições do professor de arte, - todos os outros desenhos mantém seu lugar de destaque na sala de aula, ao menos através do discurso dos alunos. Aqui, valeria a pergunta: Que noções de arte estão implicadas nesses usos do desenho? A resposta não parece complicada: arte como mimese, como habilidade de representar fielmente a realidade a partir de modelos a serem copiados.

Portanto, aqui podemos enxergar dois dos principais elementos trazidos nos discursos dos alunos sobre arte: um é a identificação da arte com desenho e o outro é a noção de

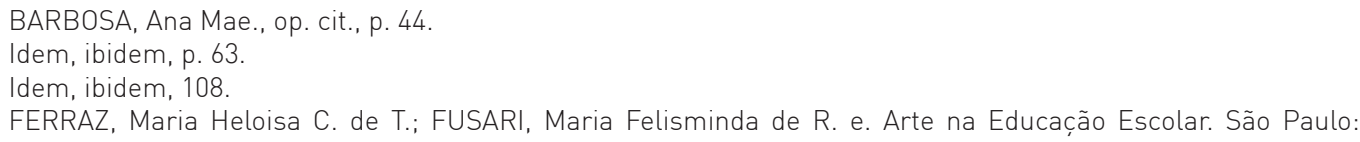


que "desenhar bem" é copiar com exatidão o que se vê. E além, podemos inferir que com a massificação dos discursos psicopedagogizantes na educação brasileira do século $X X$, desenho e arte passaram a figurar como estratégias para trabalhos pedagógicos desenvolvidos por outros profissionais ligados à educação que não o professor de arte, sejam pedagogos, sejam psicólogos. Tais práticas certamente contribuem para a difusão das ideias apresentadas, bem como para a banalização do desenho para além das aulas de arte.

Para Victor Lowenfeld9, autor bastante difundido no movimento da Escola-Nova no Brasil, a função da arte na educação é ser "um meio para se compreender o desenvolvimento individual em suas diferentes fases e como desenvolvimento da consciência estética e criadora do indivíduo". ${ }^{10}$ De forma que o desenho tornou-se uma atividade-coringa, tornando-se uma atividade com fins estranhos à própria criação artística, ficou assim utilitário. Desenha-se para representar graficamente a aquisição de conteúdo, desenha-se para figurar exemplos, desenhase quando o aluno terminou antes que os demais sua atividade. Desenha-se - e o pior, os alunos parecem ter sempre a sensação de que não sabem desenhar - pois o que está em jogo não parece ser o desenho como um tipo de pensamento e sim, novamente, como forma de expressão, mas sem disso se fazer uma boa discussão, que por exemplo tome a cabo a destituição da ditadura da verossimilhança à qual os alunos parecem estar tão presos.

Certamente há uma inclinação comunicativa própria ao desenho, a qual o pesquisador italiano Massironi chama de objetivo "comunicativo-informativo", o que o levou a analisar o desenho a partir dessa perspectiva comunicativa.

Assim, uma das funções do desenho é a ilustrativa - a mais comum tarefa do desenho, pois os desenhos são uma forma de rememorar histórias, fatos etc. Há também a função operativa - "de características peculiares, especialmente métricas e construtivas". ${ }^{11}$

Há ainda a função sinalética que envolve todo o desenho por ícones, como placas de trânsito, banheiros, stickmen, etc. E nesse caso, entram as casinhas estereotipadas - com chaminé, árvore com macieiras no jardim, etc. É interessante pensar sobre o processo do desenho com as próprias crianças e adolescentes para que eles possam ter clareza de que para além de uma habilidade ou falta dela, o que está em jogo, na maior parte da vezes, é um sistema de representação que pode ser dominado, e que em todos os casos vem precedido de uma narrativa evocada mentalmente ou oralizada.

O que precisamos é estar atentos aos gestos e às palavras, intervindo naquilo que barra a linha, bastante relacionada ao campo representacional mimético. Propor exercícios de desmantelamento dessa lógica que possam ampliar o sentido do desenho, para que as linhas possam percorrer caminhos desconhecidos para além da aula de arte, mas como mais uma ferramenta do pensamento.

\footnotetext{
9 LOWENFELD, Viktor. Desenvolvimento da capacidade criadora. São Paulo, Mestre Jou, 1970.

10 Idem, ibidem, p. 38

11 CELESTE, M. Um galo com quatro patas.In: DERDYK, Edith. Disegno. Desenho. Desígnio. São Paulo: Ed. Senac São Paulo, 2007. p. 273.
} 


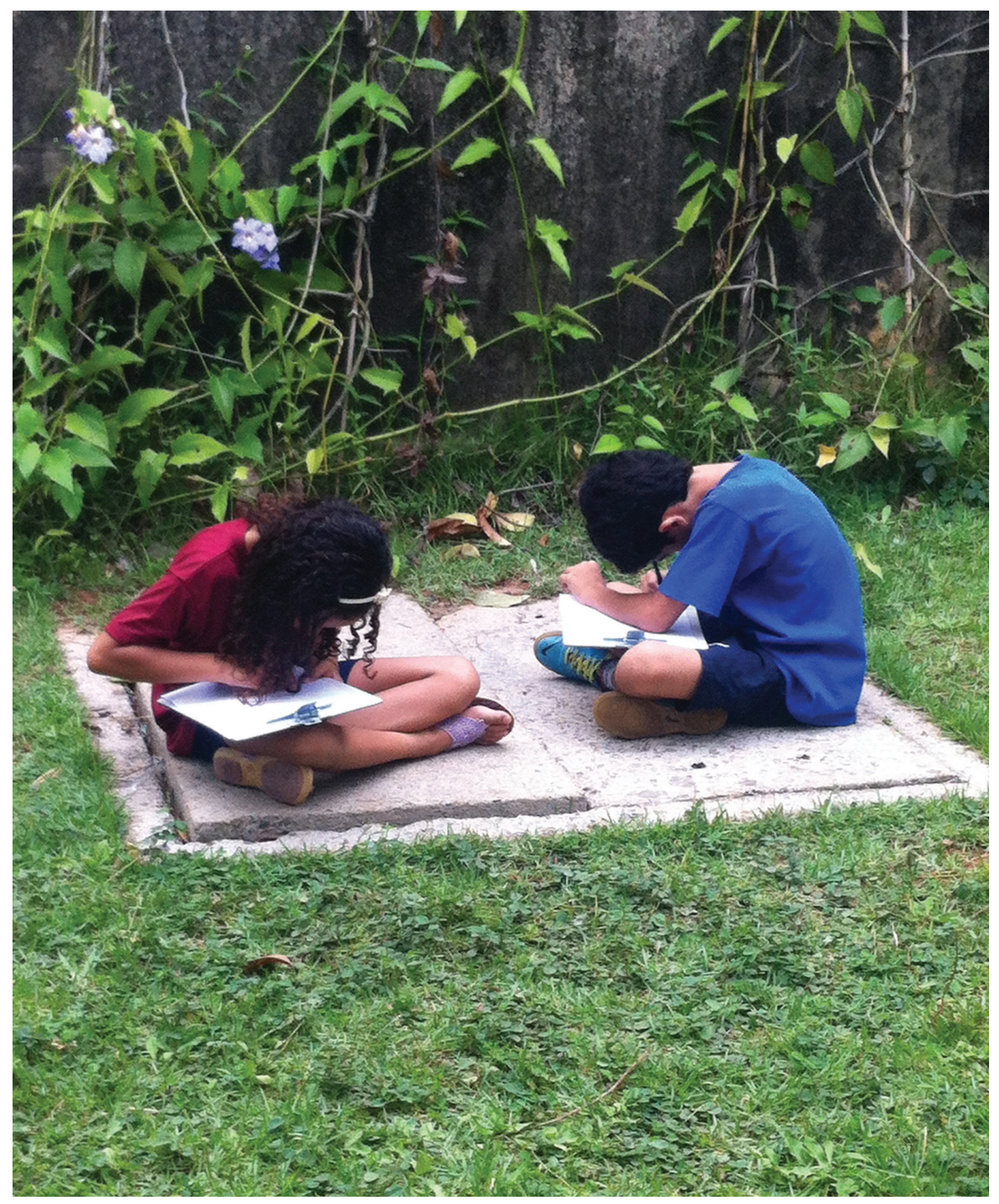

Exercícios de desenho de detalhe. Fonte; própria, 2014. 



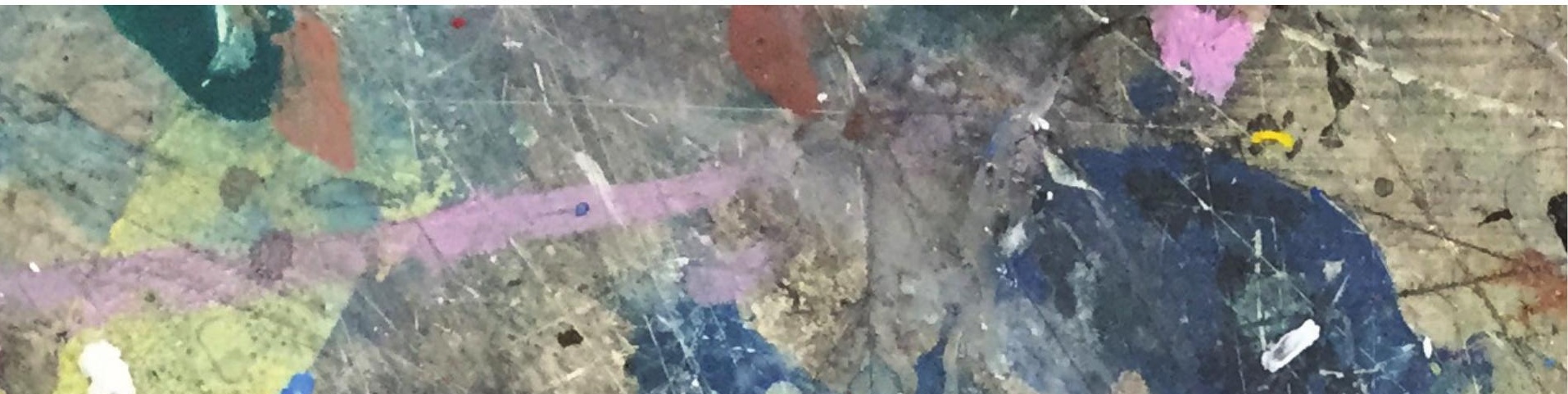

Y.: $9 y^{2}+1+3 y^{2}+y^{2}$

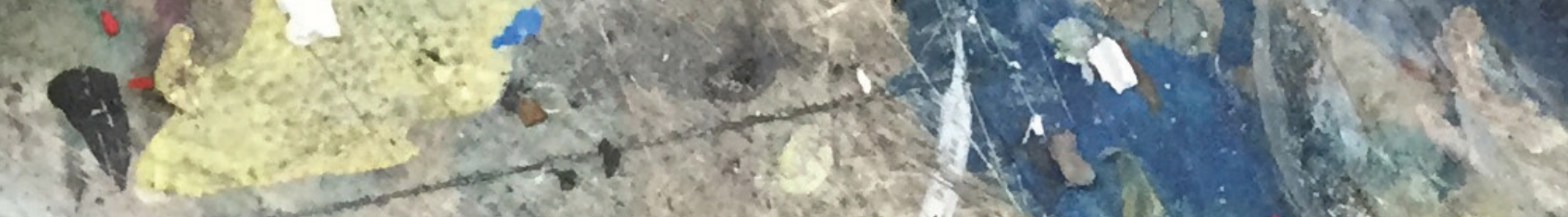
$x^{2} x^{2}$

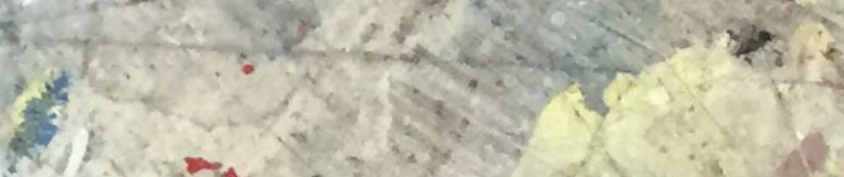

(4)

25

8

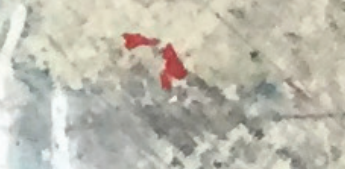

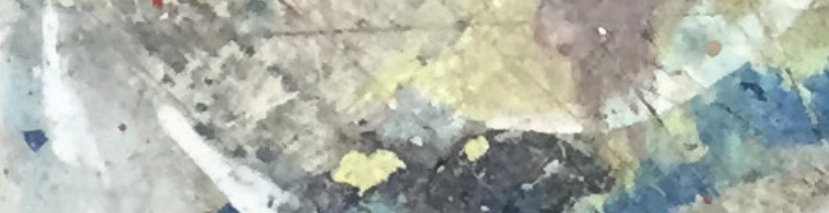

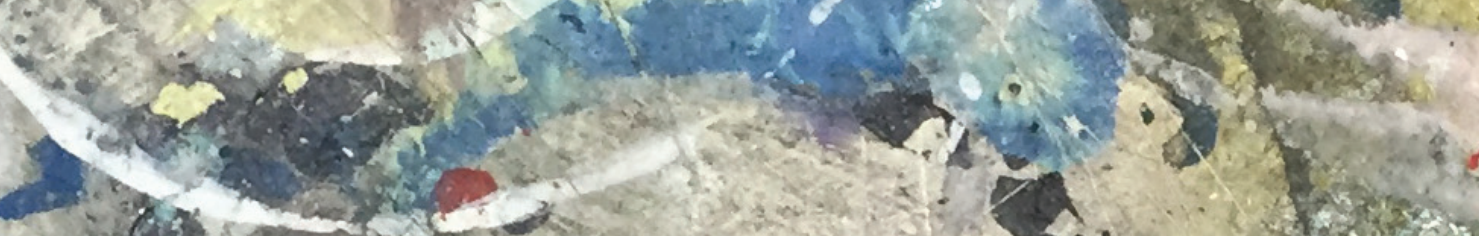

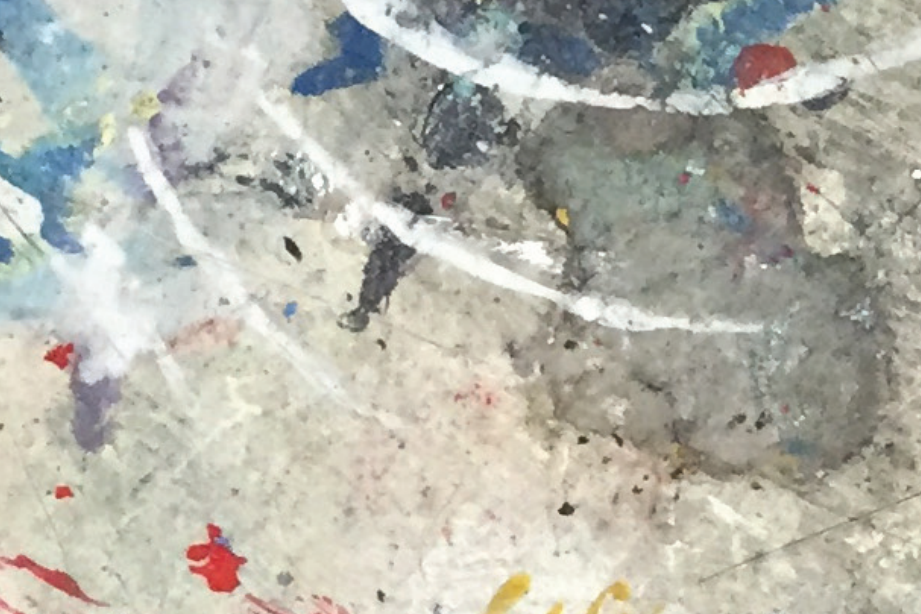

$\frac{2 .}{2}$

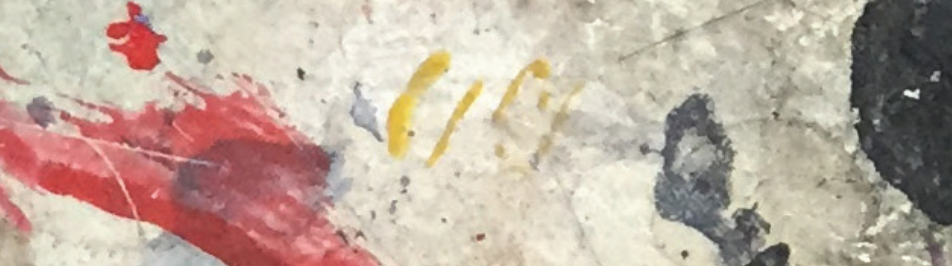

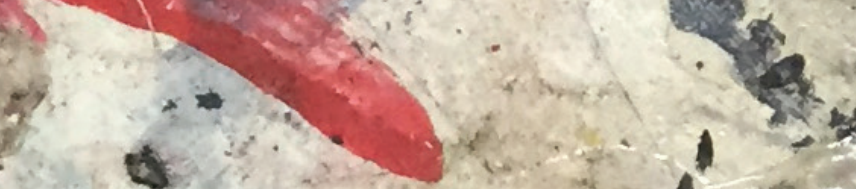

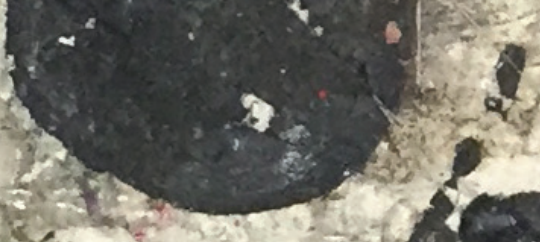

(1)

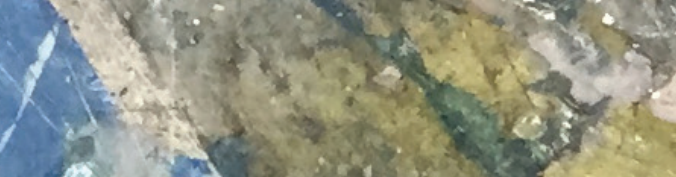
the $=x^{2}$ 


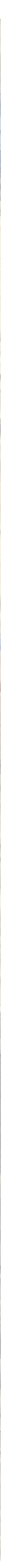




\section{O que vocês estão vendo?}

Esta é possivelmente a pergunta mais proferida em visitas educativas a instituições culturais e também na aula de arte quando o tema é leitura de imagem.

Desde o fim da década de 1970, com o objetivo de apreender e ler um mundo que se tornou imagético, vemos a passagem das artes plásticas para o domínio das artes visuais. Desde então, inúmeros são os textos que tratam da leitura de imagem, seja pelo viés estruturalista (ao qual se opõe a pesquisa dos estudos sobre a cultura visual), seja pelo construtivismo e as pesquisas de desenvolvimento estético. Figuram entre as principais referências os estudos de Robert Ott (1988), Michael Parsons (1992), Abigail Housen (1983), entre outros, bastante difundidos no Brasil.

Sob o cunho da apreciação de obras de arte (em instituições culturais) ou de suas reproduções (em sala de aula), a leitura de imagem entrou definitivamente na escola na década de 1980 e ganhou um espaço privilegiado na prática do ensino da arte por atender à necessidade de atrelar arte e conhecimento, para promover a cognição. Assim, a leitura de imagem tornou-se uma espécie de instrumentalização do olhar, com objetivos formalistas.

Para Analice Dutra Pillar, a leitura de uma obra de arte não pode ser feita desconsiderando o contexto histórico-cultural do artista e do espectador. Afinal, nosso olhar está comprometido com as nossas experiências. Além disso, a autora nos alerta para que não façamos leituras que aprisionem a obra de arte, criando significados fechados, como um mero exercício técnico, que acabam por reduzir a arte. Pillar argumenta que "compreender uma imagem implica olhar construtivamente a articulação de seus elementos, suas tonalidades, suas linhas e volumes. Enfim, apreciá-la".1

Não se trata de negar qualquer endereçamento científico que possa haver na arte, tampouco apartá-la do conhecimento. Contudo, é preciso manter-se alerta, pois, nesse tipo de abordagem, "em torno da arte formalista e datada em sua nomenclatura modernista (...), o termo 'apreciação' carrega conotações que remetem à obra enquanto produto submisso ao juízo estético tradicional (ser ou não ser arte) e algumas vezes às ordens mercadológicas". 20 efeito disso, na sala de aula, é possivelmente a canonização de algumas obras em detrimento de outras, especialmente de caráter "incontestável" de uma "boa arte" e uma sorte de trabalhos são deixados à margem visto o risco que representam para a própria caracterização da arte, por desestabilizar alguns paradigmas.

Entretanto, não seria a leitura de obra uma vilã da sala de aula ou da mediação educativa; é sabido que ela advoga muito bem a favor de um ensino da arte combativo a um "mero exercício escolar", parafraseando Ana Mae Barbosa. Mas, se arte não é o simplismo calcado na criatividade, tampouco é possível estruturá-la em um conjunto de regras a serem decifradas.

1 PILLAR, Analice D. (org.). A educação do olhar no ensino das artes. Porto Alegre: Mediação, $1999,$. p. 17. 2 ZORDAN, Paola. "Por poéticas no ensino da arte: uma sintomatologia”,. Revistarte. v. 1. n. 2, 2014, p. 5. Disponível em: http://<www.seer.ufrgs.br/gearte/article/view/47450/31271 $\rightarrow$. Acesso em 22/04/2015. p.5. 
A pergunta não precisaria ser reformulada se tivermos em vista que tipo de resposta queremos ouvir, ou seja, se "O que vocês estão vendo?" se referir ao embaralhamento proposital daquilo que se convenciona ou não arte. Trata-se de problematizar a própria ideia de gramática visual, haja visto que tanto a arte moderna quanto a contemporânea tratam desse tema, mas que, ao se fazer leitura de obra pela chave dos elementos formais apenas, pode empobrecer uma discussão de mais de um século de arte e com isso desfavorecer o entendimento da arte feita em nosso tempo.

A título de exemplo: de acordo com Lyotard, o pensador do período pós-moderno, uma leitura de obra que vá do modernismo até a arte atual não poderia ser feita sem se levar em conta o sistema de referenciação que constitui a arte pós-moderna como uma espécie de antemoderno, de modo que analisar o pós-moderno é pensar o modernismo em seu estado constante ou inicial. Ou, ainda, para o crítico de arte Ronaldo Brito, um dos principais sintomas do pós-moderno é o desejo incontornável de atravessar a arte moderna através de dois registros distintos: o primeiro seria como um trunfo do modernismo, em que a utopia de junção arte e vida teria logrado; o outro teria a ver com uma apatia melancólica de quem conhece a relatividade das rupturas e já não acredita mais no peso da história da arte. O primeiro caminho leva a uma produção que revela a vontade de reavaliar constantemente o passado, como se esse passado se colocasse "à nossa disposição para manipulações de toda espécie". ${ }^{3}$ Já no segundo caso, seja pela paródia ou pela omissão do passado, essa vertente do pós-modernismo vira-se para uma apreensão imediata da arte em sua mais acessível realidade - o mercado, sobre o qual parecem se instaurar as questões pulsantes da produção artística contemporânea.

Esse breve panorama tem a função de apresentar o cenário complexo que, desde pelo menos a modernidade, podemos identificar nos discursos da arte e que, de alguma maneira, não pode ser apartado da leitura de obras.

Mais uma vez, não é que a leitura na sala de aula devesse ser abolida, mas sim minimamente refletida, pois trata-se de uma prática que evidencia saberes sobre a arte - "quais são eles?" é a pergunta que não podemos perder de vista. Da maneira como é usualmente praticada, a leitura opera um tipo de canonização dos meios, entendida como uma espécie de construção formal, como se fosse impossível que existisse arte fora deles, e desconsiderando-se, com isso, parte da produção artística desde a modernidade.

São muitos os argumentos contra uma ideia de arte apenas retiniana; basta dar uma olhada na produção atual. Há também de se pensar, por exemplo, a partir de uma perspectiva deleuziana, como operar com arte se ela não comunica? "A obra de arte não tem nada a ver com a comunicação. A obra de arte não contém, estritamente, a mínima informação. Em compensação, existe uma afinidade fundamental entre a obra de arte e o ato de resistência".4

Além disso, a leitura de imagem não deveria levar em consideração que a arte pode não

3 BRITO, Ronaldo. "Pré, pós, quase ou anti?”. In: BRITO, Ronaldo; DE LIMA, Sueli. Experiência crítica. São Paulo: Cosac Naify, 2005,. p. 111

$4 \quad$ DELEUZE, Gilles. 0 ato de criação. Trad. José Marcos Macedo. Em: Folha de São Paulo, Caderno Mais!, 27 de junho de 1999.op. cit. 12 
estabelecer códigos? Apenas usá-los, pervertendo os usos convencionais ou fazendo citações, como Ronaldo Brito descreve a pós-modernidade?

$* * *$

Saindo do espectro da sala de aula, a leitura de imagem costuma ser o principal recurso utilizado nas visitas educativas em espaços culturais, contribuindo também para o enraizamento dessa prática e de certos discursos que dela decorrem, como acima explicitado. Porém, há uma nova discussão também em torno da mediação cultural que pretende propor uma inflexão nas posições definidas entre público, obra, mediador, artista e instituição. Algo como pensar a mediação para além da obra de arte.

Durante o período de 2007, no Paço das Artes, sob a coordenação do artista Jorge Menna Barreto, participei do grupo de educação coLABORativa, que consistia em uma equipe de educadores-artistas que tinham como premissa de trabalho a colaboração entre todos os envolvidos em uma visita educativa a partir da ideia de uma mediação como construção, em contraposição a uma suposta fruição gratuita e espontânea, fruto de uma lacuna por parte do público a ser sanada.

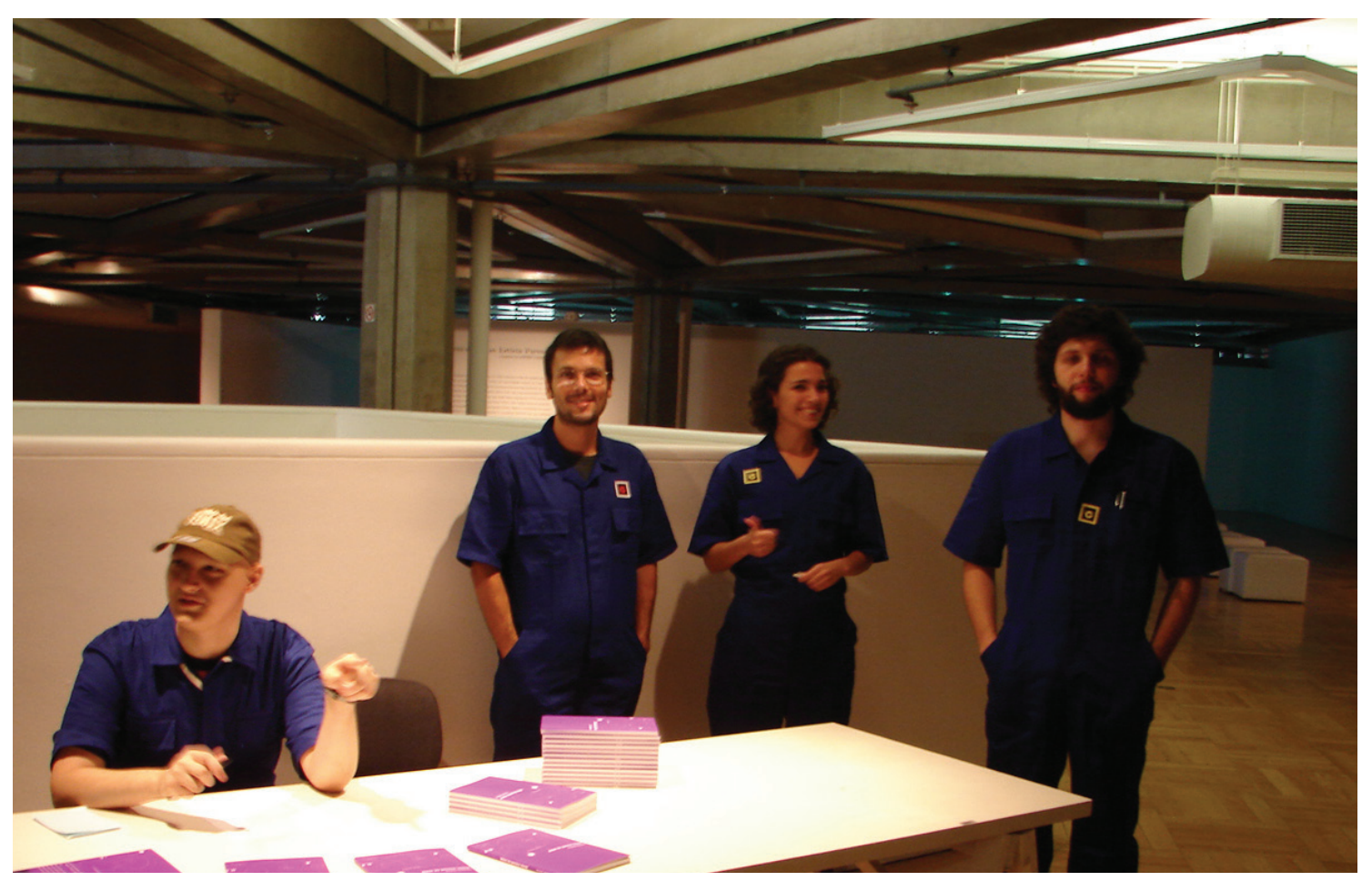

Artistas-educadores: Daniel Argento, Jorge Menna Barreto, Kelly Sabino e Diogo de Moraes no Paço da Artes em evento com Ricardo Basbaum e o seu trabalho NBP. 
Assim, todo o trabalho (labor) tinha em vista um pensamento da experiência estética da relação com a obra de arte, num espaço institucional como aquele, como um trabalho, uma construção. Longe da isenção pretendida por muitos tipos de visitas mediadas, nossa atividade era entendida como uma prática artística-educativa, investigando a ação educativa como um espaço de invenção e colaboração que excedia a visita educativa pautada na obra de arte, buscando criar novos estados de mediação.

No bojo dessa discussão sobre uma mediação para além da obra, encontramos trabalhos contemporâneos de educação em instituições culturais, que apontam para uma espécie de redefinição do estatuto da mediação, questionando-o quanto ao seu formato e conteúdos. E é na esteira dessa redefinição dos papéis, não mais estáveis, entre artista, curador, público, obra e vida, que seria interessante pensar a leitura de arte, contribuindo para a experimentação da principal potência da mediação - o encontro, com o próprio do processo criativo -, a intencionalidade esculpida pelo imprevisível.

Essa interface entre educação e arte dentro de uma instituição cultural, por óbvio, é diferente daquela relação entre esses termos na escola; no entanto, como eu que já estive intensamente nesses dois papéis, gostaria de propor que uma transposição pudesse ser ensaiada aqui, e que pudéssemos, ao pensar o mediador, evocar também a figura do professor.

É sabido que a mediação cultural tem ganhado um espaço privilegiado na economia da arte (instituições culturais, museus, galerias etc.), ora figurando como uma estratégia de marketing e assumindo um papel assistencialista (giro de catraca, número de visitantes,etc.), ora constituindo um projeto pedagógico sério.

Em qualquer um dos casos, as instituições culturais têm cada vez mais abarcado o público escolar, incluindo massivamente alunos da rede estadual de ensino através do programa Cultura é Currículo, desenvolvido pelo Fundo para o Desenvolvimento da Educação, com a justificativa da cultura como "parte do patrimônio das sociedades," e tendo a escola a função de "fazer com que seus alunos reconheçam esses locais, como também que a eles tenham acesso". 5 Tudo em nome de uma formação estética e cultural mais plural.

Assim, vemos um inflacionamento das práticas educativas nas instituições culturais - com exposições cada vez mais cheias. No entanto, seria oportuno refletir sobre a mediação cultural e o quê há de educação circula por ali. Carmen Mörsch, pesquisadora do projeto educativo da Documenta 12, em oficina ministrada em São Paulo, ${ }^{6}$ nos apresenta algumas funções, por ela formuladas, sobre as atribuições da mediação em instituições culturais:

Função afirmativa: a mais difundida no museu; instrumento do museu para sua autoafirmação como máquina da verdade, narradora de grandes histórias; expressa nas visitas guiadas tradicionais, em que apenas se apresenta o texto curatorial aos visitantes; postura de que o

5 Apresentação do projeto Cultura é Currículo no site: <http://culturaecurriculo.fde.sp.gov.br/Lugares\%20 de\%20Aprender/lugares_aprender.aspx?projeto $=2 \rightarrow$. Acesso em 13/04/2015.

6 Oficina realizada em agosto de 2008 no Instituto Goethe - SP. 
público do museu é a clientela reservada dos profissionais ou especialistas.

Função reprodutiva: preocupada com a formação do público de amanhã, com a manutenção do museu, por exemplo, daqui a vinte anos, diante da diminuição de seu público tradicional e tendo que concorrer com as sempre novas ofertas de lazer.

Função desconstrutiva: questiona o museu em si - o que ocorre de vez em quando em muitas instituições; reflete sobre o museu em suas funções, por exemplo, a de selecionar, para lembrar as histórias que são caladas pelas histórias contadas; os ritos civilizatórios que ele processa; empreendida também por artistas, em suas intervenções com ou para o público, como um comentário crítico do que ocorre.

Função transformativa: mais difícil de ser efetivada; por um lado, perspectiva compartilhada pela instituição, de que o trabalho da mediação mude e melhore a vida das pessoas, as condições sociais, e combata a desigualdade; por outro, tentativa de redefinir ou ampliar as funções do museu. Vale ressaltar que essas funções não funcionam cronologicamente; elas estão em entrecruzamentos em cada visita ou situação, embora somente as duas primeiras apareçam sempre. nem devemos pensá-las de forma maniqueísta, embora haja tensão e conflito entre elas. Por isso, na Documenta, era fundamental que os mediadores se perguntassem onde queriam chegar e que trabalho desejavam fazer. ${ }^{7}$

Em uma análise geral e pouco aprofundada, podemos perceber que as funções mais usuais nas nossas instituições são a afirmativa e a reprodutiva, e, apesar de responderem em parte às questões que colocamos e de fornecerem substrato para aquecer a discussão, tais questões postulam um novo problema para a mediação: ao operar, tanto na função afirmativa quanto na reprodutiva, de que forma a mediação encara seu público?

Arrisco uma hipótese: a mediação cultural tem operado numa lógica que é a da falta. 0 público não entende ou não sabe ver arte, e a mediação, por sua vez, propõe o suplemento como remédio através da oferta de visitas de todos os tipos (fast, uma única obra, com curador, com artista, com educador, especial, etc.), operando de forma como se o museu ou instituição fossem provedores de uma educação artística ou estética defasada na escola e/ou na vida, e prestando serviços que preencham esta falta na visita. Acontece então um trabalho quase messiânico: uma condução do público até a arte, descrita em diferentes livros de arte-educação como um processo de conquista e sedução do público.

Nos seria oportuno perguntar: essa falta é sanada? Ou, então: pode ser sanada?, levando-se em conta que é através desse discurso que a instituição e o próprio setor educativo se afirmam. Para ilustrar as pontuações apresentadas, a figura do mediador como ponte pode ser bastante conveniente, inclusive, bastante difundida por um certo saber da prática da mediação, no qual, a figura do mediador ajuda o público a alcançar a obra a partir de um esquema de perguntas e respostas, que se pretende dialógico: 0 que vocês veem aqui? Qual é a cor desse quadro? E daí

$7 \quad$ HONORATO, Cayo. Status e funcões da mediação educacional da arte - relato sobre palestra, debate e oficina com Carmen Mörsch. Em http://<www.forumpermanente.org/event_pres/exposicoes/documenta-12-1/relato-sobrepalestra-debate-e-oficina-com-carmen-morsch $\rightarrow$. Acesso em 08/03/2015. 
por diante. No entanto, sempre me pergunto: por que os mediadores nos fazem perguntas que já sabem e que já conhecemos a reposta? Essa pseudodialogia não é potencializadora, pois já tem respostas prontas, o que acaba por contribuir para um tipo de infantilização do público. Como bem apresenta Pierangelo Maset, artista/educador/curador italiano, preocupado em atualizar funções e discursos da Arte-educação, para ele, a "a arte-educação sempre teve o problema de operar com estruturas e metodologias fixas que não têm muito em comum com a improbabilidade da arte. o impulso real da arte - a livre brincadeira da forma e da imaginação - sofre sob o regime das operações técnicas da arte-educação. Aqui, a arte-educação é um caminho distante da arte. Ela usa o glamoroso rótulo 'arte' para propósitos pedagógicos que são muito mais centrais do que o conteúdo artístico, mostrando pouca apreciação por uma mentalidade artística". ${ }^{8}$

Ora, se a mediação trata de aliar à arte um tipo de educação, como diz Maset, pode-se dizer que se trata de um tipo de educação muito mais procedimental do que experimental, a partir de metodologias e instrumentalização do olhar.

Em 2011, na ocasião do $1^{\circ}$ Edital de Mediação em Arte do Centro Cultural São Paulo, fui contemplada com o projeto Linhas de encontro... atrás do desejo e da criação. ${ }^{9}$ Esse trabalho visava pensar a mediação como trabalho de arte, como uma maneira de pesquisar novos modos de relação entre pessoas e arte. Ao invés de impor uma forma de relação entre arte e público, de ter premeditado o que fazer, operou-se com a ideia de mediação como encontro, como Acontecimento. Para tanto, vali-me de três linhas de atuação, pensando a mediação como prática artística:

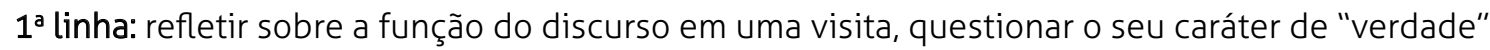
alimentado tanto pela fala de "especialista" do mediador, da instituição, quanto do visitante. Interessava-me ali tencionar discursos e propor situações de mediação na exposição que desconfigurassem os papéis instituídos nessa relação: público - mediador - obra. A ação se chamou $\mathrm{E}$ se..., pois toda vez que ela acontecia os mediadores vestiam uma camiseta escrita na parte da frente "E se..". e, na de trás, "For tudo mentira?".

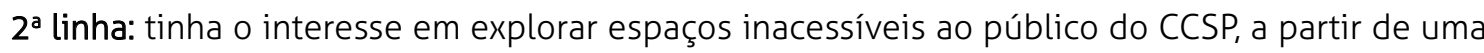
visita que tornaria público espaços que não eram públicos e que, ao mesmo tempo, saísse de um tipo de visita "técnica" e se transformasse em uma experiência poética e criadora para os visitantes. Dessa linha surgiu a ação Lado B do CCSP, na qual convidávamos o público espontâneo a uma visita pelo porão do CCSP, pela gráfica, camarins e culminava num palco escuro, no qual o visitante tomava o lugar do artista e produziu diversos acontecimentos.

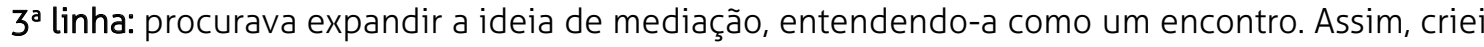
a ação "Troco Simpatia", uma barraca de camelô itinerante pelo CCSP de troca de simpatia (em

8 MASET, Pierangelo. "MASET, Pierangelo. Between education and participation: Aesthetic operations". Artigo publicado na revista Engage n.o. 20,. 2009. Disponível em: http:// $\leftarrow$ www.engage.org/downloads/215025048_EJ_20_P. Maset.pdf $\rightarrow$. Acesso em 15/07/2014. (trad. aut.).

$9 \quad 0$ vídeo Linhas de encontro... encontra-se disponível no endereço: $\leftarrow$ http://temporalfilmes.com/Linhas-deEncontro $\rightarrow$. Acesso em 06/03/2015. 
todas as acepções possíveis). A barraca foi o dispositivo montado para encontrar-me com as pessoas que circulavam pelo CCSP.

O trabalho foi desenvolvido durante seis meses e estabeleceu relações inusitadas com o público espontâneo daquele aparelho cultural, alcançando um dos principais objetivos do projeto, que era romper com discursos majoritários do mediador como detentor da verdade, com o engrandecimento de obras em detrimento de pessoas e encontros. Com a $2^{a}$ linha, alcançamos um desmanche da visita mediada, pois uma experiência que inicialmente era reconhecida como uma "visita educativa" e que ao longo se transformava em uma visita "poética" (como um dos participantes definiu). Desmanchávamos a ideia de visita passiva ao convocar o público a deixar seu gesto numa parede do porão do CCSP que ficará ali indeterminadamente. Desfazíamos a ideia de visita "informativa" quando inseríamos Hamlet e consignas na visita: "Fale as minhas falas tal como eu as pronunciei" ou "Adeque a ação a palavra e a palavra a ação". ${ }^{10} \mathrm{O}$ desfecho da visita propunha ao público tomar a parte do artista e ocupar o palco do seu lado de dentro e não como espectador. A proposta de atuação no palco era feita de acordo como que sentíamos do grupo; por vezes, os convocávamos a se mexer, dançar, cantar no espaço, e, em outras, o silêncio, a escuridão e as coxias deixavam o grupo mais vontade para agir. A mediação acontecia em plena escuta de cada grupo. Não nos interessava fazer uma visita técnica ao porão. Nosso interesse era criar nesse espaço-tempo um encontro, uma tensão, um acontecimento. Essa combinação de visita ao subterrâneo "proibido" com inserções poéticas possibilitou em cada visita a criação de ambientes íntimos com pessoas que jamais haviam se visto antes. As pessoas do grupo (sempre público espontâneo) pareciam, ao final da visita, ser amigas, e, por vezes, continuavam conversando. Havia uma cumplicidade naquele encontro. Talvez pela dramaturgia, talvez pelo compartilhamento de uma experiência totalmente diferente do que se é esperado de uma visita.

O projeto trouxe uma possibilidade de expandir a noção de mediação como reprodução de discursos e manutenção de "verdades", colocando-a num plano de atuação contaminado por interesses comuns a práticas artísticas contemporâneas interessadas em intervenções na qualidade das relações e experiências entre obra/artista/sujeito, desfazendo muitas vezes esses limites, pois a "relação sujeito - objeto está ligada à presença desta rede de relações como um campo de experiência, no qual é exigida uma imersão no processo de proximidade máxima com o objeto como condição mesma da experiência: tanto sujeito como objeto serão constituídos a partir da intensidade do processo experimentado, resultado não-linear do esforço inventivo". ${ }^{11}$

Finalmente, essa ação, assim como outras, apontam para uma tomada de posição política em relação à mediação, em busca de um lugar não-burocrático, professoral, pastoral, especialista, etc. Seja em instituições culturais, seja na escola, o lugar da arte deve ser o da inconformidade e da resistência.

10 SHAKESPEARE, W. Hamlet. Ato III Cena 2. Disponível em: $<$ http://atragediadehamlet.blogspot.com.br/2011/03/ ato-iii-cena-2.html $\rightarrow$. Acesso em 10/04/2015.

11 BASBAUM, Ricardo. Além da pureza visual. Porto Alegre: Zouk. 2007. p. 19-20. 


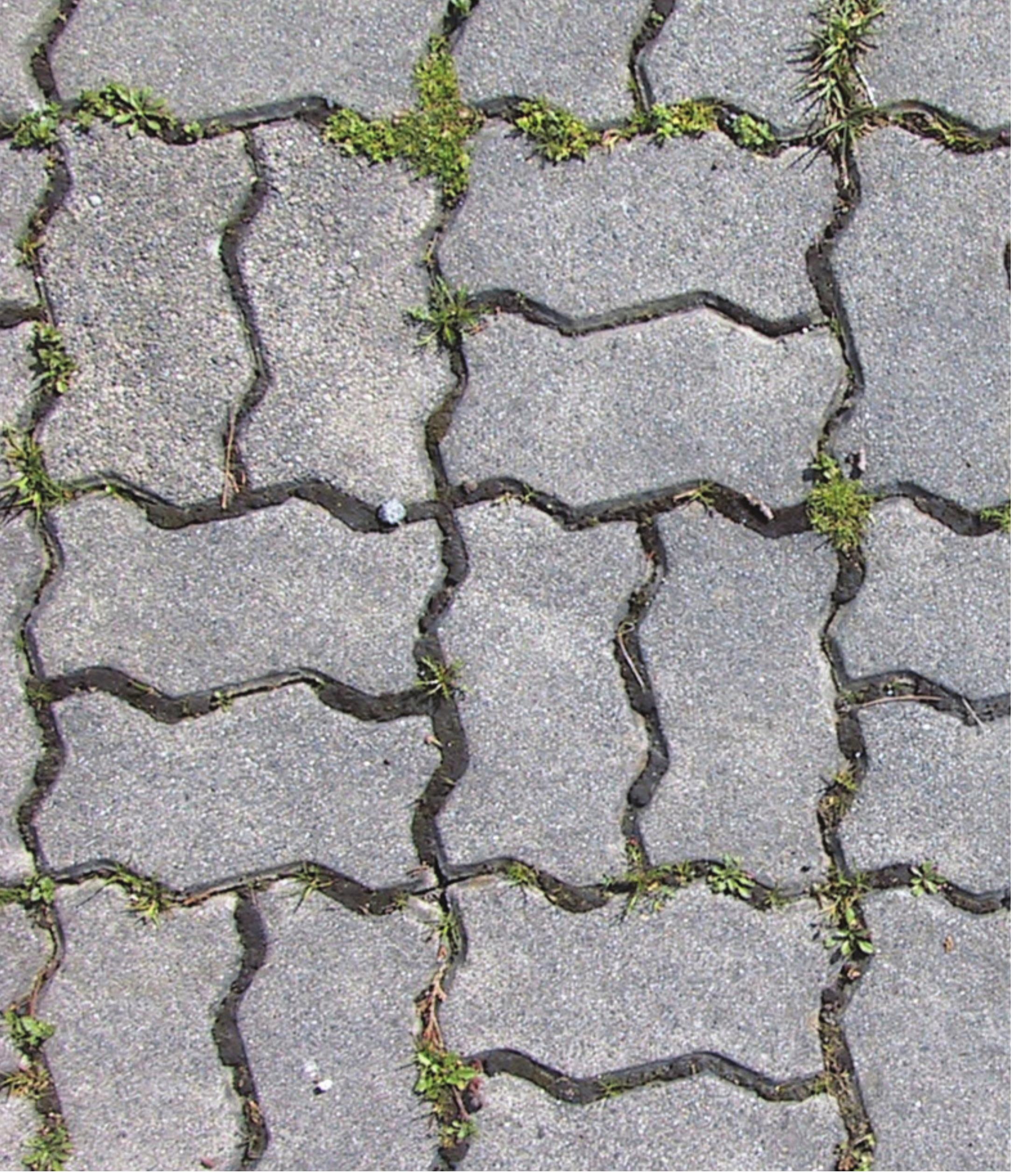



Como é sabido desde pelo menos Marcel Duchamp, os limites que determinavam o que é ou não arte e cada umas das suas linguagens está bastante indeterminado. Disso parece derivar a dificuldade em tratar do contexto contemporâneo artístico em sala de aula. Para além disso, tal perspectiva contemporânea da arte nos possibilita assumir que o imbricamento entre esta e a vida está em constante tensionamento, oferecendo-nos, como substratos de trabalho docente em arte, a vida como objeto e suas ramificações como possibilidades de trabalho. Contudo, é preciso algum parâmetro. Quais são os parâmetros? De que forma os Parâmetros Curriculares Nacionais entendem a arte? Quais noções estão ali colocadas?

Sirene.

Pátio, corredores, salas de aula, banheiros, todos somos invadidos momentamente por esse ruído. Frio que percorre toda a espinha, um espaço-tempo de trinta segundos de angústias, ansiedades, aceleração, passo lento: uma inundação em que vivo intensa até hoje, após cinco anos dessa mesma experiência. Devo entrar na sala com alguma proposta concreta e outras várias propostas na manga. Aflita, procuro nos documentos algum apoio, lastros que norteiem isso que será para mim a docência. Encontro mais perguntas: "Que tipo de conhecimento caracteriza a arte?", "Qual a contribuição específica que a arte traz para a educação do ser humano?," "Como as contribuições da arte podem ser significativas e vivas dentro da escola?", "Como se aprende a criar, experimentar e entender a arte?" e, por fim, "Oual a função do professor nesse processo?". ${ }^{1}$

Trata-se de questões de suma importância, uma vez que são os Parâmetros Curriculares Nacionais que norteiam a prática docente com o objetivo prescrito de fornecer "uma compreensão do significado da arte na educação, explicitando conteúdos, objetivos e especificidades, tanto no que se refere ao ensino e à aprendizagem, quanto no que se refere à arte como manifestação humana".2 Ou seja, os parâmetros não somente pretendem propor um sentido da arte na educação enquanto metodologia (como se ensina e se aprende arte), como oferecem também substratos para constituir um conceito de arte dentro da educação.

O documento é dividido em duas partes: a primeira é destinada à fundamentação e à contextualização do ensino de arte e, a segunda, à descrição das especificidades do ensino de cada uma das quatro linguagens artísticas abrangidas: artes visuais, teatro, música e dança.

Ainda que $o$ interesse com essa pesquisa esteja mais nas potencialidades e nos procedimentos artísticos - tentando escapar às armadilhas oferecidas pelas definições, por entender que "as definições da arte e as soluções que dizem "por que o homem faz arte", "no que constitui a arte", "qual teor da arte", talvez não sejam importantes para pensarmos qual o sentido da arte no campo da Educação,"3 - é necessária uma leitura mais atenta dos Parâmetros,

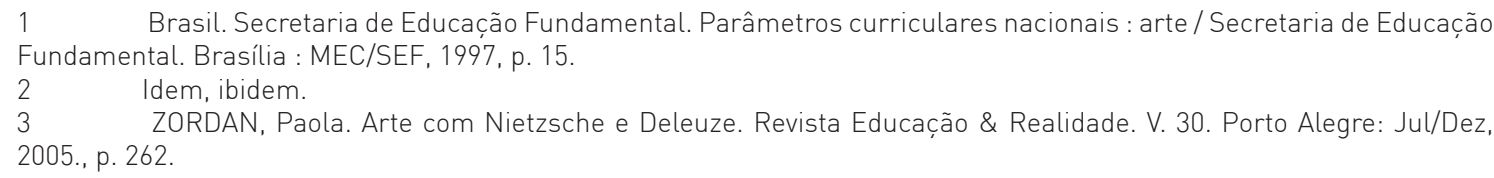

ZORDAN, Paola. Arte com Nietzsche e Deleuze. Revista Educação \& Realidade. V. 30. Porto Alegre: Jul/Dez, 
pois é justamente ali onde se encontram enunciados, definições e conceitos que colaboram para a constituição de uma cultura escolar em torno da arte. Para buscar encontrar as noções de arte que fazem circular este documento, esta análise se restringirá a, apenas, a primeira parte dos Parâmetros, uma vez que ela, a exemplo de Zordan, "foi elaborada para que o professor possa conhecer a área na sua contextualização histórica e ter contato com os conceitos relativos à natureza do conhecimento artístico".4

A discussão não é simples e merece ser tomada com cuidado, pois, obviamente, não se pretende dizer o contrário do que os Parâmetros Curriculares Nacionais dizem. Ao que parece, eles têm a preocupação de subsidiar a tomada de consciência dos professores, em relação ao conhecimento artístico. Pois, segundo os próprios Parâmetros,

Sem uma consciência clara de sua função e sem uma fundamentação consistente de arte como área de conhecimento com conteúdos específicos, os professores não conseguem formular um quadro de referências conceituais e metodológicas para alicerçar sua ação pedagógica; não há material adequado para as aulas práticas, nem material didático de qualidade para dar suporte às aulas teóricas. ${ }^{5}$

Em contraposição à tomada de consciência por parte dos professores, haveria uma inadequação das especificidades do conhecimento artístico que beiraria o que pregava a livre expressão e, consequentemente, anunciaria uma ineficácia dos próprios parâmetros.

De partida, é bastante notável a preponderância das artes visuais nas diretrizes gerais dos Parâmetros, tanto do Ensino Fundamental I quanto do Il. As propostas das outras três linguagens estão organizadas pelos eixos da Proposta Triangular - cujo objetivo seria "por premissa básica a integração do fazer artístico, a apreciação da obra de arte e sua contextualização histórica"6 _ ainda que sem se remeterem a eles diretamente.

Outro aspecto não problematizado é a crença no caráter educativo da arte. Tal crença, conforme vamos apresentar a seguir, é assegurada por uma noção de arte, ainda que não seja apresentada desse modo. Ao contrário de restringir-se a um conceito de arte, o documento vai constituindo - de forma dispersa, ora por sintagmas, citações esparsas ou mesmo afirmações peremptórias, e, principalmente, sem a devida contextualização ou evidenciação da base teórica para tal - o lugar da arte na educação.

Talvez uma justificativa para a hegemonia das Artes Visuais no documento se dê pelo fato de que as discussões pedagógicas - e políticas -, do ensino da arte, estivessem fundamentadas pelas artes visuais e pela Proposta Triangular.

Tanto no documento dos dois primeiros ciclos, quanto no $3^{\circ}$ e $4^{\circ}$ ciclos do Ensino Fundamental, apesar de alterações no texto, mas não na concepção, o "conjunto de conteúdos

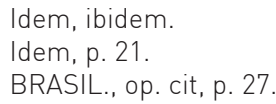


está articulado dentro do contexto de ensino e aprendizagem em três eixos norteadores: a produção, a fruição e a reflexão"?

Através da leitura deste documento, percebemos o terreno movediço que é propor definições no campo da arte; vemos que no texto elas são feitas a partir de frases de artistas retiradas dos seus respectivos contextos históricos, como "Quero pintar em verde e vermelho as paixões humanas", ${ }^{8}$ para tentar dar conta dos processos envolvidos na criação artística sem fechar em um conceito delimitador.

Trata-se de frases que funcionam como metonímias correspondentes a uma noção de arte que, ao longo do documento, não se anuncia; isso acontece a partir de frases como esta, e que nos falam de pré-concepções artísticas identificadas ao ideário romântico e sua ênfase nos aspectos emocionais do artista.

Tal visão romântica da arte, cujas origens se encontram no Romantismo do final do século XVIII, parece conduzir - ainda que sem ser anunciada - à primeira parte do documento em inúmeras passagens como a seguinte:

o motor que organiza esse conjunto [formal] é a sensibilidade: a emoção (emovere quer dizer o que se move) desencadeia o dinamismo criador do artista. A emoção que provoca o impacto no apreciador faz ressoar, dentro dele, o movimento que desencadeia novas combinações significativas entre as suas imagens internas em contato com as imagens da obra de arte. ${ }^{9}$

O Romantismo caracteriza-se pelo predomínio do sentimento. É possível encontrar respaldo teórico em diversos autores e filósofos, como, por exemplo, Rousseau, para quem a razão estaria subordinada ao sentimento, ou, então, ao culto ao gênio de Kant, que nos Parâmetros Curriculares Nacionais aparece com a exacerbada ênfase dada à personalidade do artista e seu processo criador. Percebe-se que

há uma supervalorização da emoção, com ênfase na sensibilidade inventiva, sem que, no entanto, a maior parte das noções utilizadas seja explicitada. Várias categorias conceituais vinculadas a uma visão da arte como emoção são empregadas neste documento. ${ }^{10}$

Há ainda no documento relativo aos primeiros ciclos do ensino fundamental uma associação direta entre a arte que se faz na escola e uma noção de arte absoluta - "a obra de

\footnotetext{
$7 \quad$ Idem, p. 41.

BRASIL., op. cit, p. 30

BRASIL, op. cit. p. 40 10 ALVES, E. PENNA, M. "Marcas do Romantismo: os impasses da fundamentação dos PCN-Arte". In: É este o
ensino de arte que queremos? Uma análise das propostas dos Parâmetros Curriculares Nacionais. João Pessoa: Editora Universitária, 2001.
} 
arte situa-se no ponto de encontro entre o particular e o universal"11 - ou afirma-se, ainda, que a partir do ensino da arte é possível desvelar uma verdade sobre a arte sem oferecer qualquer vinculação com práticas artísticas, em particular, ou mesmo de forma geral.

Assim, ao definir arte para que os professores de arte constituam seus planos curriculares com embasamento teórico que o documento anuncia trazer, o mesmo não apresenta qualquer problematização conceitual do termo, tampouco assume a adoção de alguma filiação teórica. Ao que parece, elucidar, para o entendimento do documento, a existência de uma arte essencial e universal é inquestionável.

Mais adiante na leitura aparecem afirmações como sintagmas, a partir das quais se desenvolve a conceituação da arte, que está em todos os casos atrelada à sua função educativa: para além de tais afirmações que tentam conceituar o que é arte, percebe-se ali, uma inclinação que insiste em reiterar a importância da arte na educação. Assim, parece ser preciso convencer o leitor do documento de que a arte é assunto sério - é conhecimento.

No entanto, a caracterização desse conhecimento que se constitui com o objetivo de organizar a área de arte na educação a fim de que a livre expressão, por exemplo, seja apenas um dado histórico, é contradito pela própria argumentação que sustenta o que o documento assinala como processo criador, conhecimento artístico, todos eles, como apresentado anteriormente, frutos de um ideário romântico - cuja tônica se encontra na genialidade e na espontaneidade de criação do gênio. Ou seja, os Parâmetros parecem querer sanar o problema do laissez-faire usando-o como antídoto.

É claro que isso não se dá de forma direta, o que vemos é que, ao invés de fomentar a não intervenção na criatividade dos alunos - o que não justificaria o propósito de sistematizar a arte como conhecimento -, ressalta-se, por exemplo, a criação pela mistificação da figura do artista, traço principal do Romantismo, como podemos ver ressaltado no seguinte excerto:

No processo de conhecimento artístico, do qual faz parte a apreciação estética, o canal privilegiado de compreensão é a qualidade da experiência sensível da percepção. Diante de uma obra de arte, habilidades de percepção, intuição, raciocínio e imaginação atuam tanto no artista quanto no espectador. Mas é inicialmente pelo canal da sensibilidade que se estabelece o contato entre a pessoa do artista e a do espectador, mediado pela percepção estética da obra de arte". ${ }^{12}$

Ou seja, o interesse não está na obra e sim na comunicação que ela propicia entre o artista e o aluno. É sabido que uma obra pode ter diversas leituras e que o espectador tem grande importância nelas, pois "estabelece o contato entre a obra de arte e o mundo exterior, decifrando e interpretando suas qualidades intrínsecas e, desta forma, acrescenta sua 
contribuição ao ato criador". ${ }^{13}$ Porém, os Parâmetros Curriculares Nacionais parecem dizer que o objetivo do conhecimento artístico está na sensibilidade estética, sem apresentar o que isso significaria e sem considerar que "a significação de uma manifestação artística é o produto de um conjunto de fatores, entre os quais o próprio modo de organização e funcionamento - histórica e culturalmente situado - da linguagem artística". ${ }^{14}$

Ao longo dessa primeira parte do documento, notadamente, são feitas investidas na consolidação/convencimento da importância do ensino da arte: "o ensino de Arte é área de conhecimento com conteúdos específicos e deve ser consolidada como parte constitutiva dos currículos escolares". ${ }^{15}$

Curiosamente, ao contrário do que ocorre nas demais disciplinas, os parâmetros de arte organizam os conteúdos por linguagens e não por ciclos, deixando a cabo da escola e no limite do professor a decisão sobre como organizá-los: "os conteúdos podem ser trabalhados em qualquer ordem, conforme decisão do professor, em conformidade com o desenho curricular de sua equipe". ${ }^{16}$

Aparentemente flexível, tal proposta enuncia a grande questão que paira sobre o ensino da arte: o que significa ensinar arte? Ora, essa estratégia fragiliza o já delicado argumento da arte como conhecimento, pois

esta liberdade - que tem marcado, correntemente, a atuação do professor de arte - é, na verdade, uma faca de dois gumes: não tendo um programa a cumprir, o professor pode desenvolver um trabalho consistente, inclusive atendendo aos interesses da turma, ou pode também se acomodar, "fazendo qualquer coisa", em atividades dispersas e desconectadas, sem um direcionamento claro, tornando-se até mesmo mais dependente do calendário de eventos comemorativos, que acaba por assumir. ${ }^{17}$

Mais adiante no texto, ainda como uma espécie de convencimento, vemos que a ênfase e o trunfo da arte aparecem como um atributo que "favorece ao aluno relacionar-se criadoramente com as outras disciplinas do currículo. (...) Um aluno que exercita continuamente sua imaginação estará mais habilitado a construir um texto, a desenvolver estratégias pessoais para resolver um problema matemático". ${ }^{18}$

O trabalho da invenção não deveria ser considerado monopólio da área de arte, especialmente na educação. Não gostaria de supor que a "criatividade" seja algo que só os professores de arte detêm; essa seria uma visão empobrecida da própria docência. Para Deleuze, é possível ter ideias em qualquer área de conhecimento; as artes não se diferem das ciências,

DUCHAMP, Marcel. “O Ato Criador”. In: BATTCOCK, Gregory. A nova arte. São Paulo: Perspectiva, 2004, p. 73.

ALVES, E. PENNA, M., op. cit, p. 69

Idem, ibidem, p. 37.

BRASIL, op. cit., p. 49

PENNA, Maura. "A orientação geral para a área de arte e a sua viabilidade". In: É este o ensino de arte que queremos? Uma análise das propostas dos Parâmetros Curriculares Nacionais., op. cit. p. 70.

18 Idem, p. 11 
pois ambas são criadoras. Cada uma delas cria coisas diferentes, a matemática cria por funções, o cinema, por blocos de duração, a filosofia, por conceitos conceitos, e, como já apresentado, a arte cria blocos de afectos e perceptos.

Não poderia esta suposta flexibilidade estar mascarando uma dificuldade de se tratar com aquilo que melhor define o processo de criação artístico - o impensado, o novo, o fora?

Mas, partindo dessa premissa, muitos contra-argumentariam que a função dos Parâmetros Curriculares Nacionais estaria perdida, já que não se garantiria, em nível nacional, o estudo de conteúdos. Nesse ponto, seria importante retomar a lição do velho Jacotot, aquele professor apresentado por Jacques Rancière que, em uma aventura intelectual, vai para a Holanda ensinar francês nem saber falar holandês.

Jacotot, nessa empreitada, fez uma importante descoberta, apesar dos seus trinta anos de ofício; ele aprendeu que a aprendizagem poderia prescindir do mestre-explicador, aquele que vai encher seu aprendiz de conhecimento e conteúdo. Sem saber uma palavra de holandês, ele ensinou algo aos seus alunos: por intermédio de um livro bilíngue, eles aprenderam a escrever e a falar francês, sem que o mestre thes tenha dado explicações sobre os elementos daquela língua.

Para além do conteúdo - o francês, no caso, o que interessou Rancière e que pode nos ajudar aqui -, apesar de não haver um intermediário comum - a língua -, algo que se passou naquela experiência funcionou. Jacotot havia ensinado algo. E, ao se conscientizar disso, decidiu ensinar outros conteúdos que desconhecia, como piano e pintura.

O resultado é que não só os alunos aprendiam como também evadiam dos cursos magistrais para ouvirem em francês um homem que dizia que nada tinha a ensinar: "ensinar o que se ignora, desde que se emancipe o aluno; isso é, que se force o aluno a usar a própria inteligência". ${ }^{19}$ Com isso, o que nos ensina Jacotot, pela voz de Rancière, é que é fundamentalmente uma nova postura em relação ao ensino, extrapolando as questões de cada disciplina. É aquilo que, para Foucault, definiria a experiência como

momentos na vida onde a questão de saber se se pode pensar diferentemente do que se pensa, e perceber diferentemente do que se vê, é indispensável para continuar a olhar ou a refletir. ${ }^{20}$

Tanto Foucault quanto Jacotot tratam de uma filosofia e de uma pedagogia de atitude radical, cujo desafio está na busca por novas formas de viver e de pensar por um pensamento estrangeiro, aquele que nos permitiria operar com a arte a partir do que indomável - ou seja, próprio do processo e do encontro entre proposta e aluno, entre vontades partilhadas.

Talvez não seja assim simples, mas poderíamos começar por assumir que, a despeito de

19 RANCIĖRE, Jacques. O mestre ignorante: cinco lições para a emancipação intelectual. Belo horizonte: Autêntica, 2005, p. 34

20 FOUCAULT, Michel. História da Sexualidade II.O uso dos prazeres. Rio de Janeiro: Edições Graal, 1984. p. 13. 
conteúdos e conhecimentos artístico, não se sabe onde o processo criativo vai dar, ignoramos de partida, o seu caminho, aceitamos, com isso, seu caráter disruptivo, estrangeiro e indomável, abrindo, dessa maneira, uma "espécie de 'vão' na linguagem, essa lacuna que faz eclodir o improvável do pensamento".21

21 RIBEIRO, Cintya Regina. "'Pensamento do fora', conhecimento e pensamento em educação: conversações com Michel Foucault". Educ. Pesquisa., São Paulo, v. 37, n. 3, Dec. 2011. Disponível em: $<$ www.scielo.br/scielo. php?script=sci_arttext\&pid=S1517-97022011000300011\&lng=en\&nrm=iso $\rightarrow$. Acesso em: 02/03/2015. 
10, 

Um homem vende um minuto por incríveis 50 mil dólares, outro homem troca favores com presidiários - doa seu tempo livre pelo tempo encarcerado deles. Uma mulher se senta em espaços públicos para escutar histórias de amor...

Como ficções, as obras de arte contemporânea podem se apresentar ao público como algo absolutamente sem sentido e desvinculado do que se entende por arte, e é justamente esse estranhamento que interessa a esta pesquisa. No primeiro caso citado, James Lee Byars explicita, em seu trabalho, a lógica do capital, vendendo literalmente seu tempo a um museu alemão. No segundo caso, o artista mexicano Antonio Vega Macotela, que participou da 29a Bienal Internacional de São Paulo com o trabalho intitulado Time Divisa, apresenta um resultado de três anos e meio de convivência em um presídio, explorando com os detentos intercâmbios baseados na troca de tempo para execução de diferentes tarefas. No último caso, uma intervenção urbana feita em diversos países pela artista brasileira Ana Teixeira, na qual a artista senta-se em uma praça pública e faz tricô enquanto ouve histórias de amor. Todos esses artistas têm em comum o fato de trabalharem fora dos suportes convencionais da arte, redimensionando, assim, as práticas artísticas.

"Quem tem medo da arte contemporânea?" é título de um conjunto de aulas e palestras ministrados pelo crítico e curador Fernando Cocchiarale na Fundação Joaquim Nabuco, abordando justamente a difícil entrada que a arte contemporânea tem para o público em geral, e, em particular, na sala de aula, vemos a grande desconfiança que os professores parecem ter em tratar esse tema. Não apenas na prática cotidiana encontramos entraves: até mesmo ao se fazer uma pesquisa em repositórios de teses e em uma importante revista eletrônica de publicações acadêmicas (Scielo), pouca coisa se encontra relacionando arte contemporânea e educação. 0 que temos aí, majoritariamente, são textos da já referida pesquisadora Ana Mae Barbosa, que datam do final da década de 1980 até 1990.

Mas, afinal, o que causa tanto pavor na arte contemporânea?

Segundo Cocchiarale "habituamo-nos a pensar que a arte é uma coisa muito diferente da vida, dela separada pela moldura e pelo pedestal e, aliás, a arte foi mesmo isso durante a maior parte de sua história. (...) A ideia de uma arte que se confunda com a vida é difícil de assimilar porque os nosso repertório ainda é informado por muitos traços conservadores". ${ }^{1}$

Isso explica a dificuldade em inserir esse tipo de produção no contexto escolar e também a lacuna na produção acadêmica em torno da arte contemporânea e da educação, uma vez que "as dificuldades apresentadas pela arte contemporânea ao espectador são imensas, pois as categorias que identificavam as obras e outras propostas artísticas, até mesmo nas vanguardas, são hoje aleatórias e ainda não definindo um regime básico de absorção e fruição".2 A arte contemporânea na sala de aula parece apavorar a educação, pois ela não oferece bases FASM, 2010, p. 4

FAVARETTO, Celso. "Experiência estética, instituições e educação". Revista Marcelina, ano 3, n. 4, São Paulo: 
estruturais, não é constante, e pouco se adapta a um plano de pensamento do estático e da regra.

Será preciso explorar um pouco este território, a fim de compreender o que tem dentro desse pacote chamado arte contemporânea.

Para iniciar, uma precaução: não se falará em "arte contemporânea" como uma ampla categoria, considerando-se a diversidade característica dessa produção e, justamente, por não se tratar de uma tentativa de generalização.

Uma primeira suposição sobre a pouca receptividade dessa produção na sala de aula certamente está associada à falta de compreensão por parte do público, o que acaba causando estranhamento e distância. Esse efeito é certamente fruto da complexa rede discursiva construída em torno da noção de "arte contemporânea".

Assim, vista como uma grande categoria generalizante, a arte contemporânea parece refratária a qualquer categorização, a não ser a respeito da ideia de pluralismo que a envolve - nesse ponto, os discursos parecem convergir. Entretanto, para não incorrer no equívoco consensual de que o pluralismo é a identidade última da arte contemporânea, o filósofo e crítico de arte alemão Boris Groys adverte: "the alleged pluralism of modern and contemporary art makes any discourse on it ultimately futile and frustrating".

De partida, é bastante sabido que, desde as vanguardas modernas, aquilo que se convencionava ser arte passou por grandes transformações, deixando de ser formulada com a pergunta "o que é belo?" para passar a ser questionada a partir "do que é arte?". Eé aparentemente com esse deslocamento que o problema da inserção dessa produção na escola parece lidar, pois, operando por regras, metodologias ou propostas definidas e ancoradas em um ideal de arte, um discurso que embarace esse conceito dificilmente se adequa a tal formato. Mas, é preciso, sobretudo, encarar esse problema, adentrar nessa discussão, pois entender a complexidade que envolve a produção artística contemporânea pode ajudar a sanar tal problema.

Segundo Anne Cauquelin, a dispersão característica da produção contemporânea fruto de um contexto como o da globalização, parece ter apartado o público da arte, que tem se sentido ludibriado diante de uma complexa rede de informação. Esta rede deixou de operar na linearidade do sistema da arte moderna, cuja linha se definia em produtor, mediador (galeria, marchand e crítico) e público, passando a compor um esquema circular, fenômeno este que gerou novos intermediários (de produtores, especuladores, cotadores, diretores de fundações e espaços culturais, agentes e etc. - inaugurando-se, assim, um novo staff da arte), de forma que todos os agentes podem ocupar qualquer lugar do sistema. Nota-se também que, nesse tipo de sistema (rede), o campo da arte se confunde com o domínio da sociedade.

Daí deriva a posição instável da figura do artista, sendo ao mesmo tempo elementar para a constituição da rede e produto dela. Para permanecer na rede, o artista precisa dispor de inúmeras ligações, que, quanto mais velozes forem, mais eficazes serão. 0 artista deve ainda estimular o máximo de divulgação e repercussão social através de mailings, catálogos, obras em eventos internacionais, viagens, contato com os artistas mais influentes e daí por diante. 
Outra mudança importante desse esquema é que o artista não ocupará mais o lugar de principal autor das mensagens, ou seja, o seu grau de visibilidade depende de toda aquela gama de informações que são veiculadas/fabricadas pelo novo staff da arte. Dessa forma, ainda que não mais considerado o principal nem o único autor das mensagens emitidas pelo sistema, o artista, visto então como produto, é constituinte da rede na medida em que é condição para sua existência. Ele corrobora para o não apagamento da sua figura tradicionalmente concebida como criadora, apesar de ser convocado a estar in ou out em função da aceitação ou não das condições que a rede de comunicação estabelece.

Assim, "por uma circularidade total do dispositivo; vêem-se expostas à vista do público não tanto obras singulares, produzidas por autores, mas uma imagem da rede propriamente dita". ${ }^{4}$ Isso significa dizer que quando vemos uma obra de arte contemporânea estamos lidando não com um trabalho de arte mas com um sistema de autorreferenciação. Desse circuito circular deriva, certamente, o hermetismo do qual muito se fala em torno dessa produção.

Portanto, inseridas nesse contexto de dispersão generalizada, as obras contemporâneas "não são em princípio governadas por regras já estabelecidas, e não podem ser julgadas por regras já determinadas, e não podem ser julgadas mediante um juízo determinante, aplicando a esse texto, a essa obra, categorias conhecidas. Estas regras e estas categorias são aquilo que a obra ou o texto procura". ${ }^{5}$ Essa indefinição gera para o público uma grande confusão, pois, apesar de a arte contemporânea não apresentar de antemão critérios e regras para o seu entendimento, é quase consensual a afirmação que, como efeito dessa pluralidade, ela produz, por um lado, uma sensação "estranha", como descreve Ronaldo Brito, e, por outro, mas também por conta desse caráter, entra facilmente na categoria do "interessante", como descreve Jean Gallard.

Parece que, apreensões da arte contemporânea, talvez pelo seu caráter disruptivo e sem regras a cumprir de véspera, tendam a ser ineficazes, pois "every attempt to formulate a theoretical definition of art has provoked an attempt by the artists to produce an artwork that would escape this definition, and so on". ${ }^{6}$ Seria como se houvesse um saber da arte que precisasse resistir para se sobrepor às definições.

No entanto, de acordo com Boris Groys, talvez a única afirmação que pode ser feita a respeito da arte contemporânea é que, em última instância, ela precisa ser paradoxal: conter em si tese e antítese, ser como a Fonte de Duchamp - ao mesmo tempo arte e não-arte, ou, então, como para Jaspers Johns, ser objeto (bandeira), pintura e representação de uma bandeira, para usar um exemplo de De Duve.7 Isto é, "to be a paradox-object is the normative requirement implicitly applied to any contemporary artwork" ${ }^{8}$ Acrescenta-se a essa afirmação que o paradoxo ao qual a obra de arte contemporânea se filia será a arte moderna e sua história, numa tentativa de aglomerar "informações díspares", como diz Brito, compondo reavaliações do passado que

\footnotetext{
4 CAUQUELIN, Anne. Arte contemporânea: uma introdução. São Paulo: Martins Fontes, 2005, p. 74. LYOTARD. Jean-François. 0 pós-moderno explicado às crianças. Lisboa: Dom Quixote, 1987, p. 26. GROYS, Boris., op. cit. p. 6.

DUVE, Thierry de. "Sintoma e intuição". Revista Novos Estudos-CEBRAP 79 (2007), p. 217. Disponível em: $\leftarrow$ www.scielo.br/scielo.php?pid=S0101-33002007000300011\&script=sci_arttext $\rightarrow$. Aceso em 01/08/2014.

$8 \quad$ GROYS, Boris., op. cit., p. 4.
} 
geram novas e assim por diante.

Obviamente, essa ampliação do campo da arte provoca remanejamentos e tensões que lidam diretamente com o público, colocando em jogo a recepção da obra de arte e interferindo no tipo de expectativas que o público apresenta diante do trabalho de arte. A mudança no estatuto da imagem, que deixa de ser concebida como tal para tornar-se algo que Alain Renaud chama de "visibilidade cultural" (esta, fomentada pelas tantas novas tecnologias), apresenta uma sorte de experiências virtuais e sensíveis que extrapolam o tipo de experiência do olhar, e particularmente, do Belo, como a que o público parece requerer.

De fato, o público parece lidar com essa espécie de estetização generalizada sem uma definição clara do sentido da experiência artística, sendo a recusa ou a captura suas principais formas de enfrentamento da questão. A primeira, certamente, diz respeito ao discurso que circula na educação numa primeira instância. Já a segunda diz respeito aquilo que Groys denomina "cultura do excesso de gosto".

O pluralismo que envolve a arte contemporânea e todo o tipo de obras que ela pode criar cobre uma ampla gama de diferentes gostos, do popular ao erudito, mas que, sobretudo, instaura também na arte uma espécie de cultura do excesso do gosto. Certamente, seria dessa produção que resultam as categorias "estranha" e "interessante" pontuadas por Ronaldo Brito e Jean Gallard, respectivamente.

Essa cultura do gosto nada mais reflete do que expectativas de um público. Parece haver por trás dessas expectativas uma vontade, por parte do público, de que a experiência artística venha justamente romper o caos e dar uma espécie de unidade de sentido para uma sociedade tão dispersiva. Tal vontade parece condizer com esse tipo de expectativa com que a educação encara a arte, rechaçando a arte contemporânea do seu espaço, em uma tentativa de expulsar aquilo que se desconhece e que não apresenta consigo um manual de instruções. O que significa dizer que, em última instância, a arte contemporânea parece chegar às escolas não apenas pelo seu caráter disruptivo, mas também pela manutenção de um certo gosto.

Um primeiro ponto de interesse na articulação entre arte contemporânea e educação reside no fato de que, ao esgarçar todos os limites materiais que definiam arte até a modernidade, costuma-se atacar, de partida, as concepções de arte calcadas na ideia do gênio e da originalidade, bastante arraigadas nos discursos em nome da arte que circulam na educação e que contribuem para afastá-las da sala de aula como uma espécie de fantasma.

Conforme Jacques Rancière, "as práticas artísticas são 'maneiras de fazer' que intervêm na distribuição geral das maneiras de fazer e nas suas relações com maneiras de ser e formas de visibilidade". 9 Quais visibilidades a educação propõe à arte contemporânea, ou quais visibilidades a arte contemporânea oferece à educação?

Trazer para a sala de aula operações artísticas contemporâneas como dispositivos seria uma maneira de operar através dos rearranjos tanto nos modos de sociabilização quanto nos modos de vida que alguns projetos artísticos apresentam. 
Em segundo lugar, conforme descrevem Boris Groys e Ronaldo Brito, as práticas artísticas não cessam de escapar aos rótulos, em uma espécie de desterritorialização constante. Mas que reterritorialização ela provoca quando entra em contato com a escola?

E, por último, a arte contemporânea nos propõe uma sorte de experimentações e proposições que nos aproximam da ideia de arte deleuze-nietzschiana apresentada nesta pesquisa, as quais podemos perguntar: "O que pode advir dessa maneira de pensar como matéria de ensino ou de aprendizado senão a concentração na especificidade e singularidade do trabalho dos artistas?". ${ }^{10}$

O que se espera do manejo com práticas artísticas contemporâneas é encontrar pistas para a criação de novos dispositivos e/ou outros pontos de contato entre arte e educação. Sem, com isso, colocar a arte em subordinação à educação, como instrumento de desenvolvimento de teoria ou metodologia aplicável tanto à educação como ao ensino de arte. Tampouco propõe-se ignorar a existência daquele sistema complexo descrito anteriormente, no qual a arte contemporânea está inserida.

Entretanto, o discurso educativo em torno da arte contemporânea, especialmente produzido pelas instituições culturais - museus e centros culturais -, parece querer sanar a todo custo o hiato entre público e obra, insistindo em uma aproximação através de estratégias que funcionam e entendem a atividade contemporânea como "uma modalidade de lazer, um exercício superior da fantasia". ${ }^{11}$

Nessa direção, tentar transformar a arte contemporânea e sua ausência de regras préestabelecidas em um conteúdo ou ainda um fundamento da prática docente parece um anseio análogo ao trabalho educativo feito em instituições culturais, e, ainda, equiparado aos seus discursos - como suplemento capaz de sanar essa distância. Vale a ressalva que na ausência sintomática de bibliografia relacionada ao assunto, as instituições culturais têm, cada vez mais, ocupado o lugar de formação dos professores de arte, especialmente quando o assunto é arte contemporânea. Ora, não é gratuito que, no interior da educação básica, sejam reforçados preconceitos que servem para manter o distanciamento, ainda que visem, como forças pedagogizadas, resolvê-lo ou diminuí-lo. 

Leitura de imagens, cópias, reproduções, releitura, produção artística. Configurações bastante enraizadas de uma cultura escolar da aula de arte. Sem esquecer que também faz parte dessa cultura a prática do desenho livre, as datas comemorativas, as festas juninas, a massinha, etc.

É sabido que na história da arte - e se quisermos numa pré-história do ensino das artes - quando a relação mestre e aprendiz pautava a aprendizagem do ofício do artesão e do artista, a cópia dos cânones clássicos e neoclássicos era metodologia. Há, ainda hoje, claramente um fetiche que envolve a figura do artista como aquele que, com habilidade, é capaz de copiar os grandes mestres. Picasso copiava os grandes pintores no Museu do Prado com inegável primazia.

Mas, quando entramos no chão da escola, onde não se trata de formação de artistas, essa prática é revisitada com o nome de "releitura". A pesquisa sobre o uso de imagens em sala de aula iniciou-se na década de 1970, nos Estados Unidos, com pesquisadores como Abigail Housen, Michael Parsons, Feldman, etc. Tratava-se, em geral, de abordagens cognitivistas sobre o desenvolvimento estético das crianças, baseada na descrição das imagens - naquilo que pode ser visto. Aqui no Brasil, neste mesmo momento histórico, o laissez-faire era a tônica da aula de arte, portanto esse tipo de abordagem centrada na imagem ainda não figurava entre as práticas comuns em sala de aula.

No entanto, como resposta ao "excesso de inspiração criadora" própria da concepção da Livre-Expressão, na década de 1980 vemos o surgimento da Proposta Triangular (anteriormente denominada Metodologia Triangular), como parte importante do movimento de constituição da Arte-educação como área de conhecimento e pesquisa.

Trata-se de uma proposta sistematizada pela pesquisadora e arte-educadora Ana Mae Barbosa, cujo objetivo era criar "um currículo que interligasse o fazer artístico, a história da arte e a análise da obra de arte". ${ }^{1}$ Oriunda de uma metodologia de ensino da arte desenvolvida nos Estados Unidos, chamada DBAE - Disciplined-Based-Art Education, cujas bases são pensadas a partir da produção de arte, crítica, história e estética, que segundo Elliot Eisner, um de seus idealizadores, corresponderiam às quatro operações mais importantes que as pessoas fazem com arte. ${ }^{2}$ Assim, a Proposta Triangular é o elemento-chave para a construção de um discurso que vinculará de vez a arte na educação através do binômio metodologia-conhecimento.

No entanto, ao apresentar tal metodologia no Brasil, Ana Mae, "por razões de necessidade"3, preferiu unificar estética e crítica no que chamou de leitura de obra. Desta forma, a leitura de obra tornou-se o princípio fundamental da Proposta Triangular, do qual as outras operações parecem derivar, formando uma espécie de hierarquia: primeiro a imagem, seguida de sua contextualização e por fim, o fazer como releitura.

Tal configuração elevou a imagem à condição de novo paradigma da aula de arte, uma

BARBOSA, Ana Mae. A imagem no ensino da arte. Anos oitenta e novos tempos. São Paulo: Perspectiva, 2009. p. 35. EISNER, Elliot. apud BARBOSA, Ana Mae. ibidem. p. 36.

BARBOSA, Ana Mae. ibidem. p. 94. 
vez que o conteúdo e a leitura de imagem se tornaram imprescindíveis para a prática em aula - por sua vez, também atrelada à uma instrumentalização do olhar - o próprio fazer artístico passou a se pautar pela imagem-modelo.

Analice Dutra Pillar faz uma importante pesquisa acerca da leitura e releitura no contexto escolar. Em sua análise, dependendo de como for feita, a leitura pode tornar-se uma atividade meramente técnica e "em muitos momentos, faz com que a leitura aprisione a obra". ${ }^{4}$ Já a respeito da releitura, a pesquisadora sublinha um cuidado: "a cópia diz respeito ao aprimoramento técnico, sem transformação, interpretação e criação". ${ }^{5}$ Ou seja, para a pesquisadora, sem reconstrução e ressignificação não há sentido na releitura.

Se, por um lado a Proposta Triangular colaborou para a inserção das imagens de arte na sala de aula, antes esconjuradas por influenciar o processo de criação genuína do aluno, pelo outro, tornou-se uma espécie de bíblia da sala de arte. Em retificação a isso, Ana Mae propôs a mudança de "Metodologia" para "Proposta Triangular": "estou convencida de que metodologia é construção de cada professor em sua sala de aula e gostaria de ver a expressão Proposta Triangular substituir a prepotente designação Metodologia Triangular". ${ }^{\prime}$

Ainda que a mudança de nome tenha se efetivado, o mesmo não parece ter ocorrido com a prática em sala de aula, já que um dos vértices deste triângulo - o fazer, continuou sendo entendido como releitura. Apesar dos esforços de Ana Mae e de outros pesquisadores em delimitar a diferença entre os dois termos, o que se vê é a identificação entre reinterpretar e "copiar".

Para essa vertente de pesquisadores a releitura seria um trabalho que envolveria transformar e recriar como sinônimos de criação. Segundo a pesquisadora Analice Dutra Pillar, "o importante é que o professor não exija representação fiel, pois a obra observada é suporte criativo e não modelo para os alunos copiarem". 7 . Esse uso das imagens em sala de aula, aparentemente, cumpre o papel de interligar os outros dois vértices do triângulo: o que diz respeito à fruição de obras e o que, por sua vez, faz a sua contextualização. Porém, uma rápida olhada em livros didáticos e material produzido por museus para professores, nos mostram que a leitura proposta é, na maioria das vezes, formal ou psicologizante.

Um dos pontos frágeis da prática de leitura e releitura de imagens na sala de aula reside no fato de terem se tornado uma metodologia, que por si só parece um contra-senso, pensando que sua "aplicabilidade" se dá especialmente para as obras até a modernidade, cujo interesse da discussão girava basicamente em torno dos elementos formais e especificidades de cada gênero ou modalidade artística. Se levadas a cabo no contexto contemporâneo - que transborda esse tipo de noção de imagem, a partir de experimentos híbridos entre as linguagens e gêneros anteriormente canonizados como a pintura e a escultura - o que pode oferecer a leitura e releitura de obra-primas nas aulas de arte?

\footnotetext{
PILLAR, Analice D. A educação do olhar no ensino das artes. Porto Alegre: Mediação, 2009. p.16. Idem, p. 18.

BARBOSA, Ana Mae. Tópicos utópicos. Belo Horizonte: C/Arte, 1998. p 33.

BARBOSA, Ana Mae. A imagem no ensino da arte. p. 107
} 
Sobre o hibridismo característico da produção contemporânea, Donald Judd, artista minimalista, em um notável texto, nos apresenta uma noção que a partir da década de 1960 , servirá de alcunha para inúmeras reflexões e produções artísticas.

Em Objetos específicos, Judd faz um panorama sobre a produção artística feita em torno da década de 1960, para demonstrar que as categorias como pintura e escultura, enquanto continentes, não tem servido para caracterizar a produção que havia sido feita. Segundo o artista, tanto a pintura quanto a escultura "são formas particulares circunscritas, enfim, produzindo qualidades razoavelmente definidas. Grande parte da motivação adjacente aos novos trabalhos é livrar-se de tais formas". 8

No entanto, estes novos trabalhos têm poucas afinidades entre si, talvez, para Judd, a tridimensionalidade possa ser o seu aspecto mais comum, tendo se tornado "um espaço para mover-se". .0 que impossibilta que se transformassem em um movimento ou escola. Talvez para além de demonstrar certo desinteresse pelas categorias canônicas - pintura e escultura - os novos trabalhos se assemelhem mais à escultura do que à pintura. Além disso, a maior parte dos novos trabalhos usam materiais diferentes dos materiais convencionais da escultura (bronze, madeira, mármore), eles usam materiais específicos, que não eram utilizados na arte até então usam materiais industriais. A quantidade de materiais disponíveis é tão grande e seu uso na arte não se dá de maneira fácil como o emprego de óleo sobre tela, são de difícil associação entre eles - e é isso que os torna objetos específicos.

Os objetos específicos, estão na fronteira daquilo que está no cotidiano e na arte, eles dependem do conhecimento que o espectador tem sobre aqueles materiais, eles produzem outras combinações entre os elementos do real e na sala de aula, de que forma seria possível propor uma leitura e releitura desse tipo de trabalho sem, contudo, operar numa redução do que está posto em jogo em cada um desses objetos?

No entanto, para Ana Mae Barbosa, a proposta triangular traz um "enfoque metodológico [que] vem transformando o ensino da arte e dando-lhe uma fisionomia pós-moderna". ${ }^{10}$ Porém, ao operar na chave da leitura e releitura de obras - como construções formais, parece assumir uma perspectiva bastante próxima da modernidade. Funcionando, pois, como anteriormente dito, dentro de um escopo histórico que, se delimitado até o modernismo, satisfaz plenamente essa identificação entre arte e imagem. Talvez isso responda a insistência que é possível encontrar no uso de obras de arte do modernismo brasileiro e europeu nas aulas de arte. No entanto, o problema torna a emergir, de maneira ainda mais evidente, quando essa associação arte e imagem - também se endereça às demais linguagens artísticas que trabalham, sob a ótica dos Parâmetros Curriculares Nacionais, não coincidentemente, com a mesma noção de leitura de imagem. Música, teatro e dança acabam tendo suas especificidades suprimidas a uma lógica que funciona especialmente às artes visuais, e ainda, num recorte que vai até a arte moderna.

Há ainda um outro ponto que precisa ser sublinhado quando associamos a imagem e

8 JUDD, Donald. Objetos Específicos. In: FERREIRA, G. COTRIM, C. Escritos de artistas: anos 60/70. Zahar, 2006. p. $96-97$.
9
Idem, ibidem, p.102.

10 BARBOSA, An Mae. A imagem no ensino da arte. p. 89 
sua leitura a uma espécie de discurso esperado da figura do artista, algo como uma interioridade a ser desvelada, bastante preconizado em visitas a museus e em sala de aula, reconhecido na pergunta: "O que o artista quis dizer?" Sobre isso Tacita Dean, artista contemporânea inglesa, cujo interesse se desdobra sobre o silêncio afirma que não saberia dizer ao certo as suas intenções com cada uma de suas obras: "eu me pergunto se uma pessoa pode saber realmente por que faz certas coisas. Falar de suas motivações é algo muito complicado para os artistas". ${ }^{11}$

Em 1945, Marcel Duchamp, no texto "O ato Criador", já escrevera sobre o processo de criação artística como uma ação conjunta, dependente de dois pólos - um de lado o artista e do outro o público. Para Duchamp e toda uma geração de artistas herdeiros "da utopia moderna de renovação da vida, patente das vertentes construtivistas e dada-surrealistas, reprocessada e reativada na arte dos anos sessenta e setenta, e que continua presente nos interesses de muitos artistas até agora"12, a arte é tida como uma atividade, uma ação, na tentativa, inclusive de desestetização da arte e desmistificação do trabalho do artista tido como virtuose.

Duchamp, no texto acima, na tentativa de descrever o processo subjetivo de criação, sem entrar no mérito das definições e julgamentos estéticos do que é arte ou uma boa arte, nos fala do ato criador como uma equação, "como uma relação aritmética entre o que permanece inexpresso embora intencionado, e o que é expresso não intencionalmente". ${ }^{13}$ Ou seja, ainda que haja, segundo o artista, alguns artistas que torçam o nariz para esse tipo de afirmação que aponta para a indeterminação como parte do processo, visto que preferem dar justificativas racionalizadas sobre seus processos de criação, é da ordem do desconhecido o processo criador e, principalmente, de caráter incompleto, visto que cabe ao público "determinar o peso da obra de arte na balança estética". ${ }^{14}$

Desse ponto de vista, a leitura de obra seria uma parte da criação - aquela que dá significado ao trabalho, mas, ainda assim, por que todos querem perguntar aos seus alunos: 0 que $\mathrm{o}$ artista quis dizer?

Como se houvesse uma transcendência possível daquilo que se apresenta como obra. Que tipo de apreensão de arte esse exercício produz?

Por curiosidade, numa pesquisa trivial no maior buscador da internet pesquisei imagens relacionadas com "releitura de obra arte-educação". É incrível a quantidade de Tarsilas do Amaral, Cândidos Portinari, Alfredos Volpi, para ficar no contexto brasileiro, mas se o extrapolarmos revela-se uma grande incidência de Picassos, Van Goghs e Munchs, o que parece sinalizar que a temática modernista foi a eleita para configurar a leitura de imagem, e portanto, a sua releitura.

No entanto, essa eleição parece ser feita apenas do ponto de vista formal, algo como se o estético prescindisse do político. Nesse sentido, para tentar entender como se inscrevem essas práticas e que entendimento da arte ela evocam, visto que remontam, ainda que seja apenas imageticamente ao modernismo, lanço mão daquilo que o pensador francês Jacques

DEAN, Tacita. IN: OBRIST, Hans Ulrich. “Entrevistas-vol. 3.” (2009). p. 151.

FAVARETTO, Celso. Deslocamentos: entre a arte e a vida. Revista ARS. Ano 8, n. 18. p. 96.

DUCHAMP, Marcel. O Ato Criador In: BATTCOCK, Gregory. A Nova Arte. São Paulo: Perspectiva, 2004. p. 73.

Idem, ibidem. 
Rancière chamou dos três grandes regimes de identificação da arte, numa tentativa de entender a produção artística oriunda da modernidade.

Em primeiro lugar, Rancière ressalta que "a noção de modernidade estética recobre, sem the atribuir um conceito, a singularidade de um regime particular das artes, isto é, um tipo específico de ligação entre os modos de produção das obras ou das práticas(...)," ${ }^{15}$ visto que comumente a análise dessa produção desconsidera seu aspecto político, de rupturas e modificações nos modos de fazer.

O primeiro regime, chamado de ético, parece anteceder a identificação da "arte" como tal". Trata-se de um modo de produção de imagem que se liga diretamente a sua função ética - o que dela diz respeito aos indivíduos e ao coletivo?

Neste regime,"a arte" não é identificada enquanto tal, mas se encontra subsumida na questão das imagens". ${ }^{16}$ As imagens pertencentes a esse regime são as imagens de divindade, o que vai importar é a sua origem e a sua finalidade (quais uso e efeitos terá).

Seria como querer conferir estatuto de pintura às imagens sagradas, na tentativa de deduzir do seu estatuto ontológico o próprio da arte.

Já o segundo regime, chamado de representativo, há identificação da arte (na idade clássica - belas artes), mas sob o estatuto da representação ou mímesis. Para Rancière, por mimético entende-se não um modo de operação artístico, mas um regime de visibilidade da arte. É pela chave da representação que a distribuição da arte será feita. Será portanto, sob o signo da mímesis que serão fornecidas as categorias para julgar se uma obra é boa ou não, é a partir daí que são constituídos os gêneros daquilo que pode ou não ser representado e daí para frente. Para o pensador francês, esse regime é poético, pois funda a noção de arte - Belas-Artes - e também representativo, pois, é sob esse regime que organiza as maneiras de ver, valorar e fazer arte.

No entanto, há uma importante ressalva, esta que funciona muito bem para o tipo de proposição que se engendra na prática de leitura e releitura de obras: a ideia de mímesis não pode ser considerada como um procedimento artístico, ela é antes "um regime de visibilidade das artes [que] é, ao mesmo tempo, o que autonomiza as artes, mas ao mesmo tempo o que articula essa autonomia a uma ordem geral das maneiras de fazer e das ocupações". ${ }^{17}$

Por fim, há o chamado regime estético, que opera em oposição aos dois regimes anteriores, pois nele a identificação da arte não se faz por distinções nas maneiras de fazer e sim sobre uma maneira de ser sensível ao próprio trabalho de arte. A estética, no caso, não se referirá à sensibilidade e sim ao modo de ser propriamente das coisas da arte.

Esse tipo de regime, por tornar a arte um sistema próprio e complexo, autoriza a confusão sob a qual se constitui a chamada modernidade, principalmente, pois, é esse regime que identifica a inexistência de regras estabelecidas próprias da arte, elevando-a a um estado de suspensão que rompe com a barreira mimética que definia o modo de fazer próprio da arte.

RANCIÈRE, Jacques. A partilha do sensível. p. 28

Idem, ibidem.

Idem, ibidem, p. 31-32. 
Acerca deste regime se constroem dois discursos em torno da modernidade: um que sustenta a autonomia da arte, opõe moderno e antigo, como as teorias de rupturas históricas; o outro, com um discurso chamado modernitarismo, que apresenta a arte como uma espécie de autoformação da vida pautada na noção estética do homem schilleriana.

Para Rancière, a modernidade como fruto desses dois discursos parece ter operado, propositadamente, "para confundir a inteligência das transformações da arte e de suas relações com as outras esferas da experiência coletiva". ${ }^{18} \mathrm{~A}$ modernidade, segundo o autor, fusiona o regime estético ao seu próprio nome, tornando-se uma denominação confusa. "Em suas diferentes versões, 'modernidade' é o conceito que se empenha em ocultar a especificidade desse regime das artes e o próprio sentido da especificidade dos regimes da arte. Traça, para exaltá-la, uma linha simples de passagem ou ruptura entre o antigo e o moderno, o representativo e o nãorepresentativo e o anti-representativo". ${ }^{19}$

Sem se dar conta ou sem levar em conta tais tramas constitutivas da modernidade, Ana Mae Barbosa, na primeira importante pesquisa fundamentadora do uso da imagem em arteeducação, traz obras do Museu de Arte Contemporânea da USP, museu do qual ela era diretora na época, como estudo de caso de leituras de imagens. Por consequência (intencional ou não), por se tratar de um acervo marcadamente formado por obras modernistas, o modernismo parece ter se fixado como uma fórmula para os professores da arte, haja visto a quantidade de imagens encontradas de releituras dessas obras na internet.

Ainda que o regime estético tenha se confundido com os discursos sobre a modernidade, me parece que a prática da releitura se relaciona principalmente com os dois primeiros regimes que aponta Rancière para deles derivar o terceiro como substrato para se afirmar epistemologicamente a arte como conhecimento. A relação que se estabelece com a leitura de imagem se aproxima do regime ético das imagens na medida em que parece buscar extrair da imagem a priori o seu caráter ontológico. Ainda que não submersas à lógica da cultura visual - uma vertente mais recente do ensino da arte - as imagens utilizadas são caracterizadas de partida como arte e o tipo de leitura e releitura propostas reforçam a estandardização de um tipo de arte que no geral aparece relacionada à mímesis - no sentido trazido por Rancière - como um regime de visibilidade.

É neste ponto em que o regime ético da leitura de imagens se encontra com o seu regime representativo. Ora, se a leitura evidenciará aspectos formais da obra de arte, é preciso que essa obra funcione sob um determinado regime de visibilidade. Um tipo de distribuição da arte que dê conta disso precisamente deve ser uma arte em que os aspectos formais se apresentam como questão, e portanto, aparentes.

Nessa leitura encontramos o ponto de inflexão no qual é possível perceber a noção de modernidade trazida pelo discurso da leitura e releitura de imagens que se alinha dentro do regime estético da arte com os discursos que a identificam com "uma revolução antimimética", 
na qual a arte teria se voltado a si e às suas especificidades, como se à pintura coubesse discorrer sobre o bidimensional e a cor. Disso decorre, talvez, a força que essas imagens parecem ter na sala de aula, cuja noção de arte parece pouco interessada nas misturas e hibridizações que os gêneros e suportes foram sofrendo desde a modernidade. 


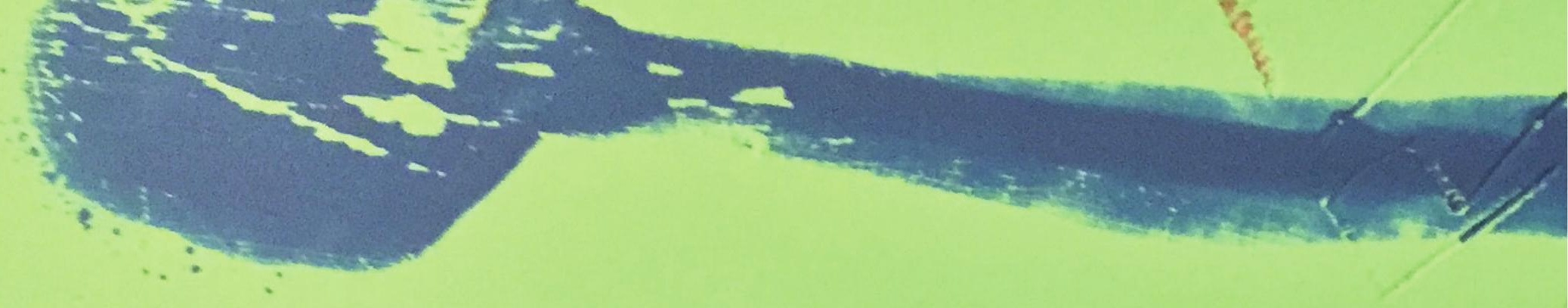

a.

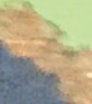

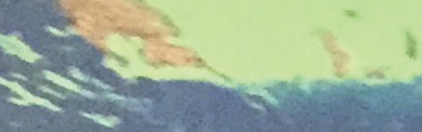

$+\infty$

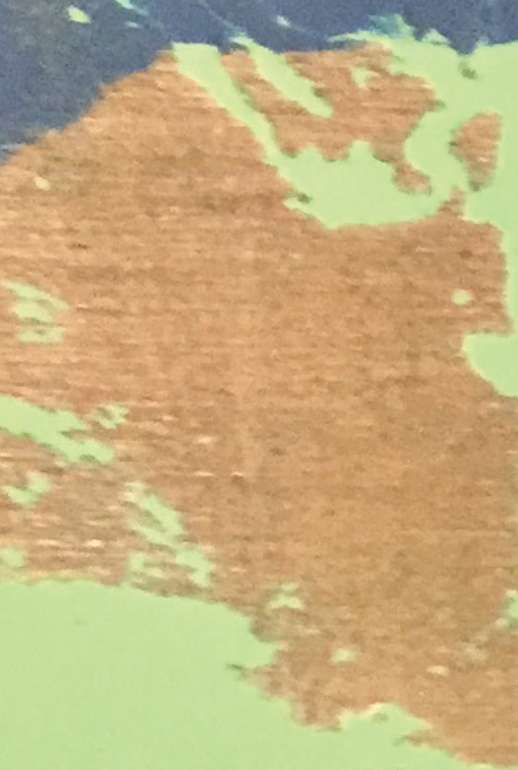

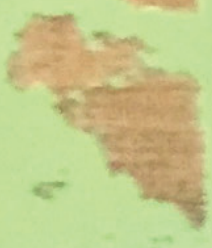

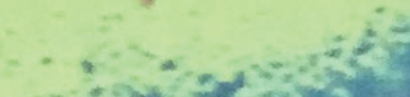
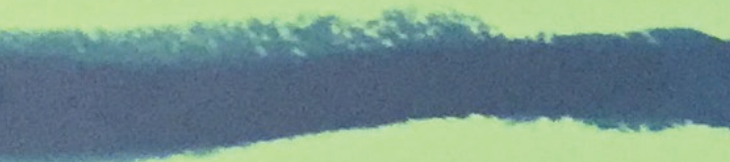


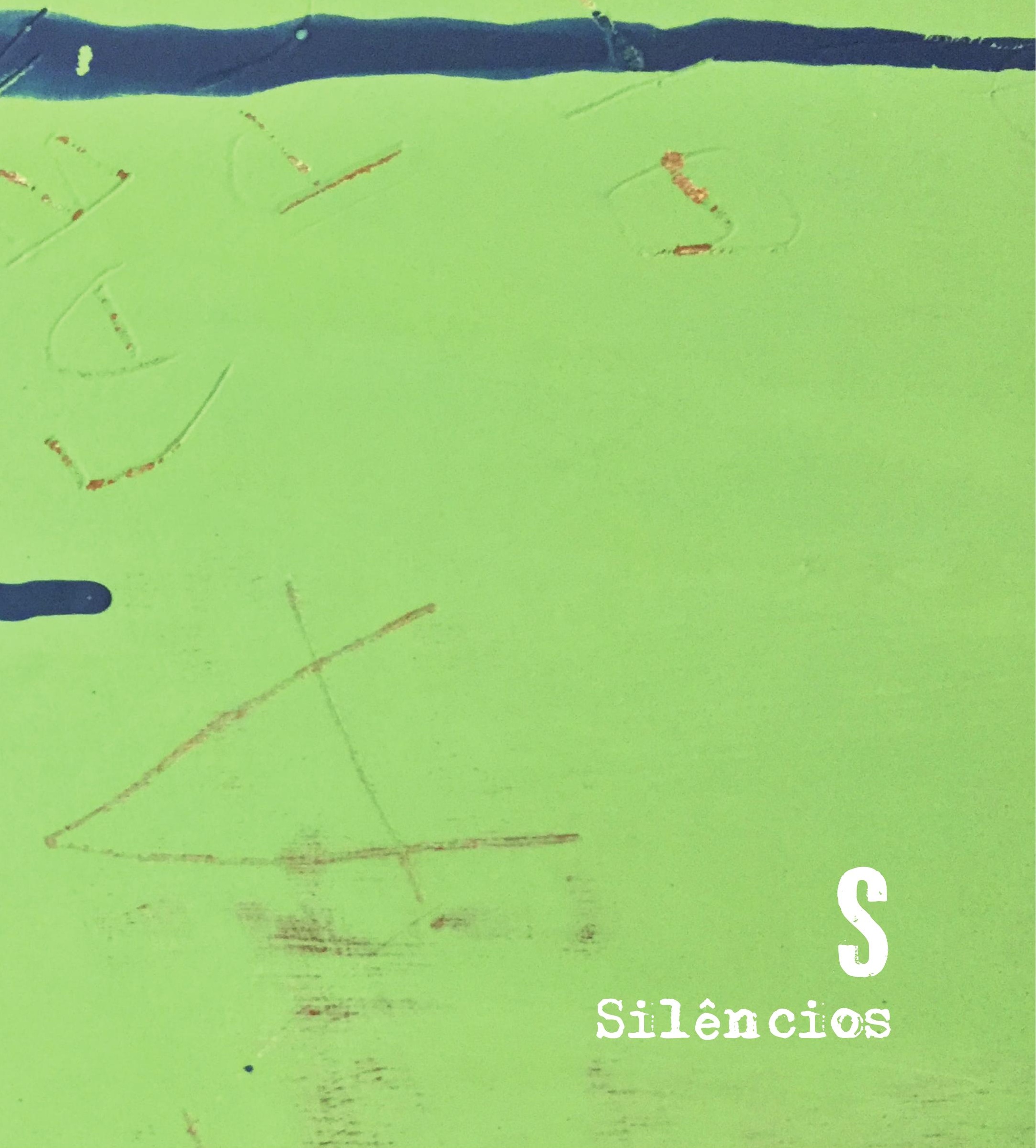



Sinal toca. Sala de aula. Silêncio. Espaço revirado, cadeiras e mesas fora do lugar. Alunos chegam e não gostam do que veem - eles parecem não gostar de mudanças. Ensino Médio, um contrato: não ver absolutamente nada durante uma hora. "Mas, mas, mas..." cheiro de excitação e medo. Confiança é a premissa do contrato.

Eu silencio as risadas, eles ocupam as cadeiras. Coloco a venda nos olhos, aperto mas não muito, verifico se há passagem de luz, dezenove vezes consecutivas. Começo do experimento. Passo os mais diferentes objetos pelas mãos de cada um: lixa, massinha, bucha, mármore, tela, arame, pena de pavão, esponja de aço, tule, algodão, bola pequena de ferro. Um a um, cada novo objeto em novas mãos causam estranhamento, gritos, risadas, brincadeira.

Agora os cheiros, incensos, essências, frutas cortadas, tinta velha, perfume, temperos. Um exercício de se aprofundar em cada um e em sua experiência, nas memórias exaladas. Cada vez mais compenetrados, aquilo que era excitação e medo virá um mergulho maior.

Lembro-me: "Uma aula só pode ser uma obra de arte com aquele professor que se confunde com a matéria, que deixa de ser o sujeito de um conhecimento e se torna o corpo pelo qual os devires da matéria deixam inundar os corpos daqueles que ali vieram aprender". ${ }^{1}$

Passamos para o paladar, duas desistências - medos e dificuldades; sair do lugar confortável nunca será tarefa a ser menosprezada. Incorporo essas alunas como cúmplices, junto ao estagiário que me acompanha. Oferecemos a cada boca semi-aberta: laranja, marshmellow, café amargo, boldo para mascar, damascos, limão, uvas, geleia de pimenta, chocolate, amendoim, mandioquinha...

Nesse momento, grande excitação de difícil contorno. Olhares curiosos dos que passam a se perguntar "o que eles estão fazendo?" viraram uma tônica deste espaço flutuante que habitamos, juntos, todas as quintas-feiras pela manhã.

Fim da experiência e, afinal, o que isso tem a ver com arte?

Explanações. Assertivas. Não resta dúvida que ali naquele espaço a arte está nas mais simples proposições. Problematizo: Então comer é arte? Disparos: gastronomia, futebol-arte, etc. "Não acho que comer seja arte, mas trazer comida assim, para a gente experimentar, mexer com os nossos sentidos é um jeito de despertar arte na gente", conclui-se.

A partir da possibilidade de trazer as experiências da arte participativa de Lygia Clark como conteúdo para reapresentar a sala de aula como um espaço de sentir, percebo que se fez um elo ainda maior. A noção de participação configura um vínculo entre eu e o outro (meus alunos), no qual, nesse primeiro momento, o professor é o propositor e os alunos, participantes. Dessa proposta em diante houve uma mistura entre proposição e participação, que, ora partia deles e eu atuava como participadora, ora acontecia o contrário.

"Ah! Isso é coisa da Kelly!" costuma ser a afirmação/exclamação que os alunos do Ensino

1 ZORDAN, Paola. Arte com Nietzsche e Deleuze. Revista Educação e Realidade,. v. 30. Porto Alegre,: Jul/dez 2005. Disponível em: <http://seer.ufrgs.br/educacaoerealidade/article/view/12472 $\rightarrow$. Acesso em: 20/10/2014 ... p. 265. 
Médio da EAFEUSP usam para significar estranhamentos (intervenções, frases coladas em pilares, palavras, bexigas, etc.) que vão encontrando pelo pátio da escola. O desejo de decodificar e dar forma, nesse caso, não traduz uma despotencialização do trabalho. Ao contrário, ele parece identificar que intervenções, cartazes, panfletagens e barragens podem ser arte. Ou seja, trata-se de uma aproximação entre arte e vida.

Neste caminho dentro da escola, esse tipo de abordagem corre sempre algum risco: de não ser compreendida, seja por não inspirar a beleza (que tanto se espera da aula de arte), seja por não fazer sentido, visto que muitas intervenções são sutis e de ampla interpretação. Principalmente porque estão inseridas no ambiente escolar, essas intervenções com objetos cotidianos, em diálogo franco com a produção artística contemporânea, passam muitas vezes pelo silencioso e desconfiado olhar.

No meio desse processo, aprendi o valor do silêncio. Antes, o que se considerava silêncio era aquele pequeno poder que o professor se gabava por exercer, ou seja, resquícios de uma lógica do controle e disciplinamento. Ainda que sem consciência disso, passei algum tempo acreditando que o silêncio era algo a ser perseguido e, quando alcançado, era sinônimo de "sucesso" - mesmo que não fosse verificador da qualidade de aula, eu sentia que o silêncio era sinônimo do trabalho de "um bom professor". Ou, ainda, o silêncio poderia se caracterizar, em sala de aula, como apatia, afronta, descomprometimento e recusa. Muitas vezes alunos simplesmente se ausentam da aula sem sair da sala, neste caso, o silêncio prescrito para o bom funcionamento da aula ocorre, mas não significa engajamento.

No entanto, a experimentação em sala de aula me trouxe uma outra perspectiva para o silêncio, ou melhor, para os tipos de silêncios.

O silêncio como um espaço-tempo de concentração de cada um; o silêncio como aquele curto, médio ou longo período de tempo em que cada aluno se conecta consigo e com seu trabalho. Mesmo que ocorram, por vezes, no meio da agitação do trabalho coletivo, em rompantes, em átimos, há que perseguir, ou melhor, ensinar os alunos a procurar esse lugar.

No caminho das proposições sensoriais, ainda com o Ensino Médio, esbarramos na concentração - silêncio como uma prática de aula. De diferentes formas, buscamos maneiras de se haver com a quietude de cada um. Foram experimentos difíceis, afinal, trata-se de adolescentes, mas sentíamos o momento em que todos estavam conectados pelo fio tênue da concentração silenciosa.

Com isso, pudemos estabelecer um outro lugar para o silêncio, que vinha antes como prerrogativa de aula e que se tornou um foco a ser encontrado por cada um, sem pressão, pois nesse caminho investigativo, descobrimos que o silêncio como ausência de som é inexistente, e, nesse caso, o que poderíamos fazer era compor com os silêncios de cada um no seu tempo.

Há uma famosa anedota envolvendo o músico e compositor John Cage (1912-1992), que costumo usar em diferentes momentos e em diferentes séries que trabalho. Trata-se do evento em que Cage decidiu escutar o silêncio absoluto. Em 1951, foi a Harvard visitar uma câmara anecoica projetada à prova de qualquer som. Sobre o feito, que se tornou famoso na 
história da música contemporânea, Cage diz:²

Com efeito, por mais que tentemos, não conseguimos fazer o silêncio. Para certos fins de engenharia, é desejável ter uma situação tão silenciosa quanto possível. Tal recinto é chamado de câmara anecoica, suas seis paredes são feitas de um material especial, um quarto sem ecos. Entrei em um destes na Universidade de Harvard há vários anos atrás e ouvi dois sons, um alto e o outro baixo. Quando os descrevi para o engenheiro encarregado, ele me informou que o alto era o meu sistema nervoso em operação, o baixo, meu sangue circulando. Até que eu morra haverá sons. E eles continuarão depois de minha morte. Não é necessário temer pelo futuro da música.

John Cage, "a figura mais paradoxal de toda a música contemporânea", segundo Umberto Eco, é autor de composições como 4'33", famosa peça cujo título remete à sua duração. Composta em 1952, a peça, que pode ser tocada por qualquer instrumento, é dividida em três movimentos de diferentes durações: 30", 2'23", e 1'40"; no entanto, os intérpretes não tocam nada. A performance prevê que o instrumentista esteja concentrado, que sinalize o final de cada movimento, seja tampando o piano e reabrindo para o próximo movimento, seja virando as páginas em branco da partitura.

Há relatos de que o público que foi assistir à peça foi ficando extremamente incomodado, pois nada acontecia, o pianista que tocava simplesmente não emitiu nenhum som, simplesmente não encostou nas teclas do piano, e tudo o que se ouvia eram os ruídos da plateia, tosses e risos, durante 4 '33".

Não há silêncio que não esteja grávido de som, ${ }^{3}$ diria Augusto de Campos no prefácio à única edição brasileira de escritos de John Cage. Não há aula, principalmente de arte, em que não haja pequenos silêncios como aquela concentração entre o sujeito e a matéria.

O trabalho de John Cage pode ser descrito como uma espécie de poética do silêncio, "reflexo de sua proximidade com uma filosofia espiritual mais voltada para o Oriente que se iniciou em meados da década de 1940, inicialmente com aulas de música indiana com Gita Sarabhai, e com suas leituras do livro A transformação da natureza em arte de Ananda Coomaraswamy filósofo e historiador da arte indiana". ${ }^{4}$

John Cage estudou com Arnold Schoenberg, mediante um contrato do mestre: daria aulas em troca que a vida de Cage fosse destinada à música. Sobre o episódio, Cage relata: "porém

2 CAGE, John. Silence. Middletown: Wesleyan U.P., 1961,. p. 8.

CAMPOS, Augusto. In: CAGE, J. De segunda a um ano: novas conferências e escritos. São Paulo: Ed. Hucitec, 1985. p. 17. prefácio

4 DURÃO. F. Duas formas de se ouvir o silêncio: revisitando 4"33"”. Revista Kriterion vol. 46, no.112, Belo Horizonte, dDezc. 2005

Disponível em: http:// $\leftarrow w w . s c i e l o . b r / s c i e l o . p h p ?$ script=sci_arttext\&pid=S0100-512X2005000200023\&lang $=$ pt $\rightarrow$. Acesso em 26/06/2015. 
depois de ter estudado com ele dois anos, Schoenberg disse: "Para escrever música, você precisa ter sensibilidade para a harmonia." Então ele disse que eu sempre encontraria um obstáculo, que seria como se eu chegasse a um muro pelo qual eu não podia passar. Eu disse: "Nesse caso, vou dedicar minha vida a bater com a cabeça contra esse muro." ${ }^{5}$

Numa breve analogia, é possível pensar que perseguir o silêncio, seja em arte ou em qualquer disciplina, ou melhor, em educação, em geral, talvez seja como pressupor que a harmonia seja o mais importante da música.

Relembro mais uma vez Deleuze e seu desprendimento acerca da figura do professor, que mais do que aquele que exige concentração e atenção ininterrupta, é aquele que aceita e acolhe até aqueles alunos que dormem por anos a fio, pois entende que a sua tarefa é a de movimentar materiais, fomentar o pensamento, e que haverá o momento certo em que cada aluno pegará para si aquilo que the é necessário.

Nesse sentido, o trabalho em arte na educação ocorre no limiar entre silêncios, pequenas epifanias, sempre singulares, de duração variada, em meio à quietude de uma prática de aula de concentração ou no meio do caos de um projeto coletivo.

Ao professor cabe um olhar cuidadoso e atento que busque linhas de fuga para além da lógica imperativa do silêncio como concentração ou negação da aula, pois, assim como na música: ${ }^{6}$

For, when, after convincing oneself ignorantly that sound has, as its clearly defined opposite, silence, that since duration is the only characteristic of sound that is measurable in terms of silence, therefore any valid structure involving sounds and silences should be based, not as occidentally traditional, on frequency, but rightly on duration".

É preciso pensar o silêncio como pequenas durações, como "essas sensações criadoras interiores ou essas contemplações silenciosas", 7 que devem ser o objetivo-limite da aula de arte, uma espécie de caixa de ferramentas que o aluno pode acessar para reconciliar-se com a sua própria quietude, onde pode exercer a sua criação, que por si só escapa a sua territorialização pedagogizante.

Esse é um aspecto do silêncio, visto como oposição ao som; porém, segundo a artista contemporânea Tacita Dean, para quem o silêncio é interesse de pesquisas, ele opera desde os acasos do seu processo de criação. De acordo com a autora, o silêncio aparece como constrangimento, ou melhor, como aquilo que deve ser banido da obra de arte, ou, se pensarmos no caso da educação, deve ser execrado da comunicação.

A artista britânica inicialmente estudou pintura, mas hoje em dia desenvolve trabalhos com diferentes linguagens: vídeo, fotografia, som, além de objetos. Assim como Cage, Tacita, em

\footnotetext{
CAGE, J. De segunda a um ano: novas conferências e escritos. São Paulo: Ed. Hucitec, 1985,. p. 114

CAGE, John,. Silence. Middletown: Wesleyan U.P., 1961,. p. 13.

DELEUZE, Gilles. GUATTARRAI, Félix. O que é a filosofia?, Sznao Paulo: Editora 34, p. 273.
} 
seu trabalho, também se interessa pelo silêncio. A começar pelo seu próprio nome que remete à deusa romana do silêncio.

Dos acasos de percurso, Tacita trabalhou em um projeto sonoro para a rádio BBC, ainda sem ter clareza do que faria. Ao ouvir uma tempestade se aproximando, decidiu pegar seu gravador e captar uma longa sequência sobre vento e granizo. Porém, quando a artista entregou à rádio seu material, eles "se recusaram a transmiti-la porque não havia suficientes pistas narrativas. $O$ problema era o silêncio". ${ }^{8}$ Pouco depois desse projeto, a artista descobriu que esse tipo de tempestade em vocabulário marítimo se chama "tácita".

Parte do processo de criação da artista se dá nos arquivos que ela constitui a partir de objetos encontrados ao acaso - no caso do projeto sobre o silêncio, Tacita tem colecionado há mais de dez anos objetos em que a palavra silêncio aparece escrita.

Tacita Dean tem diversos arquivos caóticos; segundo ela, são maneiras de encontrar sua própria via, desde cartões-postais a palavras como "esperança" e "fé", tais dossiês ganham sentido e se organizam em relação a outras obras, em percursos muitas vezes indeterminados.

O silêncio como espera é também tratado por Tacita Dean, em outros projetos, especialmente em The Green Ray, em que essa ideia é constitutiva da obra. The Green Ray é um filme e cartão-postal que registra o exato momento em que, no pôr-do-sol na linha do horizonte, é possível ver um raio verde no topo da circunferência do Sol: esse fenômeno ótico é raro e dura apenas um segundo. Para Tacita, essa possibilidade de silenciar e observar, de contemplar algo, é da ordem do acontecimento.

Esperar um raio verde, ou um eclipse, enfim, acontecimentos sobre os quais não é possível nenhum controle ou previsão exata, é quase insuportável hoje em dia, quando "a maioria das pessoas não pode suportar a espera; pegam suas coisas e voltam para dentro", diz Tacita. ${ }^{9}$

Talvez somente um exercício próprio do silêncio, como aquele momento de concentração, seja possibilitador do tipo de trabalho dessa artista britânica - uma espécie de encontro com as pequenas epifanias que Caio Fernando Abreu define como as partes "da aprendizagem solitária do não-pedir...", as pequenas epifanias, "miudinhas, quase pífias revelações de Deus feito jóias encravadas no dia-a-dia". ${ }^{10}$

Passando à prática escolar, o pensamento sobre o silêncio dentro dessa modalidade de escuta inspirou uma sequência didática que previa que os alunos pesquisassem com observações cotidianas as qualidades do silêncio que encontravam, na escola, na rua, em casa. Um inventário sobre o silêncio e um repertório corporal das qualidades desse som foram ensaiadas. Qual o espaço para o silêncio na escola, ou, ainda, na sociedade do momento presente, de uma contemporaneidade que busca a ação e a rapidez diuturnamente?

De início, um grande desafio, o recorte - escola já parecia oferecer uma vasta gama

\footnotetext{
8 DEAN, T. IN: OBRIST, H. U. Entrevistas, v.. V.3. Belo Horizonte: Cobogó e Inhotim, 2010,. p. 161-162

$9 \quad$ Idem, p. 170.

10 ABREU, Caio Fernando. Dois ou três almoços, uns silêncios. Fragmentos disso que chamamos de “" minha vida”" (Publicado no jornal "O Estado de S. Paulo", 22/04/1986). Disponível em: http://†www.releituras.com/i_rodrigorosa_ caioabreu_imp.asp $\rightarrow$. Acesso em 01/07/2015.
} 
de questões, talvez porque, na escola, majoritariamente, o silêncio parece, por um lado, uma solução pretensamente capaz de conciliar a autoridade do professor que fala - o especialista -, ao receptor que ouve - o aluno ignorante -, e, por outro, quando o especialista pressupõe o diálogo, o silêncio aparece como um problema - visto que a comunicação pressupõe interação tal como a música precisa da harmonia.

Penso que essas duas formas de visitar o silêncio tanto na música quanto na arte contemporânea, a partir de Cage e Tacita, são pistas perspicazes a serem levadas à sala de aula, seja em forma de inquietação ou de experimentação. Com John Cage, trata-se da impossibilidade do silêncio, haja visto que mesmo no ambiente de maior controle e vedação, o som persiste, e o silêncio de Cage reside justamente em sua condição de escuta. Tacita Dean, por sua vez, apresenta o silêncio como espera ou contemplação. Ambos apresentam em seus escritos e obras uma alternativa de atualização até mesmo daquilo que parece ser banal ou impensado na aula de arte: o silêncio como matéria a ser movimentada, para além da falsa noção de que uma sala "comportada" é uma sala silenciosa - conclusão que, de fato, não costuma significar muita coisa.

O interesse em subverter a ideia de senso-comum do silêncio operacionalizado na educação, não mais visto como aquilo que se espera ou se persegue numa aula, em qualquer uma das disciplinas, mas sobretudo em arte, por causa de seu potencial criador, está na inflexão dos silêncios que coexistem no espaço-tempo de uma aula. Algo como dizia John Cage sobre o objetivo de seu trabalho:

Nossa intenção é a de afirmar esta vida, não de trazer ordem ao caos, nem de sugerir aprimoramentos à criação, mas simplesmente de despertar para a própria vida que estamos vivendo, que é tão excelente, contanto que se coloque a mente e os desejos fora de seu caminho e que se a deixe agir por sua própria vontade.. ${ }^{11}$

Assim, na contramão da contenção, do controle e da rechaça ao barulho típico de uma sala de aula, haja visto que, por vezes, significa uma válvula de escape que possibilita o respiro necessário para prosseguir na escola, estaria um trabalho que se ocupa do banal e do detalhe. Para o qual, não se trata de manter um suposto silêncio, mas de entender que a relação entre professor, aluno e matéria, se faz pela escuta, espera e acolhimentos das pequenas epifanias polifônicas dos muitos silêncios que habitam a sala de aula. 



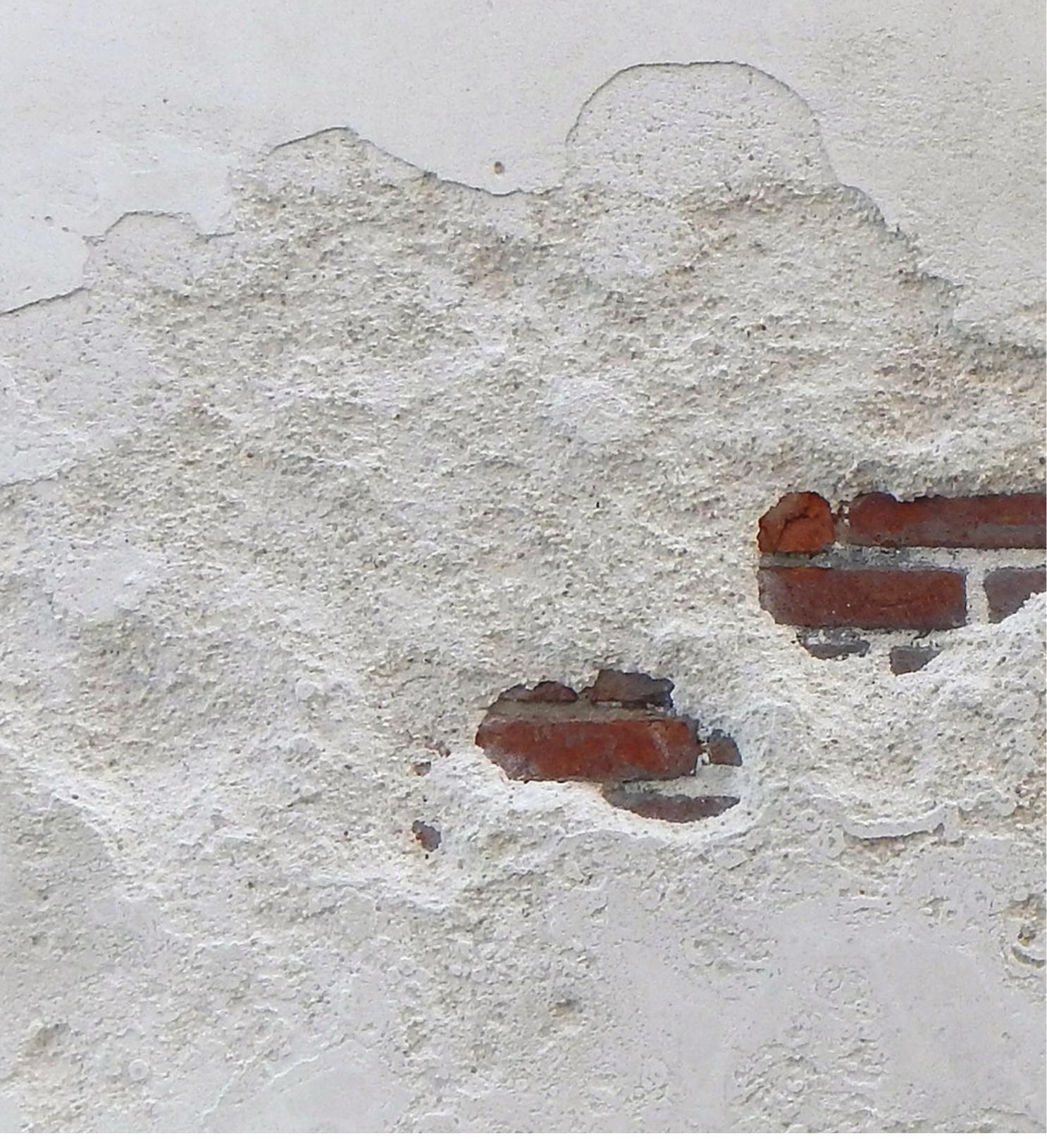


Não são raras as vezes que ouço de meus alunos que a aula de arte tem sim sua importância na escola, e que seu papel está exatamente na possibilidade de cada um se expressar e desenvolver sua criatividade. Contudo, para além desse contexto particular, uma entrevista realizada com mais de 2500 professores de arte aponta que "todos eles mencionaram o desenvolvimento da criatividade como o primeiro objetivo de seu ensino. Para aqueles que enfatizaram as artes visuais, o conceito de criatividade era espontaneidade, autoliberação e originalidade, e eles praticavam o desenho no seu ensino (...)". ${ }^{1}$

Muito se fala em nome da criatividade nas teorias sobre arte-educação, tomando-a tanto como uma premissa de ensino quanto um atributo da arte. Segundo o historiador da arte e filósofo belga Thierry de Duve, há consequências sérias em um projeto de ensino de arte baseado na criatividade: "a primeira é que nada deve restringir o acesso singular aos estudos de arte. A segunda é que imaginamos que a própria arte pode ser ensinada não apenas os meios técnicos da arte. E a terceira é que uma introdução à arte em geral deve preceder qualquer especialização".2

Esse tipo de crença produz um duplo efeito de distanciamento nos alunos, o primeiro é o do próprio fazer, é o "não tenho dom", e o segundo, em relação à arte contemporânea e sua ausência de virtuose e da figura do artista-gênio, a qual os alunos refutam por "parecer simples demais".

Ora, nas premissas apresentadas por Thierry de Duve, encontramos agrupado todo o senso comum em torno da aula de arte, pois se arte é criatividade é porque se trata de uma faculdade intrínseca ao homem e, portanto, de caráter universal. É a partir da criatividade que o "artista" pode se "expressar" e o público pode "entender" sua obra. É também em nome da criatividade como capacidade humana que se deve parte da necessidade de ter a arte na formação dos indivíduos.

Disso advém a força dessa crença, pois ela se funda em uma crença ainda maior - a da ideia de educação como formação. Dessa maneira, o impacto da criatividade na arte é enorme; por mais que se tome como base dados e percepções exclusivas e pessoais, seria possível afirmar que o resultado desse discurso está extremamente enraizado na prática artística escolar, e, ainda que não eu não possa fazer uma análise mais acurada do impacto da noção de arte como criatividade, devo concordar com os Parâmetros Curriculares Nacionais que alegam que o resultado "desta prática indiscriminada de ideias vagas e imprecisas sobre a função da educação artística foi uma descaracterização progressiva da área". ${ }^{3}$ Afinal, o desenvolvimento de criatividade como talento, ou o dom, deveria ser livre e espontâneo.

Na contramão desse tipo de prática, houve a estruturação da disciplina "arte" em torno

BARBOSA, Ana Mae. A imagem no ensino da arte. São Paulo: Perspectiva, 2010,. p. 11

DUVE, Thierry de. Fazendo escola lou refazendo-a?), Chapecó: Argos, 2012,. p. 47

BRASIL. Secretaria de Educação Fundamental. Parâmetros curriculares nacionais : arte / Secretaria de Educação Fundamental. - Brasília : MEC/SEF, 1997.. p. 20. 
de três principais eixos: fazer, apreciar e contextualizar obras de arte, enfocando principalmente a leitura de obras, pois, segundo Ana Mae Barbosa, "o desenvolvimento da capacidade criadora, tão caro aos defensores do que se convencionou chamar de livre expressão (...), também se dá no ato do entendimento, da compreensão, da decodificação das múltiplas significações de uma obra de arte".4

A leitura de obra é, portanto, um tipo de linguagem cuja gramática, essencialmente visual, precisa ser decodificada na aula de arte.

No sentido oposto a essa ideia opera a proposição deleuziana para a compreensão do fenômeno da arte. Menos interessado em identificá-la com objetos prontos, ou como, no caso da arte-educação, com imagens, Deleuze coloca a arte no mesmo patamar da filosofia e da ciência, ou seja, como operações do pensamento - a primeira tem por projeto a criação de conceitos e, a segunda, a criação de funções. Já a arte cria blocos de afectos e perceptos traçados pelas sensações. Ora, o que seriam os afectos e perceptos?

Não são percepções nem afetos coisas próprias dos homens e das lembranças, pois eles são forças que passam pelo homem. São devires que ocorrem também na natureza: a lua, o mar, o deserto são atravessados por blocos de sensações. São inumanos, prescindem do homem, e se sustentam por si próprios.

Uma obra não se mantém se for criada por sensações pessoais do artista, pois ela precisa ser impessoal: "só se atinge o percepto ou o afecto como seres autônomos e suficientes, que não devem mais nada àqueles que os experimentam ou experimentaram". ${ }^{5} \mathrm{O}$ que está em questão, sob esse ponto de vista, são os devires que fazem as sensações vibrarem, que arrancam da matéria o percepto e o afecto. São os campos de trigo de Van Gogh, a Baleia de Graciliano Ramos, o macaco de Kafka, devires que não param de atualizar aquele que sente e o sentido. Não se trata de matéria, "a arte não pensa por imagens, mas por sensações intensas que dão força virtual para a matéria, que não o é".6

Nietzsche também nos auxilia a pensar a arte num espectro um pouco mais amplo do que a ideia de imagem e de gramática visual; ele fala de "arte como espírito inquiridor, frêmito de embriaguez, delírio aventureiro à espreita do novo".7 Com Nietzsche, o poder dionisíaco da arte é vontade de potência, é "o dizer-sim à vida, até mesmo em seus problemas mais estranhos e mais duros, a vontade de vida".

Dessa forma, seja com Nietzsche e sua afirmação da arte como "a grande possibilitadora da vida, a grande aliciadora da vida, a grande estimulante da vida", ${ }^{9}$ seja com Deleuze e Guattari,

BARBOSA, Ana Mae. A imagem no ensino da arte: anos oitenta e novos tempos. Perspectiva: São Paulo, 2009. p. 41. Idem, ibidem, p. 218.

ZORDAN, Paola. “Arte com Nietzsche e Deleuze”. Revista Educação e Realidade,. v. 30. Porto Alegre,: Jul/dez 2005. Disponível em: <http://seer.ufrgs.br/educacaoerealidade/article/view/12472 $\rightarrow$. Acesso em: 20/10/2014. p. 263.

COSTA, Gilcilene Dias da. "Curricularte: experimentações pós-críticas em educação". Revista Educação e

Realidade,. Porto Alegre: v. 36, Porto Alegre, 2011. Disponível em: < http://seer.ufrgs.br/educacaoerealidade/article/ view/11554 $\rightarrow$. Acesso em 03/12/2014. p. 284.

8 NIETZSCHE, Friedich. "Sobre o nascimento da tragédia”. In: Nietzsche - Vida e Oobra. São Paulo: Nova Cultural, 1999, . p. 47.

$9 \quad$ Idem, ibidem,. p. 50 
quando afirmam que sempre se trata de "liberar a vida lá onde ela é prisioneira, ou de tentar fazê-lo num combate incerto". ${ }^{10}$ Ou seja, privilegiando a arte por uma via das potencialidades próprias de um tipo de pensamento - artístico, em detrimento da arte como objeto/produto, necessariamente ancorada na história da arte, geralmente hegemônica.

Nessa mesma linha, Walter Benjamin, em seu célebre texto "A obra de arte na era da reprodutibilidade técnica", apresenta o modo como a modernidade, especialmente o advento da fotografia e do cinema, foram responsáveis pela mudança do estatuto da obra de arte. Não mais identificada por sua aura, tampouco pelo seu valor de culto, a obra de arte foi emancipada do caráter ritualístico em que esteve envolvida até a modernidade justamente pela sua capacidade de ser reproduzida.

Para Benjamin, as consequências desse contexto histórico foram cruciais para o desdobramento da história da arte posterior. Por um lado, a reprodutibilidade possibilitou um maior alcance das obras de arte pelas massas, por outro, ameaçada, reage negativamente em forma de uma "doutrina da 'l'art pour l'art', que é uma teologia da arte. Dela surgiu precisamente uma teologia negativa na forma de uma arte 'pura' que recusa, não só qualquer função social da arte, como também toda a finalidade através de uma determinação concreta". ${ }^{11} \mathrm{~A}$ despeito disso, Benjamin vê na reprodutibilidade da obra de arte um fato inédito na história da humanidade: uma vez destituída de seu valor ritualístico, ela entra para uma nova práxis - a política. Porém, como analisa Benjamin, a estetização da vida política operada pelo fascismo, como tentativa de manter inalterada a propriedade e a manutenção do sistema, obteve inclusive o aval de artistas, especialmente do futurismo, gerando não apenas a estetização da arte, mas, sobretudo, a guerra. Para o pensador alemão, a saída para o comunismo, frente à massificação que tanto o cinema quanto a fotografia inscreveram, seria a politização da arte.

A partir desses três autores, é possível propor uma outra inscrição da arte na escola, sem pretender reforçar a aura perdida daquela obra de arte, tampouco se propor a estetizá-la em produções artísticas de alunos que supostamente devam derivar daquele objeto. Uma saída, especialmente para o ensino médio, está na politização da aula de arte, como aquele momento em que são apresentadas ideias, obras que falem daquele povo que não existe, de Klee, ou seja, obras cuja tarefa é a de "suscitar determinada indagação num tempo ainda não maduro para que se receba plena resposta". ${ }^{12}$

Dessa maneira, para além da ideia de releitura ou de imagem no ensino da arte, está a noção de proposições transcriadas e transcriadoras, operações estas cingidas pelas concepções de arte a partir do viés apresentado. 0 objetivo central dessa proposta é indagar sobre o que faz ranger o senso comum no qual a arte é facilmente assimilada no contexto escolar, ou seja, fazer pensar através de procedimentos artísticos, refletindo sobre o modo como a arte pode reposicionar questões para além de sua estetização.

10 DELEUZE, Gilles. GUATTARI, Félix. 0 que é a filosofia?. São Paulo: Editora 34, 2010, p. 222

11 BENJAMIN, Walter. "Magia e técnica, arte e política: Ensaios sobre literatura e história da cultura”. Obras Eescolhidas. trad. Sérgio Paulo Rouanet. São Paulo: Brasiliense, 1994,. p. 171.

12 Idem, ibidem. 
A ideia de transcriação é uma excelente aliada para uma outra inscrição da arte no âmbito da escola. Tal noção parte da ideia de tradução constituída durante toda a trajetória do poeta e tradutor Haroldo de Campos. Alguns neologismos foram criados por ele e por seu grupo (Noingandres, formado por Haroldo, Augusto de Campos e Décio Pignatari, no final da década de 1950) na tentativa de dar conta dessa experiência de tradução baseada na insatisfação com uma ideia "naturalizada": "ligada aos pressupostos ideológicos de restituição da verdade (fidelidade) e literalidade (subserviência da tradução a um presumido 'significado transcendental' do original) - ideia que subjaz a definições usuais, mais 'neutras' (tradução 'literal'), ou mais pejorativas (tradução 'servil')".13

Pode-se notar que uma preocupação central ocupou os escritos sobre tradução de Haroldo de Campos desde seus textos iniciais: a de conectar à teoria do linguista Roman Jakobson o pensamento sobre tradução "metafísica" de Walter Benjamin.

A teoria benjaminiana, a grosso modo, é uma investida em libertar a língua pura, desvelando-a no modus operandi do texto. "Ou seja, o tradutor constrói paralelamente (paramorficamente) ao original o texto de sua transcriação, depois de 'desconstruir' esse original num primeiro momento metalinguístico". ${ }^{14}$ Dessa forma, trata-se de operar no intracódigo, como o denomina Campos, que, ao ser extraditado, pode migrar de uma língua para outra.

Assim, o trabalho da tradução com Benjamin consiste em uma espécie de traição ao original e a aura que supostamente compete às obras de arte, desprivilegiando a ideia de "autenticidade" e "autoridade", "o tradutor é um leitor-autor, no extremo um 'traidor' ou usurpador". ${ }^{15}$

A passagem do texto para sua função seria algo como passar da ideia de tradução como transposição intertextual para lhe fornecer um emprego extratextual (entendido em função de seus usos e contextos históricos).

A tradução, seguindo o trilho proposto, opera o que Jakosbon chama de "transposição criativa", Benjamin, de "transpoetização" e, por fim, Haroldo de Campos chamará de "transcriação", todos com o objetivo comum de conferir ao ato de tradução aquilo que dele não pode ser separado - a criação.

Levar obras de arte para a sala de aula para serem decodificadas e depois traduzidas em forma de uma releitura seria um gesto que vai na contramão da potencialidade que a obra apresenta ao seu tradutor-primeiro, o professor, que é quem seleciona o que vai traduzir e o porquê vai fazê-lo. Além disso, alerta Campos, sobre a dificuldade que reside em qualquer tentativa de tradução de uma obra de arte, devido a sua "fragilidade estética"16 - informação estética que não pode ser codificada senão conforme o que o próprio artista já o fez, sendo ela inseparável de sua realização. Com isso, Haroldo de Campos afirma a impossibilidade da tradução da obra de arte, tendo em vista que esse ato se configura como a criação de uma nova informação estética. Essa

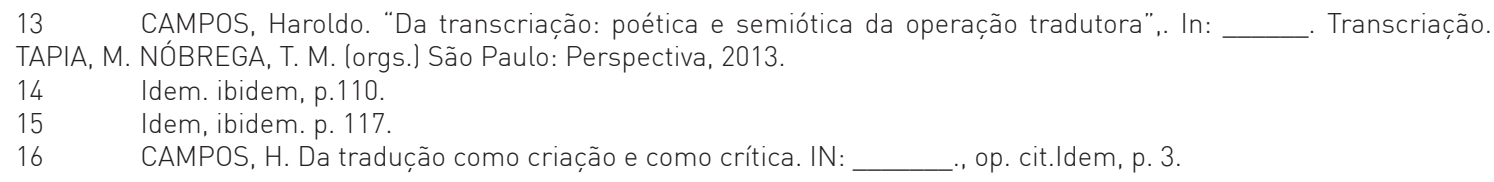


ideia prepara sua noção de tradução como criação, e, ao mesmo tempo, vai de encontro à tese deleuziana sobre a incomunicabilidade da arte, ao pegar de empréstimo uma fala de Paul Klee sobre fazer arte para um povo que não existe, para dizer da impossibilidade da arte comunicar, pois sua operação passa pela criação de afectos e perceptos, e não pela linguagem.

No entanto, a tradução de uma obra de arte como transcriação mantém um vínculo de isomorfia com a obra, faz-se autônoma e paralela, porém recíproca. Corazza, a esse respeito, diz: "A tradução é, dessa maneira, um ato político, que desfuncionaliza línguas instrumentais e aproxima distâncias, num processo de transformação cultural. Em seus atos de traduzir, opera como meio, que desestabiliza o próprio status quo da linguagem educacional". ${ }^{17}$

Portanto, o professor de arte não mais interessado em operar pela tradução servil, seja de conteúdos de história da arte, seja por meio de técnicas artísticas, consciente de sua posição de tradutor dos afectos e perceptos que são inundados pela arte, não mais privilegiará traduzir intertextualmente a obra de arte, pois terá se dado conta da ficcionalidade da obra pura, da inatualidade da ideia de aura da obra de arte, e partirá, consequentemente, para uma desconstrução dessa concepção de arte no interior de sua própria aula.

Ao invés de operar pela chave da criatividade, propõe-se a ideia de criação didática, que se ocupa da arte, tanto daquela institucionalizada, quanto da operação do pensamento no sentido deleuziano, sem criar hierarquia entre elas. Ao usar elementos de ambos os conceitos como disparador de seu mais importante processo em sala de aula, o professor faz da aula um campo de experimentação, lugar de devires reais e desterriotorializações afirmativas.

Frases do tipo "Essa aula parece aula de sociologia ou filosofia" causam estranhamentos, fissuras no lugar comum do pensamento e da disciplina "arte", pois o interesse não está no conteúdo externo e estanque, mas no movimento do pensamento que ele causa, nas fissuras, nas normas concebidas e estabelecidas, no estremecimento das certezas.

Assim, a principal matéria para a aula de arte, entendida como esse campo largo de experimentação, é a própria vida, "promovida por encontros com formas de conteúdos e de expressão do mundo". ${ }^{18}$ Dessa maneira, a transcriação torna-se o procedimento diário da aula de arte, visto que não importa ao professor de arte reconstituir ou decodificar nenhuma informação semântica ou qualquer servilidade ou fidedignidade ao tema, pois não se trata de fazer uma tradução decalcada da obra de arte ou de uma suposta verdade conceitual acerca do tema. Muito pelo contrário, essa prática é feita de movimentos, de transcriações artísticas, de acordo com um ato ético-estético-político.

Não mais obrigado a transmitir conteúdos originais, e assim desmistificando a própria arte, não canoniza o original, cola Picasso com Antônio Poteiro, Foucault com youtube, Arnaldo Antunes com desenho no corpo, fazendo pular acordes de Gauguin. Tudo isso pois está pouco interessado em "o que o artista quis dizer", daí a falta de compreensão da ideia comumente aceita nas aulas de arte de releitura. Tudo o que se faz na aula de arte é "trans" e criação, já que 
"tudo o que não invento é falso", como dizia Manoel de Barros.

Isso não quer dizer que o professor, como transcriador, não se ocupará dos originais ou mesmo do passado em detrimento de um fluido presente. Referencia-se o tempo todo às suas fontes, faz-se diálogo franco e crítico com elas, presentificando-se o passado e trazendo-o com sua atualidade, visto que não há conteúdo que não traga consigo algo necessário para se pensar a vida e o mundo, revitalizando o momento num vai-e-vem entre passado e presente, e conferindo, assim, o sentido do conteúdo e sua qualificação na disciplina "arte", de modo a romper no entanto, as relações casualmente aceitas entre formas e conteúdos.

Para operar transcriadoramente, o professor precisa autorizar-se a selecionar o que tem de mais importante, "elementos filosóficos, artísticos e científicos do seu tempo e espaço; 'irreverência temática', para privilegiar elementos, obras e autores". ${ }^{19}$ Oriunda dessa mistura de elementos, autores e obras que se cria em educação e pode-se ultrapassar os limites da própria disciplina, configurando-se como resposta ao estranhamento inicial sobre o que era aquilo: aula de arte/sociologia. Hoje, para meus alunos do Ensino Médio, "a arte é muito mais do que desenho, a arte pode mudar o meu jeito de ver e pensar o mundo e a sociedade". ${ }^{20}$

$19 \quad$ Idem, ibidem, p. 216.

20 Resposta de uma aluna do $3^{\circ}$ ano do EM 



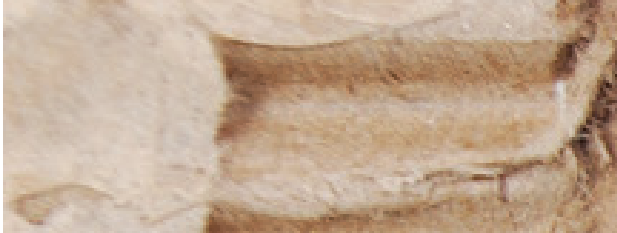

iar 


\section{Uma estética da docência}

"O que devemos aprender com os artistas?", a questão postulada por Nietzsche em A gaia ciência no aforismo $299^{1}$ tem me perseguido tanto em minha prática de sala de aula quanto no exercício de pesquisadora.

O que significa aprender com os artistas? Ou, ainda, o que, de fato, ensinamos quando apresentamos artistas na sala de aula? Para o filósofo alemão, é preciso afastarmo-nos "das coisas até que não mais vejamos muita coisa delas e nosso olhar tenha de lhes juntar para vêlas ainda ou ver as coisas de soslaio e como que em recorte ou dispô-las de forma tal que elas encubram parcialmente umas às outras e permitam somente vislumbres em perspectivas ou contemplá-las por um vidro colorido ou à luz do poente ou dotá-las de pele e superfície que não tenha completa transparência: tudo isso devemos aprender com os artistas". ${ }^{2}$

Certamente, a visão parcial e não totalizante do artista promoveria o que Nietzsche chama de "distância artística" das coisas e das pessoas. Seria esse distanciamento que o artista tem com o mundo o elemento que nos permitiria examinarmos nossas vidas sob uma dada perspectiva, a ponto de podermos rir e chorar de nós mesmos, a fim de tornarmo-nos "os poetas - os autores de nossas vidas, principiando pelas coisas mínimas e cotidianas". ${ }^{3}$ Assim, seria uma espécie de aprender com os artistas a "artistar" as nossas vidas; segundo o filósofo, trata-se de uma tarefa que o próprio artista não cumpre por completo, pois ele deposita a criação em seu trabalho e não vê sua vida como uma obra.

Tornarmo-nos poetas e autores de nossas vidas é uma maneira de não perdermos a capacidade de criar, de se criar em contraposição à falsa ideia de retidão; "a questão é que não nos deixemos dominar pela vontade de verdade, pela ansiedade em atingir as essências das coisas". ${ }^{4}$ Mas, de que modo, em educação, tem-se pensado a partir dessa perspectiva?

Ainda hoje, parece que não aprendemos essa lição, tendo em vista que, ao menos no campo da educação, a despeito dos discursos em torno da autonomia e cidadania - que aparecem como valores máximos a ser perseguidos - pouco espaço encontramos para que modos de vida sejam criados, uma vez que cabe à pedagogia transmitir conhecimento e elevar o sujeito, dotando-o de capacidades que ele não têm, valores e modelos morais, ou seja, prega-se que "verdades" sejam ensinadas. De acordo com o pensador Luís Fuganti, "Essa forma racional de conhecer e esse modo moral de se conduzir tornam-se suportes de uma suposta autonomia formal, constitutiva do lugar de autoridade, autorizada e autorizante, que fariam das forças mais nobres da vida função de valores de progresso, desenvolvimento e aperfeiçoamento." ${ }^{5}$

A educação, pelo menos desde o início da modernidade, tem estado vinculada a

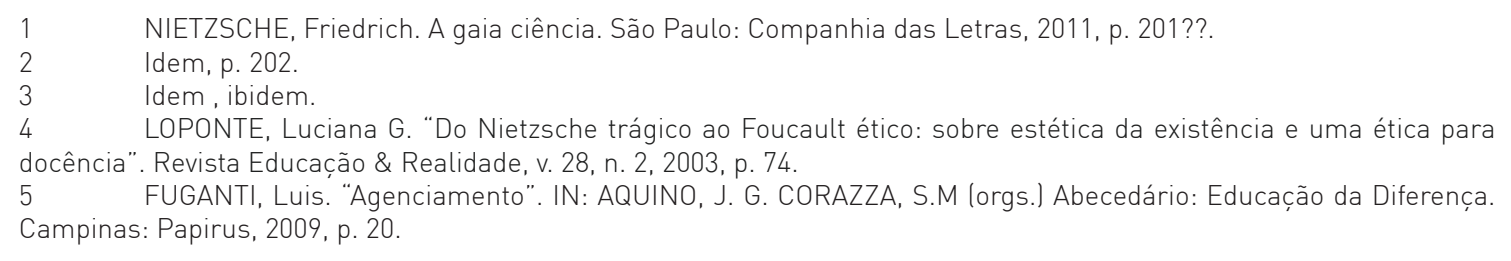


esse tipo de discurso hegemônico. Nesse sentido, para o pensador francês Michel Foucault, os discursos pedagógicos, assim como a religião, a psicanálise e as instituições em geral funcionam como uma espécie de autoridade sobre as maneiras de fazer, compondo modos de vida regidos por relações de poder. Nesse ponto reside o interesse do pensador francês em destrinchar, de maneira genealógica, as formas sobre as quais o sujeito pode ser o que é.

Pode-se dizer que a temática em torno do sujeito e da verdade ocupou toda a obra de Michel Foucault, que, em diferentes momentos, a cercou e analisou os contornos que ela poderia ter, como em As palavras e as coisas, obra em que o pensador verifica de que modo o sujeito vai se constituindo nos discursos científicos como indivíduo falante e trabalhador. Seja pelas análise das formas de coerção, como na psiquiatria e nas prisões, tratava-se de buscar as formas de veridicção que possibilitavam a existência de determinados sujeitos, sem, contudo, pretender homogeneizá-los. Foucault nos alerta em sua obra sobre a generalização do sujeito que pode recair sobre uma espécie de teoria do sujeito dada a priori. Ao contrário de uma fenomenologia do sujeito, ou de tomá-lo como uma substância, o filósofo se debruça sobre as práticas de jogos da verdade que historicamente constituem tais sujeitos.

Em sua fase final, Foucault se endereça às práticas do cuidado de si localizadas nas sociedades greco-romanas; ele as analisa como formas de ser - exercício de si que configura um modo de se estar no mundo. Quanto a esse aspecto, Foucault, em seu método genealógico, verifica que, para os gregos, o domínio de si era indispensável para o exercício da liberdade. Sendo "a ética a forma refletida assumida pela liberdade". ${ }^{6}$ Desta forma, prossegue o pensador:

O cuidado de si é certamente o conhecimento de si - este é o lado socrático-platônico -, mas é também o conhecimento de um certo número de regras de conduta ou de princípios que são simultaneamente verdades e prescrições. Cuidar de si é se munir dessas verdades: nesse caso a ética se liga ao jogo da verdade. ${ }^{7}$

O interesse de Foucault em destrinchar as relações do sujeito com a verdade não aponta, de maneira alguma, um retorno ao modo de vida greco-romano, também "não expressa nenhuma convocação a um retorno metafísico ao estilo de vida antigo, mas uma possibilidade estratégica de interpelação dos atuais modos de subjetivação".

Assim, o cuidado de si ao qual se refere Foucault diz respeito a um modo de vida ético, e se inscreve, portanto, numa espécie de ontologia do presente, na possibilidade de constituir-se um ethos filosófico.

Disso deriva seu interesse na psicagogia grega como prática estóica do exercício da liberdade - forma de conduzir o outro -, e a ela opõe-se a ideia de pedagogia como transmissão

6 FOUCAULT, Michel. "A ética do cuidado de si como prática da liberdade". In: Ditos \& Escritos V - Ética, Sexualidade, Política. Rio de Janeiro: Forense Universitária, 2004, p. 268.

$7 \quad$ Idem, ibidem.

8 AQUINO, Julio G. "A escrita como modo de vida: conexões e desdobramentos educacionais". Revista Educação e Pesquisa, v. 37, n. 3, p. 641-656, 2011. p. 644 
da verdade. A psicagogia envolve o cuidado de si como transformação de si, e tal transformação não diz respeito a uma esfera privada da vida, pois visa o cuidado com o outro, a partir de uma "construção voluntária, laboriosa e permanente de uma posição ética diante do mundo, posição ancorada no princípio de que, "entre si e si mesmo, abre-se a distância de uma obra de vida a ser realizada". 9

Em sua obra final, fica claro que o projeto foucaultiano se remete ao passado com uma preocupação clara apontando para o presente, numa "ontologia da atualidade", cujo propósito estaria em buscar bases para constituir uma estética da existência, como aquela experiência limítrofe de transformação de si - "aquele que busca inventar-se a si mesmo". ${ }^{10}$ É ainda, em oposição à moral que "se apresenta como um conjunto de regras coercitivas de um tipo especial, que consiste em julgar ações e intenções referindo-os a valores transcendentais (é certo, é errado....". ${ }^{11}$

Nesse sentido, ainda que por clivagens distintas, tanto Nietzsche quanto Foucault se ocupam do desenvolvimento de uma atitude frente à vida propondo "um trabalho de nós sobre nós mesmos enquanto seres livres", ${ }^{12}$ uma estética da existência, como diz Foucault: "me surpreende, em nossa sociedade, que a arte se relacione apenas com objetos e não com indivíduos ou a vida; e quem também seja um domínio especializado, um domínio de peritos, que são os artistas". ${ }^{13}$ De maneira que, além de operar nas fronteiras entre o que se é e o que se pode ser, essa atitude estética perante a vida é também de caráter experimental, pois é capaz de ser crítica aos discursos totalizantes e radicais buscando uma visão singular, contingente e parcial, que possibilite tanto a crítica do que nós somos como a ultrapassagem dos limites que nos constituem.

No entanto, essa reivindicação em torno de uma autoria perante a própria vida, não apenas ocupou os estóicos, Nietzsche ou Foucault. Essa ideia ocupou também toda uma geração de artistas (1960/70), claramente preocupados com uma possível fusão entre arte e vida, cuja utopia era a de que a arte pudesse fundar um outro tipo de experiência - não mais associada ao simulacro ou à elevação das aparências do mundo, mas como projeto ético capaz de modelar a experiência tanto política quanto estética dentro da própria vida.

Não muito diferente do que diria Nietzsche, para quem a arte seria o componente que traz a embriaguez, a desorganização e o antídoto para a vida. Também não distante do que, para Deleuze e Guattari, seria a arte: "trata-se sempre de liberar a vida lá onde ela é prisioneira, ou de tentar fazê-lo num combate incerto". ${ }^{14}$ Podemos, assim, perceber que há uma confluência entre a filosofia da diferença e práticas artísticas contemporâneas, o que confirmaria a tese de Deleuze

9 GROS, Frédéric. apud AQUINO, J., op. cit.Idem, p. 645.

10 FOUCAULT, Michel. "O que são as luzes? Ditos e escritos", Arqueologia das ciências e história dos sistemas de pensamento. MOTTA, Manoel Barros da (Org.). Rio de Janeiro: Forense Universitária, 2000 .v. 2, p. 335-351, 2000. p. 344.

11 DELEUZE, Gilles. Conversações: 1972-1990. São Paulo: Editora 34, 1992. p. 125.

12 FOUCAULT, Michel. op. cit. p. 348.

13 FOUCAULT, Michel. apud. PINHO, Luis Celso, A vida como uma obra de arte: esboço para uma ética foucaultiana Disponível em: $\leftarrow$ www.ufrj.br/graduacao/prodocencia/publicacoes/etica-alteridade/artigos/Luiz_celso_Pinho.pdf $\rightarrow$ Acesso em 01/08/2015.

14 DELeuZE, G. GuATTARI, F. O que é a filosofia?, São Paulo: Editora 34, 1992. p. 222 
e Guattari de que arte e filosofia seriam operações muito próximas do pensamento. Ambas trabalham com criação, sendo a primeira por meio de afectos e perceptos, e a segunda, por meio de conceptos. Os afectos e perceptos movimentados pela arte como blocos de sensações que são arrancados das matérias são devires que fazem a matéria vibrar, pois, para eles, a arte não trabalha por imagens; uma arte que se sustente de pé prescinde do comentário e da imagem, ela arranca sensações e nos afeta.

Reformulando a nossa questão de fundo: 0 que podemos aprender com esse tipo de arte? Ou seja, o que significaria operar com a arte a partir desse enfoque?

Também a arte-educação parece interessada nessa questão. Ana Mae Barbosa, em um artigo chamado "A arte-educação precisa dos artistas", de 1984, aponta para a importância dos artistas para o ensino da arte. A pesquisadora diagnostica que "há um generalizado alheamento do artista em relação à criança, em relação à arte na escola, à arte na educação". ${ }^{15} \mathrm{E}$, como medida reparatória desse desvio, ela convoca os artistas a se juntarem aos educadores para, "numa ação conjunta, tentar através da educação pública uma melhor distribuição do patrimônio artístico, da riqueza estética, elevando a qualidade de vida da população". ${ }^{16}$

Observamos aqui que, na perspectiva apresentada por Ana Mae, são os artistas que devem se aproximar da educação e ensinar os alunos e professores, e não o contrário. Há também o entendimento de que a arte que os artistas devem partilhar na educação é a arte capaz de, ao tornar acessível os códigos culturais eruditos, elevar a condição de vida do povo. A forma como o artista lograria nesse objetivo seria através do convencimento e esclarecimento em torno de sua obra: "preparar o público para aceitação de uma nova estética". ${ }^{17}$

Contudo, a ideia de que o trabalho do artista na educação, circulando presencialmente ou não na sala de arte, tem como intuito oferecer a compreensão de seus trabalhos e da aceitação da estética que ele propõe, seja pela via da história da arte, seja pela via do fazer artístico ancorado na apresentação desses artistas, não parece considerar, por exemplo, o processo histórico de desestetização desencadeado pela arte moderna, tendo na geração de 1960/70 a sua concretização .

Helio Oiticica foi um dos artistas interessados em romper com as barreiras entre as linguagens, saindo, num primeiro momento, da pintura e partindo para as proposições de participação social constitutivas de suas obras. O projeto dessa geração previa não apenas a superação da arte, mas, sobretudo, sua inserção no cotidiano, de forma que o espaço da arte para Oiticica não devia ser a galeria ou o museu. Sua célebre frase resume tal ideia: "O museu é o mundo; é a experiência cotidiana". ${ }^{18}$

A "antiarte" de Helio Oiticica previa a participação do espectador, deixando o mundo da contemplação para tornar-se uma experimentação cujo objetivo seria a "completação da

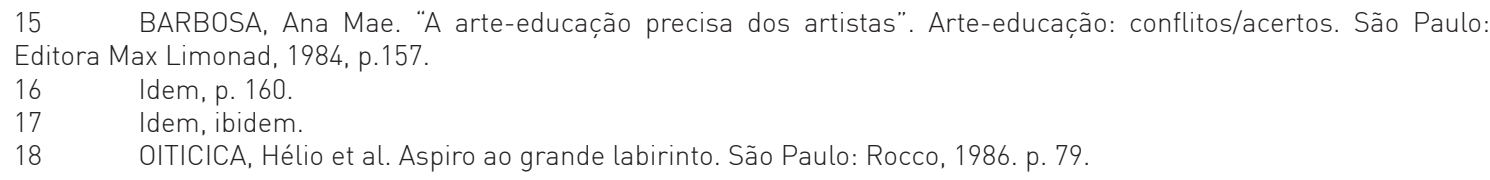


necessidade coletiva de criação latente". ${ }^{19}$ Oiticica e sua geração estavam interessados em uma prática que pudesse remodelar a experiência, focando nos comportamentos e nas atitudes. Pode-se dizer que o programa de Oiticica, além de coerente, tinha um caráter ético, pois "não pretende estabelecer uma 'nova moral' ou coisa semelhante, mas derrubar 'todas as morais', pois que estas tendem a um conformismo estagnante". ${ }^{20}$ Ao contrário disso, estaria a proposição de uma antiarte como sensações de arte, com a proposição de um "campo experimental de vivências descondicionantes, um 'contexto para o comportamento, para a vida".". ${ }^{21}$

Tanto Oiticica como sua geração pretendem, em consonância com a questão postulada por Foucault, ${ }^{22}$ operar nas fronteiras e brechas da arte, embaraçando os limites entre estética e fruição, propondo outros modos de se relacionar com a arte.

Assim, na esteira do que pretendia Foucault em sua obra final, estão os artistas dessa geração e seus herdeiros "contemporâneos", cujo interesse está na atitude estética que passa a prescindir das obras, modelando "a experiência, agindo sobre nossas estruturas perceptivas, formando esquemas de olhar". ${ }^{23}$

Diante dessa "desestetização do estético", de uma arte que não apresenta obra, e que não nos oferece estruturas codificadas, parece residir a indiferença que esse tipo de atitude artística encontra na sala de aula. E se, ao contrário do consensual, ao invés de transformarmos a arte em simulacros, cópias e conteúdos estáticos, à luz das experiências artísticas da geração descrita e, junto com Nietzsche e Foucault, propuséssemos que a própria aula tivesse uma finalidade estética, de forma que a própria prática docente se configurasse em uma estética de vida? Mais do que transformar esse tipo de experimentação em conteúdos cristalizados na sala de aula, nós professores, especialmente de artes, deveríamos aprender com os artistas a inventar à nós mesmos, a não nos conformarmos com o que somos, desconfiando das verdades instituídas, em busca de compor com nossos alunos uma experiência, no sentido foucaultiano, em busca da construção de uma ética a partir da experiência estética que a arte possibilita. De que forma a arte pode afetar tanto o professor quanto o aluno na sala de aula? Por afeto, entendemos, junto a Spinoza, aquilo "pelas quais sua potência de agir é aumentada ou diminuída, estimulada ou refreada". 24

Talvez, preocupados em conceber a aula como uma atitude estética, para além da obra de arte e que, pudéssemos operar por um tratamento dado à arte, não como um conteúdo fechado apresentado por meio de artistas e do "convencimento" das estéticas por eles propostos, tampouco através de uma estilística em torno do artistas, mas, sobretudo, a partir da problematização que acompanha esse tipo de arte, algo em torno de uma remodelagem

\footnotetext{
$19 \quad$ Idem, ibidem

Idem, p. 81.

FAVARETTO, Celso. “Deslocamentos: entre a arte e a vida". Revista ARS, São Paulo, v. 9, n. 18, p. 94-109, 2011. p. 101.

"Não poderia a vida de todos se transformar em uma obra de arte?". IN: LOPONTE, Luciana Gruppelli. ARTE E ESTÉTICA DA DOCÊNCIA: CONVERSAS COM NIETZSCHE E FOUCAULT. Disponível em: http://www.portalanpedsul.com. br/admin/uploads/2008/Educacao_e_arte/Trabalho/01_39_55_ARTE_E_ESTETICA_DA_DOCENCIA_CONVERSAS_COM_ NIETZSCHE_E_FOUCA.pdf. Acesso em 20/08/2015. p. 1.

23 FAVARETTO, Celso., op. cit. p. 107.

24 SPINOZA, Benedictus. Ética/Spinoza. Belo Horizonte: Autêntica Editora, 2007, p. 50.
} 
da nossa percepção e ação diante do mundo. Artístico no sentido nietzschiano, como aquela atitude em relação à vida. O que significaria que todo o conteúdo oriundo da vida e do mundo, seja das crianças e adolescentes ou do adulto, são catalisadores para atitudes artísticas que ultrapassem a sala de aula e que transbordem no cotidiano escolar, fazendo florescer a diferença e o impensado.

Seria algo como uma estética da docência que foge dos modelos já prontos, que sabe sua responsabilidade ética com a investigação intelectual, criando fissuras no interior dos discursos dominantes e cristalizados da educação, através da reflexão sobre si e sobre os jogos de verdades imbricados nas relações pedagógicas, oferecendo ali um espaço de resistência, um respiro. Não obstante, uma estética da docência "não implica, então, pensar em uma docência idealizada, surgida de forma cristalina e límpida". 25

Com Paul Valéry, pensar uma aula de arte que pudesse "substituir as artes por uma arte de viver" ${ }^{\prime \prime}$, ou seja, que nos ocupemos menos com conteúdos estáticos, formais, históricos etc., e passemos a entender a aula de arte como uma experimentação de modos de vida no espaço escolar.

É claro que essa aula deve ser respaldada por práticas artísticas de diferentes épocas e movimentos artísticos, mas o foco central precisa passar pela construção ética e estética de si - do professor. Também é preciso trabalhar na modelagem de modos de vida, transformando o potencial da arte, da criação de afectos, perceptos ${ }^{27}$ e, sobretudo, de um tipo de operação do pensamento, capaz de movimentar matérias, aliando-se a uma educação do desejo, entendendo, afinal, novamente com Foucault, que o desejo é aquilo que permanece impensado "no coração do pensamento". ${ }^{28}$

Operar com essas companhias é buscar uma educação, cujo elemento principal é o pensamento - e não a busca por respostas corretas às perguntas estabelecidas, pois isso é da ordem da representação. Pensar é tarefa de criação, é travar lutas entre sentidos, buscar aquilo que está do seu lado exterior.

A tarefa educacional de uma vida-docente como obra de arte seria, portanto, da ordem do estranhamento, e não da conformação e da identificação. Um rasgo no caos, uma fissura como possibilidade do novo, do intempestivo. Deleuze diria que a tarefa do professor é a de ajudar os estudantes a se reconciliar com sua solidão. Solidão esta que, face aos imperativos da comunicação, parece cada vez mais inatingível. Essa tarefa seria a de ajudar-nos e ajudálos (os alunos) a aprender e a inventar-se a si o tempo todo, como quem pode, diante da vida, embelezá-la, colocar-se como poetas, para quem o principal ensinamento advindo da filosofia, e à espreita de Foucault, seria, por um lado, ter uma "atitude crítica" diante da vida em nome da

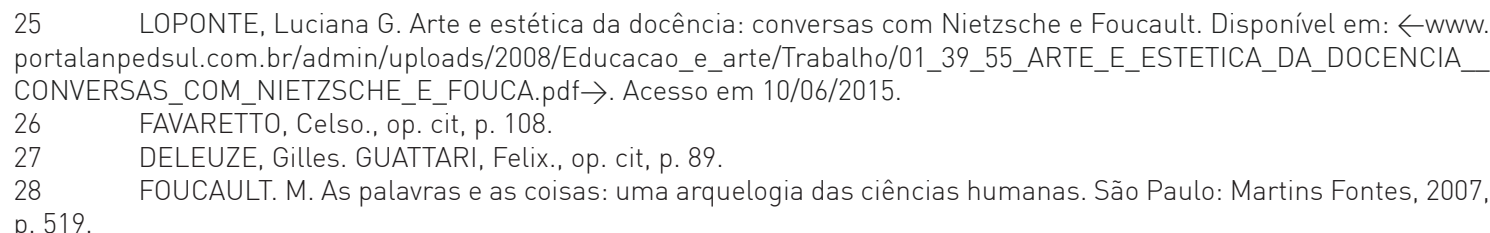


qual seria possível "não ser governado assim, por isso, em nome disso, vista de tais objetivos e por meio de tais procedimentos." ${ }^{29}$ E por outro lado, visa-se uma atitude estética, como descreve Lygia Clark, mais uma artista preocupada em incitar-nos "pela experiência, a tomar consciência da alienação em que vive,"30 cujo objetivo era (é) que possamos atingir um "estado de arte sem arte", resgatando uma potência criadora de si, afastando-se da alienação apresentada pela artista.

Não se trata, no entanto, de pensar em transformar a docência em uma obra-prima, no sentido das Belas-Artes. Ao contrário, parte-se da ideia de arte trazida por Nietzsche, Deleuze e Foucault, ou seja, uma "arte que se assume como esboço, como rascunho contínuo, como busca de estilo, como experimentação, como resultado árduo e quase infinito do artista sobre $\mathrm{si}^{\prime \prime} ; 31$ uma arte que seja motriz de uma docência que, ao mesmo tempo em que se exerce, se experimenta, se (re)inventa e, fundamentalmente, se vê num plano de construção ética, estética - e, mais do que pedagógico, político -, atuando na diferença, sem pretender acabar com ela, mas problematizando o consenso e as ideias prontas por meio de devires, gestos e inscrições no mundo feitas de potência. Em suma, essa arte em questão possibilitaria o exercício de outras relações de poder no interior da aula mantendo, principalmente, uma atitude crítica de si e do outro - da relação pedagógica -, a fim de experimentar em si e com os outros diferentes modos de ser.

Resta saber se, nós, professores (de arte ou não), estamos prontos para abandonar as imagens pré-fabricadas do competente, do respeitado, do professor cristalizado em estereótipos disseminados em livros didáticos, professores que acreditam que seu curso e seu conteúdo representam "a verdade", e são incapazes de inflexionar os discursos, numa postura afirmativa diante dos desafios da vida docente, tendo em vista que essa atitude possibilita a reinvenção de um espaço político na educação como prática da liberdade.

29 FOUCAULT, Michel. O que é crítica?[Crítica e Aufklärung]. Disponível em: $\leftarrow$ www.filoesco.unb. br/Foucault $\rightarrow$ Espaço Michel Foucault, p. 4.

30 CLARK, Lygia. Nós recusamos. Texto escrito em 1966. Disponível em: http://www.lygiaclark.org.br/arquivo_ detPT.asp? idarquivo=24, acesso: 03/11/2014.

31 LOPONTE, Luciana., op. cit.. p. 7 
$\rightarrow y^{3} \mathrm{x}^{\circ} \cdot 4=$ $2 \rightarrow 1, \quad 120$

$\rightarrow 1{ }^{2} \rightarrow 1-2 \leq$

1. $2>0.1 .2$

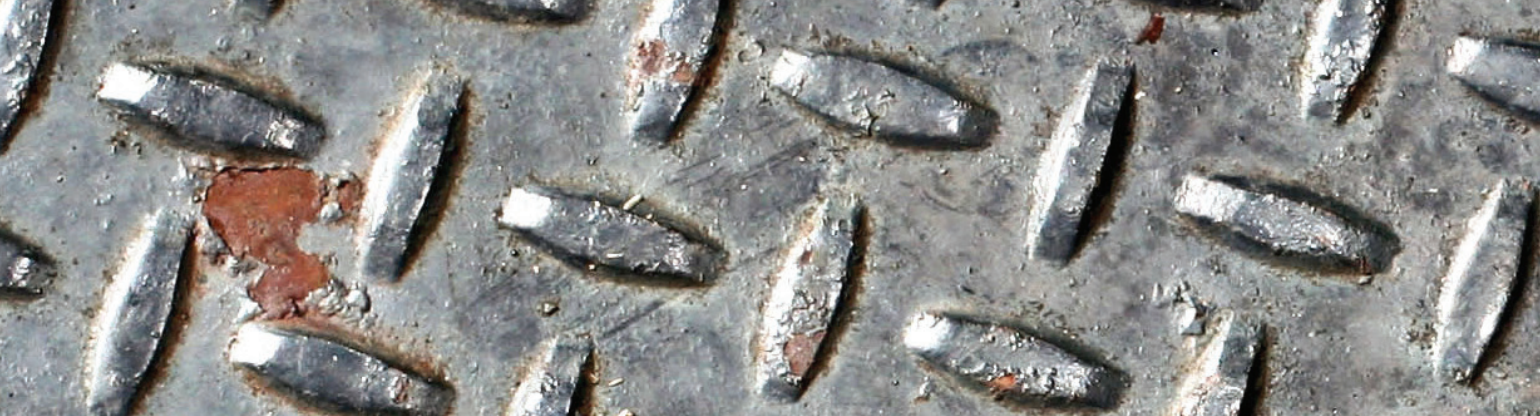

4 in

()

l.

$\rightarrow y_{1}^{\infty} \underbrace{\infty}_{1}$

$-\infty$

$y^{2}-\infty \rightarrow 19$

$1=2>1$

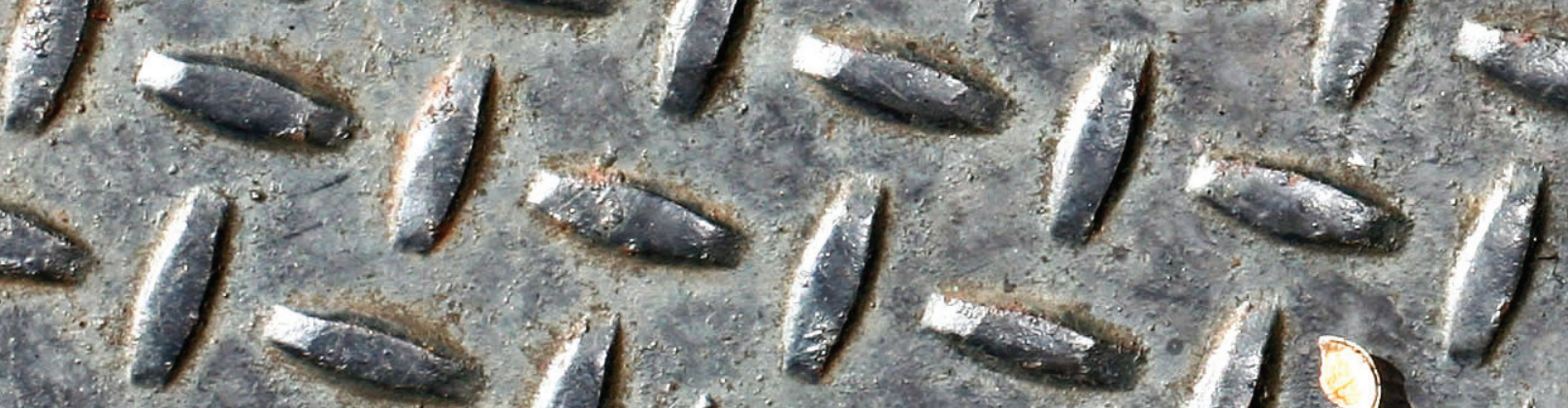

$y \rightarrow 1 \rightarrow 1$

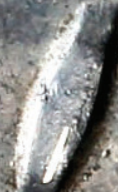

19 


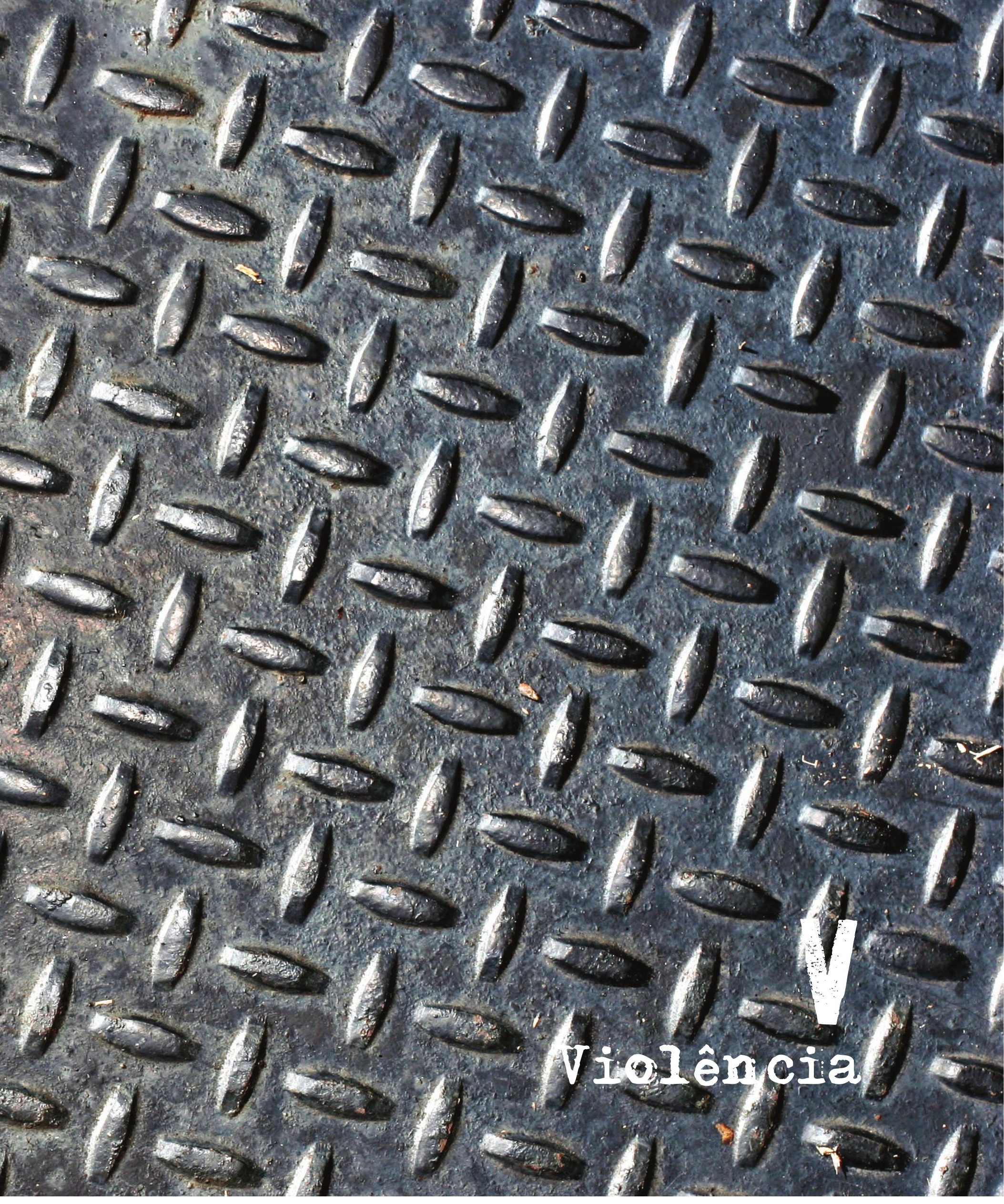



Marcelão, 17 anos, quer ser lutador de UFC, come oito claras de ovo no intervalo e vem para a aula de Arte. Paulinho, 16 anos, menino tímido, tem osteogênese congênita. É pequeno e se enturma com os demais meninos na "lógica da zueira". Celão brinca de amarrar Paulinho, com uma corda pega no meu armário e sem a minha permissão, em um dos pilares da escola. A brincadeira rende muitas risadas de todos os que estão em volta. Ao me verem, correm, desamarram Paulinho e a partir daí começa um caloroso semestre de aulas, cujo foco estava na intervenção artística como forma de manifestação política.

$\mathrm{O}$ que te indigna? foi o mote do que se transformou o plano de ensino anual que previa entre outras coisas, pintura, história da arte, xilogravura etc. Uma sequência inicial partiu da indignação que esse tipo de brincadeira me causou. Gerou discussão, enfrentamento, dissonâncias. Aquela aula de arte com espaço de aprofundamento em especificidades das artes visuais desapareceu e com ela uma professora menos atenta às questões pulsantes do grupo.

Paralelamente, o desconforto que essa atitude me causou fez com que eu tivesse necessidade de pautar a questão da violência também no grupo de professores de toda a escola. Junto a outros dois amigos professores organizamos uma reunião cujo tema seria a "violência simbólica". Normalmente burocráticas e recheadas de discursos pedagogicamente corretos, as reuniões da Escola de Aplicação têm poucos momentos de discussão pautada nas dificuldades e reflexões dos próprios educadores. No geral, parte-se de um problema - que está sempre no aluno - e discute-se do alto da sabedoria que o professor se autoconfere.

Nossa proposta, no entanto, já de início era diferente-usamos diferentes registros: fílmico, quadrinhos, texto literário e filosófico - e ousada, pois a partir desses materiais propusemos uma auto-reflexão sobre de que maneira a violência simbólica atravessa nossas aulas e de que forma o uso da autoridade de professor corrobora para a criação de situações silenciosas de violência.

Esse questionamento se pautava na noção desenvolvida pelo sociólogo francês Pierre Bourdieu, para quem a violência simbólica diz respeito às relações de poder entre dominado e dominador, cuja aceitação das regras perpetua a condição de ambos. Para o pensador, a escola é um lugar de exercício de violência simbólica dado que a escolha de conteúdos, currículos, programas e etc. é exercício de poder das classes dominantes que inculcam nas classes dominadas valores aceitos como "naturais".

Ainda que não tenhamos nos atido à problematização em torno da escola - como o pensador o faz em "A reprodução" -, a ideia de dominação, naturalização e situações silenciosas onde há algum tipo de abuso de poder, gerou, por si só, grande desconforto por parte dos professores.

O exercício proposto era simples: a partir desse conceito, da análise do texto de Walter Benjamin "Experiência" - cuja crítica centra-se na ideia de que o acúmulo de experiência como propriedade do velho pode desqualificar o próprio da juventude - sua curiosa vivacidade, além do excerto do filme Amarcord (1973), de Federico Fellini, no qual é feito uma caricatura dos diferentes tipos de professor de uma instituição de ensino italiana, deveríamos em pequenos 
grupos pensar sobre quais seriam nossas supostas caricaturas e como elas condiziam com nossas ações em sala.

O resultado não foi totalmente atingido visto que houve uma enorme resistência por parte do grupo de professores em, primeiro entender que a proposta dizia respeito à problematização das nossas práticas e em segundo, pela recusa em fazer uma autocrítica, o que me faz pensar que esse tipo de abordagem (tão elementar) não tenha espaço naquela instituição e quiçá na maioria delas, pois o que parece valer como uma suposta objetividade é a relação aluno - conhecimento sem colocar-se em reque. A figura do professor como mestre/especialista prescinde de análise critica.

Já no cotidiano da aula de arte foram precisos seis meses para que a inflexão ocorrida no curso surtisse efeito positivo, pois o incômodo com "essa aula de arte que parece aula de sociologia"1, sempre aparecia em forma de estranhamento nas falas de alguns alunos. Muita discussão, provocação e alguns trabalhos muito potentes resultaram desse episódio.

A indignação foi o que faltava para dar esse impulso em direção a uma arte de reflexão e contestação social. A naturalização da noção de brincadeira no discurso de todos acerca do menino amarrado no pilar foi o disparador. Senti necessidade de pesquisar de onde poderiam vir essas referências que autorizavam práticas violentas como "brincadeira". Me lembrei que meses antes havia circulado na mídia o caso do "marginal" preso por "cidadãos de bem" a um poste - aclamado por figuras formadoras de opinião como Datena e Rachel Sheherazade. Outra referência possível estava também nas notícias veiculadas na época sobre trotes universitários de calouros presos em postes. Juntei a esse repertório, programas de entretenimento que usam desse tipo de humor para sacanear-se entre si, como Pânico e Legendários.

A partir dessa primeira aproximação, elenquei artistas que trabalhavam com corda, amarrando-se ou propondo esse tipo de experiência para o público. Selecionei uma entrevista com a artista paraense Berna Reale, na qual ela fala que seu trabalho é sempre sobre uma espécie de violência silenciosa a qual estamos sujeitos coletivamente e que naturalizada aparece como parte do cotidiano.

Juntamos todos os alunos do $2^{\circ}$ ano do Ensino Médio no auditório para passar uma sequência de vídeos e imagens que abririam o tema. O primeiro, a opinião expressa pela exâncora do jornal do SBT, Rachel Sheherazade, sobre o "marginalzinho" preso ao poste, causou uma catarse coletiva, os alunos pareciam estar assistindo a uma piada extremamente engraçada. Esperamos eles se acalmarem e passamos um episódio do Pânico na TV, no qual um dos atores pede um chá quente e toma uma xícara de água quente com dez pimentas dedo-de-moça amassadas dentro. Todos riram tanto quanto na notícia do SBT. No entanto, o próximo slide trazia informações sobre este ator, que passou quatro dias hospitalizado, por ter contraído uma úlcera, fruto daquela "brincadeira".

A discussão girou em torno do que os faz rir, por quê uma notícia pretensamente jornalísticas causa reações cômicas, o que pode ser engraçado numa pseudo-brincadeira que leva um ator ao hospital. Isso para tentar chegar a uma suposta ética das brincadeiras entre esses alunos. 
Não atingimos o objetivo central, não descobri o que move esse tipo de brincadeira, mas pude perceber muita coisa sobre as relações instituídas entre a escola e essa turma. Há uma espécie de enfrentamento declarado. Essa turma é aquele famoso caso de fracasso escolar, há nela cerca de quinze alunos de uma retenção massiva feita três anos antes. Pouca abertura de diálogo, eles persistiram em se manter numa postura defensiva através da agressão verbal, inclusive a ponto de não conseguirem entender que não se tratava para nós, professoras de arte, de dar um sermão de cidadania e valores supremos. Ao contrário, queríamos entender como as imagens e vídeos que apresentamos poderiam se relacionar com uma brincadeira como aquela de amarrar um colega mais fraco num pilar da escola, em suma, queríamos entender como funcionava a tal da "zueira".

Dali para frente, eu com os meus alunos - que desta série do Ensino Médio são apenas dezoito, pois nosso projeto para esse ciclo propõe que a modalidade artística a ser cursada nos três anos do EM é de escolha dos alunos - nos colocamos frente às questões que nos indignavam, transformando-as em intervenções artísticas pela escola.

As primeiras intervenções foram fruto de provocações contidas em frases do material educativo da 29a. Bienal de São Paulo: "Por que calar?", "Quando não há nada o que vemos?", "O que acontece cada vez que você consente?" e "O que permanece invisível no seu dia-a-dia?".

Cada grupo tratou de alguma problemática do seu cotidiano que causasse indignação em resposta à pergunta do seu grupo, materiais e intervenções de acordo com suas propostas. As referências visuais iam compondo a aula na medida em que eram necessárias conforme o projeto de cada grupo ia se delineando. Eu apresentava trabalhos que poderiam tecer alguma relação com a proposição dos grupos.

O resultado desse primeiro trabalho foi muito importante, inclusive, para se estabelecer uma relação de cumplicidade, pois, muitos deles optaram por manter-se anônimos, e juntos fomos mapeando os efeitos do trabalho no cotidiano da escola. Temas como racismo (dado que na escola há uma parcela considerável de alunos negros), gênero e violência consentida no ambiente escolar foram atacados.

No entanto, faltavam elementos nesses trabalhos que me impulsionaram às propostas seguintes. Todos os trabalhos eram muito escolarizados, em forma de cartazes, canetinhas, etc., sentia falta tanto de qualidade estética nos trabalhos quanto de intervenção no espaço coletivamente. Partimos para os flashmobs. Ao invés de grupinhos, éramos um coletivo. Foi desafiador, pois eles não se sentiam seguros em propor e muito menos em ser o centro de alguma atividade. Assistimos a inúmeros flashmobs e criamos duas propostas, uma era reanactment de uma ação sobre lixo. Na escola há muito lixo sobre os pátios, principalmente, depois dos intervalos.

A proposta foi deixar, propositalmente, duas garrafas de plástico no chão próximas às lixeiras e quando algum aluno as colocasse no lixo seria aclamado com uma salva de palmas. 0 grupo estava convicto que não daria certo, que ninguém pegaria aquelas garrafas. Foi preciso dois intervalos completos, mudança de estratégias, para que alguém pegasse essas garrafas. Além disso, em discussão sobre algo mais autoral, mais condizente com a escola, criamos a proposta de brincadeiras da infância a serem experimentadas durante os intervalos, incluindo os alunos 
desavisados do restante da escola. Durante um intervalo de alunos do Ensino Fundamental II, meus alunos corriam e "pegavam" alunos, simulando um pega-pega, ou então faziam uma ciranda, dando a mão para alguém desconhecido.

Essas e outras experiências foram desafiadoras, primeiro para vencer a barreira do lugarcomum do qual os alunos relutam em sair, depois para superar a timidez e ojeriza de se expor e ser alvo de críticas. Eu havia conseguido, minimamente, operar com a noção de coletivo, mas o refinamento estético e a desescolarização das propostas ainda não haviam sido atacadas. Partimos então para a etapa de fazer o museu ser a escola - parafraseando Oiticica, artista que nos serviu de disparador para pensar interferências no espaço escolar.

Nada de caneta e papel, no lugar disso, tecidos, bexigas, barbantes, fitas de isolamento, cones, e o que cada proposta pedisse. O nosso limite de material seria tudo aquilo que poderíamos arrumar. A proposição girava em torno da ideia de público participador. Pois, até aquele momento, as intervenções aconteciam em esferas que previam espectadores - ainda que nos flashmobs contássemos com algumas participações restritas aos amigos já prevenidos. Espectadores tais - os alunos do EFII - que mais estranhavam do que aderiam. Agora era preciso envolver os alunos de forma que não fosse possível se eximir de participar.

A questão já esboçada da crise hídrica da cidade de São Paulo foi o mote de um grupo que se utilizou de um tecido de cerca de dez metros em vários tons de azul para "inundar" a entrada do prédio de aulas do Ensino Médio. Amarrado na ponta de uma das torneiras e se espalhando por todo piso desse hall, sem nenhum cartaz ou explicação, este trabalho causou um grande alvoroço e diferentes interações. As reações foram sendo captadas por fotos e olhares, desde professores receosos de pisar naquele tecido, alunos em rodinhas tentando entender o que seria aquilo, ou participações inesperadas como a do aluno que decidiu nadar sobre o tecido.

Um outro grupo decidiu propor uma outra forma de passar pelas escadas deste bloco, amarrando barbantes entre ela, obrigando que as pessoas passassem entre os fios para poder descer ou subir. Outra intervenção aconteceu na entrada da cantina, onde foi instalada uma cortina com mais de cinquenta bexigas que exigia a interação de quem a quisesse transpor.

Essas proposições, que partiram do menino amarrado, da indignação para uma ocupação artística do cotidiano e do espaço escolar, me fazem reafirmar que há possibilidades efervescentes de inscrever a arte no cotidiano escolar, que não passe por um processo de "conteudização" dos procedimentos artísticos, mas pela sua evidenciação na prática diária, corroborando para uma infestação lenta e contagiante feitas de brechas e pequenas epifanias no dia a dia, capazes de inscrever a experiência no sentido foucaultiano: "transformar a existência cotidiana numa espécie de laboratório de possibilidades que tenha como meta última o embelezamento da vida". ${ }^{2}$

2 PINHO, LUIZ. A vida como uma obra de arte: esboço para uma ética foucaultiana.. In: http://www.ufrrj.br/ graduacao/prodocencia/publicacoes/etica-alteridade/artigos/Luiz_celso_Pinho.pdf. Acesso em 09/03/2015 



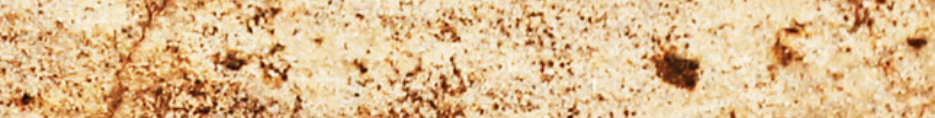

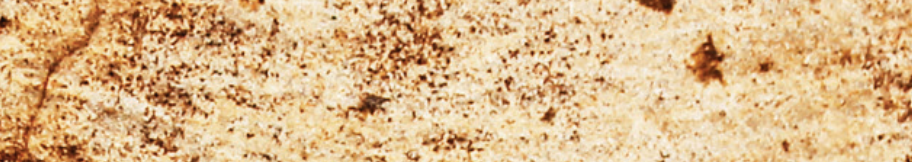

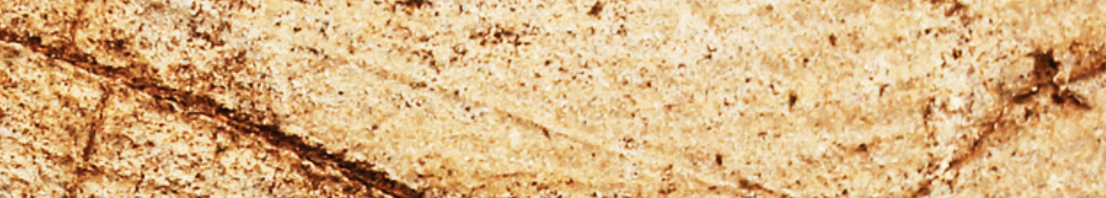

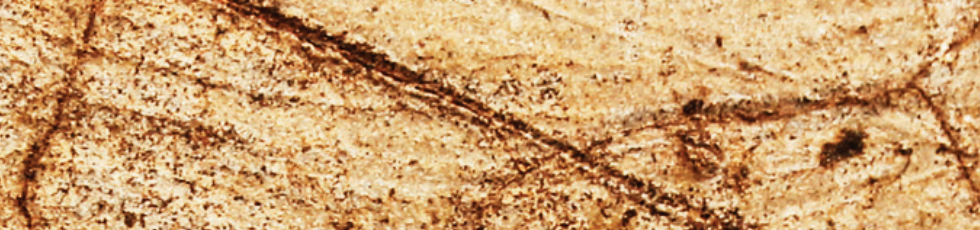

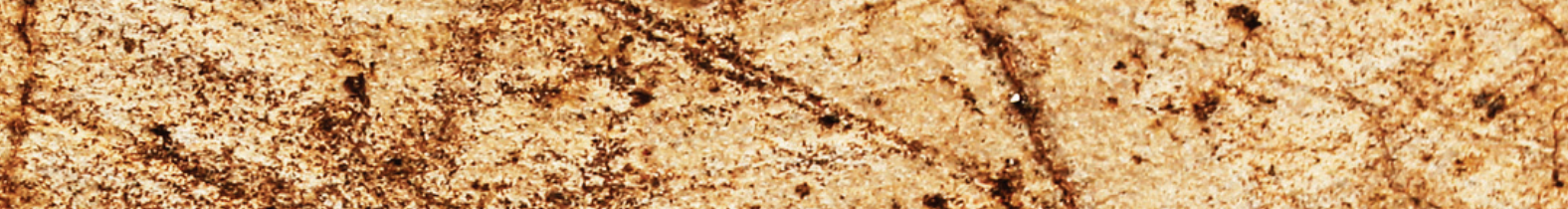

7.

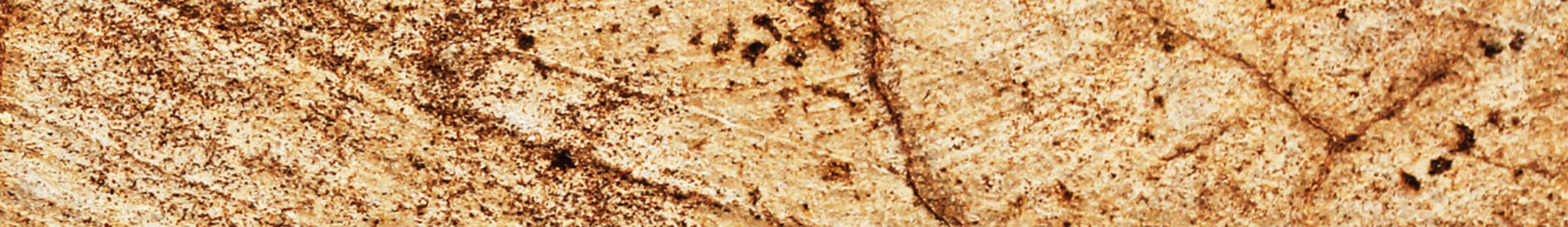

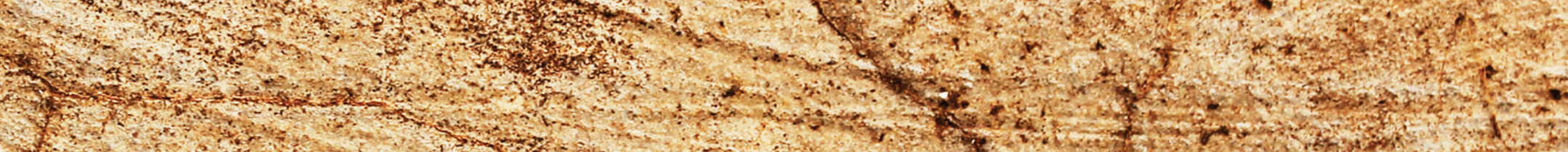
2.

$t^{3}$

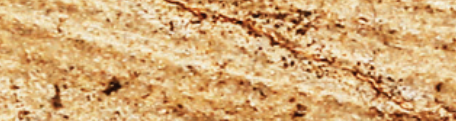
$3=0$

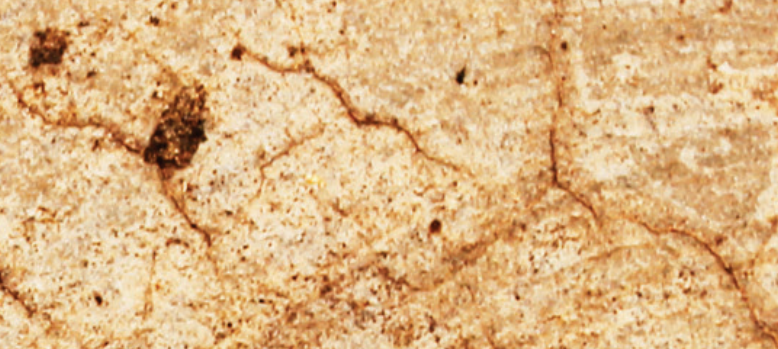

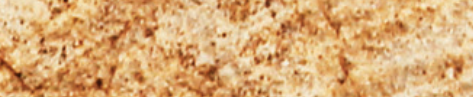

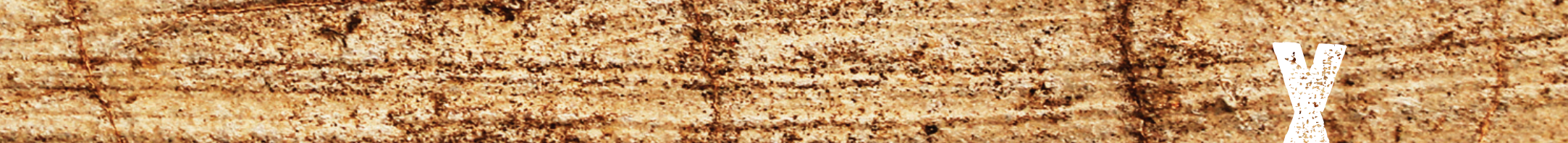

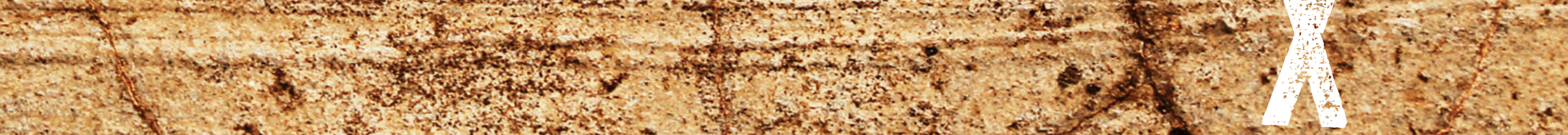

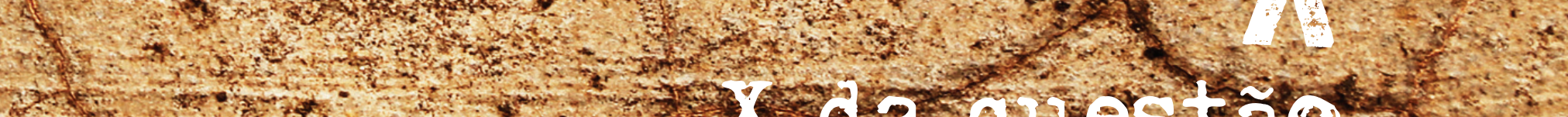

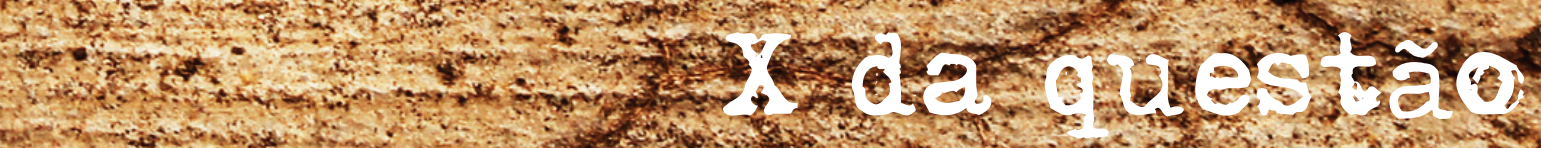
S.

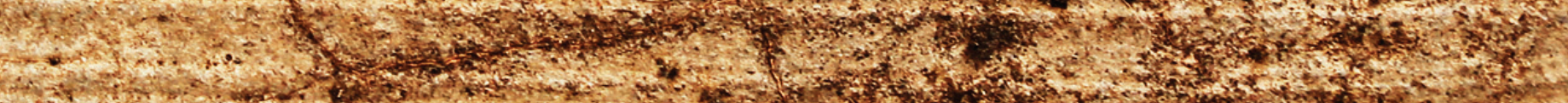



Educação artística, arte e educação, educação através da arte, Arte-/Educação, nomenclaturas que revelam o desejo de inscrever a arte na educação, cada qual com sua vertente e suas especificidades. Para a pesquisadora Carmen Biasoli, no final do século XX, era possível afirmar que, visto a miscelânea de vertentes entre os termos, "a educação artística nas escolas não vai nada bem"1, para ela o que se vê é uma "pulverização de tópicos de técnicas(...) que empobrecem o verdadeiro sentido do ensino da arte". ${ }^{2}$

A busca por esse sentido do ensino da arte parece ser premissa das pesquisas na área. Ana Mae Barbosa, afirma em 1991 que "para que as décadas futuras sejam mais promissoras para a arte-educação, é necessário, primeiro romper com o preconceito de que a arte-educação significa apenas arte para crianças e adolescentes e afirmar arte-educação como investigação dos modos como se aprende arte na escola". 3

Eis a questão: como se aprende arte na escola? Talvez o diagnóstico um tanto pessimista de Carmen Biasoli se deva ao que afirmam as pesquisadoras Fusari e Ferraz: "muitos professores propõem atividades às vezes totalmente desvinculadas de um verdadeiro saber artístico". ${ }^{4}$ Nos caberia uma digressão, na contramão da proposição de Ana Mae, e da afirmação de Ferraz e Fusari, ao invés de pensar como se aprende arte seria preciso se pensar se há "um verdadeiro saber da arte", que na afirmação acima aparece como um dado. Se o verdadeiro saber artístico é um dado, como a arte-educação tem lidado com ele?

Muito se fala em nome de um saber da arte, mas de acordo com o pesquisador Cayo Honorato, o ensino da arte, "por vezes, pressupõe ou promove uma relação mais ou menos imediata entre arte e educação, seja ao modo de uma junção ou de um pertencimento recíproco, talvez por recear a desterritorialização em que seria lançado, caso assumisse essa inconformidade". ${ }^{5}$

Afinal, como inscrever a arte na educação sem pretender com isso restringi-la em um determinado conceito, conteúdo ou fórmula? Não se trata, ao procurar por um saber próprio da arte, de circunscrevê-la em um determinado conceito. Não se trata, tampouco, de reivindicar uma suposta autonomia da arte, o que facilmente nos faria cair na armadilha de caracterizá-la. Mas, sobretudo, busca-se entender, primeiro, se há um saber específico da arte, e segundo, quais movimentos são feitos entre arte e educação a partir deste saber.

A noção de "saber da arte" aparece no notável texto do crítico Ronaldo Brito chamado O moderno e o contemporâneo, de 1980. Para Brito, a passagem da modernidade para a contemporaneidade é a pedra de toque para o entendimento das práticas não só atuais, como também de um regime de significação interno da arte. Não mais entendida como Belas-Artes -

1 BIASOLI, Carmen Lúcia Abadie. A formação do professor de arte: Do ensaio...à encenação. Campinas: SP Papirus, 1999. p. 86.

$2 \quad$ Idem, ibidem.

BARBOSA, Ana Mae; Sales, Heloisa Margarido. 0 ensino da arte e sua história. São Paulo: MAC/USP, 1990. p. 7

FERRAZ, Maria Heloisa C. de T.; FUSARI, Maria Felisminda de R. e. Arte na Educação Escolar. São Paulo: Cortez, 1992. p. 20

5 HONORATO, Cayo. A formação do artista. p. 26. 
dividida em linguagens e gêneros -, mas como apresenta Thierry de Duve, a "arte em geral", pela sua possibilidade de tornar qualquer arte, traz à tona uma discussão que extrapola aquilo que, comumente, é apresentado na escola.

Poder fazer arte com tudo que há disponível nos posiciona diante de uma rede discursiva que, por um lado, apresenta um saber que institui e legitima o que é arte, e por outro, um sistema de práticas artísticas que operam o colapso do primeiro. É nas vanguardas modernas, em suas rupturas em relação aos suportes tradicionais, que vemos a insurgência de duas forças que corroboram para a constituição da arte contemporânea: uma primeira, que configura uma espécie de academicismo de vanguarda - manutenção de uma tradição dentro das vanguardas. E uma segunda, que representa uma quebra de pacto entre o que se instituía como arte.

Ronaldo Brito nos fala que ao se afastar do estatuto que the fora durante séculos conferido - cópia do real, comprovando uma unidade do olhar vinculada aos tradicionais meios com os quais ela operava -, localizada na modernidade, vemos uma primeira disparidade entre a arte e sua institucionalização.

Ainda com Ronaldo Brito, como uma espécie de golpe, a arte moderna fere a si própria para salvar-se, numa tentativa de separar-se do estatuto que a vinculava ao belo, à unidade e à tradição, e ao mesmo tempo reivindicar para si o que the era próprio, fazendo tensionar aquilo que parecia unitário, uma espécie de "insuspeitada distinção" entre o valor e o produto da arte. Pode-se dizer que trata-se de uma disjunção, mas que obviamente uma faz parte da outra, sem serem coincidentes. Seria "dessa diferença, [que] passa às vezes sob silêncio, [que] a arte moderna tirou sua força de emergência(...), pois "as linguagens da arte, subitamente evidenciou-se, não criavam o próprio valor. Este era construído, fabricado, pela estrutura burocrático-ideológica que as cercavam". 6

Como nos fala De Duve, essa tradição foi incorporada pela modernidade sob a forma por ele chamada de academicismo de vanguarda e herdamos disso a sensação de que tudo e qualquer coisa pode ser arte. Fazendo uma analogia com uma anedota, Duve nos diz que assim como o rei, o artista passa a transformar tudo o que toca em ouro. Certamente, este legado advém do trabalho de embate trazido não apenas por Duchamp e a invenção do readymade, mas também - seguindo com um exemplo de Ronaldo Brito - por Picasso, para além da leitura cooptada pelo sistema da arte, que transforma em conteúdo, toma seus traços mais superficiais e formais institucionalizando-o.

Tanto Picasso quanto também a Pop Art representam um esforço desmedido de resistência à institucionalização do sistema da arte, o primeiro em contraposição ao regime de representação de toda a história da pintura, o segundo numa ácida crítica à figuração, um "cinismo corrosivo", demonstrando uma "aguçada consciência reflexiva sobre a materialidade da arte". 7 Intensificado na década de 1960, o saber da arte procurou se pronunciar em diversos discursos de artistas. Donald Judd, por exemplo, com seus objetos específicos, discorre sobre

\footnotetext{
6 BRITO, Ronaldo. O moderno e o contemporâneo (O novo e o outro novo). In: BASBAUM, R. (org.) Arte contemporânea brasileira: texturas, dicções, ficções, estratégias. Rio de Janeiro: Rios Ambiciosos, 2001. p. 204.

$7 \quad$ Idem, ibidem.
} 
uma nova produção que não cessa de extrapolar tanto a pintura quanto a escultura mas que não tem em comum nada a não ser o fato de não se tratarem de objetos comuns, mas sim objetos específicos. Enquanto Kaprow tenta fugir à cooptação institucional com sua antiarte.

Os exemplos acima apontam para a existência de um funcionamento e de uma racionalidade próprios que o saber da arte produz, insistindo em operar por brechas e fendas na rede discursiva criada em torno da arte, e que gera um efeito na arte contemporânea - não é preciso muito esforço para compreender, de um apanhado de discursos em torno da pluralidade, isto pois, "the dominating art discourse identifies art with the art market and remains blind to any art that is produced and distributed by any mechanism other than the market". ${ }^{8}$ Todavia, seria ingênuo, pois, afirmar que toda arte contemporânea se faça sob um regime de oposição absoluta ao modo de produção capitalista", seria o mesmo que considerar que o saber da arte é "completely powerless, lacking any immanent criteria of choice and immanent logic of development". 10

A discussão é complexa, pois esses procedimentos, essas "manobras de estranhamento", como as descreve Ronaldo Brito, parecem não estar em jogo na construção discursiva da arteeducação, primeiro por pouco se debruçar sobre as especificidades do contemporâneo, e segundo por categorizar a arte - e quanto a isso vale para qualquer momento histórico, a Arteeducação "resumida assim a uma cronologia empírica, esquece, prefere esquecer, a luta que se trava no campo simbólico para tratá-lo como espaço neutro, contínuo e indiferenciado". ${ }^{11}$

Nesse ponto, vale retomar a afirmação de Fusari e Ferraz, pois apesar de apresentarem algum reconhecimento da questão, não é feito qualquer aprofundamento que opere com o saber da arte, ao contrário, no seu desenvolvimento a desconsideração daquele saber vai sendo reiterada como, por exemplo: "o que se nota, então, é um afastamento dos princípios mínimos de norteiam um ideário artístico, cultural e social," 12 sem contudo definir minimamente quais seriam tais ideais, assim como quando afirmam que o ensino de arte deve atender a uma "mobilidade conceitual" da arte, sendo por elas elencada em consonância às metanarrativas trazidas nesta pesquisa: "arte como técnica, materiais artísticos, lazer, processo intuitivo, liberação de impulsos reprimidos, expressão, linguagem, comunicação..". ${ }^{13}$

Nota-se, portanto, que a arte-educação pouco se endereça ao saber produzido pelo trabalho de arte, e assim, prefere trabalhar com aquilo que Brito chamou de "estrutura de códigos vigentes de inteligibilidade", ou seja, prefere operar a partir de estruturas que não levam em consideração a criação como um processo imprevisível, como já apresentou Duchamp e tantos outros artistas. Assim, é possível perceber que a

art education is situated in a field of contradiction between the freedom

GROYS, Boris. Art power. p.6.

BRITO, Ronaldo., op. cit. p. 206.

GROYS, Boris., op. cit. p.6.

BRITO, Ronaldo. "Pós, Pré, Quase ou Anti?". p. 5.

FERRAZ, Maria Heloisa C. de T.; FUSARI, Maria Felisminda de R. e. Arte na Educação Escolar. p. 20

Idem. ibidem. 
of aesthetic work and the task-directed work of institutions in general and expectations surrounding schools in particular. No wonder that in recent years art education as a technical operation has become the norm. This has led to a narrowing of artistic content, even when 'successful' and 'viable.'14

Contudo, referências ao saber da arte como as apresentadas por Fusari e Ferraz aparecem com alguma insistência em textos da área, e que no geral, quando reconhecem tal afastamento, buscam uma (re)unificação entre arte e arte-educação. Como nos apresenta Honorato, "chama a atenção que alguns desses textos tragam como título expressões ou questões que sugerem uma separação entre arte e educação (momentos em que esses campos se entreolham de lugares diferentes), mas também uma vontade de ligação. São eles: "Devolvendo arte à arte- educação" (1984) de Vincent Lanier, "A arte-educação precisa dos artistas" (1984) de Ana Mae Barbosa, e "O que pode a educação aprender das artes sobre a prática da educação?" (2002) de Elliot Eisner". ${ }^{15} \mathrm{~A}$ amostra selecionada por Honorato é pequena porém precisa, a partir da análise dos textos feita pelo autor é possível perceber que todos parecem convergir no que diz respeito ao endereçamento que fazem ao saber da arte, semelhante ao apresentado por Fusari e Ferraz com pouco aprofundamento de questões inscritas na constituição discursiva da própria arte, e assumindo um papel de saber sobre arte desvinculado dos demais saberes do sistema.

Por fim, percebe-se que a arte-educação elege nas suas curvas de enunciação e de visibilidade operar a partir de uma suposta "mobilidade conceitual" à revelia do saber da arte e do sistema da arte, praticando uma espécie de esquizofrenia consensual cujos objetivos parecem estar claramente para além do campo da arte.

Por fim, como poderíamos pensar uma arte na educação que levasse de fato em consideração o saber da arte? 




$$
\text { F. }
$$

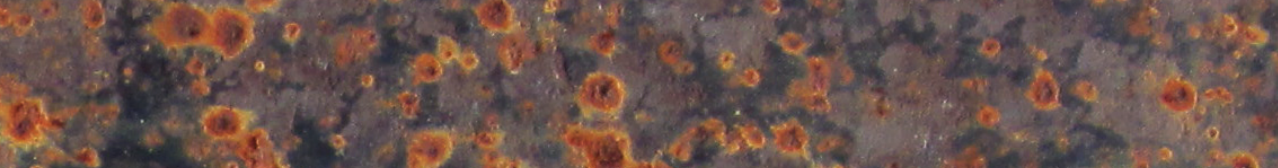

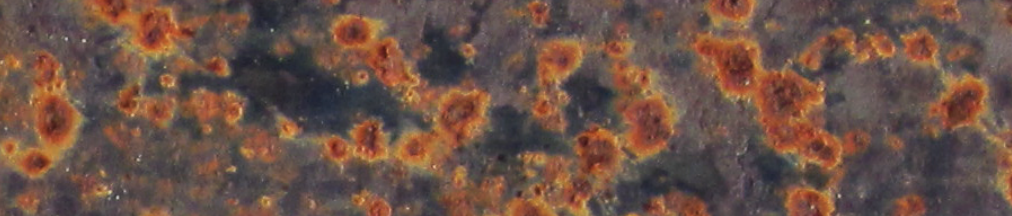

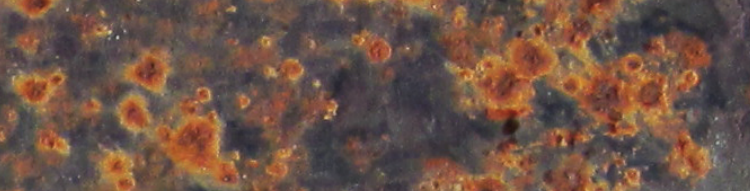

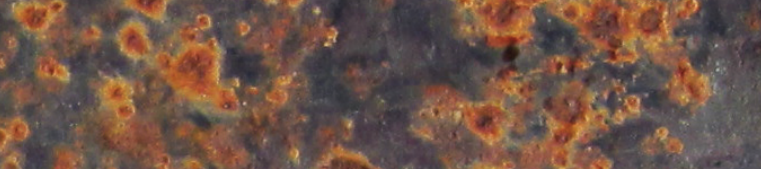

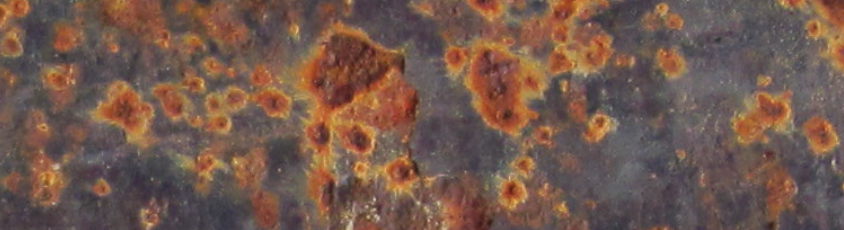

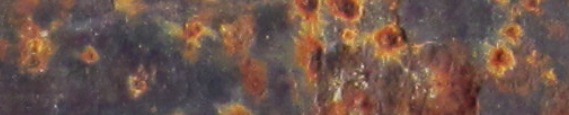

218

(1)

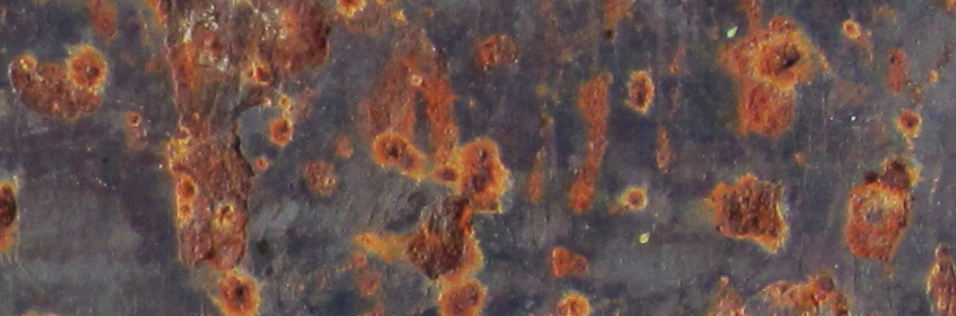

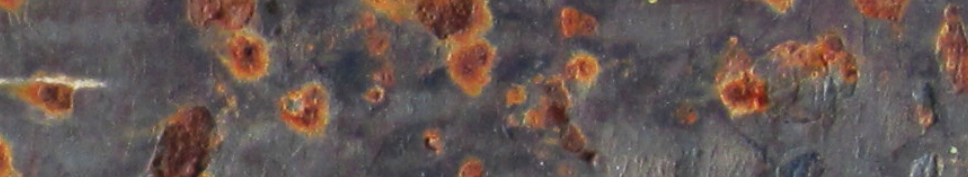

$x^{2}=2 \times 2$

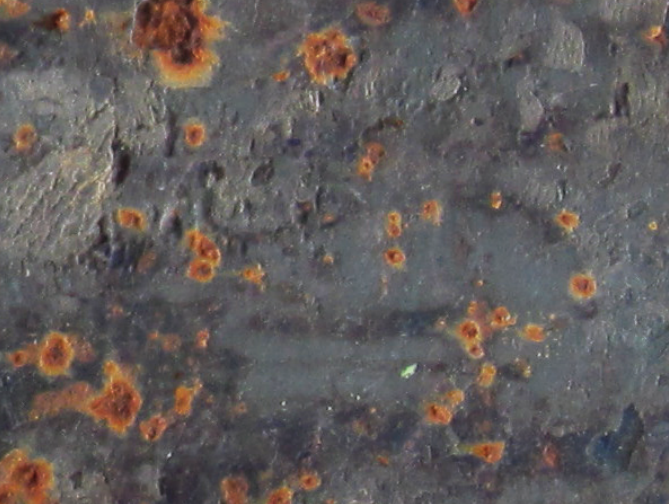

2.6.

2

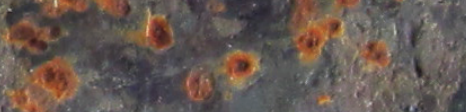

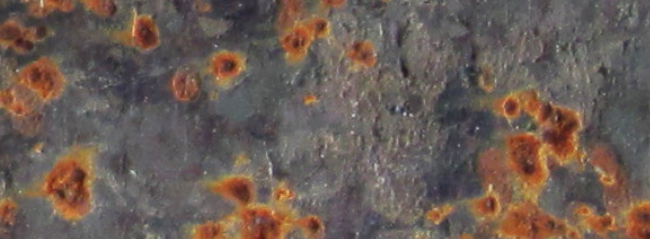

(4)

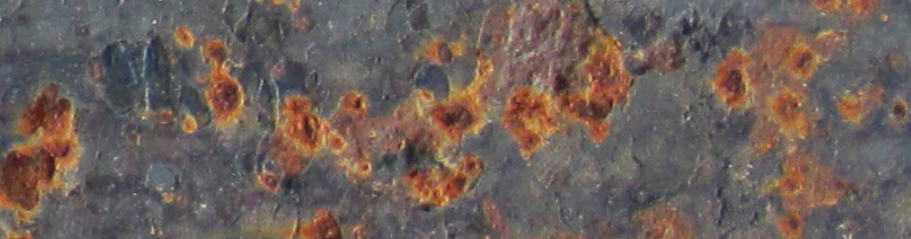

(4.) 20

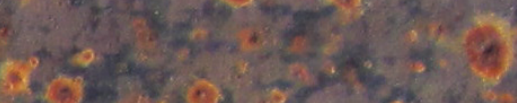

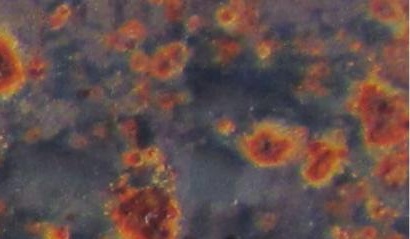
ond 20 : 

Z é o final do alfabeto, últimas palavras, é o zigue-zague, o zunido que ecoa dos outros vinte e dois verbetes. Agenciamentos entre arte, educação e filosofia da diferença. Buscou-se circunscrever o problema dessa pesquisa de um modo próximo ao método cartográfico, o que significou não desenhar um mapa como decalque, recortado e delimitado a seu espaço geográfico - o que, dentro da perspectiva que adotei, seria como encarcerar a aula de arte sem pensar nas multiplicidades que invadem o cotidiano dessa aula, sejam elas advindas do ambiente escolar, das referências que a reflexão e a pesquisa oferecem, além dos atravessamentos próprios do embate com o outro e com a vida.

Uma pesquisa que não sabe por onde irá passar, quais caminhos deverá tomar, enfim, não tem nada definido de antemão, assim como uma cartografia que se desenha em ato. É por isso, aliás, que a aula de arte como espaço problemático não poderia estar encerrada dentro de quatro paredes. Foi preciso lançar-se em disparos, com linhas de fuga em busca das mais diversas direções, e cuja intenção era compor um espaço para a prática artística dentro do ambiente escolar. Tratou-se de uma reinserção da arte na educação, não vista apenas como conteúdo, mas, fundamentalmente, como prática, como um saber, uma postura, e cujo foco está na proposição artística como o próprio do procedimento docente.

Para tanto, a necessidade de perpassar alguns dos principais problemas da aula de arte, entendendo que descortinar o que movimenta a cultura escolar da arte poderia abrir ou possibilitar aquilo que propõe Foucault quando fala sobre o papel de Nietzsche em seu trabalho: "precisamente utilizá-lo, deformá-lo, fazê-lo ranger, gritar... Que os comentadores digam se é o ou não fiel, isso não tem o menor interesse". ${ }^{1}$ Assim, apresentou-se diversas linhas que compõem a aula de arte, passando por seus territórios mais bem instituídos, questionando-os, propondo inflexões e, por vezes, subversões: do cânone da linguagem visual, da releitura e do desenho como forças-motrizes que operam no seio daquilo que se convenciona pensar sobre a aula de arte, passando pelo papel da constituição da disciplina "arte", suas condições de emergência, até à recepção e repetição de teorias da arte-educação e seus reflexos na cultura escolar em torno da arte - sempre a partir daquilo que vejo e ouço de meus alunos.

Por outro lado, isso não bastava, pois era preciso dar um outro contorno à pesquisa para que ela pudesse ser afirmativa e, sobretudo, viva e pulsante: daí o desejo de friccionar aquilo que me afetava ver e ler no universo das artes visuais com a sala de aula. Disso derivam as reflexões acerca do papel tanto da escola - do lugar e sentido da escola -, quanto do professor como artista, pesquisador, performer, crítico-etc. Mas, de que forma, na pesquisa, isso se deu? Por contágio, da reflexão-pesquisa em direção à aula, dos escritos dos artistas para a pesquisa e para a aula, em via de mão-dupla. 
A linha que percorre todas as letras - ou seja, que lhe dá sustentação teórica - é fornecida pelo pensamento da diferença, claramente influenciada pelo pensamento de Deleuze e Guattari, cujo projeto filosófico apresenta-se como uma afirmação da vida, da diferença, e, principalmente, da criação.

Neste sentido, do que antes era uma hipótese-intuição à intenção pode-se concluir que a verdadeira linha que percorre todas as vinte e três letras do alfabeto é a reivindicação da criação como modo de vida.

Nesse sentido, a filosofia deleuziana mostrou-se ser o intercessor necessário para desenvolver a hipótese-intuição de que esta pesquisa se propôs, na medida em que é notável que o projeto filosófico de Deleuze está totalmente voltado para o pensamento. Ou melhor, fica claro, no decorrer da obra do filósofo, seja a partir das teorias de outros filósofos, seja pela nãofilosofia, como escritos sobre literatura, artes visuais, cinema ou ciência, que seu interesse é o de tornar possível o pensamento.

Assim, a não-filosofia (representada pela arte e pela ciência) interessa à Deleuze, pois é vista como modo e expressão do pensamento, assim como opção para filósofos que buscam questionar a filosofia da representação, como Spinoza, Nietszche e Bergson.

O problema do pensamento é o que define a filosofia de Deleuze, sendo diferença, pois este filósofo critica as imagens do pensamento representacional como advindas da moral - pressuposição de que o pensamento é pré-filosófico e natural e ocorre sem qualquer esforço (cogito = Eu penso). Em contraposição a essa conjectura, o filósofo propõe um pensamento sem imagem - que seria, então, a própria diferença.

Daí derivam as tentativas de questionar o dogma da criatividade vista como criação, tão presente nos discursos da arte-educação e tão almejada pelos professores em seu ensino de arte ao longo desta pesquisa. Assim, em alguns verbetes, com alguma insistência, fala-se em criação como um acontecimento em oposição à noção de criatividade.

Trata-se, em última análise, de pensar a aprendizagem em arte a partir das suas diversas linhas, e, por isso, mais uma vez, a opção por não se restringir a um objeto, como de costume neste tipo de pesquisa inscrita na academia - ou seja, o objeto é a aula de arte como espaço de criação e aprendizagem e é essa característica que move todos os verbetes. Tomada como um problema, a noção de aprendizagem que circula nesta pesquisa se funde à noção de criação, pois, para Deleuze, a aprendizagem é algo da ordem do estranhamento e não da conjunção e da recognição. Segundo o filósofo, ela "não é entendida como passagem do não-saber ao saber, não fornece apenas as condições empíricas do saber, nem é uma transição ou uma preparação que desaparece com a solução ou resultado. A aprendizagem, é sobretudo, invenção de problemas, é experiência de problematização". ${ }^{2}$

Desta forma, em alguns verbetes, é possível perceber uma outra inclinação que perpassa a pesquisa, e que ultrapassa a aula de arte como principal objetivo, partindo-se, também, do

2 KASTRUP, Virgínia. "Aprendizagem, arte e invenção". Psicologia em Estudo, Maringá, v. 6, n. 1, jan/jun, 2001, p. 17-27, jan./jun. 2001. p. 17. Disponível em: http:/ $</ w w w . s c i e l o . b r / p d f / p e / v 6 n 1 / v 6 n 1 a 03$.pdf $\rightarrow$. Acesso em 04/07/2015. 
ponto de vista da criação - a ideia de "artistar" a educação presente no verbete "U", e direta e indiretamente nos verbetes sobre a escola e a educação.

O termo "artistar" é empregado pela pesquisadora Sandra Marra Corazza em vários de seus artigos e, especialmente, dá titulo a um de seus livros. Para ela, "artistagens" em educação são marcas que fazem o pensamento poder ser criado, marcas avessas à educação da imitação, das ideias prontas e dos livros didáticos. Artistar a educação é "educar como obra de arte, (...) como potência criadora (...) não importa de onde venha, se da filosofia, sociologia, antropologia", 3 o que importa é que ela não seja dogmática, não vire receita, não seja reprodução.

Certamente, a operação que se pretendeu com essa pesquisa propõe uma inflexão na ideia de arte que, ora se dobra ao seu próprio statement e, sobretudo, ao modo como a arte tem sido inscrita na educação, a partir de verbetes utilizados, tais como: "X da questão", "Quem tem medo da arte contemporânea", "Beabá da Arte", "Happening", "Interessante", "Parâmetros", etc. Este trabalho opera conforme a construção de dispositivos para penetrar na educação através de procedimentos artísticos - e disso decorre a noção de criação como cerne de alguns verbetes como: "Ecótono", "Flutuação", "Transcriação", "Uma estética da docência", etc.

A criação como procedimento, como já apresentado anteriormente, na filosofia da diferença, não é um privilégio da arte, pois a criação é condição do pensamento. No entanto, pelo menos no campo da educação, fica mais evidente o seu uso pela arte. Não obstante, a ideia levantada nos verbetes citados acima toma a arte como "um atrator caótico, um ponto que é tendencial, sem ser fixo e sem possibilitar falar em regimes estáveis ou em resultados previsíveis". ${ }^{4}$

Muito se fala em nome da criação, especialmente na educação. Para algumas perspectivas cognitivistas, a criação assume uma parcela de uma inteligência supostamente "diferente", um recurso que regula o excesso de racionalismo, ou, ainda, como mais valia no mercado, a criação é moeda de troca entre publicitários: brainstorming, soluções inusitadas, etc. Porém, "é preciso sair das dimensões cognitivistas, ontológicas e fenomenológicas dos estudos sobre criação, para pensar o que é o criar enquanto acontecimento produtor de diferença". ${ }^{5}$

Seguindo esse trilho, a criação é muito maior do que a criatividade e opera em qualquer tipo de disciplina, digo, no caso da educação, pois a criação é entendida como pensamento. Uma condição para pensar é criar.

A opção por trazer determinados artistas para os verbetes é tomada tendo como base o próprio procedimento proposto por Deleuze em sua filosofia - o uso da teoria como caixa de ferramentas. Ao se debruçar sobre um outro filósofo, Deleuze não o faz à maneira estática do comentarista, procedimento que é muito comum na história da filosofia. Ele argumenta: "Não há possibilidade de fazer filosofia, deleuzianamente falando, sem investir em um duplo campo: a constituição dos problemas e a criação dos conceitos". ${ }^{6}$

\footnotetext{
3 CORAZZA, Sandra. M. Artistagens: Filosofia da diferença e educação. Belo Horizonte: Autêntica, 2006,. p. 15-18. KASTRUP, Virgínia., op. cit., p. 19

ZORDAN, Paola. Criação na perspectiva da diferença. Disponível em: <http://cascavel.ufsm.br/revistas/ojs2.2.2/index.php/revislav/article/view/2135/1297 $\rightarrow$. Acesso em: 02/07/2015.

$6 \quad$ VASCONCELOS, Jorge. "A filosofia e seus intercessores: Deleuze e a não -filosofia". In; Revista: Educ. Soc.,
} 
Assim, os artistas (Cage, Tacita Dean, Allan Kaprow, Lygia Clark e tantos outros) tratados interessavam à pesquisa na medida em que seus escritos e obras operassem alguma inflexão ou estranhamento no senso comum em torno da arte; daí a preferência por artistas contemporâneos. Não importava a pesquisa, apenas o comentário do pensamento desse artistas; mas sim a partir deles, fazer a proposição de novos usos de seus procedimentos em educação. Dessa forma, foram apresentados problemas em cada um dos verbetes relacionados aos artistas selecionados. Junto ao pensamento desses artistas, foram propostas reflexões em forma ora de indício, ora de vestígio, com o cuidado de não configurar nenhum tipo de prescrição: as descrições são genéricas, não incluem a sequência didática precisa, tornam-se personagens de uma narrativa maior.

Tratou-se de privilegiar o pensamento e a criação em sala de aula em uma espécie de exercício do pensar, colocando movimento nos pressupostos e dados da arte na educação, fazendo-os ganhar outros tons, atualizando-os, questionando-os enquanto imagem dogmática do ensino da arte.

Os artistas, a filosofia da diferença, os embates do cotidiano em sala de aula e na educação funcionaram nesta pesquisa como meus intercessores, como o bando ou o deserto aos quais Deleuze sempre se refere ${ }^{7}$, algo da ordem do encontro. Sem eles, os intercessores, não há criação: "o essencial são os intercessores. A criação são os intercessores. Podem ser pessoas - para um filósofo, artistas ou cientistas; para um cientista, filósofos ou artistas -, mas também coisas, plantas, até animais, como em Castañeda. Fictícios ou reais, animados ou inanimados, é preciso fabricar seus próprios intercessores". ${ }^{8}$

No entanto, é importante fazer uma ressalva, considerando-se que a criação pode ser facilmente vista como a grande salvação da educação e que, ao operar a serviço desse discurso, também ela terá entrado para o reino dos clichês e do senso comum. Como abordado no verbete "Interessante", a opinião/clichê é "sempre recognição, um hábito, uma representação instituída, independente da sua incidência e de seu número de repetições". ${ }^{9}$ Ademais, avessa à conexão de senso comum que se costuma fazer entre criação e descoberta, organização, fluição, a noção de criação na filosofia da diferença, que toma com referência a filosofia de Bergson, baseia-se em dois aspectos: "em primeiro lugar, a invenção é sempre invenção de novidade, sendo, por definição, imprevisível. Em segundo lugar, para Bergson a invenção, em sentido forte, é sempre invenção de problemas e não apenas invenção de solução de problemas". ${ }^{10}$

É, portanto, com esse sentido da criação, que essa pesquisa se comprometeu, desde a

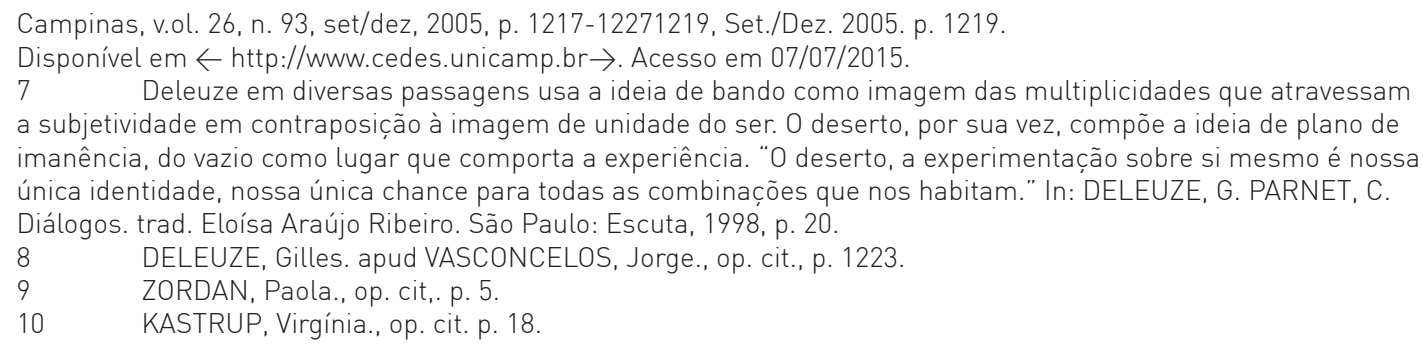


sua imprevisibilidade até a invenção de problemas, e o desejo de inundar a educação com essa potência, uma vez que não se trata de monopólio da arte e sim do pensamento, ela logo diz respeito à aprendizagem, diretamente.

Para Deleuze e Guattari, especificamente em O que é a filosofia?, é possível notar que todo o pensamento que se desenvolve ali gira em torno da criação, ao falar sobre o que caracteriza a filosofia, os autores falam em criação de conceitos, sobre as ciências e a arte, cada uma ocupada com a criação de funções, e afectos e perceptos, respectivamente. Para os pensadores, "a arte, a ciência e a filosofia, [são] como formas do pensamento ou da criação". ${ }^{11}$

A aprendizagem, por sua vez, não pode ser tomada como tarefa de recognição, fruto do encadeamentos de forças da inteligência de um sujeito, tendo em vista um objeto. Essa oposição sujeito/objeto, bem como todo tipo de formulação binária - as chamadas linhas duras, tendem a reduzir o campo de experimentação e de criação. A aprendizagem é pensada, com Deleuze e Guattari, como uma forma impessoal, ou seja, não ocorre no sujeito, mas naquilo que os autores chamam de "plano de composição" de subjetividade. Assim, o pensamento é uma força violenta que nos obriga a decifrar, pesquisar, questionar, interpretar.

Segundo Virgínia Kastrup, importante referência dos estudos em aprendizagem inventiva, a aprendizagem se dá no encontro entre o diferencial do sujeito e do objeto, que, por sua vez, são vistos também como produções, e não como dados fixos. Há contágio e contato com os signos presentes no mundo e são eles que no embate sujeito/objeto nos coagem, nos forçar a pensar e a aprender.

Deleuze, em Proust e os signos, faz uma importante reflexão sobre o que é um signo, para além do proposto na linguística de Saussure, que aborda o significado e significante. Para Deleuze, os signos não são restritos à linguagem - toda matéria apresenta um tipo de signo. "O signo é objeto de um encontro; mas é precisamente a contingência do encontro que garante a necessidade daquilo que ele faz pensar. $\mathrm{O}$ ato de pensar não decorre de uma simples possibilidade natural; ele é, ao contrário, a única criação verdadeira. A criação é a gênese do ato de pensar no próprio pensamento". ${ }^{12}$

Seguindo esse trilho, Kastrup afirma que apenas "quando somos tocados pelo signo, pela diferença, temos uma experiência de problematização, de invenção do problema. Só a partir daí ocorre a busca de solução e de sentido". ${ }^{13}$

Dessa maneira, pode-se dizer que a aprendizagem ocorre quando somos forçados a pensar, por exemplo, em uma viagem, em todos os mais simples gestos habituais, pois eles são desafiados o tempo todo dado o estranhamento que um outro espaço nos evoca. Coisas simples, como ícones de trânsito, mapas, torneiras, produzem situações que nos forçam a aprender, criando soluções que nos são forçadas, estremecendo padrões e ideias pré-concebidas ou tidas como naturalizadas em nosso ambiente original. Inclusive, quando regressamos, o fruto dessa

DELEUZE, G. GUATTARI, F. 0 que é a filosofia?. São Paulo: Editora 34, 2010, p. 267.

DELEUZE, Gilles. Proust e os signos. Trad. Antônio Carlos Piquet e Roberto Machado. Rio de Janeiro: Forense Universitária, 2003,. p. 92.

13 KASTRUP. Virgínia., op. cit., p. 20 
aprendizagem aparece sob a forma de uma percepção mais acurada do espaço, e prestamos mais atenção em elementos que, no cotidiano, eram considerados frívolos, como a faixa de pedestre, o canteiro central com árvores, etc.

Assim, seguindo na esteira deleuziana, pode-se dizer que tivemos uma aprendizagem, pois pensar/criar sempre condiz com a ordem do estranhamento e não da conjunção, de forma que, apesar da memória do espaço original, o viajante, ao retornar com uma nova sensibilidade aprendida em outro espaço, problematiza e estranha o que vê.

Pensar/criar/aprender não é tarefa simples, mas sempre uma violência e uma necessidade, um processo de extração e esforço. Davi não saiu em seus mais de dois metros de altura sem que Michelangelo tenha tido grandes embates com a matéria-mármore. Aliás, em uma de suas célebres frases, Michelangelo conta que via em cada bloco de mármore uma escultura que bastava ser retirada dali, excelente exemplo da criação.

Ainda para Kastrup, a arte pode e deve ser tomada como uma perspectiva ou ponto de vista retroagindo sobre os outros signos e sobre a educação. E, nesse sentido, foram pensados verbetes como "Beabá da arte", "Já acabei", como desejo de ampliar o senso comum de uma recognição através do conteúdos artísticos, pois tal empreitada vai na contramão da proposição desta pesquisa, que defende que a aula de arte seja um espaço de criação!

Mas, afinal, qual seria o problema de se encarar a arte como (re)cognição? De uma perspectiva deleuziana, a cognição se apresenta como uma imagem do pensamento, um senso comum de que é possível compartilhar de um ponto de vista interior um mesmo sentido do "eu", capaz de observar o mundo de uma mesma forma.

Em uma análise cuidadosa da imagem do pensamento na obra deleuziana, especificamente em Diferença e repetição, Jorge Vasconcelos descreve os quatro postulados fundamentais nos quais o pensamento como imagem dogmática se inscreve, um deles se relaciona com a ideia de recognição. Segundo o autor, na obra de Deleuze, o modelo da recognição "se define pelo exercício concordante de todas as faculdades sobre um objeto suposto como sendo o mesmo: é o mesmo objeto que pode ser visto, tocado, lembrado, imaginado, concebido (...)". ${ }^{14}$ Ou seja, Deleuze desnuda a falsa ideia de que haja um modelo de funcionamento do pensamento comum a todos, identitário e a partir do qual tudo pode ser examinado da mesma forma. A esse respeito, a própria arte não cessa de apresentar inúmeras leituras e interpretações, considerando-se apenas o ponto de vista do espectador, sem levar em consideração as diferentes sensibilidades em torno da mesma matéria, por parte dos artistas (por exemplo, o bronze de Rodin se difere em absoluto do bronze de Giacometti).

Nesta pesquisa, o problema da criação implica um desejo, ou melhor, um agenciamento, já que desejo é sempre um agenciamento de coisas. Neste caso, agencia-se a vontade de fazer diferença, no sentido deleuziano, e, por isso, vale salientar que não se trata de querer buscar com esse abecedário a reivindicação de algo "original", como transcendência, ideia comum provavelmente vinculada ao axioma de Lavoisier "nada se cria, tudo se transforma", a partir do 
qual a ideia de criação é extramundana, originária de tudo o que está no mundo. "Seguindo a lógica daquilo que já existe, já é dado, atual, real, palpável, pode se dizer que tudo o que se conhece é criação. Daí, apesar do inevitável embate com a mutabilidade das coisas, é muito fácil confundir o que se conhece e já foi criado com o que se toma por "verdade". Como expressão do conhecimento e da verdade, a criação se torna uma instância transcendente, de modo que tudo o que resta ao homem é "criatividade" para transformar o que já foi feito.". ${ }^{15}$ Disso deriva a insistência pela qual a ideia de criatividade é problematizada em alguns verbetes como "O que vocês estão vendo?" e "Livre expressão".

A criação, da perspectiva de Deleuze e Guattari, não é, portanto, fazer o original, visto que não é transcendental nem constituída de verdades essenciais - e, talvez, seja justamente sua imprevisibilidade que a faça ser banida da escola. Nesse sentido, "quando escrevem que 'criar é resistir', pensam em devires e acontecimentos, potências virtuais não necessariamente atualizadas ou em processos de atualização. A estratégia é resistir ao atual, seguir sensações e devires, experimentar os territórios virtuais do plano de imanência". ${ }^{16}$

Ainda no agenciamento de desejos que movem essa pesquisa encontra-se a ideia de criação como resistência, da função da arte na educação como um espaço de militância, aquele lugar onde se opera na solidão, na esperança de um povo que não existe, pois, para Deleuze, a arte é um ato de resistência, é o que fica depois da morte, pois "não existe obra de arte que não faça apelo a um povo que ainda não existe". ${ }^{17}$

Ao final, no eco que zune e ressoa dessa pesquisa, está uma busca pelo afeto, na tentativa de reconectá-lo ao lugar da aprendizagem pela via da criação. Nesse sentido, dois intercessores pouco tratados nesta pesquisa apresentam-se como um importante pano de fundo tanto para a criação de conceitos na filosofia deleuziana quanto para o que se almeja com esse abecedário.

Trata-se de Spinoza e Nietzsche, pois ambos trazem em suas filosofias algo que Nietzsche chamou de uma "tendência geral" comum, a partir da qual os filósofos entendem a produção de conhecimento (pensamento) não como uma atividade neutra, desinteressada e muito menos objetiva, mas sim como uma atitude intimamente conectada aos impulsos humanos, caracterizada pelos dois como "o mais potente dos afetos". ${ }^{18}$

Apesar de seguirem caminhos distintos, o próprio Nietzsche, alguns anos depois, escreve ataques a Spinoza, porém, independentemente das diferenças, é possível perceber a vizinhança no projeto filosófico de cada um dos autores.

Spinoza pensa que, através de uma ética do conhecimento, que faz a crítica a uma moral da obediência, é que se poderia aceder ao conhecimento, pois nunca se conhece por conhecer: o conhecimento ocorre por e para o afeto, para então sermos afetados por ele. Mais ou menos

\footnotetext{
15 ZORDAN, Paola., op. cit., p. 3.

16 Idem, ibidem.

17 DELEUZE, Gilles. “O ato de criação.” tradução de José Marcos Macedo, publicado na Folha de S. Paulo de 27/06/1999. p. 5. Disponível em: http://escolanomade.org/images/stories/biblioteca/downloads/deleuze_ato_de_criacao. pdf. Acesso em 20/08/2015.

$18 \quad$ Carta de Nietzsche ao amigo Franz Overbeck de 30 de julho de 1881. InN: MARTINS, A. (org.) 0 mais potente dos afetos: Spinoza \& Netzsche. São Paulo: Ed. WMF Martins Fontes, 2009,. p. XVII.
} 
como diz Kafka em uma carta que escreve a Oscar Pollak, em 1904: "Acho que só devemos ler a espécie de livros que nos ferem e trespassam. Se o livro que estamos lendo não nos acorda com uma pancada na cabeça, por que o estamos lendo? (...) Mas nós precisamos de livros que nos afetam como um desastre, que nos magoam profundamente, como a morte de alguém a quem amávamos mais do que a nós mesmos, como ser banido para uma floresta longe de todos. Um livro tem que ser como um machado para quebrar o mar de gelo que há dentro de nós. É nisso que eu creio."19

Junto a Spinoza, encontra-se uma aprendizagem para a criação, que ocorre fundamentalmente no corpo, pois criar é uma experiência afetiva que acomete o corpo, que o faz diferente, estranho, outro. Para o filósofo holandês "o itinerário ético é então um percurso do conhecimento, que, simultaneamente, toma por objeto a afetividade humana e pretende transformá-la, ou ao menos vivê-la de outra maneira(...)".20

Dessa forma, este abecedário, longe de qualquer totalização, baseia-se em uma construção afetiva, e parte disso sua intenção de não ser nada além de um agenciamento e um convite à experimentação na vida (docente), na escola, com o outro alunos, nem ter contudo a necessidade de se afirmar nenhuma virtude ou verdade.

Trata-se, sobretudo, de agir ali onde há possibilidade de apequenar e embrutecer a experiência, já que, com Spinoza,

o corpo humano pode ser afetado de muitas maneiras, pelas quais sua potência de agir é aumentada ou diminuída, enquanto tantas outras não tornam sua potência de agir nem maior nem menor. ${ }^{21}$

O que vemos, muitas vezes, na escola, é a existência de poucos afetos: o que se faz por ali não aumenta nem diminui as potências do corpo. Não parece se passar pelo corpo.

Nesse sentido, inúmeras das experimentações de sala de aula descritas e propostas dependem fundamentalmente do corpo, na busca desse afetos, desse contato, ainda que eles paralisem e dificulte, a passagens desses afetos - já que pouco espaço existe para isso no ambiente escolar.

Em Spinoza, o corpo é definido pela capacidade de afetar e de ser afetado. Por afeto, entende-se não apenas sensações, mas, como definiria o filósofo, trata-se de um tipo de ideia: "uma ideia confusa, pela qual a mente afirma uma força de existir, maior ou menor do que antes, de seu corpo ou de uma parte dele (...)".22 Portanto, toda aquele discurso sobre os conteúdos e a sensação que percebo em meus alunos não

19 KAFKA, Franz. Carta a Oscar Pollak, 1904. In: PELBART, Peter Pál. Revista Trópico. Diponível em http://www. revistatropico.com.br/tropico/html/textos/2409,1.shl, Acesso em: 20/08/2015

20 IN: MARTINS, A. lorg.) 0 mais potente dos afetos: Spinoza \& Netzsche. São Paulo: Ed. WMF Martins Fontes,

2009, p. XVIII.op. cit. p.18

21 SPINOZA, Benedictus. Ética/Spinoza. Belo Horizonte: Autêntica Editora, 2007. Postulado 1. $3 a$ parte, p. 99

$22 \quad$ Idem, p. 152 
entenderem o motivo de estudarem determinado assunto ressoa em um tipo de afeto triste, na despontecialização do que pode um corpo, do que pode florescer do encontro com aquilo que é novo e impensado.

Em um caminho parecido opera Nietzsche, que, ao invés de propor o conhecimento por meio dos afetos, como faz Spinoza, apresenta o conhecimento como uma paixão, em uma busca de criar condições que pudessem reunificar o intelecto e a vontade, o conhecimento e as paixões.

Ainda que pareça um paradoxo, Nietzsche propõe uma desrazão da paixão do conhecimento, ou seja, ele defende que a paixão do conhecimento é um tipo de abertura ao mundo e às coisas que estão fora de mim e a mim são desconhecidas; é paixão no sentido que nos faz sair de nós mesmos, abandonando perspectivas conhecidas, traçando novos percursos, reinventando-se. "O conhecimento transformou-se, em nós, em paixão", 23 e se isso ocorre em Nietzsche é porque "o nosso impulso ao conhecimento é demasiado forte". ${ }^{24}$

Portanto, seria ainda nessa chave do afeto e da paixão pelo conhecimento que a aula de arte, e toda a educação, poderiam operar, a fim de que a potência de vir a ser quem se é, no sentido foucaultiano da experiência, poderia ser levado a cabo. Para que conhecer ou experimentar o saber em qualquer que seja o seu viés seja um ato consentido que se vive no presente, que nos possibilita uma transfromação.

Finalmente, o que se pretendeu nesses agenciamentos todos, com Lygia, Kaprow, Duchamp, crianças da Escola de Aplicação, Nietzsche, Deleuze, John Cage, Donald Judd, Marina Abramovic, Benjamin, adolescentes da Escola de Aplicação, Guattari, Ricardo Basbaum, Tácita Dean, Spinoza, Sandra Mara, e toda a escritura deste abecedário, foi afirmar que não só "as palavras têm sabor (saber e sabor tem a mesma etimologia)",25 como dizia Barthes, mas que devemos perseguir em uma ação contínua de resistência na criação de um projeto ético-estético-político na educação. A partir desse projeto, a arte, a criação, o saber e o sabor devem nos reconectar com nossas paixões pelo conhecimento, pois, quem decide trabalhar na educação deve ter atendido um chamado - um momento, uma pequena epifania, na qual o conhecimento nos invadiu com tamanha paixão e afetação que tornou-se tão saboroso, ao ponto de querermos compartilhá-lo com o outro. É isso que nos mantém resistindo na educação e é isso que faz com que não deixemos nos esmorecer em terras que não podemos permitir que sejam abandonadas.

\footnotetext{
23 NIETZSCHE, Friedrich WilhelmW; DE SOUZA, Paulo César. Aurora: reflexões sobre os preconceitos morais Editora São Paulo: Companhia das Letras, 2004,. p. 278.

24 PONTON, Olivier. "Fazer do conhecimento o mais potente dos afetos". IN:In: MARTINS, A. (org.), op. cit.0 mais potente dos afetos: Spinoza \& Netzsche. São Paulo: Ed. WMF Martins Fontes, 2009,. p. 43.

25 BARTHES, Roland. Aula inaugural da Cadeira de Semiologia Literária do Colégio da França pronunciada dia 7 de janeiro de 1977. São Paulo: Cultrix, 1988. p. 21.
} 



\section{Bibliograflia}



AGAMBEN, Giorgio. O que é o contemporâneo? e outros ensaios. Trad. Vinicius Nicastro Honesko. Chapecó: Argos, 2009.

ALBERS, Joseph. In: Goldberg, Roselee. A Arte da Performance - Do Futurismo ao Presente. São Paulo: Martins Fontes, 2006.

ALBERS, J. A interação da cor. São Paulo: WMF Martins Fontes, 2009.

ALLIEZ, Eric. Gilles Deleuze: uma vida filosófica. São Paulo: Ed. 34, 2007.

AQUINO, Julio Groppa. Instantâneos da escola contemporânea. São Paulo: Papirus, 2007. . Fragmentos de um discurso sobre a infância. Childhood \& philosophy. Rio de Janeiro, v.8, n.15, jan./jun. 2012, pp. 33-66.

. A escrita como modo de vida: conexões e desdobramentos educacionais. Revista:

Educação e Pesquisa, v. 37, n. 3, p. 641-656, 2011.

ANDRADE, C.D de. A Flor e a Náusea. In: Poesia completa. Rio de Janeiro: Nova Aguilar, 2002.

AQUINO, Julio Groppa e CORAZZA, Sandra Mara. (orgs.). Abecedário: Educação da Diferença. Campinas: SP: Papirus, 2009.

BARBOSA, Ana Mae. A imagem no ensino da arte. Anos oitenta e novos tempos. São Paulo: Perspectiva, 2009.

. Arte-educação: Conflitos e Acertos. São Paulo: Max Limonad, 1984.

Arte-educação no Brasil. São Paulo: Perspectiva, 2002.

. Tópicos utópicos. Belo Horizonte: C/Arte, 1998.

.(org.) Inquietações e mudanças no ensino da arte. São Paulo: Cortez, 2002.

John Dewey e o ensino da arte no Brasil. São Paulo: Cortez, 2002.

Arte-Educação no Brasil: realidade hoje e expectativas futuras. Estud. av. [online].

1989, vol.3, n.7. pp. 170-182. Disponível em: <http://www.scielo.br/scielo.php?script=sci_ arttext\&pid=S0103-40141989000300010\&lng=en\&nrm=iso>. Acesso em 29/06/2014.

BARBOSA, Ana Mae; Sales, Heloisa Margarido. O ensino da arte e sua história. São Paulo: MAC/ USP,1990.

BARTHES, Roland. Escritores, Intelectuais, Professores e outros ensaios. Lisboa: Presença, 1975. . Aula inaugural da Cadeira de Semiologia Literária do Colégio da França pronunciada dia 7 de janeiro de 1977. São Paulo: Cultrix, 1988. p. 21.

. O prazer do texto. São Paulo: Perspectiva, 2008.

. Inéditos, vol. 1 - teoria. S. Paulo: Martins Fontes, 2004.

. Fragmentos de um discurso amoroso. Rio de Janeiro: Ed. Alves, 1981.

BASBAUM, Ricardo. Além da Pureza Visual. Porto Alegre: Zouk. 2007.

. Eu amo artistas-etc. In: Políticas Institucionais, Práticas Curatoriais,

Rodrigo Moura (Org.), Belo Horizonte, Museu de Arte da Pampulha, 2005. Disponível em: https:// rbtxt.files.wordpress.com/2009/09/artista_etc.pdf. Acesso em 20/12/2015.

BENJAMIN, W. Magia e técnica, arte e política: Ensaios sobre literatura e história da cultura. Obras Escolhidas. trad. Sérgio Paulo Rouanet. São Paulo: Brasiliense, 1994.

BIASOLI, Carmen Lúcia Abadie. A formação do professor de arte: Do ensaio...à encenação. Campinas: SP. Papirus, 1999

BLANCHOT, Maurice. A conversa infinita: a experiência limite. trad. João Moura Jr. São Paulo: Escuta, 2007. O livro por vir. São Paulo: MFW Martins Fontes, 2005. 
BRASIL. Secretaria de Educação Fundamental. Parâmetros curriculares nacionais : arte / Secretaria de Educação Fundamental. - Brasília : MEC/SEF, 1997.

BRASIL. Secretaria de Educação Fundamental. Parâmetros curriculares nacionais 2. Arte : Ensino de quinta a oitava séries. Secretaria de Educação Fundamental. - Brasília : MEC / SEF, 1998.

BOURRIAUD, Nicolas. Esthétique relationelle. Paris: les presses du réel, 2001.

BRITO, Ronaldo; DE LIMA, Sueli. Experiência crítica. São Paulo: Ed. Cosac Naify, 2005. O moderno e o contemporâneo (O novo e o outro novo). In: BASBAUM, R. (org.)

Arte contemporânea brasileira: texturas, dicções, ficções, estratégias. Rio de Janeiro: Rios Ambiciosos, 2001. p. 204.

CAMPOS, Haroldo. Transcriação. TAPIA, M. NÓBREGA, T. M. (orgs.) São Paulo: Perspectiva, 2013. CAUOUELIN, Anne. Arte Contemporânea: uma introdução. trad. Rejane Janowitzer. São Paulo: Martins Fontes, 2005. São Paulo: Martins, 2009.

COCCHIARALE, Fernando. Quem tem medo da arte contemporânea? Recife: Fundação Joaquim Nabuco, 2007. CORAZZA, Sandra Mara. Artistagens: Filosofia da Diferença e Educação. Belo Horizonte: Autêntica, 2006. . O que se transcria em educação? Porto Alegre: UFRGS, 2013. Contribuições de Deleuze e Guattari para as pesquisas em educação.Revista Digital do LAV, n. 8, p. 125-144, 2012. Disponivel em: http://cascavel.cpd.ufsm.br/revistas/ojs-2.2.2/index.php/revislav/article/view/5298/3225. Acesso em 10/07/2015. . Os cantos de fouror: Escrileitura em Filosofia-Educação. Rio Grande do Sul: ed. Sulina, 2008.

Pesquisar o currículo como acontecimento: em V exemplos. Artigo UFRGS. Disponível em: www.anped.org.br/reunioes/27/gt12/t1211.pdf. Acesso em 13/07/2014. . A formação do professor-pesquisador e a criação pedagógica. In: Revista da FUNDARTE. - ano.1, v. 1, n.1 (jan.-jun. 2001) - Montenegro : Fundação Municipal de Artes de Montenegro, 2001-. p. 14.

DEBORD, Guy. Teoria da deriva. Texto publicado no $n^{\circ} .2$ da revista Internacional Situacionista em dezembro de 1958. Segunda tradução (espanhol - português) por membros do Gunh Anopetil em 19 de março de 2006. Disponível em: https://teoriadoespacourbano.files.wordpress. com/2013/03/guy-debord-teoria-da-deriva.pdf. Acesso em 20/07/2015.

DELEUZE, Gilles. Conversações: 1972-1990. trad. Peter Pál Pelbart. São Paulo: Editora 34, 1992. Foucault. trad. Claudia Sant'Anna Martins. São Paulo: Brasiliense, 2005.

. "O ato de criação". Trad. José Marcos Macedo. Em: Folha de São Paulo, Caderno Mais!,

27 de junho de 1999. Lógica do sentido. São Paulo: Perspectiva, Edusp, 1974.

Pensamento nômade. In: MARTON, S. (org.). Nietzsche hoje? São Paulo: Brasiliense, 1985. p.56-76.

. Proust e os signos. Trad. Antônio Carlos Piquet e Roberto Machado. Rio de Janeiro: Forense Universitária, 2003.

O que é um dispositivo. In: O mistério de Ariana. Ed. Vegas -Passagens: Lisboa, 1996.

Disponível em: http://pt.scribd.com/doc/48275693/O-que-e-um-dispositivo-Gilles-Deleuze. Acesso em 16/07/2014.

DELEUZE, Gilles, GUATTARI, Félix. O que é a filosofia? trad. Bento Prado Jr. e Alberto Alonso Muñoz. São Paulo: Editora 34, 1992.

Mil Platôs. Capitalismo e Esquizofrenia. Vol. 1. Trad. Aurélio Guerra Neto e Celia Pinto 
Costa. São Paulo: Editora 34, 1995.

Mil Platôs. Capitalismo e Esquizofrenia. Vol. 2. Trad. Ana Lúcia de Oliveira e Lúcia Cláudia Leão. São Paulo: Editora 34, 1995.

. Mil Platôs. Capitalismo e Esquizofrenia. Vol. 3. Trad. Aurélio Guerra Neto, Ana Lúcia

de Oliveira, Lúcia Cláudia Leão e Suely Rolnik. São Paulo: Editora 34, 1996.

. Mil Platôs. Capitalismo e Esquizofrenia. Vol. 4. Trad. Suely Rolnik. São Paulo: Ed. 34,

$1^{\text {a }}$ reimpressão -2002.

DELEUZE, G. PARNET, C. Diálogos. trad. Eloísa Araújo Ribeiro. São Paulo: Escuta. 1998.

DERDYK, E. Disegno.Desenho.Desígnio. São Paulo: Ed. Senac, 2007.

DE SOUZA, Paulo César.Aurora: reflexões sobre os preconceitos morais. Editora Companhia das Letras, 2004.

DEWEY, John. Arte como experiência. São Paulo: Martins, 2010.

DUCHAMP, Marcel. O Ato Criador. In: BATTCOCK, Gregory. A nova Arte. São Paulo. Perspectiva: 2004.

DUTRA, Analice P. A educação do olhar no ensino das artes. Porto Alegre: Mediação, 2009.

DUVE, Thierry de. Fazendo escola (ou refazendo-a?). Chapecó: Argos, 2012.

. Sintoma e intuição. IN: Revista Novos Estudos-CEBRAP 79 (2007): 211-226. Dis-

ponível em: http://www.scielo.br/scielo.php?pid=S0101-33002007000300011\&script=sci_arttext. Aceso em 01/08/2014.

FABRINNI, Ricardo. Fim das vanguardas. Poliética. São Paulo, v. 1, n. 1, pp. 167-183, 2013.

FAVARETTO, Celso. Arte Contemporânea e Educação. In: Revista Iberoamericana de Educación. N.o 53 (2010). Disponível em: www.rieoei.org/rie53a10.pdf. Acesso em 29/06/2014. . Deslocamentos: entre a arte e a vida.In: Revista ARS, São Paulo, v. 9, n. 18, p. 94-109,

2011.

Experiência estética, instituições e educação. Revista Marcelina, ano 3, n. 4, São

Paulo: FASM, 2010.

Pós-moderno na educação. Rev. Fac. Educação. v.17. ns. 1/2. p. 121 - 127, jan./dez. 1991.

. A cena contemporânea, criação e resistência. In: FONSECA, Tânia Galli. PELBART, P. E

ENGELMAN, S. (orgs.) A vida em cena. Rio Grande do Sul: Editora da UFRGS, 2008.

. Fronteiras da arte e da vida. Texto apresentado no Simpósio "Deslocamentos e (des)

territórios: fronteiras da arte e da vida". $21^{\circ}$. Encontro Nacional da ANPAP, "Vida e Ficção/ Arte e Fricção", 24-29/09/2012. Publicado em:

GERALDO, Sheila Cabo (org.). Fronteiras: arte, imagem, história. Rio de Janeiro: Beco do Azougue/ Faperj, 2014, p. 17-30.

FERRAZ, Maria Heloisa C. de T.; FUSARI, Maria Felisminda de R. e. Arte na Educação Escolar. São Paulo: Cortez, 1992.

FERREIRA, G. e COTRIM, C. Escritos de artistas 60/70. Rio de Janeiro: Jorge Zahar Ed., 2009.

FLAUBERT, Gustave. Dicionário das ideias feitas. trad. Cristina Murachco. São Paulo: Nova Alexandria(1995).

Bouvard e Pécuchet. trad."Mariana Appenzeller. São Paulo: Estação Liberdade(2007).

FOUCAULT, Michel. História da sexualidade II: o uso dos prazeres. 8. ed. Rio de Janeiro: Graal, 1998.

. As palavras e as coisas: uma arquelogia das ciências humanas. trad. Salma Tannus

Muchail. São Paulo: Martins Fontes, 2007.

. Ditos e escritos. Arqueologia das ciências e história dos sistemas de pensamento. 
MOTTA, Manoel Barros da (Org.). Trad. de Elisa Monteiro. Rio de Janeiro: Forense Universitária, 2000. v. 2.

Ditos e escritos. Estética: literatura e pintura, cinema e música. trad. Inês Autran Dourado Barbosa. Rio de Janeiro: Forense Universitária(2009). v.3.

Ditos e escritos. Ética, estratégia, poder-saber. Rio de Janeiro: Forense Universitária,

2003. v. 4.

Ditos \& Escritos V - Ética, Sexualidade, Política. Rio de Janeiro: Forense Universitária,

2004

A ordem do discurso. São Paulo: Edições Loyola, 2004.

. Em defesa da sociedade. São Paulo: Martins Fontes, 2003.

Microfísica do Poder. org., intr., revisão técnica de Roberto Machado, Rio de Janeiro:

Graal, 1993. Rio de Janeiro: Graal: 1993.

Est-il donc importante de penser? Entrevista com Didier Eribon. Libération, $n^{0} 15$,

30-31 maio de 1981, p. 21. Traduzido a partir de FOUCAULT, Michel. Dits et Écrits. Paris: Gallimard, 1994, vol. iV, pp. 178-182, por Wanderson Flor do Nascimento. Disponível em: www.unb. br. Acesso em 13/10/2009.

Estética da existência. Disponível em: www.filoesco.unb.br/foucault. Acesso em 13/06/2014 às 22 hoo.

GALARD, Jean. Estética e política: mal-estar na imagem. O trivial e sua representação. trad. Cristina Prado. Revista Discurso, v. 41, n. 41, p. 29-46, 2011. p. 40 Disponível em: http://www.revistas. usp.br/discurso/article/viewFile/68364/pdf_59. Acesso em 01/08/2015.

GALLO, Silvio. Deleuze e a Educação. Belo Horizonte: Autêntica, 2008.

GROYS, Boris. A solidão do projeto. tradução Roberto Winter. Disponível em: http://projetosnatemporada.org/eventos/arte-projeto/groys/solidao-do-projeto/ Acesso em 07/03/2014. Art Power. Cambridge: MIT Press, 2008.

GUATTARI, Félix. As Três Ecologias. Trad. Maria Cristina F. Bittencourt. Campinas: Papirus, 1992.

HONORATO, Cayo. Arte como Atitude: Entrevista com Luis Camnitzer. Disponível em: http://wwwconcinnitas.uerj.br/resumos12/honorato.pdf. Acesso em 17/10/09.

. Expondo a mediação educacional: questões sobre educação, arte contemporânea e política. Disponível em: www.cap.eca.usp.br/ars9/cayo_honorato.pdf. Acesso em 09/06/2014. HOROWITZ, F. DANILOWITZ, B. Josef Albers: to open eyes: The Bauhaus, Black Mountain College and Yale. Nova lorque: Phaidon, 2006

KAFKA, Franz. Um relatório para a academia. Disponível em: http://escapismo.tumblr.com/ post/23759608241/um-relatorio-para-a-academia-franz-kafka-1917. Acesso em 29/06/2014.

KAPROW, Allan. Essays on the Blurring of Art and Life. Berkeley, CA: University of California Press, 1993. Performing Life. Revista ARS vol.8no.15São Paulo 2010.

. A educação do Un-artista. Revisão técnica Ricardo Basbaum. Revista Concinnitas, ano 5. número 6, julho de 2014. Disponível em: http://issuu.com/websicons4u/docs/revista6/169. Acesso em 03/05/2015.

Sucessos e fracassos quando a arte muda. Arte \& Ensaios, Rio de Janeiro, v. 18, julho de 2009. Disponível em: http://www.ppgav.eba.ufrj.br/wp-content/uploads/2012/01/ae18_allan_kaprow.pdf. Acesso em 02/05/2015.

KASTRUP, Virgínia. Aprendizagem, arte e invenção. Psicologia em Estudo, Maringá, v. 6, n. 1, p. 1727, jan./jun. 2001. p. 17. Disponível em: http://www.scielo.br/pdf/pe/v6n1/v6n1a03.pdf. Acesso 
em 04/07/2015.

KOHAN, Walter Omar, TADEU, Tomaz. Dossiê: entre Deleuze e a educação. Educação \& Sociedade. Campinas: Cedes. Set/dezzo05.

LAROSSA, Jorge. Pedagogia Profana. Danças, piruetas e mascaradas. Belo Horizonte: Autêntica, 2010.

Nietzsche e a Educação. Belo Horizonte: Autêntica, 2009.

LIMA, Alceu Amoroso. Estudos literários. v. 1. Rio de Janeiro: Companhia Aguilar Editora, 1966.

LYOTARD, J-F. Moralidades pósmodernas. Trad. bras., Campinas: Papirus, 1996.

. O pós-moderno explicado às crianças. Lisboa: Dom Quixote, 1987. p.26.

MARTINS, A. (org.) O mais potente dos afetos: Spinoza \& Netzsche. São Paulo: Ed. WMF Martins Fontes, 2009.

MATESCO, Viviane. Corpo, imagem e representação. Rio de Janeiro: Jorge Zahar Ed., 2009.

NIETZSCHE, Friedrich. Além do Bem e do Mal. Prelúdio para uma filosofia do futuro. São Paulo: Cia. Das Letras, 1992.

NIETZSCHE, F. A arte em "O nascimento da Tragédia". In: Nietzsche - Vida e Obra. São Paulo: Nova Cultural, 1999.

A gaia ciência. Trad. Paulo César de Souza. São Paulo: Companhia das Letras, 2011,

p. 202.

OBRIST, Hans Ulrich. Arte Agora! Em cinco entrevistas. São Paulo: Alameda, 2006.

Entrevistas. vol. 1. Rio de Janeiro: Cobogó; Belo Horizonte: Instituto Cultural Inhotim, 2009.

Entrevistas. vol. 5. Rio de Janeiro: Cobogó; Belo Horizonte: Instituto Cultural Inhotim, 2011. Hans Ulrich Obrist interviews. 1. Ed. Thomas Boutoux. Ed. Charta, 2003.

O'HARA, Frank. Jackson Pollock. Belo Horizonte:Itatiaia,1960.

OITICICA, Hélio et al.Aspiro ao grande labirinto. São Paulo: Rocco, 1986.

PASSOS, E. KASTRUP, V. ESCOSSIA, L (orgs.). Pistas sobre o método cartográfico: pesquisa-intervenção e produção de subjetividade.Porto Alegre: Sulina, 2009.

PELBART, Peter Pál. Solidão, fascismo e literalidade. In: DOSSIÊ: ENTRE DELEUZE E A EDUCAÇÃO. São Paulo: CEDES, 2005.

PENNA, Maura.(org.) É ESTE O ENSINO DE ARTE QUE QUEREMOS? Uma análise das propostas dos Parâmetros Curriculares Nacionais. Editora Universitária: João Pessoa, 2001.

PILLAR, Analice D. (org.). A educação do olhar no ensino das artes. Porto Algre: Mediação, 1999.

RANCIĖRE, Jacques. O Mestre ignorante: cinco lições para a emancipação intelectual. trad. Lilian do Valle. Belo horizonte: Autêntica, 2005.

A partilha do sensível: estética e política. trad. Monica Costa Netto. São Paulo: EXO experimental org., Ed. 34, 2005.

RIBEIRO, Cintya Regina. "Pensamento do fora", conhecimento e pensamento em educação: conversações com Michel Foucault. Educ. Pesqui., São Paulo, v. 37,n. 3,Dec. 2011. Disponível em: $<$ http://www.scielo.br/scielo.php?script=sci_arttext\&pid=S1517-97022011000300011\&lng=e n\&nrm=iso>. Acesso em: 02/03/2015.

SANT'ANNA, Denise Bernuzzi de. Corpos de passagem: ensaios sobre a subjetividade contemporânea. São Paulo: Estação Liberdade, 2001.

SILVA, Tomaz Tadeu. O sujeito da educação. Petrópolis: Vozes, 1994.

Dr. Nietzsche, curriculista: com uma pequena ajuda do professor Deleuze. In: REUNIÃO ANUAL DA ANPED, 24. Programa e resumos. Associação Nacional de Pós-Graduação e 
Pesquisa em Educação, 2001. p.189.

SKLIAR, Carlos. Jacotot-Rancière ou a dissonância inaudita de uma pedagogia (felizmente) pessimista. Educ. Soc., Campinas, v. 24, n. 82,p. 229-239, Abril, 2003. Disponível em: <http://www. scielo.br/scielo.php?script=sci_arttext\&pid=S0101-73302003000100013\&lng=en\&nrm=iso>. access on 14 July 2015. http://dx.doi.org/10.1590/S0101-73302003000100013.

SPINOZA, Benedictus. Ética/Spinoza. trad. Tomaz Tadeu Silva.Belo Horizonte: Autêntica Editora, 2007. VEIGA-NETO, Alfredo (org). Foucault \& a educação. Belo Horizonte: Autêntica, 2003.

VERMEREN, Patrice; CORNU, Laurence; BENVENUTO, Andrea. Atualidade de o mestre ignorante.Revista Educação e Sociedade, v. 24, n. 82, p. 185-202, 2003.

Disponível em: http://www.scielo.br/pdf/es/v24n82/a09v24n82.pdf. Acesso em 14/06/2015.

ZOURABICHVILI, François. O vocabulário de Deleuze. Disponível em: http://claudioulpiano.org. br.s87743.gridserver.com/wp-content/uploads/2010/05/deleuze-vocabulario-francois-zourabichvili1.pdf. Acesso em 03/08/2014.

Revistas, Dissertações de Mestrado e Teses de Doutorado:

BENEDETTI, Sandra. Entre a educação e o plano de pensamento de Deleuze e Guattari: uma vida. 2007. São Paulo: Faculdade de Educação, USP. Tese de Doutorado, 2001.

CAMPOS, A. e H.; PIGNATARI, Décio. Plano-piloto da poesia concreta. 1958. In: www.poesiaconcreta.com. Acesso em 25/05/2013 às 10:38.

COSTA, Gilcilene Dias da. Curricularte: experimentações pós-críticas em educação. Revista Educação e Realidade. Porto Alegre: v.36 2011. Disponível em: http://seer.ufrgs.br/educacaoerealidade/article/view/11554. Acesso em 03/12/2014.

HONORATO, Cayo. A formação do artista: conjunções e disjunções entre arte e educação. 2011. São Paulo: Faculdade de Educação, USP. Tese de Doutorado.

FISCHER, Rosa Maria Bueno. Foucault revoluciona a pesquisa em educação?.Perspectiva, v. 21, n. 2, p. 371-389, 2003.

INFORSATO, Erika Alvarez. Desobramento: constelações clínicas e políticas do comum; Orientação: Prof. Dr. Celso F. Favaretto. São Paulo: FE/USP, 2011. (Tese de Doutorado)

KOHAN, Walter. Entre Deleuze e a educação: notas para uma política do pensamento. Revista Educação e Realidade. Porto Alegre: v.27. ano 2. 2002. Disponível em: http://seer.ufrgs.br/educacaoerealidade/article/view/25922. Acesso em 28/02/2015. p. 124.

KROEF, Ada Beatriz. Currículo-nômade: sobrevôos de bruxas e travessias de piratas. Tese de Doutorado. Porto Alegre: FACED/ UFRGS, 2003.

LOPONTE, Luciana Gruppelli. Docência artista: arte, estética de si e subjetividades femininas. Orientação: Prof. Dra. Rosa Maria Bueno Fischer. Porto Alegre: UFRGS, 2005. (Tese de Doutorado).

Do Nietzsche Trágico ao Foucault Ético: sobre estética da existência e uma ética para docência.In: Revista Educação \& Realidade, v. 28, n. 2, 2003. p. 74.

Arte e estética da docência: conversas com Nietzsche e Foucault. Disponível em: http://www.portalanpedsul.com.br/admin/uploads/2008/Educacao_e_arte/Trabalho/01_39_55_ARTE_E_ESTETICA_DA_DOCENCIA__CONVERSAS_COM_NIETZSCHE_E_FOUCA. pdf. Acesso em 10/06/2015.

MANTERO, Ana. Contraponto. Klee e Kandinsky - Diálogos em terra fértil. Revista Philosophica. Disponível: http://www.centrodefilosofia.com/uploads//pdfs/philosophica/19_20/14.pdf. Acesso em 15/04/2014.

MASET, Pierangelo. Between education and participation: Aesthetic operations. Artigo publicado 
na revista Engage no. 20. 2009. Disponível em: http://www.engage.org/downloads/215025048_ E]_20_P.Maset.pdf. Acesso em 15/07/2014.

MENEZES, Marina Pereira. A arte contemporânea como conteúdo e fundamento para a prática do ensino de artes. Dissertação (Mestrado em Artes), Instituto de Artes, Universidade do Estado do Rio de Janeiro, Rio de Janeiro, 2007.

Ó, Jorge Ramos do; Costa, Marisa. Desafios à Escola Contemporânea: um diálogo. Entrevista concedida à. Revista Educação \& Realidade, v.32, n.2, p.109-116, jul./dez. 2007.

PASCUCCI, Alessio di. Letras Lúdicas. Botucatu: Sociedade dos Amigos da Biblioteca Pública Emílio Pedutti, 2010.

PINHO, Luis Celso, A vida como uma obra de arte: esboço para uma ética foucaultiana. Disponível em: http://www.ufrrj.br/graduacao/prodocencia/publicacoes/etica-alteridade/artigos/Luiz_celso_Pinho.pdf. Acesso em 01/08/2015

Revista Educação. Especial Biblioteca do Professor no 6: Deleuze pensa a educação.

TADEU, Tomaz. A arte do encontro e da composição: Spinoza + Currículo + Deleuze. Revista Educação e Realidade. v.27. n. 2. Porto Alegre: Jul/dez 2002.h Disponível em: http://seer.ufrgs.br/ educacaoerealidade/article/view/25915. Acesso em 20/10/2014.

VASCONCELOS, J. A filosofia e seus intercessores: Deleuze e a não filosofia. In; Revista: Educ. Soc., Campinas, vol. 26, n. 93, p. 1217-1227, Set./Dez. 2005. p. 1219.

Disponível em <http://www.cedes.unicamp.br>. Acesso em 07/07/2015.

WEBER, José F. Bildung e Educação. Educação \& realidade 31.2 (2006). Disponível em: http:// seer.ufrgs.br/educacaoerealidade/article/view/6848. Acesso em 08/03/2015. p.3.

ZORDAN, Paola. Arte com Nietzsche e Deleuze. Revista Educação e Realidade. v.30. Porto Alegre: Jul/dez 2005. Disponível em: http://seer.ufrgs.br/educacaoerealidade/article/view/12472. Acesso em: 20/10/2014.

Percursos das artes visuais: geologia de uma disciplina. Disponível em: http://33reuniao.anped.org.br/33encontro/app/webroot/files/file/Trabalhos\%20em\%20PDF/ GT24-6006--Int.pdf. Acesso em 03/06/2015.

Criação na perspectiva da diferença. Disponível em: http://cascavel.ufsm.br/revistas/ojs-2.2.2/index.php/revislav/article/view/2135/1297. Acesso em: 02/07/2015. 
